\author{
UNIVERSIDADE DE SÃO PAULO \\ FACULDADE DE FILOSOFIA LETRAS E CIÊNCIAS HUMANAS \\ DEPARTAMENTO DE LETRAS ORIENTAIS \\ PROGRAMA DE LITERATURA E CULTURA RUSSA
}

DANIELA SIMONE TEREHOFF MERINO

\title{
Mestre de teatro, mestre de vida - Leopold Sulerjítski e sua busca artística e pedagógica
}

São Paulo 


\title{
Mestre de teatro, mestre de vida - Leopold Sulerjítski e sua busca artística e pedagógica
}

\author{
Daniela Simone Terehoff Merino
}

\begin{abstract}
Dissertação apresentada ao programa de Pósgraduação em Literatura e Cultura Russa, do Departamento de Letras Orientais da Faculdade de Filosofia, Letras e Ciências Humanas da Universidade de São Paulo, para obtenção do título de Mestre em Letras.

Pesquisa desenvolvida com apoio da Fundação de Amparo à Pesquisa do Estado de São Paulo (FAPESP)
\end{abstract}

Orientador: Profa. Dra. Elena Vássina De acordo:

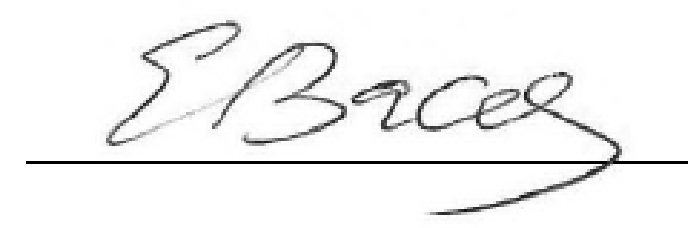

São Paulo 
Autorizo a reprodução e divulgação total ou parcial deste trabalho, por qualquer meio convencional ou eletrônico, para fins de estudo e pesquisa, desde que citada a fonte.

Catalogação na Publicação Serviço de Biblioteca e Documentação

Faculdade de Filosofia, Letras e Ciências Humanas da Universidade de São Paulo

M

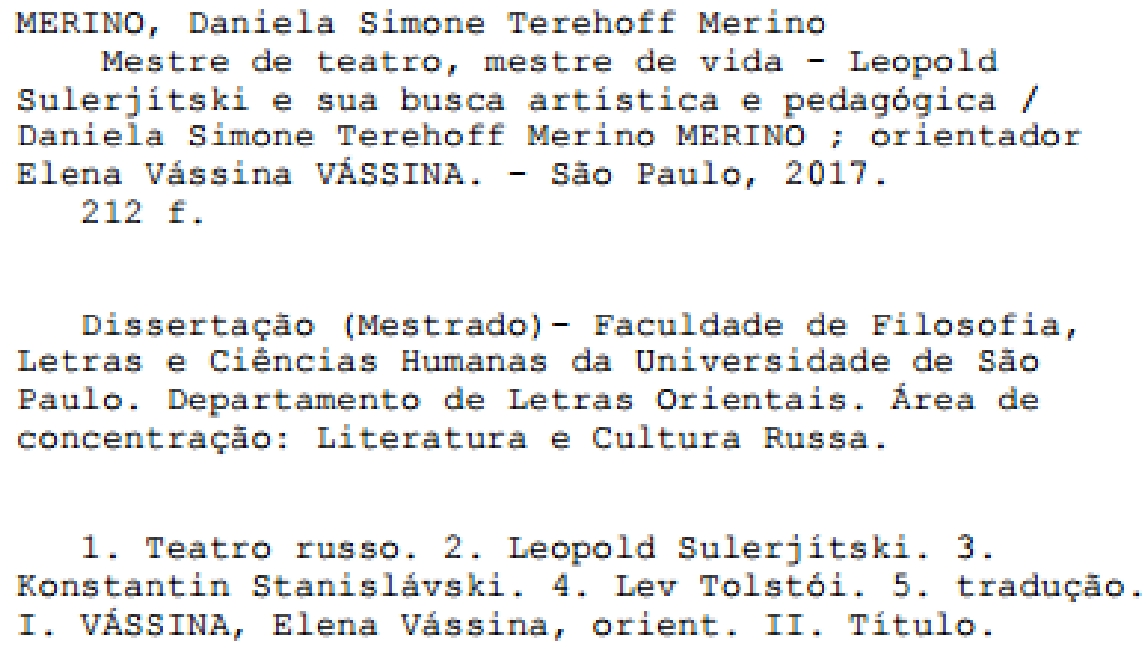


Nome: MERINO, Daniela Simone Terehoff

Título: Mestre de teatro, mestre de vida - Leopold Sulerjítski e sua busca artística e pedagógica

Dissertação apresentada ao programa de Pósgraduação em Literatura e Cultura Russa, do Departamento de Letras Orientais da Faculdade de Filosofia, Letras e Ciências Humanas da Universidade de São Paulo, para obtenção do título de Mestre em Letras.

Aprovado em:

\section{Banca Examinadora}

Prof. Dr. Instituição:

Julgamento: Assinatura:

Prof. Dr. Instituição:

Julgamento: Assinatura:

Prof. Dr. Instituição:

Julgamento: Assinatura: 
Ao meu falecido avô Alexander Terehoff Vediaiev, por servir como inspiração em minha caminhada. 


\section{Agradecimentos}

Agradeço de coração à minha orientadora, Prof. Dra. Elena. Vássina, pela confiança e incentivo desde o início de minha graduação em Língua Russa, bem como pela excelente orientação no decorrer desta pesquisa.

À FAPESP, pela concessão da bolsa de mestrado no país, processo no 2014/09080-0, e da bolsa BEPE no exterior, processo no 2015/24015-2, Fundação de Amparo à Pesquisa do Estado de São Paulo (FAPESP), sem as quais esta dissertação jamais existiria.

Aos professores integrantes da banca de qualificação e de defesa, prof. Dr. Noé Silva e profa. Dra. Nair D'Agostini, por seus valiosos conselhos e apontamentos e por terem recebido esta pesquisa com tanto carinho.

Aos professores Dr. Vadim Scherbakov e Dr. Vladislav Ivánov do Instituto Estatal de Pesquisa de Arte, pela ótima recepção que tive em Moscou durante a BEPE.

A toda a minha família. Em especial à minha mãe Olga Terehoff Gonzalez e meu pai Juan Claudio Merino Rodriguez, que sempre me apoiaram e torceram tanto para a realização de meus sonhos

Ao meu marido Leandro Albino, sem o qual este trabalho jamais teria se concretizado.

Às minhas irmãs Carolina Terehoff Merino e Claudia Andréia Terehoff Merino, por seus conselhos e apoio constante. Por serem mais do que irmãs., me aconselharem e ajudarem todas as vezes que estive com alguma dificuldade em meu trabalho.

Aos meus tios, Alejandro, Natalia e Tamara, que sempre acreditaram em mim e me apoiaram durante o desenvolvimento desta pesquisa.

Ao meu avô Juan pela torcida.

Ao meu amigo Gregori Taki, pela paciência e por todo o auxílio prestado durante minha estadia em Moscou.

A todos os meus professores da pós-graduação. Em especial à professora Dra. Maria Thais Lima Santos e ao professor Dr. João Azenha Junior que deram excelentes orientações no decorrer de minha pesquisa.

Aos meus professores de teatro, sem os quais eu certamente não sentiria hoje o mesmo amor pela arte.

Em especial Isabella Veiga, Robson Scobar, Luana Alves e Emerson Ribeiro, que sempre me inspiraram.

Ao meu amigo e grande artista Romário Oliveira, por estar sempre ao meu lado.

A Rafael e Marli, meus tios de consideração, por sempre torcerem por mim. 
À família Godoy Gomes - Paulo, Irene, Guilherme e Vinicius - , por acreditarem que isto seria possível e nunca me deixarem desanimar.

Ao meu amigo Rennan Lopes, por me ajudar sempre que foi preciso.

Ao amigo Carlos, por seu apoio e diversas dicas na reta final de minha pesquisa.

A Denilson Oliveira, pelo auxilio prestado na etapa final e revisão deste trabalho.

A Sérgio, da gráfica Casa das Teses, sem o qual eu não teria conseguido entregar meu trabalho dentro do prazo estabelecido.

A todos aqueles que participaram desta pesquisa direta ou indiretamente, os meus mais sinceros agradecimentos. 


\section{RESUMO}

MERINO, D. S. T. Mestre de teatro, mestre de vida - Leopold Sulerjítski e sua busca artística e pedagógica. 2016. Dissertação (Mestrado) - Faculdade de Filosofia, Letras e Ciências Humanas, Universidade de São Paulo, São Paulo, 2016.

O presente trabalho aborda a herança artística, literária e pedagógica e a tradução diretamente do russo de cartas, trechos de diários e ensaios de Leopold Antônovich Sulerjítski (1872-1916), um dos maiores mestres teatrais e pedagógicos do início do século XX. Artista, pedagogo, literato e diretor de cena profundamente ligado à vida artística e cultural de sua época, Leopold Sulerjítski participou intensamente das atividades do Primeiro Estúdio do Teatro de Arte de Moscou, tornando-se o responsável pela propagação de elementos de tendência tolstoiana entre os atores que guiava. Além de abordar a influência exercida pelo escritor Lev Tolstói (1828-1910) dentro do Primeiro Estúdio via Leopold Sulerjítski, nosso estudo aprofunda o entendimento do papel fundamental que o diretor exerceu na formação do Sistema de Konstantin Stanislávski (1863-1938), sua incessante busca pela interligação entre estética e ética filosófica, e a conexão existente a partir de então entre pedagogia e criação, essencial até hoje à função do diretor teatral. Partindo do estudo da grande massa crítica e teórica de importantes teatrólogos russos como Pavel Márkov, Konstantin Rudniíski e sobretudo Elena Poliakova, ainda inéditos em português, visa-se introduzir as abordagens teóricas russas do papel desempenhado por Sulerjítski na vida cultural da Rússia do início do século XX.

Palavras chave: Teatro russo; Leopold Sulerjítski; Lev Tolstói; Konstantin Stanislávski; Tradução 


\begin{abstract}
MERINO, D. S. T. Theatre master, life master - Leopold Sulerzhitsky and his artistic and pedagogical experience. 2016. Dissertação (Mestrado) - Faculdade de Filosofia, Letras e Ciências Humanas, Universidade de São Paulo, São Paulo,
\end{abstract}

The present work deals with the artistic, literary and pedagogical heritage and the Russian translation of letters, excerpts from the diaries and essays by Leopold Antônovich Sulerzhitsky (1872-1916), one of the greatest theatrical and pedagogical masters of the early twentieth century. Leopold Sulerzhitsky, an artist, educator, lithographer and director deeply connected to the artistic and cultural life of his time, participated intensively in the activities of the First Studio of the Moscow Art Theater, becoming responsible for the propagation of elements of Tolstoy tendency among the Actors he led. In addition to addressing the influence exerted by the writer Liev Tolstoy (1828-1910) within the First Studio via Leopold Sulerzhitsky, our study deepens the understanding of the fundamental role the director played in the formation of Konstantin Stanislavski's System (1863-1938), his incessant Search for the interconnection between aesthetics and philosophical ethics, and the connection that existed between pedagogy and creation, essential until now to the function of the theatrical director. Based on the study of the great critical and theoretical mass of important Russian theatologists such as Pavel Márkov, Konstantin Rudnitsky and above all Elena Poliakova, still unpublished in Portuguese, the aim is to introduce Russian theoretical approaches to the role played by Sulerzhitsky in the cultural life of Russia from the beginning of the Century.

Keywords: Russian Theater; Leopold Sulerzhitsky ; Lev Tolstoy; Konstantin Stanislavski; Translation. 


\section{CAPÍTULO 1 - LEOPOLD SULERJÍTSKI - DIRETOR REDESCOBERTO} .15

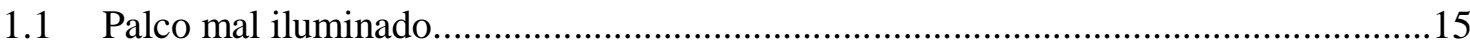

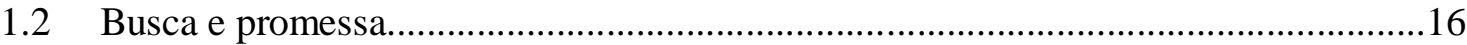

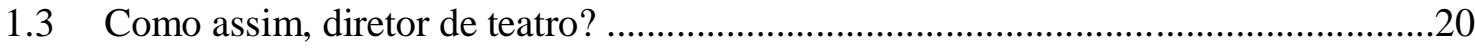

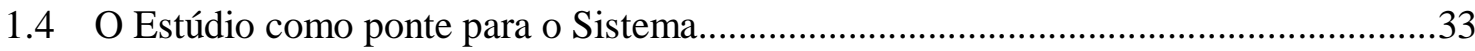

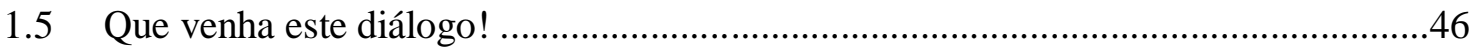

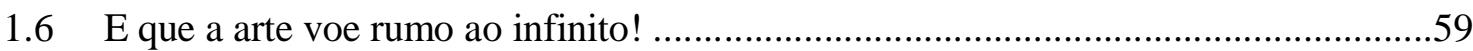

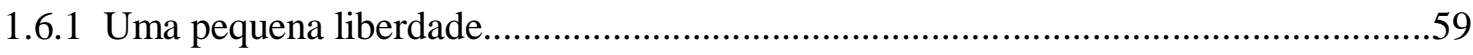

1.6.2 Da relação entre Ética e Estética dentro do Estúdio..................................................60

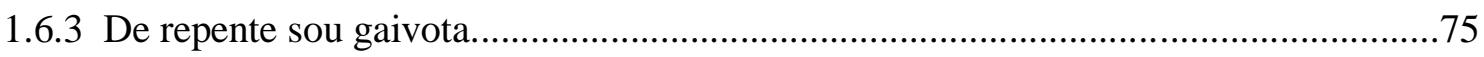

CAPÍTULO 2 - LEOPOLD SULERJÍTSKI - HOMEM DE SEU TEMPO...................76

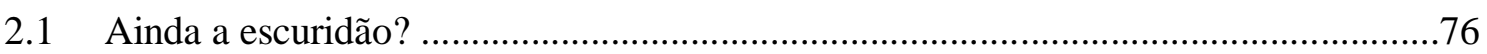

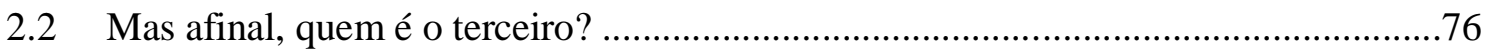

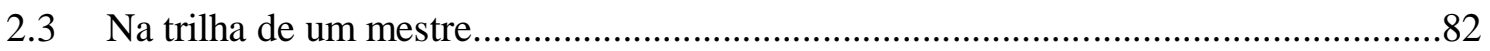

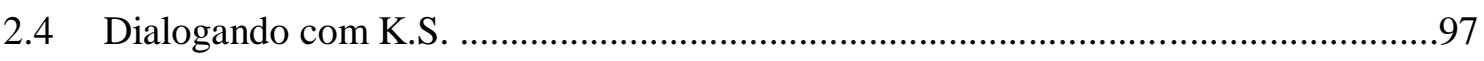

CAPÍTULO 3 - LEOPOLD SULERJÍTSKI - OLHAR PEDAGÓGICO....................106

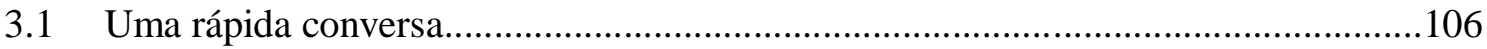

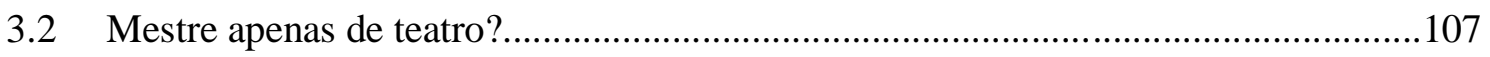

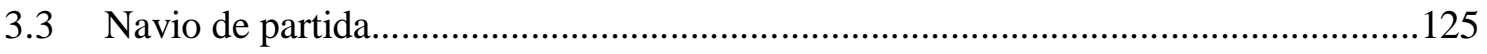

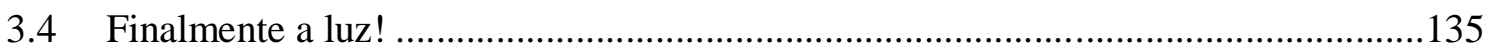

CONCLUSÃO

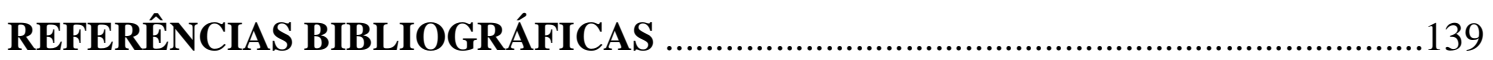

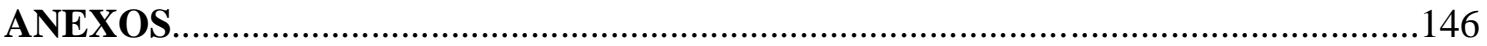




\section{INTRODUÇÃO}

Leopold Antônovich Sulerjítski (1872-1916) foi um dos maiores mestres teatrais e pedagógicos do início do século XX. Além de contribuir imensamente para a divulgação do Sistema ${ }^{1}$ de Konstantin Stanislávski (1863-1938) e auxiliar na criação do Primeiro Estúdio do Teatro de Arte de Moscou (TAM), Sulerjítski foi um dos principais responsáveis pelo desenvolvimento e sistematização de uma pedagogia da formação do ator. Em sua constante busca por relações humanas mais profundas dentro da arte, este diretor e pedagogo enxergou no Primeiro Estúdio um espaço onde os atores podiam se transformar, evoluir como seres humanos e a partir daí, transformar também a plateia que tinham diante de si.

A dissertação "Mestre de vida, mestre de teatro - Leopold Sulerjítski e sua busca artística e pedagógica" nasceu da vontade de trazer à tona a voz desta personalidade russa até hoje pouquíssimo conhecida e divulgada no Brasil. Após a realização das disciplinas de Teatro Russo I e II durante a graduação - sob a coordenação da Professora Dra. Arlete Orlando Cavaliere - e após dois anos de Iniciação Científica com bolsa RUSP - sob a orientação da professora Dra. Elena Vássina - na área de literatura, cultura russa e tradução, este trabalho surgiu como uma resposta à necessidade de dar continuidade a uma trajetória marcada pela vontade de introduzir materiais russos inéditos e de riqueza incalculável em nosso país.

A sugestão do tema desta pesquisa foi dada pela professora Elena Vássina em fins de 2013. A partir da leitura da dissertação de mestrado de Camilo Scandolara Os estúdios do Teatro de Arte de Moscou e a formação da pedagogia teatral no século XX e a constatação da importância dos trabalhos de Leopold Sulerjítski para o desenvolvimento da pedagogia teatral e do mundialmente conhecido Sistema de Stanislávski, decidi embarcar nesta busca por materiais ligados a esta personalidade marcante que esteve envolvida não apenas com o teatro, mas também com uma série de outras questões como menciona Stanislávski ao recordá-lo: "Por trás dos bastidores do teatro puseram-se a falar intensivamente sobre Súler²: 'Querido Súler!', ‘Alegre Súler!', 'Súler revolucionário, tolstoísta, dukhobor'. 'Súler romancista, cantor, artista'. 'Súler capitão, pescador, vagabundo, americano!"” (STANISLÁVSKI, 1970, p.546. Tradução nossa)

\footnotetext{
${ }^{1} \mathrm{O}$ "Sistema" de Stanislávski é conhecido e divulgado até hoje por ser um meio de treinamento para o ator, um "guia" que facilita a comunicação expressiva e o trabalho criativo.

${ }^{2}$ Diminutivo de Sulerjítski, uma maneira carinhosa de trata-lo.
} 
Empreender um trabalho de tradução da herança artística, literária e pedagógica de Leopold Sulerjítski é trazer para a língua portuguesa pela primeira vez algumas das facetas ainda desconhecidas de um diretor que ajudou a transformar o teatro russo no início do século XX e que, ao trabalhar na divulgação do Sistema, influenciou de alguma maneira - ainda que velada - o teatro que vemos atualmente; é trazer a voz de um homem que conviveu com Lev Tolstói e por esta razão, levou aos atores do Estúdio os princípios de amor, bondade, igualdade e união que faziam parte das ideias fundamentais do escritor russo.

Cartas, diários e ensaios constituem, neste sentido, material extremamente rico, por meio do qual é possível entrar em contato com os mais variados sentimentos e pensamentos desta personalidade multifacetada e atuante que foi Leopold Sulerjítski. A partir de suas obras completas, presentes em antologia organizada e prefaciada em 1970 pela teatróloga russa Elena Poliakova, verificou-se o quanto a tradução destes materiais poderia auxiliar no alcance dos principais objetivos específicos propostos no início desta pesquisa, a saber: 1) situar Leopold Sulerjítski no contexto sócio-histórico e cultural de sua época; 2) revelar o papel que Sulerjítski desempenhou na formação dos princípios éticos e estéticos do TAM e do Primeiro Estúdio do TAM; 3) pesquisar a influência que as ideias e a personalidade de Lev Tolstói exerceram sobre Leopold Sulerjítski; e, por fim, 4) desvendar os pensamentos de Sulerjítski no que diz respeito à pedagogia teatral.

Mas se com a coletânea de Poliakova - atualmente disponível na internet - , a presente pesquisa já tinha bons materiais em que se basear, foi apenas com a bolsa BEPE e o acesso aos arquivos de Leopold Sulerjítski conservados em Moscou que o trabalho atingiu sua completude. A bolsa no exterior, concedida pela FAPESP durante o período de três meses no início de 2016, permitiu que trabalhássemos com materiais ainda não publicados nem mesmo em russo. Estes materiais abriram espaço para novos olhares, ampliando e dando maior peso à nossa pesquisa.

Os arquivos de Moscou foram devidamente selecionados, traduzidos e dispostos ao longo desta dissertação de acordo com sua conveniência. O mesmo procedimento se deu com as cartas e recordações de alunos e amigos presentes na coletânea de Poliakova, dos quais optamos por incluir apenas os trechos mais significativos conforme a necessidade do que é dito em cada capítulo. Quanto aos textos Sobre as relações entre ator e diretor (1909) e Dos diários (1913-1914), foram traduzidos na íntegra e ambas as traduções apresentam- 
se em anexo no final deste trabalho. Tal opção pelas traduções na íntegra deveu-se a alguns fatores cruciais, os quais serão expostos a seguir.

Em primeiro lugar, o ensaio Sobre as relações entre ator e diretor (1909)trata de resposta a uma das grandes questões presentes no teatro do início do século XX: o embate entre o teatro de natureza emocional de Stanislávski e o teatro de convenção do diretor russo Vsévolod Meyerhold (1874-1940). Tal ensaio, portanto, insere Sulerjítski nesta pesquisa como um homem de seu tempo, atento não apenas às pequenas coisas do cotidiano, como também àquelas que geravam grandes debates, exigindo uma ou outra postura de seus contemporâneos.

De acordo com Bakhtin:

(...) todo falante é por si mesmo um respondente em maior ou menor grau: porque ele não é o primeiro falante, o primeiro a ter violado o eterno silêncio do universo, e pressupõe não só a existência do Sistema da língua que usa, mas também de alguns enunciados antecedentes - dos seus e alheios - com os quais o seu enunciado entra nessas ou naquelas relações (baseia-se neles, polemiza com eles, simplesmente os pressupõe já conhecidos do ouvinte). Cada enunciado é um elo na corrente complexamente organizada de outros enunciados. (BAKHTIN, 2011, p.272)

Já com relação à tradução de seus diários foram observados três aspectos fundamentais.

O primeiro deles refere-se à questão temporal e à possibilidade, através da leitura de diários, de nos aproximarmos o mais fielmente possível da realidade vivida por aquele que os escreve. Pois não estamos diante da rememoração de um passado longínquo como no caso de uma autobiografia, mas de vivências recentes, do hoje, do ontem.

De acordo com o estudioso da Washington University Manuel Hierro, o tempo presente é o dispositivo central que marca e rege a escritura de um diário. É através do diário íntimo que temos acesso ao mundo tal como o enxergava o escritor, acesso a um diálogo no qual “o 'eu' começa a pertencer ao seu mundo que, por sua vez, revela a experiência subjetiva.”(HIERRO, 1999, p.115) [Tradução nossa] $]^{3}$ Além disso:

Com todas as suas ambiguidades, o cosmos pessoal do escritor/a de diários íntimos, flutuando entre a experiência temporal do dia a dia, é anotado no diário em um ato de escrita - e de consciência

\footnotetext{
${ }^{3}$ Os trechos por nós traduzidos e incluídos neste trabalho vem acompanhados de seus equivalentes na língua original (inglês, russo ou espanhol), conforme exige a norma acadêmica. Mas devido à extensão de vários dos textos traduzidos optou-se por incluir todos os originais não como nota de rodapé no decorrer da dissertação, mas como anexo no final do trabalho.
} 
de si mesmo - através do qual ele nos comunica e põe em contato com seu mundo. Um mundo em que também estão presentes os outros (...) (HIERRO, 1999, p.105) [Tradução nossa]

Em segundo lugar, a tradução dos diários de Leopold Sulerjítski contribui para melhor entendermos sua personalidade, uma vez que nestas suas anotações não há apenas o registro de atividades e planos cotidianos, mas, sobretudo, reflexões e pensamentos acerca do homem, da vida e da arte, além de outras questões de caráter profundo e revelador.

Por fim, a escolha por este material deu-se tendo em vista que as seis únicas datas de diário que nos restaram de tudo o que escreveu Leopold Sulerjítski, encontram-se totalmente relacionadas ao seu trabalho no Estúdio do Teatro de Arte de Moscou e ao diálogo que travou com Konstantin Stanislávski.

Optar pela tradução das cartas, inseridas consideravelmente no decorrer da dissertação foi outra maneira de termos acesso ao contexto social e cultural da época. Ao vincularem tempo, memória e sujeito, as cartas integram, assim como os diários, a chamada literatura testemunhal e são consideradas material de grande riqueza, pois além de servirem como documento histórico e muitas vezes possuírem função poética, “(...) constituem fragmentos valiosos que refletem a personalidade do seu autor, o seu ambiente e as circunstâncias que envolveram seu trabalho criativo (...)" (ANGELIDES, p.13-14)

O gênero epistolar conta com a diversidade como um de seus grandes pontos característicos. E portanto, ao entrarmos em contato com as cartas temos acesso a

(...) uma mistura de tudo: relato de acontecimentos, espaço de reflexão, testemunho de uma época, registro do nascimento de uma idéia, de um projeto, momento de desabafo, confissão. O espaço epistolar comporta o âmbito do grande e do pequeno, miudezas do cotidiano misturam-se facilmente às grandes reflexões sem que isso nos cause espanto. (...) (TAKEDA, 2003, p.29)

Ao trazer estas traduções pela primeira vez para nossa língua, pretendemos divulgar mais amplamente a importância que Leopold Sulerjítski e o Primeiro Estúdio tiveram para o desenvolvimento da pedagogia teatral e de sua indissociabilidade em relação ao ato criativo. Ao mesmo tempo, visamos corroborar para o estudo de materiais acerca de Stanislávski e Tolstói já disponíveis em português. 
Aliando estas traduções ao estudo de importantes pesquisas realizadas por teatrólogos russos como Pavel Márkov, Konstantin Rudnítski e Elena Poliakova - ainda inéditos em português - , buscamos introduzir ao máximo as abordagens teóricas russas do papel desempenhado por Sulerjítski na vida cultural da Rússia do início do século XX, disponibilizando em português os seus trechos mais significativos. Ao fazer isso, acreditamos trazer à tona não apenas as principais questões desenvolvidas por estes estudiosos russos, mas também, o verdadeiro valor do papel desempenhado por Leopold Sulerjítski como artista, pedagogo e ser humano. 


\section{CAPÍTULO 1 LEOPOLD SULERJÍTSKI -DIRETOR REDESCOBERTO}

\subsection{Palco mal iluminado}

O público está eufórico. Que veremos esta noite?

Apagam-se as luzes. Abrem-se as cortinas. Faz-se o esperado silêncio.

É quando entra um homem alto, magro e de finos bigodes. Sorri, mas seu sorriso é diferente dos outros. A expressão de seriedade, um ar de quem não está lá para brincar. Muito elegante e com um olhar que reflete algo novo.

Há apenas uma cadeira em cena. Ele vai até ela e ocupa seu espaço. Todos da plateia silenciam. É outra a atmosfera a pulsar agora naquela sala a partir daí. Como se este novo ator, diferentemente daqueles vistos até então, tivesse uma técnica especial até mesmo para se sentar! É possível?

Alguns já sabem de quem se trata: "É Konstantin Stanislávski".” , “Aí está o grande diretor russo do século XX.", “Como? Nunca ouviu falar?!”, "Este sim que é ator!”, "Silêncio! Vocês não sabem que ele gosta de uma plateia silenciosa?" Outras vozes, em maior quantidade, param de rir e reclamam: "Onde estão as risadas? Onde está o entretenimento", "Esse cara estragou a diversão!”.

Surge outro homem em vestes elegantes. Um pouco mais baixo que o primeiro. Cumprimentam-se. Vozes assopram seu nome: é Nemiróvitch- Dantchenko. Conversam baixinho. Fazem anotações. Falam de um teatro acessível a todos. E de repente, como que por mágica, entra em cena um novo teatro. Atores em vestes majestosas. Um cenário esplêndido. Ouve-se uma voz distante: "Que entre Czar

Fiódor". É maravilhoso. O público vai ao êxtase.

Mas como num sonho onde os fatos se sucedem e se interpenetram sem um sentido lógico, de repente estamos diante de uma jovem de preto, a qual diz estar de luto pela vida. Uma gaivota passa voando pelo palco. Atiram nela, apenas pelo prazer de matá-la.

\footnotetext{
4 Konstantin Stanislávski (1863-1938): grande ator e diretor russo. Sua união com Vladimir NemiróvitchDântchenko (1858-1943) e a criação conjunta do Teatro de Arte de Moscou Acessível a todos - posteriormente apenas Teatro de Arte de Moscou (TAM) - abalaram as bases do teatro de seu tempo, trazendo inovações como o senso de missão inalterado, a disciplina constante nos ensaios e a ideia de um verdadeiro ensemble, sem estrelas. Mais tarde, Konstantin Stanislávski se tornaria um dos grandes reformadores do teatro também através da criação de seu Sistema, conhecido e divulgado hodiernamente por ser um meio de treinamento para o ator, um "guia" que facilita a comunicação expressiva e o trabalho criativo.
} 
Fala-se de algo novo: a busca por novas formas. Mas fala-se de um jeito novo também. Um jeito agradável. Os diálogos são precisos. Os corpos dos atores não estão em cena à toa. O que há de diferente? Mais sentimento, talvez? Explosão de sensações. Soa um tiro. O público vai à loucura. Aplaudem. Nunca havíamos visto algo assim até então.

Aquele mesmo ator volta para a cena. Aplaudem-no ininterruptamente.

Senta-se outra vez. Fala sobre suas novas ideias. Repete a palavra "Sistema" e parece incompreendido por todos. Os atores dão as costas a ele. E deixam o palco vazio, um a um.

Apenas um homem vestido com um blusão de marinheiro permanece ao seu lado. Ele diz algo muito importante. Algo sobre coração e união. Mas o palco está mal iluminado e eu não consigo ver seu rosto ou ouvir sua voz. Ninguém consegue. Não sabem dizer qual o seu nome. De onde veio. O que deseja.

Afinal, quem é este homem?

\subsection{Busca e promessa}

Minha professora de russo Elena Vássina me indicou uma leitura nova. Era uma dissertação de mestrado intitulada "Os Estúdios do Teatro de Arte de Moscou e a formação da pedagogia teatral no século XX" (2006). O porquê de aquele material ter vindo parar em minhas mãos eu não soube de imediato. Mas foi aí, pela primeira vez, que pude compreender até certo ponto quem foi aquele homem que dividiu momentaneamente o palco da vida de Stanislávski sem ser iluminado. Chamava-se Leopold Antônovitch Sulerjítski. ${ }^{5}$

Mas então quer dizer que Konstantin Stanislávski não criou e nem aplicou seu Sistema absolutamente sozinho? E que o Primeiro Estúdio do TAM, aberto em 1912, foi desenvolvido em grande medida devido à existência de Leopold Sulerjítski?

Pois é. Às vezes a falta de luz cega a plateia.

Com esta dissertação de mestrado que eu tinha em mãos, enfim o tal homem desconhecido saía das sombras de um palco mal iluminado para ganhar um pouco de

\footnotetext{
${ }^{5}$ Leopold Antônovich Sulerjítski, batizado na igreja católica com o nome de Lev-Leopold-Maria nasceu em Jítomir, na Rússia, em 15 de novembro (27 de novembro) de 1872. Morre aos 44 anos em 17 (29) de dezembro de 1916. As datas aparecem aqui duas vezes, pois a cultura russa adotou o calendário gregoriano apenas em 1918, e por isso é de praxe que as datas históricas anteriores venham escritas de duas maneiras: primeiro de acordo com o calendário antigo (juliano) e entre parênteses, em seguida, de acordo com o atual (gregoriano). A diferença entre os dois consta de 13 dias.
} 
visibilidade em nosso país e aparecer como um artista e pedagogo digno de iluminação. Ainda que sua aparição em cena durasse apenas o tempo de leitura das cinquenta e duas páginas em que Sulerjítski era o foco central desta dissertação escrita por Camilo Scandolara.

Mas não sejamos injustos. Que eu não conhecesse nada sobre Leopold Sulerjítski até então, não significa que nada houvesse sido dito ou chegado até nós em língua portuguesa. Estudiosos renomados como Jacó Guinsburg, Ângelo Maria Ripellino e Marc Slonim já haviam dedicado anteriormente uma parte - bastante modesta - de seus trabalhos ao estudo deste diretor e pedagogo, apresentando-o em geral com as mesmas características: um homem que deseja unir a todos por meio da arte, é contra a histeria no teatro, ajuda na propagação do Sistema dentro do Primeiro Estúdio do Teatro de Arte de Moscou e, principalmente, faz parte dos discípulos do escritor russo Lev Tolstói (18281910).

Fui atrás destes materiais. Mas não pude ouvir a voz de Sulerjítski.

Sua voz...Onde estava ela?

Uma das novidades da dissertação de Scandolara é que pela primeira vez pudemos ler em português uma parte daquilo que Leopold Sulerjítski dizia e escrevia. As traduções vinham do italiano, e não do original russo. Mas ainda assim, refletiam suas palavras, seu pensamento. Mas será que era o suficiente?

Ainda hoje, toda vez que digo o nome de Leopold Sulerjítski - do "querido Súler", como o chamavam carinhosamente seus amigos e conhecidos -, mesmo entre estudiosos de teatro é raro alguém saber de quem se trata. Seu nome nem de longe tem aqui no Brasil a mesma força que o de Vsevolod Meyerhold ou o de Konstantin Stanislávski. Sem contar o fato de já termos disponíveis em português os livros A arte do ator e Para o ator, escritos respectivamente por Richard Boleslávski e Mikhail Tchekhov, dois dos alunos de Leopold Sulerjítski no Primeiro Estúdio. Os alunos ganharam destaque, o professor ficou esquecido. E com isso só deixamos de aprender.

Com esta consciência decidi suprir esta lacuna de alguma forma. Se eu podia ir até a fonte, ler Sulerjítski e ao mesmo tempo consultar aquilo que os próprios russos dizem a seu respeito, para somente a partir disso trazer novos materiais para o Brasil, por que não o fazer? Uma dissertação de mestrado que incluísse uma parte da herança artística e pedagógica desta figura seria uma boa maneira de começar a introduzir o nome de Leopold Sulerjítski definitivamente no Brasil. 
Na Rússia isso já foi feito e até hoje vem deixando rastros. Importantes teatrólogos russos do século XX, tais como Pavel Márkov e Konstantin Rudnítski foram fundamentais para que Sulerjítski ocupasse o espaço que tem atualmente. O livro Russkoie rejisserskoie iskustvo: 1908-1917 (A arte de direção russa: 1908-1917) (1990), do teatrólogo e historiador Rudnítski inclui Leopold Sulerjítski na história do teatro russo como um homem que lutou até o fim da vida pelo aperfeiçoamento moral e a permanência de princípios éticos entre os alunos. Cada detalhe do Estúdio, das encenações feitas ao tratamento dado aos funcionários, merecia a sua atenção. E é significativo que ele seja apontado por Rudnítski como alguém que deu um sentido mais universal para o Sistema, distinguindo-se aqui de Stanislávski. A partir desta observação de Rudnítski, nosso estudo ganha uma nova direção, visto que Leopold Sulerjítski deixa de ser apenas um seguidor de Stanislávski, para tornar-se também ele um defensor de suas próprias ideias.

Pavel Márkov dedica todo um capítulo de seu livro O teatre (Sobre o teatro) (1974) para tratar do Primeiro Estúdio e de três importantes figuras que dele fizeram parte: Leopold Sulerjítski, Evguêni Vakthângov e Mikhail Tchekhov. A vida artística dos três esteve profundamente interligada e tanto Vakhtângov quanto Tchekhov, herdeiros e seguidores de Leopold Sulerjítski, escreverão a este respeito posteriormente. Mas o que marca profundamente o estudo feito por Márkov é o fato de ele destacar Sulerjítski como o autêntico diretor e inspirador do Estúdio, em sua opinião, até mais do que Stanislávski. Márkov se detém sobre vários aspectos da vida e do trabalho de Sulejrjítski no Primeiro Estúdio do TAM, sobre as peças que ele dirigiu ao lado de seus alunos, sobre seu repúdio à histeria e, por fim, sua função de mestre e guia dos atores do Estúdio, seus ideais profundos e a grande força moral que fizeram dele "Em igual medida um professor da vida e da cena. Aliás, mais professor da vida do que da cena." (MÁRKOV, 1974) [Tradução nossa]

Se Pavel Márkov e Konstantin Rudnítski merecem destaque em nosso trabalho, o que falar então da teatróloga russa Elena Poliakova? Foi graças a ela que Leopold Sulerjitski conquistou definitivamente o seu espaço. Elena Poliakova publicou duas obras com foco absoluto sobre Sulerjítski - uma em $1970^{6}$ e a outra em $2006^{7}$-, e em ambas

\footnotetext{
${ }^{6}$ Sulerjitski L. A. Povesti i rasskazy. Stati i zametki o teatre. Perepiska. Vospominania o L. A. Sulerjítskom. (Sulerjítski L. A. Novelas e contos. Artigos e observações sobre o teatro. Correspondência. Recordações sobre L. A. Sulerjítski)

${ }^{7}$ Teatr Sulerjitskovo: Etika. Estetica. Rejissura. (O teatro de Sulerjítski: Etica. Estética. Direção).
} 
fornece um panorama completo da vida do diretor russo. Sobretudo em sua primeira obra, na qual nos deparamos não só com o estudo feito pela teatróloga, como também, e principalmente, com os artigos sobre teatro escritos por Leopold Sulerjítski, as correspondências trocadas com grandes personalidades da época, trechos de diário e depoimentos deixados por ex-alunos, os quais serão incluídos na medida do possível nesta dissertação. Quanto ao livro de 2006, são nele abarcados todos os aspectos da vida de Leopold Sulerjítski, servindo de complemento à sua obra anterior e desempenhando papel significativo em nosso trabalho.

Mas toda esta busca por obras de grandes estudiosos russos pode ser ainda mais profunda se levarmos em conta os materiais disponíveis atualmente em Moscou, tais como os arquivos guardados pelo Museu do Teatro de Arte de Moscou (TAM).

Quando estive na Rússia no início deste ano com bolsa BEPE da FAPESP, foi com prazer que pude observar o quanto Leopold Sulerjítski ainda faz parte da vida teatral da Rússia atualmente. Até hoje a peça $O$ pássaro azul é apresentada com a mesma montagem que Sulerjítski e Stanislávski elaboraram para ela em 1905. Ainda hoje os guias da excursão pelo museu-apartamento de Vakthângov mencionam Leopold Sulerjítski como um homem excepcional, sem o qual o ator e diretor Evguênie Vakthângov não teria existido. Sem contar sua grande fotografia neste museu; bem como uma fotografia de tamanho similar em uma das paredes do próprio Teatro de Arte de Moscou (TAM), na mesma sala onde se encontram as fotos de grandes figuras também ligadas ao teatro, tais como Lev Tolstói, Máximo Górki, Anton Tchekhov e Gordon Craig. Há livros e artigos de revista atuais sobre Sulerjítski disponíveis nas principais bibliotecas da capital russa; cartas e cadernos de anotações são conservados atualmente no Museu do TAM; e em Maio, quando toda a cidade é decorada pela chegada da Primavera e a praça central se enche de árvores com fotos de diretores e espetáculos de teatro importantes para a Rússia, Leopold Sulerjítski também tem direito à mais de uma foto pendurada nestas árvores ${ }^{8}$.

Durante o período de três meses que estive em Moscou, conversei com os professores Dr. Vadim Scherbakov e Dr. Vladislav Ivánov, do Instituto Estatal de Pesquisa de Arte, e pude entender melhor qual o papel ocupado por Leopold Sulerjítski atualmente na Rússia. Realizei também uma busca pelos arquivos e graças ao auxílio do pesquisador Gregori

\footnotetext{
${ }^{8}$ Ver fotos em anexo, nas quais incluo parte de minha experiência durante a estadia em Moscou e alguns dos mais significativos materiais citados neste parágrafo.
} 
Taki, que participou comigo da aventura de decifrar o que estava escrito nos cadernos de anotação de Leopold Sulerjítski, será possível incluir neste trabalho a tradução de materiais absolutamente inéditos.

Mas, é óbvio, também na Rússia muitas pessoas ainda não sabem quem foi Leopold Sulerjítski. No penúltimo dia da viagem resolvi visitar o túmulo do diretor no cemitério Novodévitchi onde estão enterrados juntos todos os grandes artistas russos. Perguntei a um guarda do local se sabia onde estava o túmulo de Sulerjítski. “Quem?” Realmente ele não fazia a menor ideia. Perguntei então sobre Stanislávski, perto de quem naturalmente Sulerjítski estaria. Ele me levou imediatamente ao local.

Demos algumas voltas, procurando por seu nome. Mas o guarda não sabia onde estava Sulerjítski. E me indicou mais de uma vez outros nomes ali presentes: "Olha, ali está Tchekhov.", "Bulgákov...." e "Veja...Górki. Você não quer ver Górki?”. Entrementes, o guarda repetia baixinho o nome de "Sulerjítski”, sem conseguir encontrálo. Acabou indo embora e eu tive de procurar pelo "querido Suler". Sozinha.

Quando o encontrei, em meio ao silêncio daquele local - um pequeno mundo apartado de tudo, onde a arte pulsa debaixo da terra -, permaneci calada por alguns segundos. O que dizer? Eu não o havia conhecido. Não sabia como fora sua voz, seu riso, como era essa sua alegria de que falam tanto os depoimentos de ex-alunos seus. Mas sabia que suas ideias me faziam bem. Que seus escritos me ensinavam a viver melhor. E gostaria que isso fizesse parte da vida de meus contemporâneos também.

"Eu sei que você nem sabe quem sou eu. Mas eu prometo. Que o que eu puder levar das suas ideias para o Brasil, eu vou levar. Eu quero poder falar seu nome e ser entendida. Não quero mais ver a mesma boca se torcendo outra vez por não saberem que você existiu. E quem você foi."

No dia seguinte, o Brasil outra vez. Os estudos outra vez. A vida voltando aos eixos.

Mas uma promessa assim muda tudo.

Que ela se cumpra por meio desta dissertação!

\subsection{Como assim, diretor de teatro?}

Se você abrir qualquer um dos livros de Elena Poliakova, vai perceber que esta pergunta não é à toa. 
Leopold Sulejítski é apresentado em seus livros como um homem cuja vida esteve permeada pela realização das mais variegadas atividades. Ora ofícios artísticos como a pintura, o canto, a dança e a escrita, ora ofícios que nada têm a ver com o mundo das artes, tais como o trabalho de camponês ou de marinheiro. A partir de 1894 trabalhou como copista de Lev Tolstói; em 1895 foi preso depois de renunciar ao serviço militar ${ }^{9} ; 3$ anos depois auxiliou Lev Tolstói na transferência da seita dos dukhobors ${ }^{10}$ para o Canadá. E a partir de 1901, tendo se envolvido com o Partido Social Democrata e com a divulgação de escritos proibidos pelo governo foi deportado juntamente com sua esposa Olga Sulerjítskaia para a fortaleza turco-russa de Kushka, na fronteira com o Afeganistão, onde ambos permaneceram até $1903 .^{11}$

Mas nenhum destes acontecimentos impediu que seu amor pela arte crescesse cada vez mais. Um amor que veio desde a infância, quando lia os livros da biblioteca de seu pai. Quando, ao tomar Hamlet em suas mãos, resolveu se juntar a um grupo de amigos para realizar uma encenação da peça, assumindo para si os papéis de diretor, ator, administrador, compositor e até mesmo instrumentista, devido à sua aptidão natural para imitar os mais variegados sons. Ele, que desde jovem foi um apaixonado pela música; que em 1881 não se dedicava ao ginásio, visto ocupar quase todo o seu tempo com idas a óperas e com as montagens teatrais nas quais auxiliava em tarefas cotidianas como a colocação de cenários e a abertura das cortinas; que em 1885, ingressou na escola de desenho de Kiev e se tornou ajudante do pintor Vasnetsov ; e que em 1890 foi admitido na Escola de Pintura, Escultura e Arquitetura de Moscou; este mesmo homem, que sentia a arte pulsando dentro de si, não deixaria de amá-la por conta de sua vida agitada.

Muito pelo contrário, cada um dos rastros que Sulerjítski deixou em sua juventude e início da fase de maturidade foi fundamental para o enriquecimento de sua personalidade multifacetada e para o futuro trabalho que viria a exercer como diretor e pedagogo do Primeiro Estúdio do TAM.

\footnotetext{
${ }^{9}$ Por influência do escritor Lev Tolstói, Sulerjítski renunciou ao serviço militar em 1895, razão que o levou a ser preso e instalado em um manicômio para o exame de suas capacidades mentais. Neste novo ambiente Sulerjítski se tornou uma espécie de raio de luz para os demais prisioneiros, a quem auxiliava cuidando, escrevendo cartas, dando aulas ou simplesmente aconselhando

${ }^{10}$ Os dukhobors ("lutadores do espírito") eram uma seita que existia desde o século XVII e propagava idéias com as quais Lev Tolstói se identificava, tais como o vegetarianismo, o pacifismo e a negação da propriedade, do Estado, do dinheiro, da igreja e da Biblia como fonte de revelação primordial. Por não possuírem documentos e se recusarem a servir ao exército, os dukhobors já haviam sido banidos duas vezes e em 1894, eram banidos outra vez pelo tsar Nicolau II, uma vez que não lhe haviam prestado o exigido juramento de lealdade.

${ }^{11}$ Foi graças ao auxílio prestado por Serguei Lvóvitch, filho de Lev Tolstói, que Sulerjítki e sua esposa conseguiram uma autorização para voltarem à sua pátria.
} 
Pavel Márkov fala a respeito desta sua faceta de herói aventureiro - no mais belo e profundo sentido desta palavra - , destacando-a como determinante para que o Primeiro Estúdio se tornasse um marco na história do teatro mundial. As experiências de vida pelas quais Leopold Sulerjítski havia passado davam maior peso e profundidade aos seus ensinamentos, pois ele sabia aliar significativamente o seu lado aventureiro ao papel pedagógico desempenhado no Estúdio.

O fato de Leopold Sulerjitski ser esta figura multifacetada foi também de grande relevância para Konstantin Stanislávski. Em suas recordações sobre Sulerjítski, Stanislávski observa o quanto o ofício de diretor é complicado, exigindo uma grande diversidade de papéis por parte daquele que deseja se dedicar a esta tarefa. O que não era um problema para Leopold Sulerjítski, já que:

...a natureza de Suler era complicada e multifacetada, ele era artista,
literato, cantor, ator, administrador e um pouco músico, compreendia
maravilhosamente a escultura e a dança, interessava-se por filosofia,
gostava de psicologia, e etc., etc... Junte-se a isso o extraordinário bom
gosto, o grande temperamento e a imensa capacidade para o trabalho, e
torna-se claro porque Suler tão rapidamente transformou-se em um
verdadeiro diretor e líder cênico. (STANISLÁVSKI,1970) [Tradução
nossa]

Leopold Sulerjítski teve seu primeiro contato com o Teatro de Arte de Moscou na primavera do ano de 1900. Trabalhava então como aguadeiro e foi por meio dos escritores Máximo Górki e Anton Tchekhov - com os quais já travava relações há algum tempo -, que conheceu o TAM, naquela época em tournée pela Criméia,

Sebastópol e Iálta. ${ }^{12}$

A sua primeira aparição num ensaio, porém, ocorreu apenas alguns meses depois, em Moscou. A forma como Leopold Sulerjítski ingressou no TAM gerou certas lendas posteriormente. De acordo com uma delas, o próprio Stanislávski havia lido os escritos literários de Leopold Sulerjítski ${ }^{13}$ e por esta razão mandara chama-lo para o teatro. Mas as recordações deixadas pelo ator Vassili Katchálov se encarregam de esclarecer como foi este primeiro encontro:

\footnotetext{
${ }^{12}$ Foi em Ialta que Leopold Sulerjítski conheceu o TAM.

${ }^{13}$ Sua obra "Na América com os dukhobors", escrita durante sua viagem realizada a pedido de Lev Tolstói. Sobre esta viagem se falará no segundo capítulo da dissertação.
} 
Outono de 1900 em Moscou. O nosso teatro (então ainda não era o TAM, mas o Teatro de Arte Acessível a todos) ensaia "A donzela da neve". (...) E eis que me lembro, numa bela manhã, precisamente uma bela manhã de outono, estando atrasado para o ensaio, eu corria pela Brónnaia. Três homens me ultrapassaram; os três de estatura desigual, diferentes e vestidos de maneira incomum, dois deles mais altos, o terceiro baixinho e forte. Todos os três vem correndo pela entrada principal dos "Románovki". Entro atrás deles e vejo os rostos desconcertados, escuto vozes perplexas: para onde ir agora, a quem perguntar?

O menor, vestido com um blusão de marinheiro, sem gorro, com um corte de cabelo curto e a barba em leque, aparentava ser mais velho que os demais. Ele me fitou rindo, com olhos astutos e apertados e perguntou com um tenor melodioso e elevado e um claro sotaque de Kiev: "Tenha a bondade, diga, por favor, não seria o senhor um artista?" - e explicou que eles todos tinham muita vontade de entrar num ensaio. Eu me lembro de ter murmurado algo, que isso não dependia de mim, que eu estava com pressa, que estava atrasado, aliás, disse que perguntaria ou traria alguém da administração. A seguir verificou-se que ainda não estavam todos reunidos, que eu não me atrasara, e eu então desci outra vez até eles, evidentemente porque estas três figuras haviam despertado meu interesse.

Começou uma conversa. O mais alto dos três, um agradável barítono, falava com leve rouquidão, pigarreando com frequência. Falava muito sobre como eles queriam frequentar os ensaios, que o próprio Nemiróvitch, ainda na primavera em Ialta, os havia convidado a sempre frequentarem o teatro quando estivessem em Moscou. "Este é Górki", apresentou-o o pequeno com uma risada alegre, "o sobrenome dele é assim. Górki, Maximo Górki, o escritor. E um bom escritor. Ainda é jovem, mas já escreve bons contos. E este", ele indicou o segundo, "é um poeta, Skitálets é o sobrenome, tem uma grande voz - voz de baixo, e toca gúsli. E eu sou também uma espécie de escritor, ainda não escrevi nada. Mas vou escrever, sem falta. Meu sobrenome é Sulerjítski, e o mais curto é Suler. Quando eu falo sai parecido com "Shuler", mas isto é porque eu não tenho um dente da frente". (in: POLIAKOVA, 2006, p.106) [Tradução nossa]

Ao conhecer o Teatro de Arte de Moscou, Leopold Sulerjítski ainda não pensava que viria a trabalhar ali futuramente. Isso não o impediu, no entanto, de se apaixonar por este teatro e passar a frequentar diariamente seus ensaios ao lado de Máximo Górki, formando uma espécie de par que, por sua estatura, é comparado por Elena Poliakova a Dom Quixote e Sancho Pança ${ }^{14}$.

Após assistir a um dos ensaios da peça Um inimigo do povo, de $\mathrm{H}$. Ibsen e impressionar-se com a interpretação que Stanislávski dera ao papel de Dr. Stockmann,

\footnotetext{
${ }^{14}$ Gorki era mais alto e magro, enquanto Sulerjítski era mais baixinho e forte.
} 
Sulerjítski escreveu-lhe uma carta em 21 de outubro (2 de novembro) de 1900, antes mesmo que esta peça de linha político-social fosse para os palcos e se tornasse um triunfo na carreira do diretor. ${ }^{15}$

Por meio de seu olhar aguçado a respeito da personagem, Sulerjítski já demonstra nestas linhas uma forte aproximação com o fazer teatral e a busca por uma justificação ética do teatro:

\begin{abstract}
Com sua atuação, em poucas horas, o senhor uniu todas aquelas pessoas que estavam separadas pelo egoísmo frio e, por alguns momentos, deu-lhes a possibilidade de respirar o ar livre das relações boas, amorosas e fraternas das pessoas umas com as outras, sem o que todos sofrem tão brutalmente na vida, mas as pessoas ainda não conseguem estabelecer interações entre si por causa de sua fraqueza e incompreensão. Fazendo isso, o senhor respondeu àquela mesma e principal exigência da verdadeira arte: unir as pessoas entorno do que há de melhor. (SULERJÍTSKI, 1970 p. 395.) [Tradução nossa].
\end{abstract}

A partir desta carta e de seus encontros contínuos, as relações entre ambos só teriam a se fortalecer. Isso porque eles tinham uma forma muito semelhante de olhar para a arte teatral. Para eles, o teatro era não apenas uma arte, um mero ofício, embora muito elevado. Era, antes de tudo, "como uma escola da vida, como um espelho que reflete a vida e ajuda a transformá-la" (POLIAKOVA, 1970, p. 60). [Tradução nossa]

Márkov fala também sobre este amor que Leopold Sulerjítski nutria pelo teatro. Sobre o fato de ele compreender esta arte não como um oficio qualquer, mas como um assunto vital, como um ofício repleto de significado, posto ao lado dos acontecimentos mais marcantes de sua vida:

Ele - uma "criança sábia" conforme a definição de Tolstói incluiu o teatro em sua vida, como antes havia incluído a viagem dos dukhobors, a renúncia ao serviço militar e o longo trabalho como marinheiro, e o amou assim como amava a vida, a água salgada, o mar e sobretudo o homem. (MÁRKOV, 1974, p.355) [Tradução nossa]

No outono de 1906, Leopold Sulerjítski foi aceito oficialmente como assistente do Teatro de Arte de Moscou. A proposta de trabalho surgiu após o regresso do TAM de uma tournée feita em Berlim. Logo que voltou de viagem Stanislávski travou uma longa

\footnotetext{
${ }^{15}$ Esta carta, escrita três dias antes da estreia, surge como uma antecipação daquilo que Stanislávski percebe posteriormente. É exatamente com Um inimigo do povo que Stanislávski compreenderá a força que pode exercer sobre a massa um teatro verdadeiro, uma arte autêntica (STANISLÁVSKI, 1989, p. 333-8).
} 
conversa ${ }^{16}$ com Sulerjítski, nesta época em uma forte encruzilhada entre dois possíveis caminhos a seguir em sua vida: o campo ou o teatro.

Mas a dúvida logo se foi. Embora Leopold Sulerjítski amasse o campo e desejasse comprar uma terra na qual pudesse conviver plenamente com a natureza, ele optou pela arte:

Na primeira oportunidade vou comprar uma terra promissora em Kanev, na província de Kiev, vou largar tudo e partir para a natureza. Mas, por enquanto, preciso viver e trabalhar por este objetivo e por minha família. O melhor de tudo é trabalhar para a arte, no teatro, junto com vocês. Aqui é possível se relacionar com pessoas vivas, e com os sentimentos dizer-lhes aquilo que você não diz com as palavras (SULERJÍTSKI apud STANISLÁVSKI, 1970, p. 549.) [Tradução nossa].

Stanislávski, acolheu-o como assistente e reconheceu posteriormente a importância deste seu feito: "Eu confiei em Súler, aceitei com prazer a proposta de tomálo por meu assistente e não me enganei. Seu papel e sua importância no teatro e na arte se engrandeceram”. (STANISLÁVSKI, 1970, p. 549.) [Tradução nossa].

O trabalho de Leopold Sulerjítski como assistente e diretor do TAM teve início justamente no período em que Stanislávski sentia uma grande necessidade de trazer novas formas e procedimentos para o fazer teatral. Se a situação de desgaste por que passava o teatro em fins do século XIX foi determinante para a criação do Teatro de Arte de Moscou em 1898, eram agora fatores como a desilusão com o naturalismo e a percepção da necessidade de um trabalho totalmente focado na criação do ator que o levavam a repensar seriamente seu trabalho artístico como um todo.

O anseio pela descoberta de novos caminhos levou Konstantin Stanislávski a desejar inovações em suas encenações. Nisso acompanhou-o seu novo assistente, Leopold Sulerjítski, e juntos eles buscaram novas formas para $O$ drama da vida $(1895)^{17}$, A vida

\footnotetext{
16 Esta conversa é relatada por Stanislávski em suas recordações sobre Leopold Sulerjítski. (STANISLÁVSKI, 1970, p. 546-53).

${ }^{17}$ Peça do escritor norueguês Knut Hamsun (1859-1952). Encenada pela primeira vez pelo TAM em 8 de novembro de 1907.
} 
de um homem $(1906)^{18}$, O pássaro azul $(1905)^{19}$ e $\operatorname{Hamlet}^{20}(1601)$, as quais permitiam montagens fora da esfera realista. ${ }^{21}$

Mas se todas estas apresentações tiveram sua importância, foi sobretudo no que diz respeito a Hamlet que Leopold Sulerjítski exerceu papel absolutamente fundamental. Por ser justamente quem melhor sabia a língua inglesa, Sulerjítski assumiu o papel de guia do encenador Gordon Craig, sendo seu intérprete e o principal responsável por toda a comunicação existente entre o encenador inglês, Stanislávski e os atores do TAM.

Esta função de guia e responsável pelos assuntos práticos assumida por Leopold Sulerjítski fica evidente quando observamos parte de sua correspondência trocada com Stanislávski durante o ano de 1911. Em carta de 5 (17) de fevereiro deste ano, por exemplo, Stanislávski escreve de Roma a Leopold Sulerjítski pedindo que de alguma forma reúna-o com Craig, nesta época em Paris:

Pois bem, é impossível que eu vá para Florença. Onde então nos encontraremos com Craig? Em Cannes. Mas lá é temporada e está muito caro. Em Berlim. Isto seria o melhor, e eis porque. Em Drésden existe a escola de danças plásticas e rítmicas de Dalcroize. Eu irei para lá, já que dizem que isso é surpreendente. Isso deve ser interessante também para Craig. Façamos assim. No mesmo dia nós partimos de Cannes ou de outro lugar e Craig de Paris, reunamo-nos em Berlim e vamos para Drésden. Com tempo para trocarmos opiniões sobre aquilo de que precisamos falar, ou seja:

1)Se ele permitiria buscar as disposições dos biombos na própria cena, buscando um estado de espírito geral ao invés de nos apoiarmos com exatidão em suas maquetes.

2)Se, conservando o projeto comum do rei, da corte, de Ofélia e de Laerte, isto é, o caricatural que há neles, Craig permitiria em alguns deles refletir ou dar ao público uma outra forma, isto é, algo mais refinado e, portanto, menos ingênuo. (...) Esclareça com Craig, com este programa em mãos, quando ele acha mais confortável vir: agora ou em Maio? (...) Diga a ele, querido Súler, que tentei escrever-lhe uma carta em alemão. E não pude explicar toda essa complicada embrulhada de minhas propostas, expostas nesta carta. Aí está porque me calei por tanto tempo.

\footnotetext{
${ }^{18}$ Peça do escritor russo Leonid Andreiev (1871-1919). Encenada pelo TAM em 12 de dezembro de 1907.

${ }^{19}$ Peça do escritor belga Maurice Maeterlink (1862-1949). Encenada pelo TAM pela primeira vez em 30 de setembro de 1908.

${ }^{20}$ Famosa peça de William Shakspeare encenada pelo TAM ao lado de Gordon Craig (1872-1966) em 23 de dezembro de 1911.

${ }^{21}$ A utilização de recursos cênicos como linhas de cordas brancas sobre um fundo de veludo negro em $A$ vida de um homem, um fulgor vermelho como alusão ao incêndio em $O$ drama da vida ou a sutileza e os esplêndidos efeitos de luz da dança das horas em $O$ pássaro azul, permitiram que o onírico e o alusivo fossem ao máximo explorados pelo TAM. Estas encenações constituíram importante etapa na busca dos fundamentos criadores do Sistema de Stanislávski.
} 
(STANISLÁVSKI in: SULERJÍTSKI, 1970, p.474) [Tradução nossa]

Pouco depois, em carta de fins de fevereiro de 1911, Leopold Sulerjítski escreve para Stanislávski a seguinte resposta:

Caro Konstantin Sergueevitch,

Estive com Craig e eis o que esclareci:

Ele não quer ir para Drésden, diz que as danças rítmicas não the interessam e pensa que isso tampouco é interessante para o senhor. Por isso também não quer ir para Berlim, que ele odeia. Propõe que o senhor the envie um telegrama de Cannes e ele imediatamente irá para lá.

Pois bem, ele quer se encontrar com o senhor agora em Cannes ou em Capri (considerando o lugar no qual o senhor vai estar) de onde ele deve ser chamado por um telegrama.

Para todas as suas perguntas em relação à apresentação de Hamlet e a interpretação dos papéis ele responde que confia absolutamente no senhor e que o senhor sabe melhor do que ele o que fazer para que fique bom. Portanto, faça como achar melhor.

Parece-lhe melhor chegar em maio.

Eis as respostas às suas perguntas.

Para dizer a verdade, no que diz respeito a chegada dele em maio, eu também manifestei minha própria opinião: penso que é melhor ele chegar mais tarde, quando já terão concluído algo, ainda que qualquer coisa. Caso contrário, ele vai entravar o trabalho e inventar biombos de bronze, de carvalho e assim por diante.

Ele não vai à casa de Górki. Isto é, se ele de passagem desse uma olhadinha seria muito bom. Mas não fica ao lado dele. Isto será muito enfadonho para o senhor. Ele, como quase todos os emigrantes, fala muito, terrivelmente, e o atordoará mortalmente. Perdoe que eu me meta em suas regulamentações, mas sei que isso o aborrecerá e o senhor não descansará e ficará extenuado... (SULERJÍTSKI, 1970, p.480) [Tradução nossa]

Por mais de uma vez Gordon Craig é mencionado por Stanislávski e Sulerjítski em sua correspondência trocada no decorrer de 1911, sendo visíveis tanto aspectos referentes à organização de Hamlet, quanto questões da esfera pessoal do encenador inglês. Em carta de 21 de fevereiro vemos como apesar de não entender o que Craig fazia com o dinheiro que recebia, Leopold Sulerjítski se compadece da situação financeira vivida pelo encenador inglês:

Craig ainda não se zangou. Ele está numa situação terrivelmente desastrosa. Ontem, me pediu emprestados vinte francos, já que não tem um tostão. Onde ele gastou todo esse dinheiro? Se eu tivesse 
recebido tanto, já viveria na datcha e trabalharia no teatro como um mecenas. Entretanto ele não tem dinheiro e rogou que eu telegrafasse ao senhor para que lhe enviassem algo, ainda que qualquer coisa.

(...)

Craig chegou agora e diz que estaria bem mais satisfeito se o pegassem neste prazo, terminassem o trabalho, pagassem e ponto final.

Mas esticaram o trabalho para um prazo sem fim, estão mudando os prazos de sua chegada e ele mesmo não sabe quando será necessário. E, claro, ele estaria bem mais satisfeito de possuir uma condição anual. Agora a sua família já não tem nenhum tostão. Ele mesmo, tampouco. Não há nenhum contrato assinado, algo que ele e o teatro tenham assinado; ele não tem nada contra isso, enquanto o teatro não mudar suas promessas, mas o teatro muda continuamente!

Eis as palavras dele! O diabo desse embrulhão está tomando impulso. Mas evidentemente ele está em grande necessidade e vive apenas com aquilo que recebe de nós. E, provavelmente, na mesma hora absorve isso em sua própria "máscara" e em cada um de seus inventos.

No lugar do teatro eu não abandonaria este artista sem ajuda, mas cuidaria dele como de Górev ${ }^{22}$. Enviaria a ele um dinheiro gradualmente, mas com frequência. Porque por mais que ele não tenha, ele gasta tudo. É preciso mantê-lo o tempo todo, mas não pagar.

Agora ele está sentado a meu lado numa cadeira com um chapéu redondo, coça o queixo, olha para o teto, segura debaixo do braço um livrinho de pergaminho no qual foi desenhado o novo Sistema, o qual ele mostrará apenas ao senhor, e o bastão com castão de osso; franze as sobrancelhas, esfrega o seu queixo e não sabe o que será dele, o que falar, para onde telegrafar e em geral o que fazer. Uma figura infeliz, abatida, que apesar de tudo estimula em mim a comoção e um sorriso.

É preciso mantê-lo. É o que eu sinto agora. O que então fazer se apesar de tudo, no fim das contas ele é uma criança e um artista? É impossível fazer qualquer contrato com ele pois todo o lado do serviço prático sempre estará em desordem ao seu lado. Mas apesar de tudo é preciso mantê-lo de alguma forma. Eis a minha opinião. (SULERJÍTSKI, 1970, p.479) [Tradução nossa]

Mas ainda assim, apesar de toda a atenção dada a Craig durante quase dois anos de trabalho árduo, no momento de colocar o nome dos diretores no cartaz da apresentação, o encenador teimou em colocar apenas o seu próprio nome e o de Stanislávski. Diante disso, Stanilsávski escreveu a Leopold Sulerjítski em 22 de dezembro de 1911:

\footnotetext{
${ }^{22}$ Górev Apolon Fiódorovitch: jovem artista que trabalhou no Teatro de Arte de Moscou de 1903 a 1908. Filho do conhecido ator trágico Fiódor Petróvitch Górev. O jovem e talentoso artista sofria de alcoolismo. O teatro como que o tomou sob sua proteção, amparou-o e protegeu-o.
} 
Querido Lev Antônovitch!

Hoje, o senhor não esteve no teatro, ontem não veio nos ver...

Ou o senhor ficou doente, e nesse caso escreva uma palavrinha sobre o seu estado de saúde, ou o senhor protesta ostensivamente e se irrita, e então começo a ficar chateado por terminar tão tristemente um trabalho começado com alegria. Quando eu fico diante de tais hipóteses, me sinto um tolo e não compreendo nada. Sinto que preciso fazer algo, compreender algo e não sei e nem entendo o que acontece. $\mathrm{O}$ senhor se zangou com Craig pela mudança da luz? Não acredito e não compreendo. Pois Craig criou o cenário e a ideia... (...) Há uma suposição de que o senhor se ofendeu pelo cartaz.

Mais do que eu?

Craig veio com uma choradeira, rejeitou todas as propostas. $\mathrm{O}$ teatro exige que o nome de Craig apareça, já que o escândalo que ele fez se tornou conhecido na cidade. Craig exige no cartaz o meu sobrenome, já que teme a responsabilidade e se mune comigo, como com um bode expiatório. Em meio a todas estas artimanhas, eu devo reconciliar Craig com o senhor ou o senhor com Craig, já que não posso ficar sozinho no cartaz. Eu não penso em nada nesses minutos. Vou atrás de um conselho e o senhor me fala sobre "O pássaro azul". Então eu não entendo nada. (...)

Não se pode viver, viver, e de repente se ofender sem explicar os motivos. Que o senhor está ofendido com Craig eu entendo apesar de também lamentar. Mas.... Craig é um grande artista, é nosso hóspede, e na Europa estão seguindo a sua criação como nós.(...)

Troque a raiva por piedade e não arruíne o bom início com um mau final.....(STANISLÁVSKI in: SULERJÍTSKI, 1970, p.486) [Tradução nossa]

\section{Ao que Leopold Sulerjítski responde prontamente em 23 de dezembro de 1911:}

\section{Caro Konstantin Serguéevitch!}

Craig é um grande artista e como tal se conserva e se conservará para mim eternamente. Que ele é nosso hóspede também sei e aparentemente no decorrer de dois anos de trabalho com ele provei que consigo aguentar tanto a rudeza e a irritabilidade, quanto a confusão deste homem e, apesar disso, amá-lo sinceramente.

Que a Europa o acompanhe, para mim decididamente dá na mesma, e minha atitude não mudaria com relação a ele ou com qualquer outra pessoa por conta disso.

Iluminar ele pode, como queira, este é o seu direito e eu não tenho nada contra isso, ajudei-o e amanhã trabalharei na iluminação do "quarto", pois no espetáculo, assim como em toda a peça, os biombos não estão sozinhos, há também o meu 
trabalho e o seu, bem como o trabalho do teatro, e uma vez que é preciso reformar algo, então vou reformar, já que é o senhor, o diretor principal da peça, quem quer isso.

E além do mais, por enquanto "Hamlet" não está terminado, estou pronto para executar as tarefas de Craig, inclusive no caso de elas irem de encontro às minhas opiniões, uma vez que apenas o senhor considera que Craig está correto.

No campo do trabalho artístico eu não posso estar ofendido, isso seria engraçado e tolo. O senhor sabe disso muito bem, e sabe o porquê: porque eu já acredito pouco demais em mim mesmo e em minhas forças, tanto mais quando trabalho com o senhor.

Não é inteiramente assim com Craig.

Quando ele fala sobre as linhas, o desenho, a composição e inclusive a iluminação, eu sinto, que isto é Craig, mas quando a questão se refere à direção, então aqui eu não fico convencido de ele estar incontestavelmente correto: ele se interessa muito pouco pelo ator.

Deste ponto de vista "a ratoeira" ${ }^{23}$ é iluminada com pouco êxito, e se ela teve sucesso no ensaio geral, então não foi graças à iluminação, mas apesar desta iluminação. Todos se queixaram de não verem Hamlet, e o público da primeira apresentação não perdoará o teatro por isso.

Mas também essa mudança não me ofende e nem pode ofender. Eu posso lamentar que esta luz prejudique o espetáculo e Katchálov $^{24}$, mas de modo algum me ofender, visto que mais uma vez acredito pouco em mim mesmo e facilmente consinto em pensar que estou errado, embora me dê pena que o senhor tão rapidamente tenha cedido à opinião de todos, já que o senhor discutiu com Craig cerca de dez minutos sobre isso, dizendo que em tal escuridão é impossível representar, que para os biombos é bom, enquanto para os atores e para o espetáculo é ruim.

Mas repito, também aqui não há nenhuma ofensa.

Craig não quis que eu estivesse no cartaz, depois de dois anos de trabalho pesado, depois de muitos, como dizer, sacrifícios feitos a ele, reconhecendo que sem mim é pouco provável que ele tivesse sucesso na condução de seu trabalho em nosso teatro pelo menos até o final, e isto é inesperado para mim.

E só.

Mas não é ofensivo.

O Craig-artista ficou para mim, o Craig-amigo se foi para sempre, completamente.

Conheci bem este tipo de inglês durante o tempo da minha atividade na Inglaterra e na América.

Não pode haver nada em comum entre eu e ele e, portanto, não haverá. Aqui não existe nenhuma ofensa, mas eu nunca vou realizar nenhum trabalho com ele: apenas não é interessante trabalhar com um homem assim, e isso é tudo.

E o trabalho dele, o que quer que seja, eu verei com prazer, como sempre vi.

23 "A ratoeira" - cena do terceiro ato de "Hamlet", uma das mais interessantes no espetáculo do TAM.

Craig construiu esta cena com bruscos contrastes de sombra e de luz. (N.T.)

${ }^{24}$ Vassili Ivanovitch Katchálov: ator do TAM. Fez o papel de Hamlet nesta encenação (N.T) 
Onde unicamente tive todo este tempo uma sensação de ofensa imediata, bastante pungente, foi quando o senhor pôs-se a perguntar o que se há de fazer comigo e com Craig que diz que não quer que eu esteja nos cartazes.

A ofensa esteve no fato de que por dias não eu (eu penso o contrário), mas o senhor mesmo me disse que era preciso me colocar no cartaz, já que em sua opinião, para mim isso era importante, em vista de eu estar trabalhando ao seu lado. Mas custou a Craig - não ao Craig-artista, mas ao Craig aventureiro, ao descarado negociante que se encontra dentro dele e com o qual ele surge nesta história - querer isso, e o senhor considerando que ele foi injusto comigo, e pensando que para mim isso era importante, ficou pronto imediatamente, no mesmo instante, para me sacrificar a ele, e ainda por cima me pergunta em pessoa sobre isso.

Involuntariamente me lembrei de como sempre que estive no meu direito mas foi preciso me defender, o senhor, minimamente pressionado, e inclusive a partir de uma possibilidade de pressão, imediatamente esteve pronto para sacrificar a mim e a meus interesses, não apenas os imaginários, como neste caso, mas também os verdadeiros.

E sempre sacrificava.

E entretanto eu vejo que com seus outros amigos o senhor pode fazer o mesmo, e fazer vigorosamente, para que os interesses deles não sofram injustamente.

E quando tudo isso é lembrado junto, como eu me lembrei da última vez, então se torna muito ofensivo e surge a questão : estariam corretas as nossas boas relações?

Muito em breve isso se esquecerá, mas a marca de cada caso desses permanece involuntariamente na alma e leva a uma unhada de leve em nossa relação.

E só.

Ofensa houve, eu a senti algumas horas, mas depois ela se foi e ponto final.

O senhor diz que é preciso terminar bem aquilo que começou bem. É preciso dizer isso a Craig e ao senhor, não a mim.

Para finalizar:

não estou ofendido com Craig pela conduta dele, mas as pessoas capazes disso não me interessam: não são companhia para mim, eu simplesmente evito encontros com pessoas assim e de nenhuma forma me reúno com elas nem para ensinar nem para reeducar; há muitas destas, para mim enfadonhas e desagradáveis e eu apenas as evito.

E para o senhor, eu juro: não é nem a primeira e nem será a última vez que me ofendem.

Vai ser sempre assim.

Não havia nada em mim que impedisse de tratar comigo, tanto mais que o senhor nem observa tais casos. Não é possível fazer nada, então.

Mas se acumular unhadas demais deste tipo, tantas, que elas salguem algo intacto, então provavelmente nossas boas relações arrefecerão. 
Mas a vida é curta e casos assim são pouco frequentes, de modo que existem lugares de sobra para as unhadas e isso significa que tudo caminha como antes.

Abraço-o, Seu Sulerjítski (SULERJİTSJKI, 1970 p.487-9) [Tradução nossa]

Apesar deste episódio, a situação não se estendeu e nem terminou mal como temia Stanislávski. Muito pelo contrário, a peça estreou em 1912 e, apesar de Stanislávski e Craig não terem ficado muito satisfeitos com seu resultado, obteve grande sucesso ${ }^{25}$.

Das quatro peças encenadas pelo TAM na época em que Sulerjítski foi assistente de direção, Hamlet foi sem dúvida - ao lado de $O$ pássaro azul - aquela em que o diretor mais se destacou, desempenhando papel fundamental. Além de todo o auxílio prestado a Craig, a significação de Leopold Sulerjítski se estendeu também no que diz respeito à própria encenação, uma vez que ele interferia com suas ideias e fez de tudo para fortalecer a fé de Stanislávski numa interpretação que realçasse o tema moral da tragédia de Shakespeare, despertando o lado humano nesta encenação.

Despertar o lado humano através da arte foi um dos grandes objetivos de vida de Leopold Sulerjítski. Este seu desejo pulsava dentro dele desde o ano 1905, quando após ter assistido à tragédia da derrota da revolução russa, Sulerjítski decidiu tomar para si a tarefa de revigorar o mundo moralmente de alguma maneira. Por isso, a partir do momento em que se tornou assistente de direção do Teatro de Arte de Moscou em 1906 e até o fim da vida, vemos rastros deixados por ele nesta direção.

Em 29 de agosto de 1915, época em que ele já trabalhava no Estúdio, lemos a seguinte entrevista dada ao jornal Utro Rossíi:

Nós perguntamos como a guerra conseguiu se manifestar no Estúdio na apreciação das obras de arte e nas tarefas habituais da arte.

A guerra - foi a resposta - com uma particular agudeza apresenta as tarefas habituais da arte. Coloca-se cada vez com maior insistência a tarefa de juntar todos os esforços para a realização do objetivo fundamental da arte: despertar o humano no homem. Este é o princípio que orienta todos os trabalhos do Estúdio. A principal atenção dos diretores do Estúdio está voltada para a expressão de uma ideia. Neste ano e no ano passado, durante a escolha das peças, durante os ensaios e apresentações nós nos esforçamos por encontrar e propor tudo aquilo que une as

\footnotetext{
${ }^{25}$ Para detalhes desta encenação realizada pelo Teatro de Arte de Moscou ver TAKEDA, C. L. O cotidiano de uma lenda. Cartas do Teatro de Arte de Moscou, São Paulo, Perspectiva, Fapesp, 2003, p.373-403
} 
pessoas, tudo o que fala sobre aquele humanismo que testemunha a origem divina no homem.

Destas buscas pelo humanismo, pela cordialidade, surge a lógica do repertório da temporada. Assim, a primeira encenação é a renovação de "O grilo na lareira" e desenha um início favorável, encarnado por um grande homem com um "grande coração": Dickens.

A segunda e nova encenação é "O dilúvio" constitui uma antítese da primeira. É uma sátira da vitória sobre o homem que começou a oposição.

Em relação ao exposto, se houver de nossa parte um trabalho intenso sobre a forma, então como objetivo sempre restará manifestar por meio da forma o conteúdo, a ideia geral... [Tradução nossa]

Como então, não o considerar diretor de teatro?

Diante do fato de ele ser esta figura multifacetada, de amar o teatro, de estar presente num período crucial para o desenvolvimento das novas ideias de Stanislávski, de participar de importantes montagens do TAM e sobretudo, diante do fato de ele colocar a questão do humano em primeiro plano, é impossível não enxergarmos a sua significação dentro deste campo.

A verdadeira arte pressupõe a humanidade dentro de si e foi exatamente isso que Leopold Sulerjítski rapidamente compreendeu. Foi exatamente esta semente, a semente da humanidade e do amor pelos homens, que ele plantou no início de seu trabalho no TAM. E que, como veremos a seguir, floresceu com exuberância no decorrer de sua atividade artística a partir de então.

\subsection{O Estúdio como ponte para o Sistema}

O fenômeno que foi o aparecimento dos Estúdios Teatrais é descrito por Pavel Márkov como algo natural e que necessariamente deveria fazer parte da história do teatro russo. Era impossível que os teatros existentes continuassem a dar conta das novas ideias que surgiam. Portanto estas novas células que foram os Estúdios, apareciam na qualidade de novos centros de teatro, locais onde era possível realizar experimentos e jogos com os atores sem interferir no andamento da vida teatral do país.

Konstantin Stanislávski, que há algum tempo vinha buscando novas formas de trabalhar com os sentimentos e de educar os atores para que pudessem controlar as emoções e saber precisamente quando utilizá-las, teve uma importante participação neste 
fenômeno natural da história do teatro russo. Aproveitando o seu desejo de colocar em prática o seu Sistema que vinha sendo elaborado nesta época, decidiu abrir um Estúdio Teatral. E para tal empresa, contou com a participação de Leopold Sulerjítski, que há muito o apoiava na criação e divulgação de seu Sistema.

A esposa de Leopold Sulerjítski, Olga Sulerjítskaia, conta em suas recordações sobre como o marido se encontrava com Stanislávski diariamente e como ambos tinham conversas intermináveis sobre o Sistema. Essa proximidade e compreensão mútua, quando praticamente mais nenhum dos conhecidos de Stanislávski dava ainda tamanho valor ao Sistema, fez com que em 1910 Sulerjítski fosse o encarregado de organizar todo o material escrito por Stanislávski sobre este assunto até então.

Isso ocorreu quando Stanislávski adoeceu de tifo em 1910 e Leopold Sulerjítski, indo contra as ordens do TAM, largou todas as suas atividades em Moscou para cuidar do enfermo durante dois meses. Ele não apenas levou os medicamentos necessários para o tratamento de Stanislávski, como também a argila para que o doente pudesse moldar os personagens da encenação de Hamlet, nesta época ainda em processo de criação. Quando Sulerjítski voltou para Moscou, levou consigo uma bagagem pequena, composta em sua maior parte por manuscritos tanto da época anterior à doença, quanto do período da tifo. Stanislávski pediu a Sulerjítski que o quanto antes colocasse suas anotações em ordem, reimprimisse e em seguida lhe enviasse tudo outra vez para que sua esposa Maria Petrovna fizesse a devida conferência no material.

Ademais, como uma forma de experimentarem o Sistema, Sulerjítski já aplicava as ideias de Stanislávski desde 1911 na escola dramática criada por Aleksander Ivánovich Adáchev $^{26}$. Nesta escola, reunindo grande afinco e paciência Sulerjítski se dedicou à tarefa de passar aos alunos tudo o que vinha aprendendo com Stanislávski há algum tempo.

Em livro dedicado às suas experiências artísticas ${ }^{27}$, a atriz Serafima Bírman, aluna de Sulerjítski na escola de Adáchev e futura atriz do Estúdio, fala sobre como inicialmente a aparição de Leopold Sulerjítski espantou os alunos. Como assim, este homem com barbas e bigodes, com estas roupas e que não é artista de verdade ia dar aulas na escola particular de Adáchev? Era o que se passava na cabeça dos alunos. Mas logo todos aprenderam a respeitar e se entusiasmar com as aulas do novo professor. E

\footnotetext{
${ }^{26}$ A. I. Adáchev (1871-1934): Ator do TAM de 1898 a 1913. Sua escola de teatro esteve em funcionamento de 1906 a 1913.

${ }^{27}$ Serafima Birman - Sudboi darovanie vstretchi (1971)
} 
com o tempo a própria atriz percebeu que "O teatro do futuro, o Teatro com letra maiúscula se tornou o objetivo de Sulerjítski. Ele se entregou por inteiro ao novo trabalho, completamente.” (BÍRMAN, 1971, p.42) [Tradução nossa]

Em 1912 Stanislávski e Sulerjítski juntaram um grupo de jovens artistas - o que incluía alguns dos atores da escola de Adáchev, tais como Serafima Bírman e Evguéni Vakhtângov - e a partir desta junção inauguraram o Primeiro Estúdio do TAM num pequeno espaço da Rua Tverskáia. Este novo ambiente, sem palco e semelhante a um auditório sem cátedra, permitiria daí por diante a busca pelos novos princípios de encenação.

No dia da inauguração Stanislávski discursou a respeito de seus planos e expectativas com relação ao Estúdio. Em suas palavras evidenciou-se a preocupação em aperfeiçoar o Sistema e ao mesmo tempo em utilizar métodos inovadores que buscassem aprimorar a criatividade do ator. De acordo com anotações deixadas por Leopold Sulerjítski, Konstantin Stanislávski teria dito neste dia que:

O Estúdio vive ao lado do Teatro de Arte para ajudá-lo. Ele se ocupa das questões do trabalho criador do ator (o Sistema), formando o artista pedagogicamente, proporcionandolhe a prática com a ajuda de exercícios diários e, possivelmente, no futuro, os espetáculos paralelos.

.... Realiza novas experiências de atividade criadora coletiva de autores, atores e diretores sobre a criação das peças (método de Górki ${ }^{28}$ ). Experiências com os efeitos de luz e de decoração, e com as possibilidades cênicas. Experiências com pantomima para grandes apresentações de espetáculos. Experiências com relação à parte econômica. A busca pelas formas de gerir corretamente a economia teatral. ${ }^{29}$ (STANISLÁVSKI apud POLIAKOVA, 2006, p. 181.) [Tradução nossa].

As anotações de Sulerjítski acerca do discurso de Stanislávski já comprovam a grandeza do projeto idealizado por ambos. Da criatividade do ator ao trabalho de gestão; da formação pedagógica à prática de exercícios; da atividade dramatúrgica ao trabalho de direção. Tudo era indispensável à sua arte e deveria ser contemplado pelos novos integrantes do Estúdio sem que houvesse menosprezo a qualquer das funções

\footnotetext{
${ }^{28}$ Método através do qual o dramaturgo passaria a escrever as peças a partir das vivências e criações dos atores.

${ }^{29}$ De acordo com Poliakova (2006, p. 182), Sulerjítski anota ainda que a menção à tarefa de gestão das economias deixou espantados os artistas presentes, os quais não esperavam ter também a partir daí a tarefa de um contador
} 
relacionadas ao fazer teatral. Era necessário nutrir os artistas do futuro com todas as possibilidades pertencentes ao seu presente. Prepará-los para a arte e para a vida.

De fato, o caráter experimental foi o que guiou o Estúdio inicialmente. Stanislávski tinha consciência de que nenhuma constatação pode partir do vazio. Para que o Sistema ganhasse a força que tem hoje, era preciso que não ficasse apenas na teoria, mas que fosse também para a prática. Somente a efetiva aplicação de seus conceitos, a tentativa, as dificuldades, a nova tentativa e enfim a tão esperada conclusão a partir do real trariam uma base mais sólida para as constatações feitas por Stanislávski.

Os cadernos de Stanislávski deixam bem claro este caráter constante de busca e experimentação ${ }^{30}$. Em anotação feita entre 1908 e 1913 Stanislávski fala do sentimento afetivo. Começa por refletir teoricamente acerca da questão proposta ${ }^{31}$ e em seguida parte para o relato da experiência vivida e conta sobre o dia em que durante uma aula foi solicitado como tarefa que os alunos sentissem temor ${ }^{32}$. Neste caso o experimento deu-se a partir de certos estímulos, excluindo-se na medida do possível a tensão muscular ${ }^{33}$, que será um dos elementos bastante abordados pelo Sistema.

A experiência parecia bem-sucedida e de acordo com Stanislávski todas as vivências haviam sido atingidas sinceramente. Até que o professor resolveu pintar os afetos com a cor do medo e todos os alunos, por hábito, puseram-se tensos: "O hábito cênico ocupou o primeiro plano e por isso a imagem (a representação) do medo se tornou mais perceptível do que a vivência afetiva.” (STANISLÁVSKI, 2015, p. 209). Enquanto o professor utilizava o ocorrido para falar a respeito do medo, um aluno, ainda sentado, chamou a atenção do grupo. De acordo com Stanislávski:

... ele quis levantar e murmurou alguma coisa, mas não conseguiu se levantar. (...) percebemos que ele estava pálido e realmente assustado, e não conseguiu logo entender o que estava

\footnotetext{
${ }^{30}$ Vários destes cadernos de anotação de Stanislávski encontram-se atualmente traduzidos e incluídos na recente publicação Stanislávski, vida obra e Sistema (2015) de Elena Vássina e Aimar Labaki.

${ }^{31}$ Lê-se aqui a seguinte anotação teórica "Se graças à excitação criadora, você sente inconscientemente algum sentimento que já tenha experimentado... Quando e como isso aconteceu - eu não me lembro, mas as lembranças dessa sensação permanecem. Assim como, às vezes, você sente que um mesmo momento é repetido na sua vida. Em algum momento e em algum lugar a mesma coisa aconteceu, mas eu não me lembro onde. É isso o afeto dos sentimentos (...) O ator precisa do afeto do sentimento: consciente (ainda melhor) ou inconsciente (...) (VÁSSINA, E.; LABAKI, A.).

${ }^{32}$ Esta anotação não tem sua data conservada e não é possível saber ao certo quem era o professor, quem eram os alunos ou em qual escola se dava a aplicação deste experimento.

${ }^{33}$ De acordo com Stanislávski é imprescindível que o ator aprenda a relaxar os músculos. Para ele, "Enquanto existe tensão física não se pode falar em sensações corretas e sutis, nem em uma vida espiritual normal da personagem. Por isso, antes de iniciar a criação, é necessário colocar em ordem os músculos para que não paralisem a liberdade de ação.” (VÁSSINA, E.; LABAKI, A., 2015, p. 303).
} 
acontecendo ao seu redor e o que lhe perguntavam. Verificou-se que vivenciando o medo afetivamente e tentando matar o hábito cênico, ou seja, relaxar os músculos, o aluno (Sulerjítski), sem querer, lembrou-se não pelo pensamento, mas pelo sentimento, de um momento parecido em sua vida. Ele estava na cela de uma prisão, ouviu o barulho de chaves na porta e entraram algumas pessoas desconhecidas. Ele ficou tão assustado que não conseguiu se levantar. Agora ele não se lembra de quem eram essas pessoas e porque vieram, não se lembra de seus rostos, mas só se lembra da sensação: a fraqueza do corpo por causa do medo. Lembrando, na vivência afetiva, do medo, ele involuntariamente se lembrou do momento análogo e mais marcante da sua vida. (STANISLÁVSKI in: VÁSSINA, E, LABAKI,A., 2015, p.209) [grifo nosso].

De discípulo atento a mestre do Primeiro Estúdio, seria agora Leopold Sulerjítski a aplicar na prática todos os ensinamentos que tão bem vinha conservando desde o início de seu trabalho ao lado de Konstantin Stanislávski.

A prova de que Sulerjítski estava sempre refletindo e guardando consigo as lições de Stanislávski são os diários o próprio Sulerjítski manteve entre 1912 e 1916. Estas anotações de diário, atualmente conservadas em cópias datilografadas nos arquivos da Biblioteca estatal de Arte e Literatura de Moscou (RGALI) ${ }^{34}$ e em parte publicadas na revista Vestnik teatra de 15 de fevereiro de $1919^{31}$, revista esta encontrada na Biblioteca Lenin, são em grande medida reveladoras das inter-relações existentes entre o pensamento artístico de Leopold Sulerjítski e Konstantin Stanislávski

Desde a primeira anotação dos diários é perceptível a conexão existente entre os pensamentos de ambos quando Leopold Sulerjítski diz "Vulgaridade e grosseria: eis aí as duas coisas mais cansativas para mim. No entanto, é se obrigado a dar de encontro com elas e aguentá-las diariamente. Ás vezes, eu aguento, às vezes, isso irrita tanto que eu não consigo mais suportar. (...)” (SULERJÍTSKI, 1970, p. 341) [Tradução nossa]. Com estas palavras Sulerjítski está apontando nitidamente para um dos principais alvos contra os quais Konstantin Stanislávski iria lutar por toda a vida no teatro: a vulgaridade em cena.

Em Minha vida na arte ${ }^{35}$ não são poucas as passagens em que Stanislávski se revela estar farto dos clichês cênicos e de tudo aquilo que em geral ele considera vulgar em uma realização teatral. Em meio a suas incessantes buscas por uma arte menos desgastada e

\footnotetext{
${ }^{34}$ As anotações mantidas no arquivo estão em sua maior parte publicadas no livro de Elena Poliakova. ${ }^{31} \mathrm{~A}$ revista publica nesta data as anotações de diário referentes à histeria feitas em 9 de dezembro de 1913.

${ }^{35}$ Livro já traduzido para o português por Paulo Bezerra.
} 
que lhe preenchesse o vazio que vinha sentindo em sua alma de ator no início do século XX, Stanislávski diz que:

Para transmitir cenicamente as vivências genéricas ou sublimes do poeta existe entre os atores todo um acervo especial de clichês desgastados como o levantar dos braços com as palmas da mão e os dedos abertos, com o gestual teatralizado, o marchar teatralizado em vez do andar, etc. É exatamente assim! Em nós sedimentaram-se dois tipos de gesto e movimento: uns comuns, naturais, cheios de vida, outros incomuns, contranaturais, sem vida, empregados para transmitir no teatro todo o sublime e abstrato. Este último tipo de gesto foi assimilado há muito tempo dos cantores italianos ou de maus quadras, ilustrações e cartões postais. Através dessas formas vulgares será possível transmitir o supraconsciente, o sublime e nobre que há na vida do espírito humano, aquilo que torna Vrubel Maeterlink ou Ibsen belos e profundos? [grifos do autor] (STANISLÁVSKI, 1989, p. 389).

Em suas anotações escritas entre novembro e dezembro de 1913, Stanislávski continua a tratar do mesmo tema. Ele entende o clichê como algo normal, mas que o ator deve arrancar como se arrancam as ervas daninhas que sufocam uma flor. Pois a presença do clichê em cena não apenas sufoca o ator, como também cumpre o papel de um ruidoso tambor, o qual não permite que o ator ouça a sua vivência interior, ou seja, o violino que tenta incessantemente tocar dentro de si e se fazer ouvido.

Curiosamente nesta mesma época, precisamente em 9 de dezembro de 1913 Leopold Sulerjítski se encontra às voltas com a questão do clichê cênico e escreve a este respeito em seu diário:

Me parece que existem dois tipos de esforços e clichês: o muscular e o nervoso.

O muscular é quando uma pessoa, sem sentir nada, tenta lembrar de cabeça como forçar a contração dos músculos que participam das manifestações deste ou de outro sentimento, tentando, desta forma, passar um sentimento. Alguns atores fazem isso com muita habilidade, muita semelhança e até mesmo com um interior absolutamente vazio; mas apesar de tudo, nós, isto é, nosso teatro, inclusive os alunos, com bastante facilidade o reconhecemos e descobrimos.

Já o outro clichê é o nervoso, quando o ator encontra o sentimento vivo, através da análise correta da peça, do núcleo, da ação transversal, através das tarefas, etc., isto é, encontrando o caminho tanto em si quanto nos sentimentos vivos e depois, gradualmente se esquecendo de para que existem estes sentimentos, o ator começa a viver apenas com os sentimentos, irritando os próprios nervos sensoriais através dos quais estes 
sentimentos passaram ao serem criados. Ele até é sincero nos próprios sentimentos, mas está sem objetivo e, portanto, é desnecessário em cena.

O primeiro clichê é possível sem qualquer trabalho sobre o papel, enquanto que o segundo se formará nos espetáculos. O primeiro me parece semelhante ao homem que arranca com as mãos uma flor da terra, para que ela cresça, arruma os botões com os dedos, etc., completamente esquecido das raízes. O segundo planta uma semente, cuida das raízes, rega e afofa a terra enquanto a flor não cresce. E quando ela cresce, então abandona gradualmente as raízes e dá toda a atenção para a flor; e para que ela fique mais bonita, começa a pintá-la com tintas óleo; por causa disso as raízes secam ainda mais e as flores, por sua vez, também devido a isso empalidecem; então pintam-na ainda mais, toda a planta murcha completamente e o que resta é uma boneca morta, repugnante e borrada.

Mas onde está aquele que tratará sempre apenas das raízes e alcançará a exuberante florescência de toda a planta? Há poucos destes. Este é o destino dos grandes talentos. Ou (em parte) daquelas pessoas que, embora não extremamente talentosas, têm uma visão de mundo ampla e abrangente, para as quais nunca os próprios sentimentos, a força que possuem, a sua exibição para a massa - e, portanto, o seu engrandecimento diante dela - estará em primeiro plano e nem ofuscará a razão pela qual the é agradável e alegre vivenciar estes sentimentos em cena. (SULERJÍTSKI, 1970, p. 347). [Tradução nossa].

Assim como no caso de Stanislávski, não era esta a primeira vez que Leopold Sulerjítski tratava dos clichês. Em uma apresentação oral realizada em 25 de outubro de 1909 no Museu Politécnico, Sulerjítski diz que:

Todo ator sempre tem no estoque alguns "clichês" preferidos (uns têm dois, outros três ou seis). E quando o ator está vazio, quando o papel não se dá, mas é preciso tanto falar quanto atuar de uma forma ou de outra, imediatamente aparece um "clichê" ou uma combinação deles para ajudar. Esta maneira convencional, este clichê que em alguns atores é extraordinariamente agradável, encantador e até nobre, na maioria dos casos é tomado por individualidade na imprensa e no público, visto que cada ator é outro, ainda que sua construção interior seja sempre a mesma. (SULERJÍTSKI, 1970, p. 319) [Tradução nossa].

Mas apesar de o clichê estar presente em outros momentos de sua vida, esta questão se torna muito mais potente em suas anotações de 1913 por vir acompanhada de 
um acontecimento marcante ocorrido no Primeiro Estúdio, isto é, precisamente a apresentação da peça A festa da paz (1890), de Gerhart Hauptmann. ${ }^{36}$

Esta peça foi dirigida por Vakhtângov sob a supervisão de Leopold Sulerjítski e apresentada em 15 de novembro do mesmo ano. Mas diferentemente de outras encenações do Estúdio sobre as quais falaremos mais adiante, esta peça não deu bons frutos, ao menos para Stanislávski e o próprio Sulerjítski que ficaram descontentes com seu resultado. Sobretudo porque durante a encenação uma das senhoras da plateia entrara em histeria. Elena Poliakova (2006, p. 201) assim descreve o ocorrido:

\begin{abstract}
O espetáculo está sendo interpretado para os espectadores. Na sala de 120 lugares respira-se em uníssono com a família Sholtz. Gritos histéricos - evidentemente que femininos -, acompanham a ação cada vez com maior frequência. As damas, modestamente vestidas como senhoras-estudantes ${ }^{37}$ ou empregadas (há cada vez mais destas - telefonistas, datilógrafas, estenógrafas, secretárias e desenhistas) choram na sala até que o choro se transforma em gritos, em asfixia. Uma mulher sai em meio à ação, ou são obrigados a levá-la pela mão. A dar-lhe amoníaco para cheirar. A ajudá-la até que chegue ao banheiro feminino, onde pode se sentar, se empoar e partir daí num cocheiro em direção ao próprio apartamento com um pinheiro e uma ranhura no assoalho. [Tradução nossa].
\end{abstract}

A partir deste acontecimento, a histeria passou a ser repudiada ainda mais por Sulerjítski, não apenas em seu diário, como também em conversas com os alunos do Estúdio.

Do primeiro caso é prova irrefutável desta condenação a longa anotação feita em dezembro de 1913, a qual contém frases como "Alguém que se agita em histeria sempre dá pena, tal como uma pessoa num ataque epilético" (SULERJÍTSKI, 1970, p. 342) (tradução nossa), “A histeria é contagiosa” (Ibidem, p. 344) (tradução nossa), ou "A histeria no teatro, em obras dramáticas é um indicador tão ruim para o ator quanto uma gargalhada animalesca do público em obras cômicas" (tradução nossa), entre outras ${ }^{38}$.

Do segundo dá provas um breve relato feito pela atriz do Estúdio Sofia Guiatsintova, que neste caso fala sobre a repercussão da peça de Hauptmann. Após contar como Konstantin Stanislávski condenou severamente este espetáculo e como os atores

\footnotetext{
${ }^{36}$ Gerhart Haupmann (1862-1946), dramaturgo naturalista.

${ }^{37}$ A palavra aqui é Kursistki, isto é, estudante de curso superior na Rússia antes da Revolução de Outubro.

${ }^{38}$ Estas anotações de diário encontram-se traduzidas integralmente do original em anexo ao fim deste trabalho.
} 
choraram baixinho diante de seu fracasso perante o diretor, a atriz do Estúdio fala a respeito da recepção geral da peça em contraposição à reação de Sulerjítski:

O espetáculo foi bem recebido: as acusações de histerismo e de "conversa caseira cotidiana", etc., feitas por alguns críticos afundaram diante de pareceres entusiastas de outros críticos, que afirmavam que na cena do Estúdio acontecia um milagre psicológico: a autenticidade dos sentimentos, a descoberta das vivências, o desnudamento dos corações. Os espectadores seguiam os acontecimentos com tensão e frequentemente rompiam em prantos. Nós gostávamos disso, mas Sulerjítski sofria por uma compreensão tão selvagem do sucesso e ralhava conosco.

- Entendam - esganiçava-se ele - uma vez que na sala há histeria, quer dizer que vocês interpretam abominavelmente! Vocês precisam conquistar a fantasia, a alma, mas vocês atraem os nervos. Isso não é da arte!

Nós acreditávamos em Leopold Antonovitch, mas, como esconder? Ainda mais com os soluços e os aplausos. E é claro que nós mesmos já nos tínhamos em alta conta num dia em que depois do espetáculo vimos Górki. Aproximando-se de nós por um canto rangente da escada, ele chorava em um lenço enorme. Atrás dele, também chorando, vinha Maria Fedorovna Andreevna. Eles nos elogiaram, surpresos em ver como com tal juventude nós mostramos uma arte completamente 'adulta'. A admiração deles fortaleceu a reputação do espetáculo, ainda que o correto, é claro, fosse Suler; mais tarde nós compreendemos isso. (GUIATSINTOVA, S. 2011, p. 364) [Tradução nossa].

Sulerjítski estava ciente desta apreciação do público. Ele sabia, assim como Stanislávski, que os espectadores inevitavelmente buscavam o entretenimento no teatro. Mas não desejava que a arte teatral servisse apenas como um meio de entreter, e por isso condenava ferrenhamente quaisquer obstáculos que afastassem o teatro de seu significado mais profundo. Para ele:

\footnotetext{
A histeria é contagiosa.

Eis que isso ocorre agora.

E eis porque eu não gostei deste ataque de nervos que nós tivemos no Estúdio. Este é um caminho perigoso. Um espetáculo assim pode ter um sucesso estrondoso, já que o público gosta, adora isso que chamamos de "forte impacto", assim como gosta da tourada, da luta, do teatro de horrores, dos terríveis exercícios com fogo, dos saltos, perigosos para a vida: tudo aquilo que "abala" e, portanto, entretém, sem aprofundar. Mas então o teatro deixa seu pedestal e põe-se no nível de tudo aquilo que é entretenimento... (SULERJÍTSKI, 1970, p. 344-5) [Tradução nossa].
} 
Para Márkov, com sua condenação à histeria Sulerjítski resistia a todo tipo de clichês que faziam com que o ator abandonasse a sensível interpretação que havia no pequeno teatro do Estúdio, cara a cara com o espectador. Pois seria impossível a um só tempo buscar a pureza da atividade criadora e entrar em histeria. Assim:

\begin{abstract}
Sulerjítski formulou corretamente os perigos que estavam encerrados no profundo psicologismo e as contradições, das quais desejava ardentemente fugir. Cada apresentação do ator em cena deve ser uma nova atividade criadora; a interpretação que se extinguia - como ele observou com frequência - convertia-se em perigosos clichês. (MÁRKOV, 1974, p. 360) [Tradução nossa].
\end{abstract}

O maior perigo estava, assim, justamente no fato de tal contagio levar o público a participar do espetáculo também da mesma forma que o ator, isto é, entrando em histeria. O que não seria difícil de acontecer, já que a histeria é por Sulerjítski apontada como altamente contagiosa:

\begin{abstract}
A histeria é terrivelmente contagiosa e a cada ano que passa nessa nossa vida insensata torna-se mais contagiosa, tanto psicologicamente (dos desejos mesquinhos e fúteis de chamar a atenção para si mesmo), quanto fisicamente (das inverossímeis e insanas condições de vida, da falta de trabalho físico e de tudo aquilo, que tão irremediavelmente desmancha nossos nervos e abre terreno para todo tipo de doenças nervosas). [Tradução nossa]
\end{abstract}

Apontada pela psicanálise como uma anomalia do Sistema nervoso, fundamentada na distribuição diferente das excitações, e cuja sintomatologia é composta por fatores como ataques convulsivos, paralisia e distúrbios da atividade sensorial, podendo haver ocasionalmente instabilidade da vontade e alterações de humor, (FREUD,1987, p.43-57), a histeria estava absolutamente em desacordo com os princípios artísticos responsáveis por mover Leopold Sulerjítski em suas atividades no Primeiro Estúdio.

Ao gritarem, se debaterem e deixarem que seus corpos os comandassem ao invés de eles mesmos comandá-los, os atores se afastavam lentamente dos ensinamentos que eram divulgados dentro do Estúdio. Ficavam cada vez mais distantes da vivência de que fala Stanislávski em seu Sistema, ao mesmo tempo em que caíam na sensibilidade exagerada e desnecessária ao teatro de que fala Diderot em $O$ paradoxo sobre $o$ comediante: "É a extrema sensibilidade que faz os atores medíocres; é a sensibilidade medíocre que faz a multidão dos maus atores" 
Em suas anotações feitas entre 1907 e 1908, Stanislávski resume bem esta questão. Para ele:

Os olhos são o espelho da alma e deve-se saber como mostra-los no momento certo e do jeito adequado à multidão. $\mathrm{E}$ ainda mais necessária é a imobilidade. Mas infelizmente a inquietação cênica, o medo da tosse na plateia ou o receio de fatigar o público e de perder sua atenção sua atenção fazem o ator forçar sua voz, exagerar o temperamento, usar todos os meios para atrair a atenção para si. O público vê os movimentos exteriores do ator e interessa-se por ele e por seus gestos. Sua inquietação muscular toca os nervos do público; entretanto é difícil nessa agitação perceber a vivência do ator e sentir a alma do poeta.

$\mathrm{O}$ ator deve chamar a atenção de uma maneira diferente. É necessário, antes de tudo, tranquilidade exterior e economia de gestos e movimentos. Isso dá possibilidade ao público de se interessar por sua vivência. Quanto menos o ator oferece visualmente, mais fortes devem ser a melodia e a música da alma. Mais claro e interessante deve ser o desenho psicológico do papel. Devem ser definidos e acentuados mais claramente seus componentes; as cores que preenchem esse desenho devem ser mais diversificadas. $\mathrm{O}$ desenho e sua realização devem ter mais lógica e coerência. Ao oferecer ao público os detalhes deste desenho claramente realizado, $o$ artista conquista não somente a atenção, mas também a alma de cada espectador. Quanto menos se oferece para os olhos mais se oferece para a alma. (STANISLÁVSKI, in: VÁSSINA, E.; LABAKI, A., 2015).

Se A festa da paz havia desagradado ambos os diretores por sua falta de delicadeza e excesso de agitação, ao mesmo tempo servia-lhes como instrumento de prática e reflexão, precisamente num ambiente onde experimentar e refletir acerca da arte teatral eram ações não apenas possíveis, como também necessárias desde o primeiro instante.

Tendo sido criado com o intuito de realizar uma pesquisa fundamentalmente prática e experimental, onde o ator era a figura central capacitada para a atividade criadora, o Primeiro Estúdio do Teatro de Arte buscava mais a realização de um trabalho de laboratório desvinculado de preocupações com o resultado final do que a apresentação diária de espetáculos. Se por um lado é óbvio que Leopold Sulerjítski e Konstantin Stanislávski buscavam fazer tudo bem feito e com certeza desejavam obter bons resultados toda vez que alguma peça por eles dirigida era encenada, por outro, era possível utilizar cada acontecimento alegre ou decepção como um instrumento para a evolução não apenas dos alunos, como também de suas próprias pesquisas. 
Com a criação do Estúdio, Stanislávski não olhava para a concretização de novas formas no que se refere às encenações teatrais, mas para a experimentação de seu Sistema por meio de exercícios práticos e sua aplicação na formação e crescimento do ator. De acordo com Rudnítski:

\begin{abstract}
A ocupação com o "Sistema" ao lado de toda a missão do estúdio evidenciava para Stanislávski aquilo que ele havia dito em sua conhecida carta a Meyerhold: "perdi completamente a fé em tudo o que serve aos olhos ou aos ouvidos em uma cena. Acredito apenas no sentido, na vivência e, principalmente, na própria natureza." (RUDNITSKY, 1990, p. 176). [Tradução nossa]
\end{abstract}

O que quer dizer que "O Estúdio, portanto, começou o seu trabalho em busca da verdade do sentimento, da verdade da emoção, menosprezando tudo o que serve 'aos olhos e aos ouvidos', i.e., a forma.” (RUDNITSKY, 1990, p. 176). [Tradução nossa]

O Primeiro Estúdio era este local onde a prática de exercícios, as improvisações, as conversas e o estudo de obras como a Khata ioga, serviam para ampliar a visão de mundo dos artistas e inseri-los em conceitos como vivência, vontade, círculo de atenção, "se" mágico e relaxamento dos músculos, alguns deles ainda em processo de descoberta. Isso fica ainda mais evidente se olharmos para o fato de que no plano de trabalho do Estúdio escrito em 1912, Stanislávski inscreve o desenvolvimento do Sistema como objetivo central. $^{39}$

Em 22 de setembro de 1914 Leopold Sulerjítski escreve em seu diário sobre a visita feita por Konstantin Stanislávski ao Estúdio no dia anterior. Após registrar em suas páginas a empolgação dos jovens estudantes, que no dia da visita conversavam sobre o Sistema, fazendo perguntas como "Por que não há um livro de tarefas?" ou "Por que até agora não se formou uma classe regular e cotidiana, na qual seriam produzidos estes exercícios tanto por atores jovens, quanto pelos velhos atores?", Sulerjítski aponta o caráter prático e experimental do Estúdio:

Os exercícios devem ser em separado:

- para o relaxamento dos músculos; - para a introdução de si no círculo;

- para a afirmação de si mesmo na fé e na ingenuidade; - para a habilidade de alcançar qualquer estado afetivo que seja, a

\footnotetext{
${ }^{39}$ Este plano encontra-se no livro Stanislávski, vida obra e Sistema (2015). Aqui Stanslávski inclui como primeiros objetivos do Estúdio: "1. Divulgar o Sistema. Figurantes, escola, atores. 2. Continuar a desenvolver o Sistema" (p.201)
} 
habilidade de alcançar aquela sensação que K. S. chama "eu existo" 40 diante de diversas existências ou de alguns conjuntos de acasos, etc.

- para estabelecer um objeto vivo;

- para a estimulação em si do estado de capacidade para o trabalho por meio de todos estes caminhos, etc.

Além disso, todas essas tarefas devem ser atraentes, devem ser interessantes para a vontade ${ }^{41}$, uma vez que conforme a expressão de K. S. sempre usada por ele: "À vontade criadora não se pode ordenar nada. A ela podemos apenas entusiasmar." [Tradução nossa].

Ao mesmo tempo em que aparentam ser as anotações feitas por um bom aluno que deseja não esquecer o que foi dito por seu mestre, estas frases de seu diário são reveladoras da importância definitiva que o Primeiro Estúdio teve para a construção gradual do Sistema e do quanto o Sistema vinha sendo aceito pelo grupo e empolgava os jovens aprendizes.

No decorrer da anotação de diário feita neste dia, Sulerjítski fala sobre as tarefas e exercícios realizados no Estúdio, sobre os conselhos que Stanislávski dava aos alunos e sobre a forma como o trabalho se dava em geral. Logo é possível perceber o quanto Stanislávski e Sulerjítski se complementavam em suas ideias. Enquanto Stanislávski diz, por exemplo, que as tarefas da atividade criadora devem ser atraentes à vontade criadora do ator,

Sulerjítski sugere a seguir em seu diário: "E eu ainda acrescentaria que talvez estas tarefas devessem ser ao mesmo tempo atraentes não apenas para o ator, mas também àquele que acompanha estes exercícios: o diretor ou o professor." (SULERJÍTSKI, 1970) [Tradução nossa].

Mas apesar de seu caráter voltado para o experimento, o jogo e o aprendizado, logo os alunos passaram a desejar também as encenações. Isto porque:

\footnotetext{
${ }^{40}$ Trata-se da sensação do ator de estar totalmente presente no momento da ação. Este termo funciona no "Sistema" como sinônimo para "vivenciar/experienciar e, na prática, todos os elementos do "Sistema" que relaxam o corpo e concentram a mente para a preparação do trabalho podem promover este estado chamado "eu existo". Uma vez que este termo tem como fonte o Yoga (no yoga "eu existo" é utilizado para definir a consciência que alguém tem de seu lugar na criação), seu uso no "Sistema" carrega conotações espirituais implícitas. (N.T.). [Informação retirada do dicionário de termos do Sistema. Material que me foi fornecido pela professora Maria Thais Lima Santos]

${ }^{41}$ No "Sistema", vólia corresponde a um dos três iniciadores da vida psíquica (vontade, sentimento e intelecto) e do processo criativo. O fato de "desejar", "ter vontade" de resolver o problema de determinada personagem é o que impulsiona o ator a entrar em ação. (N.T). [Ainda do dicionário de termos sobre o sistema]
} 
Quanto mais a juventude que se consolidava no Primeiro Estúdio se entusiasmava com os exercícios do

'Sistema', tanto mais intensamente os alunos de Stanislávski tinham vontade de atuar e de experimentar em público os métodos de aprendizado. No final das contas cada Estúdio teatral esconde em si uma potência do surgimento do teatro (RUDNÍTSKI, 1990, p. 180). [Tradução nossa]

Foi, portanto, a partir de um ímpeto natural dos alunos, que Stanislávski e Sulerjítski passaram a experimentar as encenações, inicialmente trabalhando com pequenos contos de Tchekhov e posteriormente com peças mais longas, como foi o caso de A festa da paz, sobre a qual aqui se falou. Tudo isso nesta nova célula que foi o Estúdio, surgida porque era preciso surgir e que graças à sua condução adequada serviu como uma espécie de ponte para os atores: um caminho onde cada passo era uma descoberta; e cada descoberta, uma forma de aprendizado.

\subsection{Que venha este diálogo!}

(Quarto onde viveu e trabalhou por muito tempo Leopold Sulerjítski. Terceiro andar do Estúdio do Teatro de Arte de Moscou. O cômodo é pequeno, estreito e comprido. Há nele apenas uma janela e uma mobília pobre e envelhecida, bastante simples. Vários livros. Uma mesa na qual está um caderno de anotações. Entra Leopold Sulerjitski. Senta-se e põe-se a escrever)

\footnotetext{
"Se me pedissem para exprimir em duas ou três palavras quais os traços fundamentais do estudante de teatro, eu diria: Se o senhor me disser que algo é difícil de se alcançar em um curto espaço de tempo, eu direi que isso deve ser posto como um ideal, como uma direção na qual devemos trabalhar, e quanto mais longe estiver, tanto mais energicamente nós devemos trabalhar sem desanimar ao ver nossa imperfeição. [...] $\mathrm{O}$ respeito ao homem e à arte, a atenção, a fé e a condescendência ao próximo, o rigor e a exigência consigo: eis os principais traços de um estudante de teatro." (SULERJÍTSKI, Arquivo do TAM) [Grifo do autor. Tradução nossa]
}

(Pausa. Leopold Sulerjítski lê sua anotação em voz alta. Larga o lápis. Em seguida fita o horizonte. Silêncio)

No arquivo do Teatro de Arte de Moscou há um caderno de anotações de Leopold Sulerjítski com escritos à lápis. Foi precisamente deste caderno, conservado sob o nome 
de "Esboços do projeto de organização interna do Primeiro Estúdio e seus objetivos éticos e artísticos", que extraímos a citação acima.

Esta reflexão, onde o trabalho, a persistência, o amor ao próximo e a exigência consigo mesmo aparecem em primeiro plano, é em grande medida representativa da busca artística e pedagógica de Leopold Sulerjítski ao longo de sua atividade no Primeiro Estúdio do TAM.

A vida de Leopold Sulerjítski foi um diálogo constante. E é chegado o momento de expormos aqui algumas das relações estabelecidas entre o seu pensamento e o de uma das figuras mais representativas da vida artística e cultural da Rússia no limiar do século XX: Lev Nikolaevitch Tolstói.

Desde o início das atividades realizadas no Estúdio, a influência de Lev Tolstói sobre Leopold Sulerjítski funcionou como uma unidade temática fundamental para o que foi ali desenvolvido. Neste diálogo que estabeleceram, Leopold Sulerjítski não apenas divulgava as obras e tratados de arte de Lev Tolstói entre seus alunos, como também se valia de elementos chave do tolstoísmo ${ }^{42}$ como forma de educar seus pupilos para a vida, no amor e na bondade.

A significação de Lev Tolstói para o teatro como um todo era imensa e Konstantin Stanislávski reforça isso ao escrever em Minha vida na arte :

Quando ele era vivo nós dizíamos: 'Que felicidade viver no mesmo tempo em que vive Tolstói!' E quando nos sentíamos mal de espírito e na vida e os homens pareciam feras, nós nos consolávamos com a ideia de que lá, em Iasnaia Poliana, vivia ele, Tolstói! E novamente queríamos viver.(STANISLÀVSKI, 1989)

E isto não foi diferente no que se refere ao Primeiro Estúdio.

Aquilo que Lev Tolstói trazia à tona em diversos de seus escritos e obras literárias - como quando diz, por exemplo, que "o ser humano deve conter suas paixões e cultivar dentro de si o amor; que o meio prático de alcançar isso é fazer aos outros aquilo que queremos que façam a nós" ${ }^{\natural 3}$ (TOLSTÓI, 2011, p. 203) ou quando termina seu conto

\footnotetext{
${ }^{42}$ Movimento ético e religioso surgido na Rússia durante a década de 1880 e mais tarde mundialmente conhecido sob o nome de Tolstoísmo. Alguns de seus traços centrais, utilizados também como paradigmas no trabalho do Estúdio são: uma certa atitude negativa em relação às classes superiores e à realidade capitalista, a afirmação da ressurreição moral do homem, o pacifismo e a crença nas forças do amor e da irmandade,

${ }^{43}$ In: O que é religião e em que consiste sua essência, escrito em 1902.
} 
Três perguntas (1903) dizendo que o mais importante é fazermos o bem aos outros "porque somente para isso foi dada a vida ao homem"44 (TOLSTÓI, 2011, p. 250) -, está explicitado nas anotações de Sulerjítski aqui citadas no início deste tópico, estando estas últimas profundamente marcadas pelo pensamento tolstoísta.

Desde a juventude Lev Tolstói criava uma série de regras para si, as quais ele desejava seguir rigorosamente. Em seus diários situados em 1847, por exemplo, já nos deparamos com este tipo de busca incessante pelo próprio aperfeiçoamento e um rigor absoluto para consigo mesmo. Trechos como "Não é suficiente afastar as pessoas do mal. É ainda necessário estimulá-las para o bem" , "Uma mudança no modo de vida deve acontecer. Mas é necessário que essa mudança não seja obra de circunstâncias exteriores, antes obra da alma" ou "o objetivo da vida do homem é contribuir, de todas as maneiras possíveis, para o desenvolvimento multilateral de tudo o que existe" 45 exemplificam claramente sua percepção de noções como dever, responsabilidade e busca pela perfeição.

Este desejo pelo aprimoramento pessoal persegue Lev Tolstói durante toda a sua vida. Até que em sua última fase ${ }^{41}$, quando o escritor se preocupa cada vez mais com o sofrimento do povo e passa a idealizar para si uma vida absolutamente despojada de riquezas, escreve um programa completo de seus objetivos de vida em um de seus diários $^{46}$. De acordo com este novo ideal de vida:

Para nós (riscado: deixar), isto é, eu, minha esposa e nossos filhos menores de idade, deixar, por enquanto, a renda de 2 a 3 mil rublos.Deixar por algum tempo, mas com a vontade de doála aos outros e se contentar com pouco, isto é, limitar, na medida do possível as nossas necessidades e dar mais do que receber, fazer todos os esforços possíveis para isso e ver nisso o objetivo e a felicidade da vida. (...) Educar os menores de tal maneira que eles se acostumem a exigir o mínimo da vida. Ensinar a eles aquilo que eles têm vontade de aprender. E não somente as ciências, mas as ciências e o labor. (...) Aos domingos, fazer

\footnotetext{
${ }^{44} \mathrm{O}$ conto, presente na coletânea "Os últimos dias", relata a busca de um tsar pela resposta para três questões que o perturbavam: "como saber a hora certa de cada coisa, como saber quais são as pessoas mais necessárias e como não se enganar ao julgar, entre todas as coisas, qual a mais importante.”(p. 246) Após diversas tentativas de responder à estas questões, o tsar se encontra com um eremita que em pouco tempo é capaz de lhe provar que: "a hora mais importante é agora, e ela é a mais importante porque nelas somos senhores de nós mesmos; e o homem mais importante é aquele com quem estamos agora, porque ninguém sabe se ele ainda estará com outra pessoa, e a coisa mais importante é fazer-lhe o bem, porque somente para isso foi dada a vida ao homem." (p. 250) [grifos do autor].

41 (BASSINSKI,2013) Capítulo V. Um novo russo.

45 Material já traduzido para o português. Ver: ERASSO, Natalia Cristina Quintero. Os diários de juventude de Lev Tolstói. Tradução e questões sobre o gênero de diário. Dissertação de mestrado, orientador: Noé Silva. São Paulo, 2011.

${ }^{46}$ Este programa de vida escrito por Lev Tolstói encontra-se já traduzido para o português e consta atualmente na obra Tolstói, A fuga do paraíso (2013), de Pavel Bassínski.
} 
almoços para mendigos e pobres, leituras e conversas. A vida cotidiana, a comida, a roupa (riscado: artes, ciências e outras deste tipo) - as mais simples (riscado: e acessíveis). Tudo o que é demais: (riscado: vender) o piano, a mobília, as carruagens vender ou doar. Somente se ocupar com tais ciências e artes que possam servir aos outros. O tratamento deve ser igual para com todos, do governo ao mendigo. O único objetivo é a felicidade de cada um e da família, sabendo que a felicidade consiste em se contentar com pouco e fazer o bem aos outros. (TOLSTÓI apud BASSINSKI, 2013, p. 233). ${ }^{47}$

Os ideais de bondade, igualdade, justiça e aperfeiçoamento moral de si mesmo expressos neste trecho de diário, são também ideais que marcam profundamente a vida de Leopold Sulerjítski e podem ser encontrados no decorrer de todo o seu trabalho com os alunos do Estúdio.

Menos de um ano depois da inauguração deste espaço a forte influência de Lev Tolstói via Sulerjítski já se fazia presente na escolha do repertório trabalhado pelos alunos. Sobretudo em obras como $O$ naufrágio do Esperança ${ }^{48}$ - do qual se falará no terceiro capítulo desta dissertação - e em A festa da paz $(1890)^{49}$, O grilo na Lareira $(1845)^{50}$ e $O$ dilúvio $^{51}$, estando estas últimas três peças ligadas por temas como a reconciliação, o perdão e o triunfo do bem.

É evidente que a proposta de criação do Estúdio não incluía a montagem de espetáculos. Desde o início, o que Leopold Sulerjítski desejava neste espaço fundamentalmente auxiliar a individualidade do ator a enxergar a beleza que está por trás da criação de um novo personagem, estando este seu desejo em total conformidade com o altruísmo e a visão que Sulerjítski tinha do teatro enquanto um meio poderoso de aproximar os homens. ${ }^{52}$ Era o ofício pedagógico, e não a atividade de encenador, o que mais o atraía para este espaço, já que "Sulerjítski queria alcançar a fonte da atividade criadora, queria encontrar o germe da ingênua atividade criadora (...)" (MÁRKOV, 1974). [Tradução nossa]

\footnotetext{
${ }^{47}$ Este ideal era algo impossível de se realizar, sobretudo devido a falta de apoio dos familiares.

${ }^{48}$ Peça do escritor Heijermans Herman (1864-1924)

${ }^{49}$ Título também traduzido por "A reconciliação".

${ }^{50}$ Peça baseada no conto de Charles Dickens (1812-1870) "The cricket on the hearth"

${ }^{51}$ Peça do escritor sueco Henning Berger (1872-1924)

${ }^{52}$ Ao tratar do papel fundamental de Leopold Sulerjítski no Teatro de Arte de Moscou, Slonim (1965, p. 129) diz: "Idealista de elevados objetivos estéticos y morales, buscaba la verdade y la inspiración artística en la comunión con la naturaleza, la sencillez em la vida y el amor activo. Tolstói dijo que Sulerzhitski tenia el gênio del afecto altruísta. Veia en el teatro um médio poderoso de acercar la gente y de provocar en ellos emociones sinceras."
} 
Mas apesar de o Primeiro Estúdio não ter como objetivo central a encenação resultante de um processo, esta hipótese não estava de todo excluída. De forma que em 1915 Sulerjítski já escreve sobre a seleção do repertório e a direção das peças e suas regras em seu caderno de anotações ${ }^{53}$ conservado atualmente entre os arquivos do Museu do TAM em Moscou. Em suas palavras:

\begin{abstract}
Considera-se diretor do estúdio cada um daqueles que conduziram sua peça até o ensaio geral, ainda que esta peça não vá a público. (...) Cada diretor tem o direito de pegar a peça que desejar e distribuir os papéis conforme sua vontade. A assembleia deve saber quem é, que peça escolheu e que intérpretes designou, mas sem direito à alteração ou proibição (nem aos papéis). A informação ao D. ${ }^{5449}$. É indispensável por seus dois objetivos: a) debater com os companheiros na reunião e defender com um ponto de vista artístico diante deles a razão de sua escolha; isto é indispensável a todos no sentido de adquirirem experiência na habilidade de distribuição dos papéis. Mas, se a voz que estiver apresentando sua peça não trocar nenhum intérprete nem mesmo após a deliberação, isso entrará em vigor e não poderá ser trocado por ninguém, exceto por K. $S^{55}$ - e b) Esta informação é indispensável para os objetivos organizacionais. A reunião da d[ireção] deve verificar se é possível a dado intérprete combinar tal papel com os já pegos por ele anteriormente. $\mathrm{O}$ d. S. deve ceder a esta apresentação o horário e o local entre os trabalhos do estúdio tanto para os ensaios, quanto para o espetáculo assim que estiver pronto. Quando os papéis estiverem distribuídos e o lugar e a hora forem encontrados, o presidente D.S. leva isto ao conhecimento de K.S. Quando K.S. assinar os papéis dá-se início ao trabalho com a peça. (SULERJITSKI, Arquivo do TAM) [Tradução nossa].
\end{abstract}

As regras estabelecidas no Estúdio permitiam claramente que os próprios alunos trouxessem sugestões para a realização das encenações. Leopold Sulerjítski, portanto, jamais impôs uma peça de sua escolha para ser encenada no Estúdio. Mas se isso, por um lado, exclui a possibilidade de o diretor ter incutido a ética tolstoísta através de escolhas pessoais no que se refere ao repertório, por outro, evidencia simultaneamente o quanto estavam todos atentos aos ensinamentos diários de Leopold Sulerjítski, já que por vontade própria levavam ao Estúdio peças baseadas via de regra no bem, no amor, na reconciliação e naquilo que de melhor o homem traz dentro de si.

\footnotetext{
${ }^{53}$ Trata-se do mesmo caderno citado anteriormente. Este caderno compreende diversos aspectos do Estúdio divididos em seções específicas. A seção da qual foram retirados os trechos a seguir traduzidos tem por título "Reunião da direção. Tipos de espetáculos". (Rejissiorskoe sobranie / tipy spektakei)

${ }^{54}$ P. C [letras do alfabeto cirílico]. Aparentemente refere-se a ele mesmo, diretor Sulerjítski que em russo se lê Rejissiour Sulerjitski)

${ }^{55}$ Konstantin Stanislávski.
} 
Talvez o melhor exemplo disso seja a peça $O$ grilo na lareira, criada a partir do conto homônimo de Charles Dickens. A ideia desta montagem surgiu para os alunos do Estúdio numa época em que, além de eles desejarem se aventurar por peças que até então desconheciam, o teatro russo vinha descobrindo novas possibilidades na adaptação da prosa, já que "os contos são dialogados, o autor narrador frequentemente concede a palavra ao personagem" (POLIAKOVA, 2006 p.184). ${ }^{56}$ [Tradução nossa]

A narrativa de Dickens gira em torno da trajetória de dois personagens centrais: a senhora Peerybingle, apaixonada pelo marido e pela vida simples que levam juntos; e o senhor Tackleton, comerciante de brinquedos rico e infeliz. Enquanto a primeira é uma mulher alegre, dona de um bom coração e se enche de alegria quando ouve o grilo cantar na lareira de sua casa, o comerciante Tackleton odeia o som dos grilos, costuma matá-los, e em geral é repudiado por todos os que o cercam - à exceção da jovem cega Berta, que por intermédio das mentiras contadas por seu pai Caleb, acredita ser ele um homem belo e bom.

Neste conto, temos acesso à seguinte descrição do personagem:

Tacketon, o comerciante de brinquedos, em geral conhecido por Gruff e Tackleton - porque este era o nome da empresa, ainda que Gruff tivesse sido adquirida há muito tempo, deixando apenas seu nome e, como alguns diziam, de acordo com o significado do dicionário, a sua natureza nos negócios Tackleton, o comerciante de brinquedos, era um homem cuja vocação tinha sido mal interpretada por seus pais e tutores. Se tivessem feito dele um usurário, um advogado afiado, um oficial de polícia ou um corretor da bolsa de valores, ele poderia ter desafogado suas más inclinações durante a juventude e depois ter tido o pleno controle de si mesmo nas transações de má índole, tornando-se , afinal, amável, por causa de um pouco de frescor e novidade. Mas, confinado e irritado na busca pacífica da fabricação de brinquedos, ele era um ogro doméstico que tinha vivido das crianças toda a sua vida e era o seu implacável inimigo. Ele desprezava todos os brinquedos; não teria comprado um só para esse mundo; fascinado, em sua malícia, em colocar expressões sombrias nos rostos de papelão dos fazendeiros que levavam os porcos para o Mercado, dos pregadores que anunciavam os advogados inconscientes, das mulheres mecânicas que cerziam meias ou cortavam tortas; e outras amostras do seu estoque para venda. Sua alma se revelava perfeitamente em máscaras terríveis, em caixinhas de surpresa com horríveis bonecos cabeludos de olhos vermelhos, em pipas

\footnotetext{
${ }^{56}$ As incríveis possibilidades oferecidas pela prosa tornaram-se ainda mais claras a partir da encenação de Os irmãos Karamázov realizada pelo Teatro de Arte de Moscou, em 1910. A partir daí, era visível que textos em prosa, se bem adaptados, teriam grande impacto sobre o público.
} 
vampirescas e em tumblers ${ }^{57}$ demoníacos que não se deitavam quietos e iam eternamente adianta para encarar assustadoramente as criancinhas. Eram seu único alivio e válvula de escape. Ele era grande em tais invenções. Qualquer coisa que sugerisse um pequeno pesadelo era deliciosa para ele.

(DICKENS) [Tradução nossa]

Este homem, descrito mais adiante também como sarcástico e antipático, deseja se redimir no fim do conto. $\mathrm{Na}$ esteira da personagem central da conhecida obra de Dickens, Um conto de natal, o senhor Tackleton percebe seus principais erros e pede perdão tanto para a senhora Peeryngle, por tentar voltar seu marido contra ela acusando-a de adúltera, quanto a todos os outros, por suas atitudes em geral:

\begin{abstract}
'Sra. Peerybingle!' disse o comerciante de brinquedos, 'eu sinto muito. Sinto mais agora do que sentia esta manhã. Tive tempo para pensar nisso. John Peerybingle! Estou muito amargurado; mas não consigo deixar de ser mais ou menos doce ao me encontrar cara a cara com um homem como você. Caleb! Esta pequena enfermeira inconsciente me deu uma dica na noite passada que me fez encontrar o caminho. Fico envergonhado ao pensar em quão facilmente eu poderia ter me unido a você e sua filha e que idiota miserável eu fui quando tomei-a [a sra. Peerybingle] por uma [vadia]. Amigos, todos, minha casa está muito solitária esta noite. Eu não tenho nem mesmo um grilo em minha lareira. Espantei-os todos. Tenham piedade de mim. Deixem-me participar desta festa feliz!' [DICKENS, Tradução nossa]
\end{abstract}

Este conto, com uma grande quantidade de diálogos e fortes evidências da capacidade de redenção do ser humano foi adaptado para a montagem teatral no Estúdio por Boris Sushkevitch e levado para o Estúdio em 1914, quando começou a ser dirigido por ele e Richard Boleslávski ${ }^{58}$ conjuntamente.

Quando começam a trabalhar com esta peça, Leopold Sulerjítski dá aos atores importantes lições, lembradas mais tarde por Evguieni Vakhtângov:

Nós conhecemos bem o seu sorriso, não precisamos ver para senti-lo.

Aí está você numa conversa sobre o "Grilo".

Seu lápis corre apressadamente sobre um pedacinho de papel, faz sinais involuntários e os risca.

\footnotetext{
${ }^{57}$ Tumblr - Brinquedo feito com uma base pesada e redonda e que por isso balança e se movimenta. (Fonte: The Heritage ilustrated dictionary of the Enqulish language International edition. Published by American Heritage Publishing co, ing)

${ }^{58}$ Richard Boleslávski será um dos grandes divulgadores das ideias de Stanislávski nos EUA futuramente.
} 
Eis que você largou o lápis e bateu com ele na mesa.

Isso quer dizer que você se resolveu por algo. Atentamente absorvido em seus pensamentos, outra vez tomou o lápis, fez um gesto qualquer de chamamento e nos disse: 'Não sei, talvez precisemos de uma aproximação particular com o 'Grilo', talvez precisemos começar os ensaios não como sempre fizemos, talvez o melhor seja irmos agora para o Monastério da Paixão, ficarmos lá em silêncio, voltarmos, acendermos a lareira, comermos ao seu redor todos juntos e lermos o

Evangelho ao lado de uma vela'.

Você nos dizia: 'Cheguem até o coração de Dickens, abram-no e então o coração do espectador se abrirá para vocês. Apenas em prol deste objetivo é que se mantém e deve ser encenado o

'Grilo'. A vida das pessoas é difícil, é preciso levar-lhes uma alegria pura.

Quando vocês pegarem uma peça para encenar, perguntem a si para que vão encená-la.'

Por acaso é possível esquecer este seu preceito enquanto o estúdio existir?

(VAKTHANGOV, 1970, p. 554-5) [Tradução nossa].

Quando Konstantin Stanislávski assistiu à encenação pronta, com toda a sua delicadeza e simplicidade, sentiu que havia nisso um grande trabalho por parte de Leopold Sulerjítski. Em Minha vida na arte, ele diz que Sulerjítski:

(...) entregou todo o coração a este trabalho. Deu-lhe muitos sentimentos elevados, força espiritual, bom vocabulário, convicções acolhedoras, belos sonhos com que alimentou todos os participantes, tornando o espetáculo inusitadamente íntimo e comovente. (STANISLÁVSKI, 1989, p.476)

A peça, apresentada em 24 de novembro de 1914 - justamente a época em que começava a estourar a Primeira Guerra Mundial -, não apenas foi extremamente bem acolhida por seu público, como também foi ela mesma acolhedora em certo sentido. Foi capaz de, durante sua realização, fazer com que os espectadores se esquecessem da tristeza e da falta de paz que havia lá fora.

Ao tratar de alguns aspectos relevantes deste espetáculo na monografia intitulada "O grilo na lareira", Nikolai Efros, um dos críticos teatrais mais destacados daquela época, nota que durante o espetáculo a ideia do "homo homini lupus est" logo foi substituída por um ideal de irmandade. A confusão, o desalento e as cinzentas preocupações do dia a dia foram deixadas de lado pelos cerca de 150 espectadores que assistiam à encenação, ocorrida pela primeira vez.

Por mais que a plateia houvesse entrado tensa no Estúdio, 
Teve início um milagre a partir do instante em que a negra escuridão foi abarcada por alguns sons musicais ingenuamente simples e um foguinho surgiu em meio à escuridão num canto à direita, revelando uma figura confusa, como que trêmula, não querendo tomar forma definida. Com um cochicho rouco e suave alguém da escuridão, pondo as mãos no quadril com raiva e ar de quem está ofendido pela chaleira que entrou em ebulição, pôs-se a falar sobre o grilo na lareira e sua bela canção, sobre o cocheiro John Peerybingle, que agora mesmo transportava uma encomenda pela nevasca e que tanto amava sua esposa e a "criancinha", e sobre a própria "criancinha". O murmúrio é suavemente difundido. E com estes cochichos, estes sons, os ruídos, as promessas e as recordações, começou a surgir através da couraça que os estados de ânimo e as inquietações forjavam ao seu redor em dias de guerra - um enorme fascínio na alma. Deixou de existir um certo gelo que havia no coração (...) (EFROS, 1918,p.7) [Tradução nossa].

Eis que o objetivo de Leopold Sulerjítski de aquecer os corações de seus espectadores se encontrava neste instante atingido. Realizava-se, ao menos por alguns momentos naquela pequena, íntima e acolhedora sala, o seu sonho de fazer da arte um instrumento de comunhão entre os homens, trazer bons exemplos aos espectadores, preencher com bons sentimentos os corações alheios. Pois ele "acreditava que, para derrotar o mal, bastava ressuscitar no homem as virtudes adormecidas; que o mundo poderia ser mudado com o bom exemplo e com paradigmas de altruísmo" (RIPELLINO, 1965, p. 198).

Como resultado da bela apresentação que fizeram, a repercussão da crítica teatral foi também extremamente positiva, gerando uma série de publicações a seu favor nos jornais da época. No jornal Rússkie Védomosti, publicado em 23 de dezembro de 1916 e conservado atualmente na filial da Biblioteca Lenin, o crítico N. A. Kabánov faz uma homenagem a Leopold Sulerjítski, falecido há poucos dias:

... não por acaso no Estúdio do Teatro de Arte, sua última obra, uma das primeiras encenações foi o dickensiano 'Grilo na lareira', e não por acaso inclusive, não muito antes de falecer ele sonhava com a encenação de 'Os sinos' de Dickens. Pois ele colocou tanto entusiasmo e amor, tanto trabalho na encenação de 'O grilo' e 'O grilo' em sua encenação teve igualmente um aparecimento tão extraordinariamente iluminado, ficando entre as encenações dos últimos anos em diferentes teatros, que desta maneira a humanidade e a sinceridade profundas de Dickens se harmonizaram maravilhosamente com as disposições de espírito de L. A. Sulerjítski, com a sua humanidade e sinceridade, com as 
suas observações sobre a tarefa essencial do teatro. (RÚSSKIE VÉDOMOSTI, 1916, p. 4) [Tradução nossa]. ${ }^{59}$

Mas se neste artigo o nome de Sulerjítski aparece como ponto bastante relevante para a montagem de $O$ grilo na lareira, não era este o hábito dos jornais daquela época, os quais focavam muito mais em aspectos do cenário, do figurino e sobretudo na atuação dos artistas do que em fazer jus ao papel desempenhado por Sulerjítski no Estúdio.

Em artigo publicado no Bírjivie Védomosti em 5 de maio de 1915 e igualmente conservado pela filial da Biblioteca Lenin, diz-se que:

\begin{abstract}
Há muito tempo não se via no teatro tal união, sinceridade e aplausos como ontem na estreia do jovem teatro de Arte. Há muito não se sentia essa cordialidade suave e afetuosa e a amistosa simplicidade que se reuniram no espetáculo (...) Muito obrigado, diretores do Estúdio, por recordar [...] o conto natalino de Dickens e encarná-lo em belas imagens cênicas." ${ }^{54}$ [Tradução nossa].
\end{abstract}

O nome de Leopold Sulerjítski, que já não era mencionado nos cartazes de suas montagens realizadas no Estúdio, sofre do mesmo mal neste artigo de jornal, onde não é mencionado sequer uma vez.

O fato de seu nome não estar nos cartazes do Estúdio é algo que não apresenta uma razão concreta, mas já é mencionado por Leopold Sulerjítski em seu próprio caderno de anotações quando ele trata das características das peças desenvolvidas pelo Estúdio: "Os cartazes desta peça são assinados por todos os diretores que tomaram parte neste trabalho, exceto pelo presidente D. S.: eu. (O pres. D.S., o dir. princip., o admin. do Estúdio jamais é colocado no cartaz)" (SULERJÍTSKI, Arquivo do TAM) [Tradução nossa]

Com o tempo, devido ao fato de seu nome não estar nos cartazes e sobretudo por ser Leopold Sulerjítski considerado por muitos um tolstoísta fervoroso, ocorre com ele uma espécie de apagamento na história do Teatro russo. Ou as obras escritas durante o período soviético não se referem a ele, ou trazem-no à tona sob uma visão bastante negativa e deturpada, já que nesta época qualquer nome ligado ao tolstoísmo era visto como prejudicial ao governo.

\footnotetext{
${ }^{59}$ Jornal conservado atualmente na Rússia, na filial da Biblioteca Lenin de Moscou. Núm.296 ${ }^{54}$ Também conservado na filial da Biblioteca Lenin. Núm.: I4825, p. 6.
} 
Ao tratar deste assunto e da relação do espetáculo "O grilo na lareira" com o tolstoísmo, Poliakova diz que:

\begin{abstract}
O espetáculo não se reduz ao ensinamento tolstoísta, mas este ensinamento germinou nele tal como cresce a partir do núcleo uma espiga carregada de grãos. O "Tolstoísmo" do final dos anos vinte até os anos noventa era como que um ponto de questionário que seria preferível não preencher. "Não fazia parte de nenhum partido, mas era seguidor do ensinamento de L. Tolstói..." A coluna do questionário que se refere ao nome do conde Tolstói não é menos perigosa do que o ato de reconhecer-se como revolucionário numa época em que a palavra de ordem da sociedade se tornou o pronunciamento de Górki: "Se o inimigo não se rende..." No teatro a palavra "tolstoísmo" é uma reprimenda, uma falta que deve ser superada. (...) Com o tempo o rótulo grudou com tamanha força no espetáculo [O grilo] que a sua ausência na resposta do estudante no exame, na exposição de um museu, num resumo de dissertação era obrigatoriamente observada. (POLIAKOVA, 2006, p.205-6) [Tradução nossa].
\end{abstract}

Se por um lado a influência exercida por Lev Tolstói foi uma das responsáveis pelo apagamento do nome de Leopold Sulerjítski ao longo de mais de cinquenta anos, por outro, foi em grande medida graças a ela que o Primeiro Estúdio floresceu, deu bons frutos e é lembrado até hoje como um espaço digno de nota na História mundial do Teatro.

O pensamento de Lev Tolstói não só esteve presente por trás da escolha das peças e da busca pelo aperfeiçoamento moral dos artistas, como também esteve em tudo o que dizia respeito à simplicidade das encenações e à necessidade de um trabalho enérgico e grande esforço na concretização dos espetáculos.

Paralelamente a Lev Tolstói, que buscava utilizar uma linguagem simples e clara em suas obras ${ }^{60}$, Leopold Sulerjítski buscava atingir o mesmo no que se refere ao cenário das encenações apresentadas pelo Estúdio.

Para cada uma das apresentações eram os próprios alunos que faziam os cenários. Mikhail Tchekhov (1970,p.608) conta em suas memórias como certa vez ele e Sulerjítski, após um longo dia de ensaio, passaram a noite colando e pintando os bonecos que

\footnotetext{
${ }^{60}$ Em um relato sobre a importância de Lev Tolstói para o Teatro de Arte, Nemiróvitch-Dântchenko já se refere à esta característica do escritor: "Tolstói era simples, profundamente verdadeiro, o extraordinário mestre das descrições e tão próximo, parecia que um pouco de esforço bastaria para escrevermos como Tolstói. O tempo todo, durante a leitura de suas obras, pulsava um pensamento: ah, como isso é magnífico e ao mesmo tempo simples. Eu também penso exatamente assim. Por que na minha cabeça não vieram essas imagens, essas situações, essas cores precisas, essas palavras claras e simples... Que coragem de ser tão simples!" (NEMIRÓVITCH-DÂNTCHENKO, 2013, p. 191).
} 
utilizariam como os brinquedos do senhor Tackleton em $O$ grilo na lareira. Ao falar do cenário de A festa da paz em seu relato, a atriz Sofia Guiatsíntova (2011, p.364) explica como tudo era simples, e como a cortina de pano, os artigos de mobília mais necessários e os pormenores casualmente escondidos criavam uma sensação de fidelidade aos costumes da época.

Sobre este assunto Rudnítski (1990, p. 182) diz que:

\begin{abstract}
A pobreza dos cenários contrastava nitidamente com a decoração dos espetáculos do TAM de então; o Primeiro Estúdio não tinha relações com pintores ilustres, e seus artistas (I. Ia. Gremislávski, M.B. Libakov, P. G. Uzunov) eram historiadores desconhecidos das artes plásticas. Com a ajuda destes artistas modestos criavase um esboço do Sistema com sinais distintivos pouco numerosos, suficientes para que surgissem a "impressão do quarto" ou a "impressão do bar", ou a "impressão da oficina". [Tradução nossa].
\end{abstract}

Todos os espetáculos do Primeiro Estúdio apresentaram exclusivamente "impressões" de interiores. As encenações eram realizadas em salas, num ambiente de encantadora intimidade, onde atores e espectadores já não estavam mais separados pela balaustrada e nem pela ribalta. Esta proximidade agia sobre o espectador de tal forma que este tinha a impressão de estar no mesmo cômodo das personagens e de apenas por acaso estar assistindo ao desenrolar de toda uma encenação. Com isso:

... a "quarta parede", obrigatória para os primeiros espetáculos do TAM, aqui não possuía a integridade e a indecifrabilidade sagradas. Como já foi dito, o ator podia chegar bem junto do espectador da primeira fileira. A linha convencional da quarta parede neste instante rompia. Surgia de imediato a possibilidade de relações com a plateia: não os jogos com ar desafiador de coragem à beira do proscênio, não as convenções especialmente sublinhadas, as quais Meyerhold tanto amava e que traziam consigo a sensação de agudeza do teatro, mas, ao contrário, o mais discreto e sincero desabafo de suas recônditas vivências para a plateia, publicamente. (RUDNÍTSKI, 1990, p. 182) [Tradução nossa]

Ao longo do tempo em que esteve no Estúdio, Leopold Sulerjítski aliou esta simplicidade ao trabalho enérgico que menciona em seu caderno de anotações citado no início deste tópico da dissertação.

Leopold Sulerjítski compreendia o trabalho como algo absolutamente necessário para o desenvolvimento do ser humano e da união entre os homens, uma questão a que 
Lev Tolstói também faz referência em seu conto $O$ trabalho, a morte e a doença (uma lenda) (1903). Trata-se de uma lenda existente entre os índios da América do Sul e segundo a qual Deus teria criado os homens inicialmente dando a eles uma vida ociosa, sem a necessidade de trabalho, casa, roupa ou comida. Com o tempo, ao observar que em decorrência de sua ociosidade cada qual pensava apenas em si mesmo, "Deus fez com que ao homem fosse impossível viver sem trabalho. E para que não padecessem de frio e de fome, tiveram de tecer roupas, arar a terra, semear e colher frutas e grãos." (TOLSTÓI, 2011, p.243). Mas a criação do trabalho, ao invés de unir os homens como era a intenção de Deus, fez que estes se distanciassem, criassem grupos e tentassem atrapalhar e tirar os trabalhos uns dos outros. O mesmo ocorreu com as demais criações de Deus (as doenças e falta de consciência sobre a hora final), com as quais ele esperava juntar a humanidade, mas que sem querer continuava a afastá-la. Foi quando Deus tomou uma decisão:

(...) disse a si mesmo: se nem assim é possível fazer os homens compreenderem em que consiste sua própria felicidade, eles que se arranjem com seus próprios sofrimentos. E Deus abandonou os homens.

Sozinhos, os homens viveram muito tempo sem entender o que podiam e deviam fazer para ser felizes. Apenas nos últimos tempos alguns homens começaram a entender que o trabalho não deve ser um temor para alguns, nem um castigo para outros, ao contrário, deve ser comunitário, agradável e unir os homens. (Ibidem, p.245)

Por acreditar na importância do trabalho e da persistência é que Leopold Sulerjítski era incansável no que se refere ao Estúdio. Por mais de uma vez seus alunos relatam casos em que Sulerjítski se focava no trabalho a ponto de esquecer todo o resto ao seu redor. A atriz Serafima Bírman (1971, p.42) conta como certa vez na escola de Adáchev, os atores ensaiavam, quando teve início um incêndio ali perto. Apesar de olhar pela janela e se dar conta disso, Leopold Sulerjítski imediatamente se voltou aos atores dizendo: "Bem, vamos ensaiar mais uma vez este pedacinho". E os alunos voltaram a ensaiar, agora não apenas sob a iluminação elétrica da sala, como também sob a luz provocada pelo clarão do incêndio, cada vez mais forte. E sem que se dessem conta do horário, a noite chegou. E eles todos ainda ensaiavam ali.

A dedicação total ao Estúdio bem como o trabalho incessante em busca dos objetivos propostos, fizeram com que por mais de uma vez Stanislávski repreendesse Sulerjítski, pedindo que ele não se desgastasse tanto, que não carregasse todo um fardo 
para si. Olga Sulerjítskaia (1970, p.545) conta como um dia, estando diante de uma carta de Stanislávski com um pedido como este, Sulerjítski sofria, ao mesmo tempo em que dizia a ela "Ele escreve para eu não trabalhar muito... Mas como eu posso não trabalhar assim, se me resta tão pouco tempo de vida.”. [tradução nossa]

Leopold Sulerjítski se foi para sempre, deixando para trás inúmeras anotações em cada um dos cerca de 50 livros que compunham sua biblioteca. Anotações estas que são comentadas por Vakthangov em suas recordações.

VAKTHÂNGOV: "E por toda parte, mesmo nas menores linhas, você apela para a misericórdia, para o amor, para a sensibilidade e as boas relações. Cada frase ou anotação sua era guiada pelo coração" ${ }^{61}(1970$, p.556) [tradução nossa]

Como a anotação que se segue. Que além de possuir as características apontadas por Vakthângov, evidencia o impulso para o trabalho de que acabamos de falar:

Se todas as paredes, se todo o estúdio estiver impregnado pelo trabalho utilizado para o seu aperfeiçoamento, vocês verão como ele terá valor e será estimado por todos e como cada um se sentirá ofendido com qualquer comportamento negligente e superficial." (SULERJÍTSKI apud VAKTHANGOV, 1970, p. 556) [Tradução nossa].

\subsection{E que a arte voe rumo ao infinito!}

\subsubsection{Uma pequena liberdade}

Sim. Era necessário trabalhar.

Mas quem foi que falou em fazê-lo individualmente?

Como se o Estúdio fosse um barco, não havia sentido no trabalho solitário de um homem só. Era preciso que todos rumassem na mesma direção, que desejassem o mesmo destino e estivessem preparados para enfrentar juntos as tempestades com que o barco da arte, às vezes, se depara em meio ao oceano.

Leopold Sulerjítski foi marinheiro. Um homem apaixonado pelo mar desde a primeira vez que entrou em contato com suas águas. Ele sabia claramente que qualquer viagem traz consigo o desejo de chegada a um ponto final. Mas ao se aventurar pela arte, compreendeu não ser suficiente escolher uma boa ilha na qual aportar. Era preciso, mais

\footnotetext{
${ }^{61}$ Estas anotações foram encontradas nos livros da pequena biblioteca de Leopold Sulerjítski após a sua morte.
} 
do que isso, que a viagem fosse boa, alegre. E que os homens que faziam parte do barco se respeitassem mutuamente.

Se é possível aqui tomarmos a liberdade de comparar sua vida artística a uma viagem de barco, então dividamos esta comparação em dois aspectos que se complementam simultaneamente: enquanto o ponto de chegada era para ele a realização da comunhão entre os homens (sua visão estética), a maneira de portar-se dos companheiros de viagem (a ética) era o que levaria o barco adiante em seu objetivo, impedindo-o de afundar em meio ao mar.

\subsubsection{Da relação entre Ética e Estética dentro do Estúdio}

A palavra "estética", tal qual a conhecemos hoje, surge a partir da publicação da obra Aesthetica (1750) escrita pelo filósofo alemão Baumgarten. Embora muito antes importantes pensadores como Platão, Aristóteles, Plotino, Santo Agostinho e São Tomás de Aquino já houvessem discutido temas referentes a esta disciplina filosófica ${ }^{62}$, é apenas com Baumgarten que a estética é oficialmente batizada, passando a conquistar o moderno sentido de "relativo ao belo e à arte".

A visão que se teve posteriormente segundo a qual a estética seria a ciência do Belo, é atualmente considerada ultrapassada. Enquanto em algumas obras sobre este assunto ainda encontramos definições que a apontam como uma "disciplina, que tem por objeto o belo e suas manifestações” (SANTOS, M. ,1966, p. 20), Etienne Souriau (1973, p. 29-30) diz que esta visão é divulgada por aqueles que falam de Estética sem uma competência adequada. Para ele:

A menos que se admita, à maneira platônica, um Belo absoluto, objeto de intuição intelectual universal certa, o Belo não é um fato objetivo, positivamente discernível e capaz de dar consistência e solidez ao seu estudo. (...) o Belo não é absolutamente o único epíteto que possa caracterizar esteticamente um objeto. Vimos que desde o romantismo o

\footnotetext{
${ }^{62}$ Em Chaves da Estética, o antigo professor na Sorbonne Etienne Souriau (1973, p. 1-11), discute as ideias centrais de cada um destes pensadores, algumas das quais merecem ser aqui sucintamente mencionadas. De acordo com o autor, Platão fala em algumas de suas obras, por exemplo, sobre temas como o Belo, o Bem e o Verdadeiro, que se encontram interligados hierarquicamente, sendo possível chegar ao Bem por meio da contemplação estética. Aristóteles trata da arte enquanto instrumento socialmente benéfico, pois purifica, enobrece e harmoniza as paixões. Plotino fala a respeito do artista como alguém que representa as Ideias e de forma alguma como um imitador dos aspectos sensíveis do mundo. Para Santo Agostinho é possível aproximarmo-nos de Deus por meio da Beleza. Por fim, São

Tomás de Aquino caminha pelo racionalismo estético, revelado em expressões como "a correta razão da coisa a ser feita".
} 
Sublime e o Belo foram considerados como categorias estéticas igualmente válidas e concorrentes; desde o romantismo se enumerou muitos outros valores estéticos igualmente consideráveis: trágico, dramático, bonito, gracioso e assim por diante. Desta forma, o Belo, como objeto da estética, se apresenta fracionado, e, por isso, se anula...

Atualmente considerada reducionista e ultrapassada, tal perspectiva abriu espaço para a definição de Estética como a ciência geral da arte. Sustentada em sua maior parte por uma série de estetas alemães, esta nova teoria encontrou em Lev Tolstói um de seus fundadores e principais defensores. Por meio de sua obra $O$ que é arte? (1898), Lev Tolstói não apenas repensa o papel da arte como um todo, mas também levanta questões referentes à finalidade da arte e ao conceito da palavra "belo", a qual diferentemente do que muitos pensam não carrega dentro de si o conceito de "bom". De acordo com Lev Tolstói (2002, p. 37):

Um homem, um cavalo, uma casa, uma vista, um movimento, podem ser belos, mas sobre ações, caráter, música, podemos dizer que são bons, se gostamos muito deles, ou não bons se não gostamos; só podemos dizer 'belo' daquilo que é agradável a nossa visão. De forma que a palavra e o conceito 'bom' abrangem dentro de si o conceito 'belo', mas não vice-versa: o conceito 'belo' não cobre o conceito 'bom' (...) Em todas as línguas europeias, a língua daqueles povos entre os quais a doutrina da beleza como essência da arte se espalhou, as palavras beau, schon, beautiful, bello, conquanto mantenham o sentido de beleza da forma, também passaram a significar 'bom-dade' - ou seja, passaram a substituir a palavra 'bom'. (...) Evidentemente, que esse novo significado com o qual o pensamento europeu dotou a beleza está começando a ser usado pela sociedade russa também. (...) É necessário ler alguma coisa sobre estética para formar uma ideia pessoal da diversidade de julgamentos e da terrível indefinição que reina nessa esfera e opinião, para não confiar nas palavras de outrem nesse assunto tão importante.

Após tratar detalhadamente das várias definiçõoes da palavra beleza existentes desde a publicação da obra de Baumgarten ${ }^{63}$, Lev Tolstói percebe o quanto o fato de este conceito estar na base das definições de arte afetou imensamente seu entendimento.

E conclui que:

A imprecisão de todas essas definições resulta do fato de que em todas elas, tal como nas definições metafísicas, o objetivo da arte

\footnotetext{
${ }^{63}$ Todo o terceiro capítulo de $O$ que é arte? é dedicado a esta questão.
} 
está colocado no prazer que extraímos dela, e não em seu propósito na vida do homem e da humanidade.

Para definir arte com precisão, devemos antes de tudo parar de olhar para ela como veículo de prazer e considerá-la como uma das condições da vida humana. Ao considerá-la dessa forma, não podemos deixar de ver que a arte é um meio de comunhão entre as pessoas.

Cada obra de arte faz com que aquele que a recebe entre em um certo tipo de comunhão com aquele que a produziu ou está produzindo e com todos aqueles que, simultaneamente ou antes ou depois dele, receberam ou irão receber a mesma impressão artística. (Ibidem, p. 72-3).

Não sem fundamento Lev Tolstói se tornou exemplar no sentido de desembaraçar a Estética com relação às dificuldades existentes no que se referia à aplicação de seus epítetos (SOURIAU, 1973, p. 40). De forma que graças a ele a Estética passou a ser pensada enquanto ciência universal da arte, carregando consigo a partir de então a questão da reflexão. O que talvez tenha levado Etienne Soureau a definir a Estético no início de seu livro como "uma forma do pensamento reflexivo. É a mente humana refletindo sobre sua própria atividade, por meio da qual criou todos os templos, todas as estátuas, todas as pinturas, todas as melodias, todas as sinfonias, todos os poemas..." (Ibidem, p. 1).

Se Lev Tolstói tinha plena consciência de que o belo por si só não gera senão a satisfação em si mesma, tal tipo de consciência esteve também presente por trás de todo o trabalho artístico que Leopold Sulerjítski realizou. Seguindo os passos de seu mestre, Sulerjítski via na arte o propósito de unir as pessoas, de fazê-las viverem em comunhão umas com as outras, transmitindo sentimentos e vivências. E o teatro, inserido neste contexto, era para ele um caminho, talvez o mais eficaz, para se buscar relações humanas profundas, e uma união verdadeira, fundada em bases éticas sólidas.

Este seu conjunto de ideias, norteador das atividades dentro do Primeiro Estúdio, é apontado por Konstantin Stanislávski em suas recordações sobre Sulerjítski:

Por que ele amava tanto o Estúdio? Porque realizava um dos fins mais importantes da sua vida: unir os homens, encontrar uma atividade comum, fins comuns, lutar contra a vulgaridade, o ódio e a injustiça, servir ao amor, à nobreza, à beleza e a Deus. (STANISLÁVSKI, 1970) [Tradução nossa]. 
Em seu trabalho, Sulerjítski se esforça pedagogicamente para afastar o teatro da limitação de ser uma mera atividade de entretenimento, livrando-o daquilo que Lev Tolstói critica tão vorazmente em seu livro $O$ que é arte? De maneira que boa parte de seu trabalho se concentra em auxiliar os alunos do Estúdio a revelarem a essência que carregavam dentro de si, a revelarem o humano, a abrirem seus corações para os espectadores.

Mas tudo isso, sem jamais excluir o belo de sua busca.

Em suas recordações sobre Leopold Sulerjítski disponíveis na coletânea de Poliakova, o artista V. S. Smychliáev (1970, p. 580) evidencia esta situação quando diz que:

Em cada atividade sobre o Sistema ele [Sulerjítski] falava não apenas sobre a arte independente do ator, mas ele via no ator um homem vivo. E este "homem vivo" era o principal objetivo de preocupação. Não um pequeno-burguês autossuficiente, não um diretor fantasticamente humorado, mas corajoso, belo, com um pensamento sensato e razoável, uma simplicidade encantadora, em suma, um homem desenvolvido harmonicamente, eis como deveria ser o ator. E além disso, este ator deve falar apenas sobre o belo. Sempre chamar as pessoas para assuntos belos, não dar a elas a possibilidade de mergulhar no lodo da mesquinhez e da mentalidade pequeno-burguesa. A arte do ator é um enorme meio de educação e elevação das pessoas [Tradução nossa].

Como vemos neste trecho, Leopold Sulerjítski buscava e desejava encontrar o belo dentro da arte. O que não significa de forma alguma que esta busca excluísse outras questões como o desejo pela união, pela moral ou pelo bem. Ora, a bem da verdade, o belo e o bem podem até não estar necessariamente interligados - como prova Tolstói em sua obra $O$ que é arte? - , mas isso não quer dizer também que ambos tenham necessariamente de se contrapor. Prova disso é aquilo que filósofos como Immanuel Kant (1724-1804) ou Friedrich Schiller (1759-1805) ${ }^{64}$ - os quais precisamente se encontravam inseridos no Romantismo alemão do século XVIII e que defendiam o belo como o principal objetivo da arte -, dizem em dois de seus textos.

No texto "O estado estético do homem" ${ }^{65}$, por exemplo, Schiller aborda a importância que a beleza tem na vida do ser humano e diz que "A beleza conduz o homem, que só vive pelos sentidos, ao exercício da forma e do pensamento; a beleza

\footnotetext{
${ }^{64}$ Johann Christoph Friedrich von Schiller, mais conhecido como Friedrich Schiller, foi um poeta, filósofo, médico e historiador alemão.

65 "El estado estético del hombre" In: Antología. Textos de estética y teoria del arte. Coletânea de textos sobre arte organizada por Adolfo Sánchez Vázquez. Este texto de Schiller presente na coletânea corresponde a duas cartas (XVIII e XXII) do livro "La educacion estética del hombre".
} 
devolve o homem, submerso na tarefa espiritual, à experiência com a matéria e o mundo sensível." ${ }^{66}$ (SCHILLER, 1978, p. 21) [Tradução nossa]. Enquanto isso, Kant diz em "A bela arte" ${ }^{\natural 7}$ que existem dois tipos de arte, a bela e a agradável, e que enquanto a agradável tem por finalidade o gozo sem reflexão,

\begin{abstract}
A arte bela, ao contrário, é um modo de representação que por si só já está de acordo com uma finalidade e que, mesmo sem esta finalidade, fomenta, no entanto, a cultura das faculdades do espírito para a comunicação social.

A comunicabilidade universal de um prazer já traz consigo em seu conceito a condição de que não deve ser um prazer do gozo nascido da mera sensação, mas da reflexão, e assim a arte estética, como a bela arte, é de tal índole que tem por medida o juízo reflexivo e não a sensação dos sentidos. (KANT, 1978, p. 69). [Tradução nossa]
\end{abstract}

Se olharmos para a obra monumental do próprio Lev Tolstói bastará meia página para percebermos que ele próprio criava textos belíssimos, e que, portanto, não poderia condenar a existência da beleza dentro de uma obra de arte. Muito pelo contrário. O que Lev Tolstói repudiava, era não a obra de arte bela, mas a obra de arte criada apenas em função do que ficou conhecido como a arte pela arte.

A noção de que a arte teatral deveria ter um resultado belo - e não o belo como resultado, que fique claro -, foi aproveitada por Leopold Sulerjítski desde o início de seu trabalho como assistente no Teatro de Arte de Moscou.

Quando Sulerjítski é encarregado de acompanhar a montagem de $O$ pássaro azul que deveria ser realizada em Paris com a mesma encenação que havia sido apresentada pelo TAM em Moscou, se enfurece diante de uma série de problemas que parecem impedir que exista um bom resultado final. Em carta escrita a Stanislávski em 21 de fevereiro de 1911, ele diz com todas as letras o quanto está farto de tudo:

\title{
Caro Konstantin Serguéevitch,
}

Se o senhor apenas soubesse o que fazem aqui!

Como tudo isso é miserável. Me atormentaram, me arruinaram de uma tal forma, que não me lembro quando me senti assim. Nada foi feito.

\footnotetext{
${ }^{66}$ Além disso, de acordo com Schiller, quando nos entregamos ao gozo da verdadeira beleza entregamonos ao mesmo tempo à seriedade e ao divertimento, ao repouso e ao movimento, à condescendência e à reação, ao pensamento absoluto e ao instintivo. Tal completude, a qual conduz ao ilimitado e gera grande liberdade espiritual, faz da atividade estética a mais proveitosa tanto para o conhecimento quanto para a moralidade humana.

67 "El arte bello"
} 
As coisas que lhes encomendei ainda em dezembro só hoje é que foram encomendadas por eles (como os figurinos das estrelas); o espetáculo é dia 26 e ainda não ensaiaram aqui, das roupas eu ainda não vi sinal, os cenários da Noite foram refeitos (escreveram Pano de fundo) e por isso os fantasmas não estão passando; a corrente elétrica está fraca, não há disciplina, ninguém escuta nada, as encomendas não estão se cumprindo, todos mentem, enganam e tudo por causa de economia. Os atores são trocados incessantemente. Contratam atores baratos para os ensaios de propósito, para pagar menos, e três dias antes trocam, contratam os "grandes artistas", que são uma porcaria tão grande quanto os baratos, só gritam mais alto, sapateiam e agitam os braços.

E eu sou obrigado a ensaiar com todos eles. Trocaram dois gatos e agora, desde anteontem, há um novo. Amanhã chegará uma segunda fada já que desistiram desta, uma terceira Constipação ${ }^{68}$, etc., infinitamente. Canalhas e patifes! Se não houvesse responsabilidade em nosso teatro há muito eu teria dado uma cuspida e fugido daqui. As vulgaridades se introduzem incessantemente. E tudo isso se faz com o nome de

Maeterlink ${ }^{69}$ : "Maeterlink disse", "Maeterlink quer assim"; e eu silencio. O que é que se pode dizer contra o autor? Mas ele está sentado bem aqui e diz o que é necessário, que tudo seja mais vivo, que falem mais depressa, que façam mais alegremente a dança popular de roda no primeiro ato - que o público francês ama -, que seja iluminado e alegre, etc., (...) (...) estão armando um berreiro, fizeram uma certa casa de feras e um circo, e tudo de que os atores tanto gostavam em nossa encenação, tudo o que eu tinha conseguido entusiasmar neles e a nobreza, qualquer que seja, que eu tinha conseguido criar em cena, tudo isso agora é pisoteado com extravagâncias de palhaços circenses; nós ladramos, miamos, uivamos numa briga ordinária.

É insuportável de ver. (...)

Um inferno e uma infâmia!

Não acredito que o público de Paris goste desta coisa ordinária e de mau gosto que dela estão fazendo os atores parisienses sob a direção do autor e de Rejan. Vi aqui uma troupe belga que já representou 350 vezes uma comediazinha curta, e vejo que os franceses compreendem maravilhosamente o fino gosto e a nobreza da atuação, o fino humor sem o gesto, sem a afetação e as palhaçadas e tudo aquilo que Leblan e Rejan introduzem na peça e que chamam de público teatral parisiense, já é um mau gosto pessoal de ambas, só isso. (....) (SULERJÍTSKI, 1970, p. 4767) [Tradução nossa].

É evidente a partir daí que a falta de um conjunto de regras denigre o ambiente teatral e neste caso propicia o despontar de um péssimo resultado, sem valores estéticos

\footnotetext{
${ }^{68}$ Assim como o gato e a fada, a Constipação é uma das personagens desta peça. (N.T.)

${ }^{69} \mathrm{O}$ próprio autor da peça, que havia ficado encantado com a montagem realizada em Moscou, estava auxiliando na direção da peça em Paris.
} 
como a harmonia, a profundidade, a leveza, a sensibilidade e a beleza ${ }^{70}$. Era este tipo de resultado justamente algo muito diferente daquilo que os integrantes do TAM desejavam para seu teatro.

Ademais, Leopold Sulerjítski sofre nesta carta não apenas pelo resultado, isto é, não apenas pelo fato de o grupo ferir a beleza de uma peça que por si só já carregava uma estória um tanto poética ${ }^{65}$, mas sobretudo pelo fato de o grupo parisiense levar o ordinário ao público, pela falta da ética dentro do ambiente teatral, a carência de regras que deem certo sentido ao trabalho criador realizado e garantam o equilíbrio e a felicidade dos envolvidos neste processo.

Quando falamos em ética (do grego, ethos), estamos nos referindo a um dos mais importantes temas da filosofia, distribuído em três diferentes dimensões: 1) o conjunto de práticas, hábitos e costumes de um determinado povo; 2) o conjunto de preceitos que estabelecem e justificam valores e deveres (ética em um sentido normativo); e 3) a ética em seu sentido reflexivo ou filosófico, cujo centro está na responsabilidade, nos princípios e em questões semelhantes que visem discutir a natureza e as bases dos Sistemas e das práticas, analisando valores e conceitos que as fundamentam (MARCONDES, 2015, p. 10).

Neste último sentido, Sulerjítski estaria em sua carta gerando uma séria reflexão acerca do Sistema de trabalho presente no teatro de Paris, sem aceitar os valores ali estabelecidos.

Em Stanislávski a busca por uma interligação entre ética e estética foi crucial desde o início. Quando reflete acerca da ética em suas anotações ${ }^{71}$, Konstantin Stanislávski igualmente compreende a necessidade de um ambiente de trabalho ordenado e saudável, já que sem isso é impossível vivenciar a experiência teatral. Para ele:

O artista, assim como os demais cidadãos, está obrigado a conhecer as leis da ética social e subordinar-se às mesmas.

A ética artística é a ética profissional da gente do teatro. Suas bases são as mesmas que as da ética social, mas elas deverão

\footnotetext{
${ }^{70}$ Estes valores são citados por Mario Ferreira dos Santos como valores estéticos exemplares em Convite à Estética (1966) ${ }^{65}$ Trata-se da estória de dois irmãos pobres, Titil e Mitil, os quais guiados por uma fada e pela "alma" de objetos e animais conhecidos seus (o açúcar, o leite, o pão, o gato e o cachorro) partem em busca daquele que supostamente lhes trará a felicidade, isto é, o pássaro azul. Mas toda vez que o pássaro se encontra em suas mãos, é como se a felicidade escorresse de seus dedos e as crianças tem de recomeçar sua busca sem fim. Esta peça conta com uma tradução para o português feita por Carlos Drummond de Andrade e devidamente indicada na bibliografia deste trabalho.

${ }^{71}$ Estas anotações encontram-se disponíveis em espanhol, fazendo parte da coletânea "Trabajos teatrales", ainda não traduzida para o português.
} 
adaptar-se às condições da nossa arte. Estas condições são diversas e complexas.

A primeira delas se apoia no coletivo de trabalho do poeta, do diretor, do artista, dos cenógrafos, dos músicos, dos dançarinos, dos maquiadores, dos figurinistas e de todo o restante do pessoal teatral.

Cada um deles separadamente é um criador independente em seu campo de ação dentro da nossa arte. Tomados conjuntamente estão todos ligados entre si pelas leis da harmonia artística e pelo objetivo comum e final a todos que é a criação. Para pôr em ordem o trabalho de muitos criadores e cuidar da liberdade de cada um deles em particular são necessários princípios morais que promovam o respeito para com a criação alheia e que mantenham o espírito de camaradagem no trabalho comum, que cuidem da liberdade de criação própria e alheia e que morigerem o egoísmo e os instintos nocivos de cada um dos trabalhadores do coletivo tomados individualmente.

A ética artística cria estes princípios morais adaptando-se às condições de nossa arte. (STANISLÁVSKI, 1986, p. 85-6). [Tradução nossa]

Compreendendo a relevância que o campo ético possuí para o desenvolvimento de uma arte coletiva como o teatro, Konstantin Stanislávski e Leopold Sulerjítski redigiram um documento no qual constava a organização ética e estética do Primeiro Estúdio, bem como todas as demais questões relativas à administração e às reuniões, que deveriam ocorrer mensalmente. Este documento encontra-se atualmente entre os arquivos do RGALI $^{72}$ com algumas anotações manuscritas e possui sua versão definitiva e completamente datilografada arquivada no Museu do Teatro de Arte de Moscou ${ }^{73}$.

Em ambas as versões, Leopold Sulerjítski é descrito desde a primeira página como o assistente de Stanislávski, diretor de ideias, administrador e responsável pela parte moral do Estúdio. No décimo oitavo tópico deste documento, ao tratar especificamente da parte ética, Leopold Sulerjítski escreve que:

Os membros do Conselho do Estúdio devem se lembrar e mais frequentemente recordar um ao outro que eles receberam para si um serviço do Estúdio e respondem não só perante os integrantes do Conselho, como também diante da própria concepção do Estúdio; do Estúdio, que no campo da arte teatral está constituído em prol de buscas, revelações e realizações das mais altas neste campo e que em sua vida espiritual tomou por base o princípio mais elevado da alma humana; devem recordar-se que se é possível não se orgulhar, mas se alegrar com a eleição no

\footnotetext{
72 Nesta biblioteca consta no arquivo o nome de Evguêni Vakthangov como redator do documento. (Número do arquivo: 1990/2/4)

${ }^{73}$ No museu do TAM consta o nome de Sulerjítski como redator. (Número do arquivo: 13613/1)
} 
Conselho do Estúdio, então não há um grande erro e um grande crime diante da consciência do Estúdio, como seria um crime sentir-se o superior e comandar compreendendo a própria situação como a de chefe dos demais. Da mesma forma que cada membro da administração ou que dirige uma parte separada da vida do Estúdio deve lembrar-se de que se o escolheram então ele assumiu um serviço, mas não um poder. O Conselho do Estúdio é obrigado a acompanhar para que a sede de poder não cresça também naquele que advertir a mínima inclinação junto a seus membros, devendo fazê-lo por respeito e atenção para com este. O poder é o inimigo mais terrível do Estúdio, que irá perturbar o seu trabalho sob todos os aspectos, tanto no artístico quanto também no moral e no social. (...) Menos regras e leis, mais respeito ao homem e à arte dentro dele, mais atenção e confiança nos outros, severidade e exigência consigo - eis a base das relações dos membros do Estúdio. (SULERJÍTSKI, 1915).[Tradução nossa]

Encontra-se neste documento um conceito difundido por Stanislávski desde a inauguração do Teatro de Arte de Moscou, já que um dos princípios do TAM era que os atores não deveriam sobrepor-se uns aos outros ou deixar que a vaidade e o poder os vencessem. O Livro de cabeceira do artista dramático, disponível atualmente em espanhol pela editora Quertzal, Stanislávski diz que:

Todo compromisso é por si só enganoso já que consente as paixões invariáveis dominantes no indivíduo.

O poder da tentação se agudiza em meio à atmosfera de lisonja, vaidade e admiração que rodeiam o artista. Por outro lado, o bem-estar material do artista se encontra em relação direta com o êxito e este último, na dependência dos caprichos do público, que gosta de criar ídolos e destroná-los.

Aí está o porque de a vaidade e o cálculo material tão frequentemente obrigarem os artistas a abandonarem seus ideais estéticos. (STANISLÁVSKI, 1986, p. 84). [tradução nossa]

É evidente neste trecho outra vez a interligação existente no trabalho de Sulerjítski e Stanislávski no que se refere à estética teatral e à ética filosófica.

Não por acaso Smychliáev recordou sobre Sulerjítski que:

Também no estúdio ele deixou um ensinamento: o repertório teatral deve ser construído de maneira que em cada peça se reflita a natureza de cada alma humana, sempre chamando-a para uma vida melhor. E neste movimento em direção ao melhor está também o caminho da perfeição da personalidade do artista.

A criação é um ato de aperfeiçoamento. 
Assim o aspecto 'ético', como se expressava Leopold Antónovitch, relacionava-se intimamente com o 'estético'.

'Sem ética não há estética era o constante leitmotiv de suas conversações e da atuação prática. $\mathrm{Na}$ arte o importante não é apenas $o$ que (isto é, o conteúdo no sentido mais estreito desta palavra), mas também o como (isto é, a forma). A forma sem o conteúdo é uma flor estéril. O conteúdo sem a forma, não é uma obra de arte. E ambos são inseparáveis, um não pode existir sem o outro na verdadeira obra de arte. [Tradução nossa]

O interesse tanto pela questão ética quanto pela questão estética levou Leopold Sulerjítski a introduzir no Estúdio um livro onde os alunos poderiam se expressar tanto com relação às apresentações, quanto sobre questões éticas ou outras que desejassem: quer dizer, neste novo espaço todos teriam voz para algo muito maior do que criar um rotineiro protocolo. Através de anotações, censuras, desenhos, piadas ou epigramas, todos poderiam demonstrar seus mais profundos anseios e pensamentos, questionar regras ou falar sobre suas próprias necessidades.

Foi o que ocorreu com Leopold Sulerjítski certa vez. Transtornado por um caso de falta de respeito para com os empregados do Estúdio, o diretor em 8 de outubro de 1915 escreveu uma longa carta a seus alunos, a qual por seu caráter profundamente ético, merece ser aqui traduzida na íntegra:

Senhores estudantes,

chamarei sua mais séria atenção para as coisas que desonram o estúdio de vocês ou, se isto for forte demais, então ao menos para aquelas que não possibilitam ao estúdio permanecer tal como vocês desejariam que ele fosse.

Falo sobre a atitude de vocês com relação aos empregados. Não se deve aproveitar do trabalho destas pessoas sem prestar atenção em como elas vivem, em que condições, como dormem, como se vestem, como descansam, se tem lugar e tempo para almoçar, se não vivem no lodo, etc. $\mathrm{O}$ trabalho é muito árduo; vocês tomam delas o dia e a noite, mas dão apenas o ordenado e mais adiante cospem nelas completamente.

Eu compreendo que é difícil exigir que se tenha consideração humana por elas, pelo homem, por cada homem em particular, uma vez que nós já somos suficientemente desatentos com as pessoas mais próximas; mas, apesar de tudo, ser como aqueles que na Inglaterra são chamados de "espremedores de suor" é bastante vergonhoso.

Pois estamos nos aproveitando das admissões escravistas. Há muito que eu não via condições tão anti-higiênicas e abomináveis e semelhante desatenção para com o homem trabalhador. E isso num trabalho onde pessoas jovens estão reunidas para se dedicarem à arte, cujo objetivo é forçar as 
pessoas a serem atenciosas umas com as outras, cujo objetivo é abrandar o coração, enobrecer o caráter. Este aspecto é uma grande lacuna em suas vidas e é perigoso não para o trabalho, mas para vocês.

Autorizar devidamente o aumento de dois ou três rublos no ordenado é absolutamente impossível; significaria apenas que das pessoas que se aproveitam dos escravos, vocês são aquelas que não se aproveitam deles abaixo do preço estabelecido no mercado, só isso; mas o humano começa apenas a partir do momento em que, embora pouco e minimamente, a própria pessoa dá atenção à vida pessoal de cada um. Mesmo que minimamente.

Para isso é indispensável imaginar com clareza, ainda que uma vez, como se passa a vida de cada uma destas pessoas.

Eis, por exemplo, a função do foguista. De manhã ele deve rachar lenha para todos os fornos - os doze que nós temos no apartamento -, e para cada um deles são necessárias quinze achas (aproximadamente duzentas achas) ${ }^{74}$; ele precisa trazê-las todas e a distância do nosso galpão é tal que é como se ele contornasse todo o quarteirão, precisa subi-las até o terceiro andar, distribuí-las pelos fornos, depois avivar o fogo destes fornos, fechar todos eles, retirar a cinza, colocar os samovares, correr atrás da remessa, ficar na antessala e, após almoçar de pé porque não há onde se sentar, continuar então o serviço, andando o dia inteiro na pontinha dos pés por respeito - o que é muito cansativo -, e à noite, antes das dezenove horas, preparar o chá, distribuí-lo e recolher tudo. Em seguida, precisa se deitar sem jantar, num quartinho sufocante, onde já está posta uma cama na qual estão deitados juntos dois irmãos que levaram o mesmo tipo de dia, senão pior.

Isso não é bom. Lembrem-se de que estas pessoas não têm lar, que este quartinho sufocante e imundo é uma casa sem cuidados domésticos, sem conforto, zelo, e nem uma palavra de atenção e que, desta forma, neste trabalho não espiritualizado, barulhento e servil - pois é incompreensível - , passa-se inicialmente a adolescência, depois a juventude, a vida adulta e a velhice. Na poeira, no mormaço, no serviço e, o principal, sem a menor alusão a algo que se refira de um modo ou de outro ao lado espiritual do homem. A menos que eles vigiem por uma frestinha como vocês cantam e interpretam, como ontem no concerto experimental. E tudo isto em uma instituição que só se enche de arte refinada.

Prestem atenção vocês mesmos para que isso tudo seja mais humano. Não sejam passíveis de uma vergonha injustificada e, mesmo que só um pouquinho, reconheçam como vivem estas pessoas que carregam por vocês o trabalho braçal, e se tentarem algum dia incluir qualquer gotinha de prazer em suas vidas, acreditem que esta gotinha não desaparecerá. O trabalho físico não é de forma alguma uma coisa da qual precisemos fugir, ele pode dar grande alegria, mas o serviço, o servilismo, a

${ }^{74}$ O Primeiro Estúdio ocupava não um alojamento teatral especial, mas um grande apartamento, uma sala de estar que era transformada em sala de teatro. Nesta sala havia uma lareira, que assim serviu para $O$ grilo na lareira como atributo do espetáculo. (N. ed. russa). 
permanente servidão a outros e a absoluta carência do que deveria ser atenção e afeto, criam tamanha desolação e de tal modo oprimem e endurecem o homem, que ele perde completamente o interesse inclusive por si mesmo, se endurece e se extingue, e cria-se um escravo no lugar do homem que se perde; não é oportuno que vocês participem disso; comparados a eles vocês são demasiadamente ricos em fartura e alegrias espirituais. Que pelo menos, às vezes, pareça-lhe que também tem uma "casa". Que ao menos de quando em quando, ao deitarse após um dia de trabalho duro, ele sinta que alguém pensou nele, mesmo que um pouquinho, e adormeça sem a consciência de que o compraram, de que compraram o seu trabalho, e de que para vocês isso não fará nenhuma diferença mais adiante. Para que estas paredes, se não são muito cômodas, sejam para ele, apesar de tudo, quentes e agradáveis, para que atrás delas seja pelo menos um pouquinho mais caloroso do que é lá fora, na rua, onde tudo é guerra, onde precisam apenas de seus braços e pernas, onde querem dar-lhe o mínimo e dele extrair o máximo possível.

Não sou sentimental. E assim preciso de pouco: apenas que não procedam como os piores dos escravocratas. E cuidem de si mesmos, cada um de vocês transformando-se a si mesmo nesta esfera; a si mesmo, porque precisamente cada um se aproveita deles; e porque ninguém consegue fazer isso pelo outro. Se elegerem alguém para chefiá-lo, que este fale com ele em voz baixa, peça, informe-o sobre aquilo que é de seu interesse, e principalmente, lembre-se de que apenas cada um em pessoa pode ajudar nisso. Eu gostaria que cada empregado pudesse dizer 'nosso estúdio' tanto com amor, quanto com um sentimento caloroso. E, além do mais, precisamos refletir sobre isso de modo geral para que o estúdio seja mais caloroso e confortável a cada membro seu. Precisamos nos unir mais. Precisamos dar mais lugar ao trabalho dos outros. Hoje, por exemplo: por vontade própria, em um dia de trabalho, Tezavrovski ${ }^{75}$ juntou e organizou contra as janelas os quadros necessários para a sala de espetáculos. Ele precisou passar o dia trabalhando intensamente num ofício de carpinteiro. E por acaso não o fez com alegria? Se todas as paredes, se todo o estúdio estiver impregnado pelo próprio trabalho utilizado para o seu aperfeiçoamento, vocês verão como crescerá todo o estúdio, como ele terá valor e será estimado por todos e como cada um se sentirá ofendido com qualquer comportamento negligente e superficial. O refeitório, por exemplo, não chega na organização do estúdio. É muito difícil fazê-lo, isso está absolutamente correto, mas ele é completamente indispensável. Juntemo-nos em algum lugar e de passagem discutamos atentamente. Se o dinheiro não for suficiente para o início eu o darei, já tenho para isso, embora eu desejasse me esquivar. Mas ele é necessário. Não fiquem só agitando os braços e dizendo que isso é indispensável. Aí está a nossa força, que pareceria indispensável para chegar a ser possível e executado. Se o mais indispensável, isto é, o próprio estúdio, com sua organização, seus espetáculos, a trupe, o

\footnotetext{
${ }^{75}$ V. V. Tezavrovski - jovem ator do TAM e do Primeiro Estúdio (N. ed. russa)
} 
orçamento e suas relações, não só é possível como também existe e está prosperando, bem, por acaso isso não é um milagre? Como então é possível não ter fé naquelas pequenezas quando em comparação a isso? As pessoas não acham uma saída? Então, por que? Por que essa dúvida? Olhem para trás, três anos atrás, e vendo aquilo que vocês já fizeram neste tempo, envergonhem-se de sua pouca fé, borrem-na o mais rapidamente possível, observem melhor à sua volta, olhem um ao outro no rosto, sintam que vocês já são um grupo sério e não um grupo colado com saliva, mas com algo mais forte, sintam sua força mais depressa e para isso percebam com mais frequência um ao outro, martelem mais depressa o rebite nos laços do novo navio "Estúdio" e movam-se erguendo amistosamente a bandeira de "Fé, amor e esperança", olhando adiante atentamente, pois neste ano vocês devem fazer muitíssimo, como talvez, não tenham feito no decorrer destes três anos.

Cada um deve se lembrar que apenas aquele que disser para si mesmo "Eu sou um estudante de teatro!" poderá se tornar um estudante de teatro do Estúdio e que a partir deste momento este vai acreditar que justamente dele depende toda a existência do estúdio, de sua atenção e preocupação com cada aspecto da vida do estúdio, de sua condescendência, de sua prontidão para trabalhar e doar seu próprio tempo, seu trabalho, sua experiência e muito, muito, muito mais. Quanto mais você sacrifica, mais ganha.

Isto não é da crestomatia, mas da vida; olhem para a vida de todos os membros do estúdio e vocês verão que é assim. Lembrem-se apenas de que vocês devem o quanto antes sentir se fortemente unidos entre si e fortemente unidos com aquele que os criou: o Teatro de Arte.

O quanto antes; assim pressente meu coração. L.S.

[Tradução nossa]

Se Stanislávski já dizia em seu livro de cabeceira que o reconhecimento do teatro como arte verdadeira depende, antes de tudo, de os artistas se conscientizarem de sua missão (STANISLÁVSKI, 1986, p. 84), eis nesta carta um exemplo de apelo onde é possível enxergarmos a necessidade de uma nova consciência por parte dos artistas: a necessidade de respeito para com o trabalho do próximo.

Apelo, talvez, muito próximo ao que Lev Tolstói faz à sua nora Sófia N. Tolstáia em uma carta de 1902. Nesta carta, ao tratar da questão da educação, o escritor fala do quanto acredita que "as crianças devem estudar o menos possível” (TOLSTÓI, 2011, p. 213), uma vez que não é um problema tão grave crescerem sem saber uma ou outra questão. Mais grave é quando as crianças criam uma espécie de indigestão com relação aos estudos e se fartam dele de vez. 
Supondo que talvez sua leitora argumentasse contra sua noção, Lev Tolstói diz a seguir:

O argumento contrário, no entanto, com frequência é: se as crianças não estudarem, de que se ocuparão? De todos os tipos de tolices e patifarias com as crianças camponesas? Levando-se em conta nossos hábitos grã-finos de vida, tal objeção provém de um raciocínio lógico. Mas será necessário habituar as crianças a uma vida grã-fina, ou seja, de modo que elas saibam que todas as suas necessidades, sejam quais forem, serão satisfeitas sem nenhum esforço da parte delas? Por isso a primeira condição para uma boa educação é que a criança saiba que tudo aquilo de que ela precisa não cai pronto do céu, mas é o resultado do trabalho de outras pessoas. Compreender que tudo que a circunda resulta do trabalho alheio, do trabalho de gente desconhecida e que não necessariamente a ama está bem acima da compreensão da criança (Deus queira que ela entenda isso quando se tornar adulta), mas ela deve entender que o penico em que urina é esvaziado e lavado sem nenhum prazer por sua babá ou pela criada e que o mesmo ocorre com suas botinas e galochas, que ela encontra sempre lavadas e limpas, e que tudo isso não é feito por mágica nem por amor a ela, mas por razões que ela ignora, que ela pode e deve entender, e das quais deve se envergonhar. Se ela não sentir vergonha e continuar a se aproveitar disso, isso é indício da pior educação, que a marcará profundamente por toda a vida. Evitar isso, no entanto, é muito fácil e por essa razão eu the suplico, (para empregar um estilo mais poético) do meu leito de morte, que pratique isso com seus filhos. Deixe-os fazer com empenho, tudo o que precisarem fazer para si próprios: descartar as próprias fezes, pegar água do poço, lavar a louça, arrumar o quarto, limpar os sapatos e as roupas, arrumar a mesa e assim por diante, deixe-os fazer sozinhos. Acredite em mim, por mais insignificantes que tais tarefas possam parecer, elas são muito mais importantes para a felicidade de seus filhos do que o conhecimento da língua francesa, de história, e assim por diante. (...) Com este princípio, eliminamos duas questões de uma vez: ela permite que se estude menos, utilizando o tempo de maneira mais proveitosa e natural, e acostuma as crianças à simplicidade, ao trabalho e à autonomia. (...)

Acredite em mim, Sonia, sem essa condição não há educação moral nem cristã, nem consciência de que todos os homens são irmãos e iguais entre si. Uma criança é capaz de entender que um adulto, que seu pai - seja ele banqueiro, torneiro, artista ou feitor -, cujo trabalho alimenta a família, pode ser dispensado dessas tarefas caso estas o impeçam de dedicar todo o seu tempo à realização de seu trabalho. Mas como uma criança pequena, que ainda não tem habilidade para fazer nada, pode ser capaz de entender que outros façam para ela aquilo que the parece tão natural fazer sozinha?

A única explicação para essa questão é que as pessoas se dividem em duas classes - senhores e escravos; por mais que expliquemos à criança as palavras 'liberdade' e 'fraternidade', as 
pessoas e a maneira como elas vivem, desde que se levantam até a hora do jantar lhe provarão o contrário.

Além disso, nos ensinamentos dos mais velhos sobre moral, a criança perceberá, no fundo de sua alma, que todos os sermões são enganosos, e ela deixará de acreditar em seus próprios pais e em seus mestres, e até mesmo na necessidade de qualquer moral, seja qual for. (....) (Ibidem, p. 213-6).

Embora uma das cartas trate da educação de alunos jovens de uma escola teatral enquanto a outra considera aspectos da educação infantil, ambas têm como fio condutor unicamente o aperfeiçoamento moral do ser humano. A criança mal-educada de hoje poderá ser o adulto desatencioso de amanhã.

Em ambos os textos, com grande maestria os autores olham, não para si e nem somente para aquele a quem dirigem a carta, mas para um outro, fora desta esfera da correspondência ocorrida e que provavelmente leva uma vida muito mais sofrida do que eles. Tanto Lev Tolstói, quanto Leopold Sulerjítski sabem o que deve ser feito e recomendam-no, suplicam-no. Mas em momento algum impõem que seja feito. O que é significativo, visto que agindo assim exercem influência moral sobre seus interlocutores. ${ }^{76} \mathrm{E}$ ao mesmo tempo inserem em seus discursos a noção do dever, considerada uma das mais fundamentais para a ética. De acordo com o pesquisador Danilo Marcondes (2015, p. 9):

\begin{abstract}
A problemática da ética, portanto, em um sentido amplo, diz respeito à determinação do que é certo ou errado, bom ou mau, permitido ou proibido, de acordo com um conjunto de normas ou valores adotados historicamente por uma sociedade. Esta definição é importante porque o ser humano deve agir de acordo com tais valores para que sua ação possa ser considerada ética. Desta forma se introduz uma das noções mais fundamentais da ética: a do dever. Os seres humanos são livres. Em princípio podem agir como bem entenderem, dando vazão a seus instintos, impulsos e desejos; porém o dever restringe essa liberdade, fazendo com que seja limitada por normas que têm por base os valores éticos. O ser humano pode agir de diferentes maneiras, mas deve agir eticamente.
\end{abstract}

Era o que Leopold Sulerjítski desejava de seus alunos. Que agissem eticamente, mas sempre por escolha própria, entendendo e aceitando conscientemente as razões por

\footnotetext{
${ }^{76}$ De acordo com Aranha (1986,p.304): "a moral, ao mesmo tempo que é o conjunto de regras que determina como deve ser o comportamento dos indivíduos de um grupo, é também a livre e consciente aceitação das normas. Isso significa que um ato só é propriamente moral se passar pelo crivo da aceitação pessoal da norma. À exterioridade da moral contrapõe-se a necessidade da interioridade, da adesão mais íntima."
} 
ele apontadas. Por não dissociar o processo de aperfeiçoamento humano do profissional, aproveitava cada detalhe da vida no Estúdio para incutir princípios éticos em seus alunos. E elevar seu entendimento não apenas com relação à arte do ator, mas, sobretudo, com relação à vida do ser humano.

\subsubsection{De repente sou gaivota}

Como uma gaivota, vôo sobre o mar.

Vejo um barco. Pouso em sua bandeira.

"Fé, amor e esperança" Dizem.

Três palavras.

Um poema.

Sou eu que tenho asas

Mas eles é que cruzam o infinito. 


\section{CAPÍTULO 2 - LEOPOLD SULERJÍTSKI - HOMEM DE SEU TEMPO}

\subsection{Ainda a escuridão?}

Agora já vemos seu rosto.

Sabemos quem é este homem e o que veio fazer quando seu barco resolveu ancorar em nosso mundo (durante o período de 44 anos).

Por que, então, o palco ainda não se fez luz por inteiro?

Ouvem-se vozes. Mais diálogos?

Talvez seja o momento de entendermos também quem foi o homem por trás do diretor-Sulerjítski. Em que acreditava, contra o que lutava e, principalmente, o porquê de haverem três distintas figuras dividindo o palco com ele neste exato instante do espetáculo.

Se um destes com certeza é Tolstói e o outro é indubitavelmente Stanislávski....

Que as cortinas se abram definitivamente diante de nossos olhos, para que também se descubra quem é este terceiro!

\subsection{Mas afinal, quem é o terceiro?}

Chama-se Vsevolod Emilevitch Meyerhold (1874-1940) e creio eu que dispense apresentações muito detalhadas neste trabalho, uma vez que foi grande sua significação para o teatro do século XX e que o papel por ele desempenhado conta atualmente com excelentes trabalhos escritos em português por Arlete Cavaliere, Beatriz Picon-Vallin e Maria Thais Lima Santos ${ }^{77}$

A participação de Meyerhold no que diz respeito à vida e à obra de Leopold Sulerjítski é relativamente pequena e ocupará uma cena curta de nosso trabalho. O que não quer dizer de forma alguma que devemos desprezá-la ou considera-la banal. Muito pelo contrário, pois apesar de curta, esta inter-relação estabelecida foi significativa e ajuda a melhor compreendermos quem foi Leopold Sulerjítski.

\footnotetext{
${ }^{77}$ Estes trabalhos encontram-se devidamente indicados na bibliografia de nosso trabalho.
} 


\subsubsection{Na vida}

Em 20 de dezembro de 1916, Meyerhold escreve um necrológio para o jornal Bírjivie Védomosti. Neste artigo, começa por apresentar Leopold Sulerjítski justamente como uma figura multifacetada e digna de nota, embora pouco conhecida pelo público de sua época. Para Meyerhold, seria necessário escrever mais do que um necrológio para dar conta de todas as facetas desta personalidade que ele chama de extraordinária e que em sua opinião, apesar de extraordinária, ficou desconhecida por dois fatores: primeiramente pela falta de seu nome nos cartazes das peças; e em segundo lugar, pelo fato de jamais ter procurado fazer publicidade de si mesmo.

Um aspecto relevante deste artigo de Meyerhold é a sua descrição de um encontro com Lev Tolstói ocorrido em 1905. Diz ele

\footnotetext{
Eu vi com que alegria extraordinária se iluminou a face de Lev Nikoláievitch quando viu que Sulerjítski ultrapassava a soleira de sua casa em Iássnaia Poliana. Pelos quartos do silencioso casarão irromperam de Suler cantos da estepe e durante um dia inteiro houve na casa aquela vivacidade que Tolstói buscava tão apaixonadamente. E então me pareceu que o que Tolstói amava em Sulerjítski era não apenas o representante de suas ideias, mas, principalmente, a sua alma de vagabundo (MEYERHOLD, 1970, p. 578) [Tradução nossa]
}

É justamente a esta alma de vagabundo, que Meyerhold dá especial destaque no artigo, incluindo-a como o verdadeiro diferencial de Leopold Sulerjítski dentro de seu trabalho com o teatro: "Sulerjítski, que amava o mar, que amava a música e que, como Tostói, amava a canção cigana, poderia ir adiante no teatro? Vagabundo de nascença, ele deu à arte aquilo que um artista de alma burguesa jamais dá a ela.”. (Ibidem) [Tradução nossa]

Apesar de ambos não terem desenvolvido relações muito próximas no decorrer de suas vidas, ambos se respeitavam e Vsevolod Meyerhold reconhecia o papel crucial de Leopold Sulerjítski para o Primeiro Estúdio e para o TAM. Ao finalizar seu necrológio ele diz que "o Estúdio ligado ao Teatro de Arte, guiado eternamente pelo jovem Stanislávski deve vestir um luto profundo por ter perdido um rebelde enérgico como Sulerjítski, tolhido pela morte na noite de 17 para 18 de dezembro de 1916" (Ibidem, p.579) [Tradução nossa] 


\subsubsection{Na arte}

Em 1906, Meyerhold, que havia sido ator do TAM até 1902 e que se entregara à tarefa de desenvolver um Estúdio Teatral ao lado de Stanislávski em $1905^{78}$, é convidado para trabalhar como diretor ao lado da já famosa atriz Vera

Komissarjévskaia. É precisamente este trabalho de ambos o responsável por provocar "o surgimento de uma das grandes questões do teatro no século $\mathrm{XX}$ : a cisão entre o encenador e o ator" (SANTOS, 2009, p. 30)

Vera Komissarjévskaia acreditava no teatro simbolista como um teatro do ator em que o exterior estava submetido ao interior e supunha que fosse assim também para Meyerhold. Mas se para ela a princípio a maneira de olharem para o teatro convergia neste aspecto, o tempo se encarregou de demonstrar a existência de diferentes tendências e convicções entre ambos.

Meyerhold via no drama simbolista de Maeterlinck um pretexto para a criação de uma nova técnica, de um drama estático. Para ele, numa representação simbolista não deveria haver qualquer vínculo com a vida, sendo a ação substituída pela situação; a ação, vista "não como uma série de eventos externos, mas como um acontecimento da alma da personagem, materializando-se nas pausas, nos silêncios e, principalmente, nas formas e nos movimentos plásticos." (SANTOS, 2009, p.34)

No período em que faz parte da companhia de Komissarjévskaia, Meyerhold leva até o limite as concepções inicialmente formuladas no Teatro-Estúdio da Rua Povarskaia e põe-se agora a trabalhar visando uma nova abordagem do trabalho do ator. Através do

\footnotetext{
${ }^{78}$ Conhecido como Estúdio da Rua Povarskáia, foi a primeira tentativa de Konstantin Stanislávski de se dedicar à busca por novas formas artísticas e o descarte do realismo d'Alma. Para esta empresa, ele conta com a participação de Vsevolod Meyerhold, o qual também busca novas formas de atuação justamente na mesma época. Esta busca é descrita por Batchélis (2011, p.9) não como um capricho dos encenadores daquele tempo, mas como uma exigência da própria arte russa, numa época em que a sociedade do país se tornava cada vez mais complexa. De acordo com SANTOS (2009,p.23), experimentou-se neste Estúdio criado por Stanislávski e Meyerhold a 'estatuária plástica', " não como uma cópia das pinturas, mas a partir da imaginação criativa do diretor, que pretendia concentrar o ator - física e mentalmente - através das poses, do desenho do gesto e da ênfase do perfil do corpo." (2009, p.23) Ao aproximar a linguagem pictórica da expressão do ator, Meyerhold submetia completamente o temperamento do intérprete à forma exterior. Este fator, aliado à falta de talento dos intérpretes fez com que o ensaio geral de A morte de Tintagiles, de Maeterlinck, momento de revelação dos trabalhos que vinham sido realizados no Estúdio, fosse um fracasso e resultasse em seu encerramento Embora houvessem convergido inicialmente no fundamental, buscando no Teatro-Estúdio novas formas de concretizar as inovações propostas pelo drama simbolista, Stanislávski e Meyerhold agora partiam cada qual para seu caminho, cada um com as próprias convicções, sendo que enquanto o primeiro perseguia o absoluto teatral por meio da representação formal (do exterior para o interior), o segundo guiava suas buscas por meio da via da representação mimética (do interior para o exterior).
} 
princípio da estilização, submete o ator à imobilidade. $\mathrm{O}$ ator passa então a ser visto como um corpo estático, que ora revela um caráter pictórico, ora um caráter escultural, tornando-se "marionete" nas mãos do encenador.

Quando Leopold Sulerjítski trata das relações entre ator e diretor em uma apresentação realizada no museu Politécnico em 25 de outubro de $1909^{79}$, utiliza precisamente estes acontecimentos de 1906 a 1907 como pano de fundo para tudo aquilo que irá dizer.

De acordo com Sulerjítski, Meyerhold havia errado em suas convicções a partir do momento em que fizera do ator um ser desprovido de personalidade. A individualidade do ator era justamente aquilo que Leopold Sulerjítski mais desejava alcançar em seus trabalhos teatrais. Por isso ele acreditava que nem mesmo o mais simples de todos os atores conseguiria deixar de lado a sua própria criação para se tornar um fantoche nas mãos do diretor. Diz ele:

No campo da arte e da criação não se pode de jeito nenhum nem forçar e nem mandar nos sentimentos. Nenhum ator, mesmo o de menor talento, mudará sequer uma característica da personagem que ele mesmo criou durante todos os tormentos da criação, ainda que o próprio Stanislávski tenha lhe ordenado isso." (SULERJÍTSKI, 1970, p.317) [Tradução nossa]

Enquanto Meyerhold neste período de sua vida descartava a individualidade do ator como elemento central do fazer teatral, Leopold Sulerjítski insistia em seu ponto de vista ao dizer:

\footnotetext{
Uma vez que não há personalidade, não há nada; e não há nada para ser conduzido à harmonia; tudo se torna trivial e indiferente. Se toda uma orquestra se preencher de cornetas que sabem emanar apenas uma nota musical, então é pouco provável que até mesmo um contrapontista como Serguei Ivánovitch Taniéiev comece a escrever uma sinfonia para tal orquestra. Por outro lado, quanto mais vivas os matizes de cada instrumento isolado, quanto mais vasto e flexível o diapasão deles, tanto mais plena e mais forte harmonia é possível, e maior talento é preciso para este maestro e compositor. (SULERJITSKI, 1970, p.320) [Tradução nossa]
}

Sulerjítski acreditava ainda caber ao diretor entusiasmar e atrair a individualidade do ator, de forma a dar sentido ao seu trabalho criador. Somente uma tal relação seria capaz de educar verdadeiramente o ator, auxiliando-o em seu crescimento e

\footnotetext{
${ }^{79}$ A tradução completa desta apresentação encontra-se como anexo a este trabalho.
} 
desenvolvimento interior. No entanto, se o diretor não entusiasmasse e nem desse valor à dada individualidade, além de esta tornar-se fria e refratária, todo o trabalho de direção acabaria arruinado.

Por isso é que em sua apresentação, Sulerjítski faz um apelo à existência de boas relações entre ator e diretor, focando na relevância de o Teatro possuir bons diretores, os quais deverão auxiliar os atores no trabalho sobre si mesmo ${ }^{80}$ :

Todo o intenso trabalho de um diretor contemporâneo em relação ao ator consiste precisamente nisto: em ajudá-lo a encontrar-se a si mesmo, ajudá-lo, como dizem, a "revelar" sua personalidade até uma grande profundidade possível, ajudá-lo a separar em seu trabalho aquilo que de fato representa sua verdadeira individualidade, do geral, do teatral, do assim chamado "clichê", que apesar de ser próprio de cada um, sendo em cada ator diferente do que é nos demais, não tem nada em comum com a sua verdadeira individualidade.

(SULERJÍTSKI, 1970, p.319) [Tradução nossa]

Daí as severas críticas que faz a Meyerhold em sua apresentação, considerando-o o único diretor decadente dentre os diretores contemporâneos. Pois Meyerhold não apenas não realizava este tipo de trabalho com seus atores, como também - e principalmente - , havia se esquecido do ator completamente.

De acordo com a estudiosa russa Tatiana Batchélis (2011, p.34), era precisamente nisso que residiam as principais divergências entre Konstantin Stanislávski e Vsievolod Meyerhold até o ano de 1917. Enquanto Meyerhold via a filosofia geral do espetáculo como sendo o aspecto mais importante no teatro, Stanislávski corroborava para o que diz Sulerjítski em sua apresentação, vendo o essencial justamente na verdade pessoal dos sentimentos e na vida espiritual da individualidade. ${ }^{81}$

Com seus procedimentos de baixo-relevo frontal da mise-en-scène dos atores petrificados em poses ao longo de uma comprida parede, com sua estatuaridade e o "teatro imóvel" do simbolismo, Meyerhold matava justamente um dos princípios do teatro segundo a visão de Stanislávski e Sulerjítski. De acordo com Sulerjítski:

Aqui o talentoso e inteligente Vsévolod Emílevitch Meyerhold cometeu um erro. Esquecendo-se do ator, ele foi até o Teatro de Convenção, até a negação dos verdadeiros detalhes. Armado de

\footnotetext{
${ }^{80} \mathrm{O}$ trabalho sobre si mesmo é fortemente desenvolvido por Stnanivski desde o início de sua pesquisa com $\mathrm{o}$ ator, sendo alguns anos mais tare aperfeiçoado em seu Método das ações físicas.

${ }^{81}$ BATCHELIS, Tatiana. Stanislávski e Meyerhold, p.34.
} 
excelentes conhecimentos no domínio da representação teatral, sabendo penetrar profundamente nas ideias do autor e manobrálas perfeitamente, já que elas são abstratas, Vsévolod Emilevitch ,se afunda impotente nas profundas vivências dos homens vivos, perdendo-se entre a forma e o conteúdo. Em sua aspiração à criação de novas formas de teatro ele desprezou o ator e pagou um preço alto por isso. ${ }^{82}$ (SULERJÍTSKI, 1970, p.321) [Tradução nossa]

O problema, em sua opinião, não era o fato de Meyerhold estar voltado para um trabalho com o teatro de convenção, este teatro que buscava uma volta às origens. Pois o teatro de convenção não exigia um ator sem personalidade, esvaziado. Muito pelo contrário, era justamente o tipo de teatro no qual o ator precisaria ainda mais desta sua individualidade.

Somente um ator com forte individualidade e expressão interior, seria capaz de enfrentar um palco vazio e um fundo preto, sendo o único objeto de atenção do público. Somente um ator assim conseguiria preencher este espaço utilizando suas vivências.

Que concentração, que vivências profundas, que temperamento infinito é preciso para que sua atuação, além de transmitir os principais sentimentos da peça, faça também o público ver a floresta, o mar, escutar o seu barulho. E que incrível concentração e sinceridade é preciso para isto!

(SULERJÍTSKI, 1970, p.322) [Tradução nossa]

O problema, portanto, estava na maneira como Vsévolod Meyerhold olhava para o teatro de convenção, despersonalizando justamente, aquele que na visão de Leopold Sulerjítski não poderia jamais ser desprezado: o ator.

Mais tarde, em carta escrita ao dr. Herbert Graft em 11 de outubro de 1927, Stanislávski diferenciará claramente o seu teatro, deste em que o ator é só um material nas mãos do diretor:

Os princípios artísticos do Teatro de Arte de Moscou não têm como base o diretor encenador tipo Meyerhold ou Taírov, mas o diretor-pedagogo do ator. $\mathrm{O}$ teatro principalmente elabora a técnica interior da criação e foi nisso, depois de um longo trabalho, que ele conseguiu resultados importantes. Precisamos da encenação externa na medida da necessidade da criação interior dos atores.

\footnotetext{
${ }^{82}$ Quando fala em pagar um preço alto por isso, Sulerjítski se refere ao fato de o Estúdio da Rua Povarskáia ter sido fechado pouco depois de ter sido inaugurado, não tendo tido a chance de se desenvolver e alcançar a maturidade.
} 
Meyerhold e Taírov tem princípios diferentes. Enquanto no nosso teatro, para o ator, o diretor é o obstetra que recebe a nova criação dada à luz pelo ator, para meus companheiros de arte, Meyerhold e Taírov, o diretor está na cabeça de tudo, ele cria sozinho e o ator é apenas o material nas mãos do criador principal. A abordagem externa à arte, que era tão popular no nosso teatro, nós achamos ultrapassada. (STANISLÁVSKI, in:

VÁSSINA, E., LABAKI, A., 2015, p.66)

Esta apresentação realizada por Sulerjítski, em outubro de 1909, com as censuras e as convicções que ele apresenta, são uma forma de participação ativa em relação aos problemas de seu tempo. Aqui estamos frente a um homem que se questiona, indaga, busca por respostas e ao mesmo tempo tem claras e fortes convicções sobre a importância da arte teatral, do espaço que ela ocupa na sociedade e, sobretudo, do espaço que ele mesmo ocupa na esfera da arte, tomando para si a responsabilidade de abrir os olhos dos demais para elementos que não podem ser deixados de lado.

A partir disso, as noções que apresenta ao longo de sua fala já prenunciam a forma como ele irá encarar o trabalho no Estúdio. Pois desde esta época ele já se apega às vivências do ator como fator central para a verdadeira arte e acredita que:

\footnotetext{
Somente através do ator, do grande ator, através da escola da imersão e da vivência sincera e através do desenvolvimento da individualidade é possível passar para um espetáculo mais primitivo encenado com um fundo preto na superfície. É preciso passar com cautela, observando cuidadosamente para que o grau da convenção do espetáculo não esteja à frente do desenvolvimento do ator e por isso mesmo não o obrigue a forçar à sua criação, o que logo e inevitavelmente será refletido na sua sinceridade da maneira mais lastimável.(SULERJÍTSKI, 1970, p.322-3) [Tradução nossa]
}

\subsection{Na trilha de um mestre}

A aproximação existente entre Lev Tolstói e Leopold Sulerjítski é por mais de uma vez apontada por seus contemporâneos.

Sobre esta questão diz Evguêni Vakthângov (1970, p.577): 
"A Lev Sulerjítski de Lev Tolstói” Tolstói chamava Sulerjítski de "Levuchka" Lev e Levushka.

Em minha memória eles são inseparáveis. [Tradução nossa]

A proximidade de que fala Vakthângov tem como ponto de partida a admiração que Leopold Sulerjítski tinha por Lev Tolstói desde a infância e a juventude. Elena Poliakova conta como desde criança, quando ele ainda brincava sob o banco de carpinteiro que havia em sua casa, Sulerjítski ouvia os adultos lerem em voz alta obras de Tolstói como Os cossacos, Guerra e paz e a trilogia Infância-juventude. Sem contar o fato de que até hoje“" as crianças da Rússia, aprendem a ler e escrever pelas edições tolstoianas de 'Abecedários para crianças'. (POLIAKOVA, 2006) [Tradução nossa] e não foi diferente com Leopold Sulerjítski.

Aos 17 anos de idade, ele não apenas lia as grandes obras literárias de Lev Tolstói mas também seus artigos elaborados a partir da década de 80, quando o escritor revê muitos de seus conceitos, passa a ser considerado a consciência moral do povo russo e põe-se a escrever sobre toda a sorte de questões humanas: o aperfeiçoamento moral de si mesmo (tema caro a Tolstói desde a juventude ${ }^{83}$ ), a não resistência ao mal pela força, a verdadeira religião, o amor como a única coisa que importa ${ }^{84}$, a busca pela verdade, a benevolência, o vegetarianismo, o governo, o perdão, a arte, a educação e a revolta diante das diferenças sociais.

Lev Tolstói tinha a clara noção de fazer parte de um grupo de privilegiados e via como as classes ricas arruinavam os operários, obrigando-os a um trabalho rude, enquanto elas mesmas desfrutavam do luxo e do lazer. $\mathrm{O}$ fato de em sua opinião as classes sociais mais elevadas oferecerem aos operários apenas uma falsa religião, uma

\footnotetext{
${ }^{83}$ Ver: ERASSO, Natalia Cristina Quintero. Os diários de juventude de Lev Tolstói. Tradução e questões sobre o gênero de diário. Dissertação de mestrado, orientador: Noé Silva. São Paulo, 2011.

${ }^{84}$ Ver: TOLSTÓI, L.N. “Apelo ao clero” (1902) In:TOLSTÓI, L. N. Os últimos dias 2011. pp.217-242 ${ }^{80}$ A alta consciência dos problemas coletivos, o sentimento de culpa em relação aos sofredores e esta sede de justiça que aumentava cada vez mais - fatores estes sem os quais não podemos sequer conceber a existência de sua obra (SCHNAIDERMAN, 1983, p.76) -, fizeram com que Lev Tolstói desse um novo rumo a seus escritos, gerando uma grande reviravolta na carreira literária. De acordo com o escritor americano Jay Parini: "Com uma determinação única, Tolstói lançou-se a esses estudos religiosos e filosóficos, escrevendo inúmeras cartas sobre temas religiosos ou sociais para amigos e seguidores, alguns deles autodenominados 'tosltoístas', que o rodeavam ou o apoiavam à distância. Tolstói se tornou um profeta, apresentando uma visão do cristianismo que desvencilhava Jesus de seu status sobrenatural e focava em sua visão social. (PARINI, 2011, p.9) Tais escritos religiosos e filosóficos são o ponto de partida para a criação de um movimento ético e religioso surgido na Rússia durante a década de 1880 e mais tarde mundialmente conhecido sob o nome de Tolstoísmo.
} 
falsa poesia e uma falsa ciência fazia com que Lev Tolstói censurasse quem estava no poder e se dedicasse cada vez mais a pregar o amor entre os homens.

A questão das diferenças sociais incomodava também Leopold Sulerjítski. Ele, que não concordava com a disposição geral das classes, as injustiças e um mundo onde há servos e senhores, foi para o campo em 1889 e, sem jamais se envergonhar de sua visão, trabalhou ao lado dos camponeses, isto é, dos servos. Aprendeu a lavrar, ceifar, transportar esterco, cultivar hortaliças e tomar conta de currais tão bem quanto qualquer mujique, crendo sempre que as atividades exercidas no campo integravam a mais importante entre todas as profissões existentes no mundo. Não demorou a se tornar um trabalhador respeitado, um igual que não se achava superior aos demais e nem tinha "noção da exclusividade de sua situação, da penosa sensação de distância existente entre ele e os camponeses, o que quase sempre era do feitio dos intelectuais daquela época, desde os populistas até os tolstoistas” (POLIAKOVA, 1970, p.25) [tradução nossa]

Esta sua disposição para olhar a todos como iguais, teve seu reflexo mais tarde dentro do trabalho realizado no Primeiro Estúdio do TAM. Mikhail Tchekhov (1970, p.606) lembra como:

Às vezes Suler pegava uma vassoura e começava a varrer a sala onde se encontrava a maior parte dos estudantes. Isso significava que ele não se sentia bem como um senhor, que cada trabalho era digno de respeito e que se nós de fato amávamos o Estúdio, então não nos incomodaríamos em varrer o chão. (grifo nosso) [Tradução nossa]

Mas não era apenas a indignação diante das diferenças de classe que os unia. $O$ que os ligava, antes de tudo, era precisamente o que Elena Poliakova descreve como "o princípio humano salutar, a 'veia camponesa' sempre próxima de Tolstói, aquela alegria de viver, a transparência da alma, que era cativante em Sulerjítski e muito forte em Tolstói." (POLIAKOVA, 1970) [Tradução nossa]

Esta alegria de viver era particularmente forte em Leopold Sulerjítski. Vsevolod Meyerhold recordou-a em seu necrológio, como vimos. Olga Sulerjítskaia apontou-a também em suas recordações. Além de recordar como o marido enxergava o verdadeiramente valioso e característico que o povo trazia consigo, como era capaz de cantar canções judias como um verdadeiro judeu, polonesas como um verdadeiro polonês e ucranianas como um nascido ucraniano, Olga Sulerjítskaia lembrou-se de como ele tratava pobres e ricos igualmente e como "se aproximava das pessoas com um dom 
valioso: a alegria e o riso" (SULERJÍTSKAIA, 1970, p.514) Tatiana Tolstáia ${ }^{85}$, que havia estudado com Sulerjítski na Escola de Pintura, Arquitetura e Escultura de Moscou a partir de 1890, escreveu a este respeito em um texto, posteriormente lido na solenidade em memória de Leopold Sulerjítski, realizada no Primeiro Estúdio em 25 de janeiro de 1917:

\begin{abstract}
A vida deve ser maravilhosa.
As pessoas devem ser felizes.

E para a realização destes dois objetivos não convém desprezar nenhum ato, nem mesmo o mais miúdo e insignificante.

Se é possível dar alegria às pessoas por meio de um conto divertido ou uma anedota engraçada, então um viva ao conto alegre e à anedota engraçada!

Se é possível enfeitar a vida das pessoas com um quadro, com uma apresentação, com uma canção e para isso é preciso trabalho, então é preciso oferecê-lo com vontade e alegria. Se para a felicidade das pessoas for necessário sofrimento, é preciso ir até ele com ânimo, confiança e alegria.

Eis em suma a "profession de foi" de meu companheiro da Escola de pintura e escultura que há pouco se foi desta vida: L. A. Sulerjítski.

Não sei como ele mesmo avaliaria sua concepção de mundo interna. Talvez de um modo diferente do que estou fazendo. Talvez ele vivesse inconscientemente este amor à vida e a cada beleza sua que o levava a trabalhar contente e sofrer com alegria. Mas cada um que conhecia Sulerjítski não apenas sentia esta sua característica como também se contagiava com ela. (TOLSTÁIA, 1970, p.520)
\end{abstract}

Foi precisamente Tatiana Tolstáia quem apresentou Leopold Sulerjítski a Lev Tolstói. Já há algum tempo ela buscava jovens artistas para ajudarem seu pai a ilustrar os livros que ele vinha organizando com a intenção de publicar algo bom e barato para o povo. Mas ainda que tivesse apresentado vários colegas seus ao pai, apenas Sulerjítski permaneceu por longo tempo entre a família, fazendo visitas cada vez mais frequentes, nas quais "Ele se deleitava com as leituras das obras filosófico-religiosas do pai, escutava suas conversas com numerosos visitantes e logo se tornou muito próximo como homem pelas crenças e opiniões" (TOLSTAIA, 1970, p.622)

Ao chegar em Iássnaia Poliana, Leopold Sulerjítski modificou a rotina da família. Era sempre alegre e espirituoso, considerado um ótimo contador de histórias. Suas anedotas engraçadas inundavam de riso e alegria a casa durante as refeições; suas imitações de

\footnotetext{
${ }^{85}$ Uma das filhas de Lev Tolstói.
} 
pessoas, animais, pássaros e até mesmo objetos eram apreciadas por todos. As canções ucranianas, georgianas e judaicas - , eram belas e delicadas. Em suma, os familiares de Lev Tolstói conservaram Sulerjítski em sua memória como o "favorito geral”: um homem que nunca aborrecia e era sempre capaz de contagiar a todos por seu entusiasmo e alegria.

Nesta sua nova rotina, coube a Sulerjítski reescrever os manuscritos de Lev Tolstói, carregá-los para provas tipográficas e imprimi-los no mimeógrafo. Mas apesar deste seu novo trabalho como copista tomar-lhe toda a tarde, não largou as atividades do campo e a convivência com os mujiques e aproveitava as noites e o verão para ler as obras de Tolstói em voz alta aos camponeses.

Sulerjítski divulgava as obras de Tolstói, partilhando de seus pontos de vista na sociedade, na família e no trabalho e foi por muitos considerado tolstoista fervoroso. Mas de acordo com Elena Poliakova, é preciso tomar cuidado ao chama-lo desta maneira, uma vez que Lev Tolstói e Leopold Sulerjítski também divergiam em certos pontos ${ }^{86}$ e, mais importante do que isso, o diretor teatral não era pregador fanático dos ensinamentos de Tolstói e nem o olhava como a um deus.

Leopold Sulerjítski era um homem de ação. Sua natureza inquieta e questionadora o impedia de seguir qualquer homem cegamente. Em 1911, quando Górki se posiciona claramente contra as encenações das peças de Dostoievski, considerando-as nocivas para a sociedade, Sulerjítski defende o direito de o teatro encená-las. O que leva Górki posteriormente a escrever numa carta: "Súler é volúvel. Você nunca sabe o que ele vai

\footnotetext{
${ }^{86}$ Um bom exemplo é o caso relatado por Górki no "Capítulo III" de Leão Tolstói,. Aqui, vemos não só a descrição da admiração que Lev Tolstói nutria por Leopold Sulerjtiski, como também a divergência de opiniões de ambos em certo sentido. Nas palavras de Górki: "Ele trata Sulerjítski com uma ternura feminina. Gosta de Tchekhov como um pai, neste amor sente-se o orgulho de um criador, porém Suler desperta nele justamente ternura., um interesse e admiração permanentes, que parecem jamais cansar o feiticeiro. É possível que neste sentimento haja algo de ridículo, como o amor de uma solteirona pelo papagaio, pelo cachorrinho ou pelo gato. Suler é não sei que passaro deslumbrante e livre, de terras desconhecidas. Uma centena de homens como ele poderia mudar a face e o espírito de uma cidade de provincia. Eles destruiriam essa face e encheriam o espírito com uma paixão pela desordem violenta e talentosa. (...). Mas uma vez ele irritou-se profundamente com Súler; Leopold tendia para o anarquismo, discorria frequente e calorosamente sobre a liberdade individual e Lev Nikolaevitch, nessas ocasiões, sempre caçoava dele. Eu me recordo, Sulerjítski tirou uma brochura magra do príncipe Kropótkin e inflamou-se com ela, e o dia todo falou a todos filosofando demolidor. - Ah, Liovuchka, pare com isso, já aborreceu! - disse com enfado Lev Nikoláievitch. - Repete como um papagaio sempre a mesma palabra liberdade, liberdade, mas onde, em que consiste o sentido dela? Se você alcança a liberdade no seu sentido, como imagina que será? No sentido filosófico é um vazio sem fundo e na vida prática você acabará sendo um mendigo, um preguiçoso. O que ligará você que é livre a seu modo, com a vida, com os homens? (...) Cristo era livre, Buda também, e ambos tomaram para si os pecados do mundo e, voluntariamente foram para o cativeiro da vida terrena. E ninguém foi além disso, ninguém. E você, e nós, como somos? Todos nós procuramos liberdade das obrigações para com o próximo, ainda que justamente o sentimento destas obrigações seja o que nos faz seres humanos, se não existe este sentimento vivemos como feras..." (GÓRKI, 1983, p.14-16)
} 
fazer amanhã: jogar uma bomba ou cantar num coro" (in: POLIAKOVA, 2006, p.191) [Tradução nossa]

O mesmo no caso de Tolstói, que além de não ser visto como um deus, era questionado por Leopold Sulerjítski. Górki conta como certa vez Tolstói defendia os dukhobors como uma comunidade religiosa, quando foi contrariado: " “- E apesar de tudo o senhor não está certo disso que está defendendo', disse Súler, de repente, sorrindo. Lev Nikolaevitch lançou-lhe um olhar penetrante e, caindo na risada, ameaçou com o dedo, mas não disse nenhuma palavra." [Tradução nossa]

Leopold Sulerjítski tinha suas próprias convicções e o fato de ele não ser um tolstoísta como os outros todos ${ }^{87}$ é por mais de uma vez mencionado nas recordações de seus contemporâneos. Tatiana Tolstáia (1970, p.522) observa como ao contrário dos tolstoistas em geral, "Súler, caindo sob a influência de Tolstói, não perdeu a sua originalidade. Apesar do pensamento profundo, que Súler trabalhava continuamente em sua cabeça, ele permaneceu o galhofeiro alegre e o artista delicado que era antes." [Tradução nossa] O mesmo, embora com outras palavras, é lembrado por Mikhail Tchekhov (1970,p.609), em seu relato:

Chamavam Sulerjítski de tolstoista, mas se fosse assim, então ele era um tipo singular de tolstoista. Não havia nele nem sinal de fanatismo ou de sectarismo.

Tudo o que ele fazia de bem e de bom partia dele mesmo, era de seu feitio e as ideias de Tolstói não sobrepunham nele uma marca externa. [Tradução nossa],

O próprio Lev Tolstói punha em dúvida a questão de Leopold Sulerjítski ser um tolstoista no sentido usual desta palavra: "Bem, que tolstoista?”, disse Tolstói certa vez, “Ele simplesmente é como 'Os três mosqueteiros'; não um deles, mas os três!” Disse isso, conforme relata Górki, “com total fé em suas próprias palavras, esboçando o mais claramente possível a individualidade de Súler, com seu amor à ação, ao trabalho, à inclinação para a aventura quixotesca e a paixão romântica por tudo o que é belo." (GÓRKI, 1970,p.531) [Tradução nossa]

\footnotetext{
87 Apesar de ser estimado e respeitado por homens como V. Tchertkov e I. Gorbúnov-Possádov, considerados "pilares" do tolstoismo, Leopold Sulerjítski não era íntimo nem deles e nem de qualquer outro tolstoista. A sua "não passividade" era o que mais os distinguia.
} 
Mas que ele não tenha sido um fanático como os demais não implica na negação da proximidade de Sulerjítski e Lev Tolstói, seus ideais e maneira de olhar para o mundo. Conforme diz Elena Poliakova:

Então quer dizer que ele não é tolstoista? - Claro! - E ao mesmo tempo seria profundamente errôneo negar a gigantesca influência de Lev Tolstói sobre Suler, sobre toda a sua vida e visão de mundo. Sulerjítski sempre amou Tolstói - o homem e o artista. (...) A Sulerjítski era cara a convicção de Tolstói na necessidade do próprio aperfeiçoamento, a confiança de que cada homem deve fazer de tudo para se tornar melhor, levar às pessoas o auxílio e o bem. Como Tolstói, ele negava o regime estatal da época, baseado na violência e na injustiça. Como Tolstói, ele odiava a burguesia, sua mediocridade jactanciosa, como Tolstói, negava a igreja, seu ritual, e aspirava seguir o ensinamento de Cristo em sua "pureza" e os evangélicos preceitos de amor fraternal para com o próximo. (POLIAKOVA, 1970 p. 30) [tradução nossa]

Em 1895, Leopold Sulerjítski é convocado a servir no exército e por influência das ideias de Lev Tolstói passa a acreditar de todo o coração que a recusa é necessária, já que as guerras só deixarão de existir a partir do dia em que os homens se recusarem a lutar e servir ao Estado. ${ }^{88}$ Por conta desta recusa Leopold Sulerjítski foi preso no mesmo ano, tendo recebido visitas de Lev Tolstói e seus familiares.

Sobre uma das visitas de Lev Tolstói, o ator Evguéni Vakhtângov (1970, p.560) conta a seguinte anedota:

Sulerjítski esteve na prisão por sua recusa ao serviço militar. Tolstói visitou-o. Ficaram e silêncio um de frente para o outro, separados pelas grades.

\footnotetext{
${ }^{88}$ Cinco anos depois Lev Tolstói virá a escrever algo muito semelhante em Patriotismo e governo (1900), no qual critica ferrenhamente a noção que usualmente se tem de patriotismo. Para o escritor, o que está por trás do patriotismo é, não a ideia de amor exclusivo pelo povo ou a coragem de sacrificar a própria vida, mas uma fraude criada por governos criados para praticarem a violência com o próprio povo. Diz ele que: "Só o que desejamos é não fazer aos outros o que não queremos que nos façam. A guerra é consequência inevitável da existência de pessoas armadas. O país que mantém um grande exército permanente, cedo ou tarde, vai lutar. O homem que se vangloria da própria força em uma queda de braço em algum momento vai encontrar outro homem, que se considera o melhor lutador, e eles vão lutar. (...) Não que o povo queira a guerra, mas a classe superior insufla neles o ódio mútuo e faz com que as pessoas pensem que devem entrar em guerra para se defender. Pessoas que gostariam de seguir o ensinamento de Cristo são sobrecarregadas com impostos, são ultrajadas, enganadas e obrigadas a participar das guerras. Cristo ensinou a humildade, a docilidade, o perdão das ofensas e nos mostrou que matar é ruim. As escrituras ensinam as pessoas a não cometer perjúrio, mas 'a classe superior' nos obriga a jurar falsamente pelas Escrituras, em que não acredita.” (TOLSTÓI, 2011, p.176)
} 
Tolstói tranquilamente olhava de si para Sulerjítski. Sulerjítski, inclinando um pouquinho a cabeça, docilmente dando uma olhada em Tolstói, esperava.

- O senhor está bebendo?

- Não.

Silêncio.

- Fumando?

- Não.

Silêncio.

$-\mathrm{E}$ as mulheres?

- Não.

Tolstói carinhosamente apertou os olhos. Guardou silêncio.

Despediu-se igualmente em silêncio.

Aí está toda a conversa.

Por acaso não é assustador?

Não mate, não roube, não cometa adultérios. [Tradução nossa]

Quando Tatiana Tolstáia foi visita-lo, ficou impressionada com a maneira como Leopold Sulerjítski era capaz de manter sua alegria mesmo durante um sofrimento deste tipo. Ele sabia sofrer com alegria, sem esmorecer. Apesar das paredes e daquele ambiente assustador, "Ele estava alegre e jovial como sempre e dentro de dois minutos nós tagarelávamos com liberdade, como se nos encontrássemos em nossa querida Escola antiga ou em casa ${ }^{89} "$. (TOLSTÁIA, 1970, p.523) [Tradução nossa] Ainda assim, bastou falarem de seu pai que o havia visitado e implorado para que ele servisse ao exército para Sulerjítski se entristecer. Afinal, embora fosse contra seus princípios, ele iria cumprir o pedido de seu pai ${ }^{90}$

E cumpriu. Optando por servir ao exército. Mas como afirma Elena Poliakova, o próprio Lev Tolstói viu que não cabia a Sulerjítski tomar aqui o papel de mártir e compreendeu a decisão de Sulerjítski servir ao exército a pedido do pai. Assim, escreveu-lhe a seguinte carta entre 15 (27) de janeiro e 18 de fevereiro ( 1 de março) de 1896:

Caro Leopold Antônovitch,

Sofri com o senhor de todo coração ao ler sua última carta. Não se aflija, caro amigo. A questão não é o que o senhor fez, mas aquilo que o senhor tem na alma. O importante é este labor que se realiza na alma aproximando-o de Deus; e eu estou

\footnotetext{
${ }^{89}$ Refere-se aqui à propriedade de Moscou de Lev Tolstói.

${ }^{90}$ Sobre isso, Tatiana Tolstáia escreve: "Todo homem honrado que tenha sido obrigado a se submeter ao desejo de pessoas próximas em nome do amor e com isso renunciar à exigência de sua consciência consegue compreender como ele sofria ao aceitar este compromisso. Ele nos escreveu sobre isso." [tradução nossa] (TOLSTÁIA, 1970, p.523)
} 
convencido de que tudo isso que o senhor tem passado não o afastou, mas o aproximou dele. Uma conduta e esta situação na qual se coloca um homem por causa da conduta perfeita não possui por si só nenhum sentido. Cada conduta e a situação na qual o homem se coloca em consequência dela tem sentido apenas pela luta que provém da alma, pela força da tentação contra a qual se deu a luta, e o senhor teve uma luta terrivelmente difícil, na qual elegeu aquilo que deveria eleger. Não falo por brincadeira, mas com sinceridade, que em seu lugar eu com certeza teria agido tal como o senhor, pois me parece que é exatamente assim que eu deveria agir. Pois tudo o que o senhor fez, renunciando ao serviço militar, o senhor fez para não violar a lei do amor, mas o que viola mais o amor: tornar-se soldado, ou permanecer frio diante dos sofrimentos de um velho ? $^{91}$

Acontecem tais dilemas terríveis, e apenas a nossa consciência e Deus sabem se fizemos e estamos fazendo isso que fazemos para nós mesmos, para a nossa própria personalidade, ou para Deus. Tais situações, se são eleitas com certeza para Deus, acontecem inclusive vantajosamente: nós decaímos na opinião de pessoas (não das pessoas próximas, dos cristãos, mas da massa) e com isso apoiamo-nos mais solidamente em Deus. ${ }^{92}$

Não se entristeça querido amigo, mas alegre-se com esta prova que Deus the enviou. Ele nos envia provas de acordo com as forças de cada um. E por isso empenhe-se em corresponder à expectativa que ele tem no senhor. Não se desespere; não se desvie deste caminho pelo qual está indo, só porque este é um caminho estreito; concentre-se cada vez mais no desejo de conhecer a vontade dele e cumpra-a, não prestando atenção na própria situação, e principalmente, não prestando atenção naquilo que pensam as pessoas. Seja apenas humilde, sincero e afetuoso, e como que não parecerá complicada esta situação na qual o senhor se encontra: ela própria se desembaraçará. A situação é mais difícil quando a balança oscila e você não sabe qual prato pesa mais - o senhor já vivenciou isso. Continue assim, a viver amavelmente, tal como o senhor vivia com os que estão ao seu redor - humildemente, sinceramente - e tudo ficará bem.

\section{Lev Tolstói}

Amo-o incomparavelmente muito mais agora - depois do sofrimento que o senhor suportou - do que amava antes. ${ }^{93}$ [Tradução nossa]

91 O velho - Anton Matvéevitch Sulerjítski, que estava vindo de Kiev para encontrar o filho e que estava implorando a ele para concordar em servir ao exército. (N. ed. Rus.)

93 A firmeza e a renúncia de Sulerjítski ao serviço militar produziram grande impressão em L. N. Tolstói. Em 30 de novembro de 1895 ele escreveu a E. I. Popov: "Uma pena o senhor não ter visitado agora o sofrido Sulerjítski. Estive com ele duas vezes e me surpreendi com sua simplicidade, calma e benevolência. Ele tem uma revolução interior verdadeira e é bom por toda a parte." É interessante também a carta de L. Tolstói para A. A. Shkarvan, um médico austríaco que também renunciou ao serviço militar e que publicou o livro "Minha recusa ao serviço militar. Anotações de um médico de guerra." : "Suas anotações ainda me tocaram particularmente, porque agora em Moscou encontra-se no hospital militar, na seção dos doentes mentais, nosso jovem amigo Sulerjítski, ex-artista que, tal como o senhor, renunciou ao serviço militar. É admirável que a posição das autoridades com relação a ele e dele 
Nesta carta fica evidente o quanto Lev Tolstói compreende a busca de Leopold Sulerjítski por não ferir as leis do amor. Aliás, o que o escritor mais admirava em Sulerjítski era justamente o amor que ele nutria pelos demais. Em uma de suas conversas com Anton Tchekhov, Tolstói disse certa vez: “Aí está Súler: ele possui de fato uma valiosa capacidade de amar as pessoas desinteressadamente. Por isso ele é genial. Saber amar significa saber tudo.” [Tradução nossa]

Quando ocorre na Rússia o famoso caso da transferência dos dukhobors para o Canadá - questão que agitava fortemente a Rússia desde 1895 - , Sulerjítski tem a oportunidade de vivenciar todo este seu amor desinteressado.

Em 1895 os dukhobors desafiaram o Estado, recusando-se ao alistamento militar e à pratica de quaisquer atos violentos. Como consequência disso:

\footnotetext{
As autoridades enviaram soldados cossacos para sufocar o que foi entendido como uma rebelião. Os cavaleiros cossacos cercaram as comunidades dos dulhobors e os espancaram durante horas. Com seus compridos chicotes feitos de largas tiras de couro. As terras dos dukhobors foram confiscadas, suas casas, saqueadas, cerca de 7 mil pessoas foram banidas para aldeias remotas e seus líderes foram presos. (FIGUEIREDO, 2010)
}

Lev Tolstói que já os conhecia, mobilizou-se, escreveu manifestos, e por meio de seu discípulo Tchertkóv, conseguiu que fossem transferidos para uma área despovoada do Canadá, único país a oferecer-lhes abrigo. Teve então de levantar fundos para a viagem, escreveu cartas, pediu doações e, por fim, não sendo isto suficiente, publicou Ressurreição em 1899, abdicando dos direitos autorais em favor da empreitada que salvaria a vida dos dukhobors.

Diante destes episódios, em 4 (16) de julho de 1898 Leopold Sulerjítski escreve a Lev Tolstói:

Caro Lev Nikoláievitch, soube que os dukhobors vão se mudar e que logo virá de Batum o primeiro navio. (....) Ficaria feliz se o senhor me ajudasse a ficar por lá (no Cáucaso) entre eles e acompanha-los até o navio de destino, se aí for necessário um homem. Me parece que lá eu seria de certa utilidade, mas não sei

com relação às autoridades seja quase a mesma tanto na Rússia quanto na Áustria. Ele escreveu suas próprias anotações na época de sua prisão e eu pedirei a meus amigos um exemplar e enviarei ao senhor. Surpreendentemente, apesar da diferença na natureza da situação, há unidade no estado interior: há movimentos morais." (N. ed. Rus.) 
sobre as circunstâncias e gostaria de aconselhar-me com o senhor. (...) Falo inglês, (ainda que mal), conheço o mar e a vida portuária e os preços dos alimentos, e o principal, sinto que minha consciência e todo o meu ser exigem de mim que esteja com eles e os ajude no que de mim precisarem. (SULERJÍTSKI, 1970) [Tradução nossa]

A estas linhas, Lev Tolstói responde em 13 (25) de julho de 1898:

Ficaria muito contente se o senhor se juntasse aos dukhobors, Penso que o senhor lhes seria útil. Escrevi-lhes sobre o senhor. Se responderem que precisam de um homem assim, então será preciso escrever uma carta a Golítsyn, a qual o senhor deverá entregar-lhe, para que ele lhe dê a permissão de estar com eles.[Tradução nossa]

Posteriormente Leopold Sulerjítski consegue a autorização e parte para a América, onde irá permanecer com os dukhobors por dois anos antes de voltar para a Rússia sem um vintém sequer. Mas sabendo que fez o que deveria, pois muitos anos depois, Sulerjítski dirá em meio a uma conversa que: "No que se refere a minha vida, então apenas uma vez me senti absolutamente satisfeito em minha própria ocupação. Isso foi quando conduzi os migrantes para o Canadá. Isso sim! Isso foi verdadeiro!” (in:

BULGÁKOV, V.) [Tradução nossa]

Sim. Foi verdadeiro. E reconhecido. No livro de Poliakova encontra-se uma carta escrita por Potápov, um dos guias dos dukhobors, que nesta época se encontrava no Canadá. Ele escreve a Sulerjítski - nesta época na Rússia - solicitando auxílio na transferência de Fiódor Semiónovitch Aríschenkov para o Canadá, pois este se encontra sozinho, doente e longe de seus pais. Antes de finalizar a carta ele diz:

...Querido Lev Antónovitch! Nós sabemos que Deus o criou
especialmente para tais trabalhos e nós sabemos, que você é o
único dos nossos amigos que pode fazer isso.
É claro que você pode dizer: "Eu não sou um pássaro, não posso
levá-lo nas asas a uma longa distância tal como está a Sibéria é
difícil prestar ajuda, mas apesar de tudo nós acreditamos que
você pegará para si o trabalho e fará o que for possível.
...[Tradução nossa]

Toda a correspondência de Leopold Sulerjítski e Lev Tolstói trocada antes e durante a transferência dos dukhobors ao Canadá conserva-se atualmente no Museu de Lev Tolstói em Moscou. E desde a primeira carta quando Sulerjítski pede que Lev Tolstói aceite sua ajuda, é visível a sua estima pelo escritor: 
Perdoe-me se lhe escrevo uma carta, eu nunca me permiti roubar sua atenção, mas uma vez que já a escrevo, vou aproveitá-la também com outro objetivo. Eu quase nunca consigo expressar e nem expressei-lhe este amor e gratidão que sinto continuamente em relação ao senhor por esta luz que acendeu em minha alma. Sem o senhor eu não saberia nada, haveria o escuro, a confusão, e frequentemente seria tão difícil que eu estaria próximo ao suicídio. E se hoje eu não sou melhor, sou do mesmo modo sórdido e sofro com isto, então em compensação eu sei que há uma luz, que tanto me aquece quanto ilumina, e o sofrimento já não é irremediável, e eu posso viver e me regozijar com uma alegria boa e pura. Posso viver e morrer tranquilamente, sabendo para que "existo". Caro

Lev Nikoláievitch, estou perturbado até as lágrimas ao escrever estas linhas, já que o amo muito, muito, e não consigo dizer tudo isso e nem saberei jamais fazê-lo. ${ }^{94}$ [Tradução nossa]

Tais sentimentos, isto é, toda esta estima e admiração só cresceram cada vez mais daí por diante. E foram suficientes para que Leopold Sulerjítski compreendesse o porquê de Lev Tolstói ter fugido de Iássnaia Poliana, já bastante velho e doente, em 1910. Sulerjítski sabia o quando Lev Tolstói desejava passar tranquilamente seus últimos dias de vida ${ }^{95}$, e talvez tenha sido essa a razão de seu comentário feito durante o seguinte episódio ocorrido na escola de Adáchev na época da fuga de Lev Tolstói e narrado posteriormente por Vakthângov:

\footnotetext{
...nós estávamos sentados ao redor da mesa na classe em uma aula de Sulerjítski.

O palco da escola estava fracamente iluminado.

Na própria sala havia penumbra

Leopold Antônovitch falava baixinho sobre algo.

Súbito passa Adáshev.

- Senhores, Tolstói sumiu de Iásnaia Poliana.

No peito algo se agitou.

Nós não compreendemos nada.

Sulerjítski soergueu-se.

Nós olhamos para ele.

Silêncio.

O rosto de Sulerjítski se iluminou: ele compreendeu.

- Ah, Lev Nikoláievitch, como isso é bom! Como é magnífico! Finalmente, - disse ele entusiasticamente em meio ao silêncio.

Nós todos permanecemos em silêncio.
}

\footnotetext{
${ }^{94}$ A carta já citada neste trabalho. Datada de 4 (16) de julho de 1898. Esta carta, que começa falando de um possível auxílio a ser prestado aos dukhobors, termina com as palavras que citamos a seguir.

${ }^{5} \mathrm{O}$ livro Tolstói. A fuga do paraíso de Pável Bassínski é uma narrativa bastante contundente acerca deste acontecimento.
} 
Ficamos de pé por muito tempo.

E o silêncio foi longo, impregnado, solene e assustador...

[Tradução nossa]

A manifestação desta alegria devido ao sumiço de Lev Tolstói é prova do quanto Sulerjítski compreendia os anseios mais profundos de seu mestre. Ele sabia como era penoso a Lev Tolstói continuar em meio às brigas e desentendimentos diários que ocorriam em Iássnaia Poliana. E que Lev Tolstói precisava encontrar essa paz tão desejada antes de partir para sempre.

Esta compreensão fica ainda mais evidente se olharmos para a carta que Leopold Sulerjítski escreve a Konstantin Stanislávski e sua esposa Lílina dez dias após a morte do Tolstói ${ }^{96}$ :

\section{(...) Tolstói foi enterrado.}

Da última vez, atravessei com ele da estação até a casa por um caminho que eu conhecia entre os bosquetes de bétulas.

Aqui, na encruzilhada do caminho e na estrada de Tula, eu me lembro que o cavalo no qual ele ía estacou e nós trocamos de cavalos. Depois, à tarde, lá na pontezinha, eu me lembro que conversávamos sobre Tchekhov e Górki; estava silencioso, caia a noite e nas isbás os camponeses de Iásnaia Poliana acendiam os fogos e no estreito fosso turvo a água resplandecia, refletindo o céu; estava silencioso, deserto.

Agora aqui esteve o cinematógrafo e matraqueava, fotografava o caixão no qual ele era levado pelos camponeses, um coro de cem rublos bramia o "glória eterna" e entre a multidão negra compactada era visível o bastão com lenço que o regente agitava. Estudantes, universitários, representantes e delegados em paletós pretos com golas de pele de carneiro - todos se fazendo desta forma parecidos uns com os outros - , formavam uma multidão de vários milhares de pessoas se estendendo pelo caminho. Os mesmos responsáveis gritavam "mais espaço, mais espaço", como sempre acontece nos enterros de líderes visíveis, fotógrafos, cinematógrafos, guardas e cossacos pulavam de ambos os lados, surgindo com capotes cinzas entre as bétulas.

Era incomum apenas o montículo de peliças curtas amareladas entre a multidão negra carregando o caixão e indo parcialmente adiante dele. E além disso a ausência dos popes, dos incensos e dos demais atributos.

A multidão não me incomodou, mas na minha opinião, em nenhum lugar ela esteve tão alheia a alguém que enterrou, como esteve alheia a Tolstói. Assim me parecia.

Atrás do caixão, com a multidão comprimida, iam seus amigos, também de sobretudo pretos com golas de pele de carneiro, todos nós, de diferentes cantos da terra nos reunimos, já velhos, com

\footnotetext{
${ }^{96}$ Tostói morreu em 8 (20) de novembro de 1910
} 
cabelo grisalho, com rugas e me pareceu que este rio negro com um caixão amarelo ondulando sobre ele era a própria vida, fluindo como um rio, nos levando também com sua própria correnteza, obrigando com sua potente força a irmos junto com ele por sua corrente, para lá, para onde é preciso ir.

Isso lembrou toda a nossa juventude, todos os nossos ímpetos, os esforços, até os sacrifícios e como isso tudo foi rompido e levado com a torrente da vida, todas as nossas tentativas de ir contra a sua corrente. Como todos enfraquecemos, nos rendemos e nos despedaçamos e corremos com os destroços negros para onde fomos levados. E apenas ele, sozinho e cada vez mais forte, foi continuamente adiante e com toda a força da sua alma até o fim da vida. E apenas morto ele volta atrás, deixando aqui seu corpo, que não pôde amadurecer por trás da alma e que justamente por isso foi por ela abandonado.

Lembro como há muito ele certo dia estava falando sobre o próprio corpo "Habitou em mim este Lev Nikolaievitch e não deixa ir a nenhum lugar; este morador me aborreceu

terrivelmente."

Trouxeram -no para casa e puseram-no naquele quarto onde ele quase se enforcou na viga entre os armários no tempo de sua reviravolta espiritual.

Agora, aquilo que foi L. N. ou aquilo em que estava L.N, jazia silencioso e diante dele iam milhares de pessoas e com uma reverência terrena despediam-se dele passando com a longa fila de uma porta para outra. Eu fiquei de pé junto ao caixão o tempo todo e não conseguia me apartar desta fronte querida, da boca bondosa e oculta pelos bigodes em vida, da mão conhecida, na qual eu conhecia cada unha.

"O grande": assim sentiam-no o tempo todo, ainda mais agora do que durante a vida. Mas quando eu me lembrei de como ele amava as piadas e as canções e de como gargalhava enfiando as mãos no cinto com um riso infantil, diante de mim veio à tona 0 outro, que apenas eu e mais alguns conhecemos. E como foi doloroso perder isso.

O grande ficou e se conservará para sempre e por isso ele não foi perdido, não se foi, mas aquele, o bom, o amigo, o terno e carinhoso, o dócil e paciente já não existe e nem existirá.

Aquele que sofreu, que soluçava cobrindo o rosto com as mãos como uma criança pelo sofrimento espiritual e pelos insultos que suportava para si em casa de pessoas próximas no ano de oitenta e três, aquele já não existe. Não é possível nem acariciá-lo, nem ter pena, nem consolar, nem acalmar.

Ele queria ir embora silenciosamente, imperceptivelmente, sem incomodar ninguém, mesmo que perto do fim da vida sair das condições odiosas para sua consciência, mas foi obrigado a fugir durante a noite, na escuridão, com um homem fiel ${ }^{97}$, fugir não se sabe para onde, por um caminho acidentado, debaixo de chuva, andar sem rumo certo.

Que terrível solidão! Chegar à estação e não saber para onde seguir. Um homem que estava conquistando todo o mundo, um velho de 83 anos, senta-se à noite num apeadeiro longínquo e

\footnotetext{
${ }^{97}$ Provavel referência ao doutor que acompanhou Lev Tolstói em sua fuga. Ver BASSINSKI, Pavel.
} 
fedorento e pensa, para onde fugir: para o sul, o norte, o leste ou o oeste? E foge mais adiante com o primeiro trem, esperando discutir pelo caminho onde buscar abrigo para si. Mas se não souberam amá-lo e protegê-lo, então o que é possível fazer?

E todos nós deixamos escapar este momento pois não o amamos tanto quanto era preciso amá-lo. Vimos nele demasiadamente "o grande" e nos esquecemos do velho, que estava precisando tanto de carinho quanto de amor e atenção. E quando eu me lembrava disso tudo era de maneira dolorosa, vergonhosa e portanto amarga.

Agora todos nós nos reunimos ao redor dele, todos chegaram e ficam olhando o que foi perdido, mas agora nós não somos necessários a ele. É tarde.

Eu encontrei um livrinho no qual ele escreveu: "Para L. Sulerjítski em sinal de amizade - Tolstói”'

E eu até tinha me esquecido de que havia tal livrinho, que havia tal inscrição. Eu lembrava apenas do "grande" e havia esquecido completamente aquele que foi o amigo!

Entre as árvores enormes os mujiques cavaram um profundo buraco, assim à meia versta da casa. Aqui o velho, quando ainda era um menino, brincava com o irmão Nikolenka que ele considerava uma das pessoas mais extraordinárias. Nikolai pegou um pauzinho verde, esculpiu nele uns certos sinais significando que na terra se tornariam todos felizes, as pessoas amariam umas às outras e ultrapassariam toda a desgraça humana, e eles enterraram este pauzinho aqui, sendo que quando o desenterrassem então todos se realizariam desta forma na terra. "Quando eu morrer será preciso me enterrar em algum lugar, então me enterrem aqui, onde está este pauzinho verde, em memória de meu irmão Nikolenka”, assim Falava Lev

Nikoláievitch, passeando ao lado destas árvores. Aqui baixaram o caixão. Logo cobriram com terra, cresceu o montinho, a multidão de vários milhares ficou de joelhos em silêncio. Depois colocaram coroas de louros, vivazes, resistentes. Se amontoaram. No bosque começou a escurecer. A multidão partiu do silêncio para o lugar de onde veio - para a cidade com os bondes, as fábricas e as indústrias - e o silencio reinou. $\mathrm{O}$ bosque enegreceu, reluziam apenas pedacinhos de céu no alto, os topos das árvores murmuravam com um eterno rumor.

$\mathrm{Na}$ escuridão reluziam as faixas no túmulo, tão incompreensíveis neste bosque denso e selvagem. Quando as últimas figuras de preto com golas de pele de carneiro partiram, tornou-se visível que o túmulo estava cercado por uma fileira de cavaleiros cossacos e de guardas. Todos permaneciam imóveis, ao longe, em um círculo cerrado e silencioso. Fez-se ouvir um breve burburinho e de repente o clamor unânime de uma centena de peitos:

- Às suas ordens, vossa excelência! - e levando um eco selvagem pelo arvoredo, conforme me pareceu, todas as árvores simultaneamente estremeceram com este clamor.

"Para casa", estendeu-se uma voz. Ouviu-se um ruído de cascos, o tinido de uma arma e dentro de alguns minutos tudo ficou silencioso. 
Escureceu completamente, a noite avançou com seus farfalhos e suspiros. Ao lado do túmulo acendeu-se uma fogueira e se fizeram visíveis dois mujiques, um velho e um jovem que permaneceram aqui para pernoitar.

Agora já está um silêncio absoluto. Estes não incomodam. Eles são assim como essas árvores, como a própria noite, cobrindo o mundo inteiro com sua negra cortina silenciosa.

Eu fui até a casa, pelo caminho alcancei algumas damas de salto alto que mancavam pela terra gelada coberta por montículos dispersos entre as árvores que ele próprio plantou certa vez.

$\mathrm{Na}$ casa todas as janelas brilhavam. Na sala a mesa comprida, como sempre. Sua poltrona, na qual ele gostava de se sentar, seus retratos, rostos conhecidos à mesa, o conhecido murmúrio.... mas não estão sentados e não estão falando tal como sentavam e falavam quando ele estava aqui.

Percorri todos os quartos, examinei todos os cantos, me sentei em sua poltrona. E assim parecia que agora ele ia entrar.

Todos os velhos amigos do passado se juntaram e calmamente se lembraram dele e decidimos que todos os anos no dia sete de novembro nós vamos nos reunir em sua memória com Alessandra Lvovna.

Depois eu fui embora às doze horas da noite, como sempre ía antes. Mas tive a impressão de que eu já não vou mais voltar lá.

[Tradução nossa]

Conforme procuramos demonstrar neste capítulo, toda a correspondência trocada entre Lev Tolstói e Leopold Sulerjítski, bem como as anedotas e recordações que deixavam um sobre o outro refletem não apenas suas interrelações, como também uma parcela da personalidade de cada um deles, a época em que viviam e os problemas pelos quais a sociedade russa passava. Se vimos neste trabalho um Tolstói preocupado com o amor, a justiça e a igualdade - tal como vemos em outros textos seus já divulgados em língua portuguesa - , não é menos significativo entrarmos em contato com uma das tantas facetas de Leopold Sulerjítski - faceta esta até então desconhecida no Brasil - , que aqui aparece como um homem de ação, com suas próprias convicções, disposto a servir, amar o próximo e fazer o bem. Tais aspectos prenunciam as características centrais que Sulerjítski desenvolverá quando em seus trabalhos realizados no teatro ao lado de Konstantin Stanislávski.

\subsection{Dialogando com K.S.}

Se houve algo que verdadeiramente uniu Konstantin Stanislávski e Leopold 
Sulerjítski foi a maneira como ambos olhavam para o teatro. Tinham consciência de sua missão enquanto artistas. E da necessidade premente de lutar por um teatro no qual o próprio artista tivesse também a consciência desta sua missão.

Em uma de suas anotações de diário, Leopold Sulerjítski fala sobre sua crença num teatro que é templo, e um ator que é sacerdote, quando diz "Faz pouco tempo que o ator se livrou do desprezo, e foi algo muito pequeno, mas antes que ele alcance a condição de sacerdote e o teatro a condição de templo, ainda será preciso fazer muito, muitíssimo (...)"98 (SULERJÍTSKI, 1970, p.372) [Tradução nossa]

Esta ideia do teatro como templo é uma noção bastante cara a Konstantin Stanislávski. Desde suas anotações de 1907 e 1908 Stanislávski fala sobre como nossa vida é suja e grosseira, e como é uma grande felicidade para o ser humano encontrar um lugar onde possa viver para seus melhores sentimentos e desígnios da alma. ${ }^{99}$ Este lugar, que no caso do sacerdote é o altar, não poderia ser outro para o ator senão o próprio teatro.

Foi precisamente por um teatro deste tipo, guiado por um ator-sacerdote com ideias puras, pensamentos elevados e sentimentos nobres que Leopold Sulerjítski e Konstantin Stanislávski lutaram no decorrer de suas vidas. Embora soubessem que ainda seria "preciso fazer muito, muitíssimo" e tivessem a consciência de que muitos atores costumam sujar e manchar precisamente o ambiente que deveriam respeitar e conservar com grande pureza, ambos lutavam por este objetivo de um teatro-templo, de um teatro onde o ator reconhece a sua missão e deseja purificar o seu espaço de trabalho.

Este desejo por um teatro-templo estava ligado à busca pela perfeição. Cada um dos trabalhos que eles realizavam em conjunto era guiado pela sensibilidade artística e pela vontade de manter o valor artístico das obras encenadas, não somente na apresentação da estreia, como em todas as demais. No caso de Leopold Sulerjítski, esta característica é visível desde os primeiros trabalhos que ele realizou como assistente do TAM e pode ser exemplificada com o caso da encenação de $O$ pássaro azul, de Maurice Maeterlink.

A peça já havia chegado à sua septuagésima oitava apresentação quando Leopold Sulerjítski nota que algo está errado. A peça vem perdendo sua força de alguma maneira. O espetáculo, que inicialmente vinha sendo o preferido geral do teatro, tanto dos diretores

\footnotetext{
${ }^{98}$ Anotação sem data. Escruta entre 1913 e 1914.

99 Ver STANISLÁVSKI, K. De las notas sobre ética y disciplina artísticas. In: Trabajos teatrales. Correspondencia. (p.78-98)
} 
principais, quanto dos atores do TAM, sofria agora de uma espécie de "fuga" por parte de todos. $\mathrm{O}$ mesmo elenco que antes pedia insistentemente por um papel, ainda que fosse o menor, agora fugia do espetáculo "como se foge de uma peste", para utilizar as palavras do próprio Sulerjítski.

Para tentar resolver esta questão, Leopold Sulerjítski escreveu um artigo para o "Jornal de espetáculos" em 20 de fevereiro de 1909. Neste artigo, intitulado Septuagésima oitava representação de 'O pássaro azul', ele partiu destes apontamentos para tentar responder a uma questão:

De que maneira manter o valor artístico da interpretação de uma peça que se apresenta tantas vezes como 'O pássaro azul'?

É preciso refletir sobre isso, é necessário elaborar certos meios que possibilitem manter o valor artístico da interpretação da peça; isto é indispensável, urgente e de primeira importância. Na minha opinião, não se trata de uma questão particular, mas do futuro do Teatro de Arte e talvez até mesmo da sua existência.

A glória, o nome e a significação do TAM não se deram imediatamente: foram conquistados com uma luta terrível e para isso foi preciso tempo. Quando trabalhavam no TAM, é pouco provável que esperassem que um pequeno grupo de pessoas que trabalhava em um galpão em Púshkino e atuava no clube de Caçadores, bem como este teatro fosse ter posteriormente tal significação para a história da arte russa e estrangeira, transformando-se numa instituição imensa de quatrocentos homens, com um movimento de meio milhão. Para nós o vigésimo, o trigésimo ou o quinquagésimo espetáculo como que não são importantes: para nós é apenas um "trabalho", quase o cumprimento do serviço militar. E, entretanto, a Rússia vê precisamente estes espetáculos.(...) E o que nós damos?

À exceção de poucos atores do espetáculo (por alguma razão os que tem pequenos papéis) os demais estão gradualmente se tornando não "criadores", mas, como Konstantin Sergueievitch avalia este tipo de intérprete, "informantes" do papel.

E é preciso dizer: informantes muito ruins. Isso nós não podemos ser. As palavras voam com uma velocidade inacreditável, eu escuto apenas o começo da frase e na esmagadora maioria dos casos não escuto o seu final. As deixas chegam antes do término das palavras precedentes; as transições se fazem antes de acontecer aquilo que deve levar a uma ou outra transição.

Juntamente com uma ênfase incrivelmente comum surgem certas entonações místico-enigmáticas de procedência inexplicável. Papéis inteiros são agora conduzidos numa elevação teatral vazia, na qual não há possibilidade de descobrir qualquer sentido.

Geralmente - para me expressar em uma palavra -, por mais que pareça estranho, a ausência surpreendente de conteúdo surge como traço característico do intérprete de cinquenta espetáculos, 
"Makarov-Zemlianski" ${ }^{100}$, como diz Konstantin Sergueevitch. É fastidioso e enfadonho, nada disso é necessário.

O que salva é a fascinação: o Teatro de Arte de Moscou.

Por quanto tempo ela será suficiente?

Toda essa execução medíocre com todo o seu peso pousa sobre uma gaivota fixa a uma cortina de cor cinza.

Não estamos colocando demasiado peso sobre suas maravilhosas, mas frágeis asas? Ela não voaria para longe de nós? Pois ela é um pássaro livre.

Eu me permiti falar de forma ríspida sobre a execução, porque já vi e conheço a autêntica e artística apresentação destes mesmos rostos e até dos mesmos papéis e por isso é meu dever falar disso a vocês da forma que eu entendo. Falo agora, não como o diretor da peça, mas como um colega de ofício, como uma pessoa que estima o teatro.

A salvação do teatro está em tudo o que ele pode colocar no decorrer da temporada de uma mesma peça apresentada 78 vezes, mas também nisso pode estar o perigo da sua destruição, caso não se permita questionar a preservação do trabalho artístico em todos os 78 espetáculos.

Se disserem, o que é comum, que não se pode vivenciar o papel 78 vezes, isso não vai esgotar o assunto. Por que então, por exemplo, Khaliutina, Koonen e Kartsév e outros mais preservaram o desenho da papel em todos os 78 espetáculos?

Por que em N. F. Baleva, apesar de uma ou outra direção, o papel se desenvolve, torna-se mais forte e interessante, enquanto em uma atriz experiente, se dilui e empalidece? Por que após os primeiros espetáculos as observações do diretor quase não se aplicam aos atores?

É necessário debater e repensar todos estes e outros 'por ques' e encontrar respostas para eles. Enquanto não for feito isso, o risco é inevitável.

Me perdoem se não me aprofundei no tema, só citei alguns exemplos tanto do lado positivo quanto do negativo da questão, mas eu só queria ilustrar minha posição sem a intenção de fazer avaliações dos intérpretes isoladamente. Espero que me desculpem. Eu só queria chamar a atenção à gravidade do assunto.

Eu pessoalmente não estou muito convencido de tal necessidade indubitável da existência dos teatros em geral, o teatro não se constituiu na minha vida em alfa e ômega, por isso ainda quero assinalar para um lado da questão, embora talvez vocês mesmos tenham prestado atenção a ela. Pensem, quanto custa fazer um espetáculo, vamos dizer, uma peça como $\mathrm{O}$ pássaro azul?

Quanto nervosismo dos diretores e atores, quanto esforço e períodos difíceis e até crueldades, cabem às pessoas que participam de uma peça (...) As pessoas de noite aplainam numa oficina, soldam alguma coisa, forjam na fumaça da fornalha, os técnicos arruínam seus olhos para toda a vida, trabalhando diante das lanternas de projeção, os pintores definham no sufocante ar das oficinas, respirando o pó tóxico das pinturas, alfaiates, costureiras, moldadores - todo um exército de pessoas, as quais,

${ }^{100}$ Referencia a uma conhecida personagem russa. 
mesmo que não se dediquem à concepção artística de tudo, dão sua vida para a criação da peça. (...) Nós pagamos todos os operários. Não vale a pena falar disso, aqui não é lugar. Só uma evidência - nenhum de nós trocaria de lugar com eles voluntariamente. (...) Tudo está em ordem: a música toca, o veludo preto desce, se levanta, os cronótopos passam rapidamente, os atores falam, gritam e movimentam as mãos.

A fábrica está em pleno andamento.

Por acaso isso não é estranho?

Onde está a vida? Como recuperá-la? Como segurá-la?

[Tradução nossa]

Embora este tópico da dissertação se destine a falar das relações entre Leopold Sulerjítski e Konstantin Stanislávski, é inevitável não parar aqui para fazer parênteses no que diz respeito à semelhança deste texto de Leopold Sulerjítski com o que diz Tolstói no primeiro capítulo de $O$ que é arte, quando entra em questão o fato de a arte consumir muito do trabalho das pessoas sem uma necessidade verdadeira:

De forma que a arte, que consome enorme quantidade de trabalho e de vidas humanas e desfaz o amor entre as pessoas, não apenas não é uma coisa firme e claramente definida, como é entendida de maneiras tão contraditórias por seus amantes, que é difícil dizer o que é geralmente compreendido como arte e, especialmente, como arte boa e útil, em nome da qual os sacrifícios poderiam com justiça lhe ser oferecidos. (TOLSTÓI, 2002, p.27)

Feito este breve comentário, voltemos para a relação estabelecida com

Stanislávski, pois ao ler isso que Leopold Sulerjítski escreveu, Stanislávski colocou-se inteiramente de acordo e expôs isso:

O protocolo expressa maravilhosamente meus receios e tormentos. Será uma pena muito grande se os colegas se referirem a ele com frieza ou hostilidade. (...) Seria um erro pensar que este protocolo é um exagero... (...) E é terrível.... Lev Antonovitch não fala nenhuma palavra sobre negligência, sobre ausência de disciplina, falta de boa vontade. Pelo contrário. Quer dizer, além da disciplina e da ordem há algo a mais que pode arruinar o trabalho artístico...[Tradução nossa]

De fato, Konstantin Stanislávski e Leopold Sulerjítski estavam de acordo em muitos aspectos. Se assim não o fosse, não teriam permanecido tão próximos por tanto 
tempo. Mas vale ressaltar que como em tudo na vida, ambos tinham seus momentos de discórdia.

Exemplo disso é a questão da palavra, exposta em uma página de diário de Leopold Sulerjítski:

STANISLÁVSKI: Mas para que palavras? Sem palavras é possível transmitir com maior sutileza diferentes sentimentos. Por exemplo, que atriz transmitiu em cena sentimentos mais exatos do que Dunkan? Se compararmos Dunkan e Duse, então eu prefiro Dunkan. O teatro deve atingir esta arte e desenvolvêla a tal ponto que transmita tudo sem palavras.

SULERJÍTSKI: Isto está completamente errado. O teatro do drama é aquele tipo de arte cênica, um meio no qual há não apenas os sentimentos, mas também os pensamentos, as ideias: e onde entram os pensamentos, onde o ator deve contagiar o público e reproduzir não apenas os sentimento, mas também os pensamentos, aí a palavra é imprescindível, e além disso, as palavras por si só juntamente com outras formas de expressão dos pensamentos e ideias que as auxiliam, possuem ao mesmo tempo a capacidade de serem belas, é possível aproveitá-las como matéria da arte, como se faz na poesia. Elas tem música, ritmo, estilo de língua do autor, etc, sem falar na voz, este delicado material para a arte. Se as palavras são rudes no palco,nisto os culpados são vocês, as pessoas do teatro, e não a palavra em si. Isto quer dizer que vocês ainda não encontraram um modo de pronunciar as palavras, expressar os sentimentos e pensamentos com as palavras.[Tradução nossa]

A partir daí, Leopold Sulerjítski, que polemiza com Konstantin Stanislávski desde a primeira linha, continuará a tratar desta questão, desenvolvendo argumentos para defender seu posicionamento. Falando sempre sobre algo que lembra muito as palavras de Nemiróvitch-Dánchenko em “La experiencia del actor” (1990):

$\mathrm{O}$ ator tem deixado a palavra muito abandonada. É necessário aprender a fazer com que a palavra chegue, 'servi-la' ao público. Se traduzirmos para a linguagem teórica, temos que dizer que na base de toda a educação do ator falta moldar em palavras tudo aquilo que chamamos de vivência. [Tradução nossa]

Muito poderia ser dito aqui sobre a questão da palavra no teatro. A coletânea $O$ signo teatral. A semiologia aplicada à arte dramática (1977) é um exemplo. Contando com artigos de Ingarden, Bogatyriov, Honzl e Kowzan, 4 estudiosos da semiologia, esta coletânea apresenta as mais variadas visões da questão da palavra no teatro. Enquanto para Ingarden a palavra ocupa lugar central junto ao público, para Bogatyriov o teatro é uma arte signica por 
excelência e não precisa essencialmente da palavra para existir - uma visão que estaria mais próxima a de Stanislávski no caso desta página de diário a que recorremos.

Mas se Bogatyriov está de alguma forma próximo a Stanislávski por seu pensamento neste momento especifico, que fique claro; pois Stanislávski posteriormente também dará grande atenção à questão da palavra - , é Tadeus Kowzan quem mais se aproxima do pensamento de Leopold Sulerjítski quando diz que "a entonação da voz do ator, a maneira de pronunciar essa palavra, pode modificar o seu valor. Há muitas maneiras de pronunciar as palavras 'eu te amo', que tanto podem significar paixão como indiferença, ironia ou lástima."

O ponto de contato com a noção apresentada por Kowzan é evidente, pois aqui nenhum deles trata especificamente das palavras de que o ator se utiliza, mas da maneira como o ator se vale de tal ou qual palavra. Assim, se existem milhares de maneiras de se dizer uma frase como "Eu te amo", caberia ao ator descobrir qual a melhor forma de fazer com que estas palavras saltassem do texto dramático e ganhassem vida numa mesma representação. Evidentemente, neste sentido, não se trataria de desistir da palavra em si, mas tão somente de saber aplicar este signo da maneira mais adequada às propostas de determinado espetáculo, já que renunciar ao uso da palavra ou dizer que a mesma atrapalha o ator,

Seria como se Dunkan dissesse que as danças e os movimentos com as pernas no balé a atrapalham ao transmitir suas sensações; e por isso renunciasse aos gestos e poses. No entanto, ela não fez isso, pois justamente isto também é materia de sua arte. Ela desistiu de "tais gestos" e encontrou novos, próprios, encontrou um novo modo para o gesto e movimento. Ela estudou o gesto e a pose em Botticelli na antiga escultura e etc. e encontrou. (SULERJÍTSKI, Leopold, 1914)[Tradução nossa]

Caberia ao ator, portanto, buscar o sentido da palavra ao passá-la para sua boca. Digeri-la, compreendê-la, e não apenas degluti-la ou cuspi-la fora, sem sequer pensar sobre aquilo que significa. Simplesmente refletir: eis aqui para o que apela Leopold Sulerjítski. Pensar sobre o ritmo de elocução no momento de falar. Algo que, talvez não por acaso, está presente também com grande força em seu texto sobre a septuagésima oitava apresentação do pássaro azul. 
De fato, por mais que houvesse uma profunda coincidência no pensamento de ambos, havia também algumas divergências. E isso não é visível apenas nesta página de diário, como também no texto do teatrólogo Rudinítsky, quando lemos que ambos olhavam para o Sistema de maneira diferente. Enquanto para Stanislávski o Sistema era um meio de estímulo à "própria natureza" do ator, responsável por garantir a "vida natural do espírito humano", para Sulerjítski ele possuía um significado muito mais amplo e profundo, inclusive até "mais universal, radical e pacificador: para ele o 'Sistema' tornava-se um instrumento de aperfeiçoamento moral de todos os que o estúdio unia, nem mesmo tanto na cena quanto na vida. (RUDNITSKY, 1970, p.178) [grifo do autor. Tradução nossa]

Rudnitsky fala em seu texto sobre o fato de Leopold Sulerjítski ter dado uma entrevista certa vez, na qual respondeu que as atividades realizadas no Estúdio consistiam em desenvolver a psicologia de criação do ator, formar o estado geral do ator e aproximar ator e autor. Esta sua resposta à imprensa, no entanto, não coincidia com a realidade, já que suas relações diárias com os estudantes apresentavam estímulos completamente diferentes dos citados na entrevista. No dia a dia do estúdio, cada trabalho ou atividade realizada surgia não tanto com o sentido de desenvolver a psicologia ou o estado geral do ator, mas muito mais do que isso, com a intenção de estabelecer uma atmosfera moral.

De acordo com Rudinitsky:

Tão forte pressão para a ética era para Sulerjítski não apenas natural, como também, inclusive, inevitável. É conhecida a sua lealdade estóica ao tolstoismo, às ideias tolstoistas da teoria da não violência, à fé de Tolstói na honestidade e bondade natural do homem, na civilização deformada e na necessidade "de interrogar". Deveras, a ética missionária de Suler foi absolutamente despojada de fanatismo e de intolerância sectária. Pelo contrário, este foi um homem claro, simples, sincero e irresistivelmente encantador (no final das contas até mesmo Nemirovitch chegou a dar-lhe crédito) ${ }^{101}$. Não obstante, a percepção de Suler do "Sistema", no qual ele acreditava profundamente e o qual ardorosamente propagandeava, divergia completamente dos objetivos fundamentais de Stanislavski. (RUDINITSKY, 1970, p.178) [Tradução nossa]

Esta diferença se dava pelo fato de Leopold Sulerjítski ter suas próprias convicções e, no caso do Estúdio, enxergar como objetivo final o teatro-contato, a

\footnotetext{
${ }^{101}$ Ele inicialmente não gostava de Sulerjítski.
} 
comunhão de atores. Conforme diz Smishliaev: "E nos seus sonhos com a mais elevada forma teatral cada vez com mais e mais frequência surgia uma imagem de uma organização particularmente pura e intensa: a comuna de atores, no sentido em que Sulerjítski compreendia esta palavra.” (Smychliáev, 970, p.581) [Tradução nossa]

Ainda assim, Rudnitsky reconhece o pensamento comum existente em ambos já que o caráter formador do Estúdio e o trabalho com as diferentes individualidades não eram desejo de apenas um dos dois:

\begin{abstract}
A ideia era uma só, clara e definida: a formação do ator, a verificação experimental das captações do "Sistema" e seu aperfeiçoamento. Particularmente, sua perspectiva atraia improvisações dos atores, sendo que Stanislávski especificamente explicava que de maneira alguma tinha em vista "o objetivo de renovação da história da commedia dell'arte", não, dizia ele, "nós queremos cultivar o processo da 'vivência' na improvisação. (RUDNITSKY, 1990, p.180) [Tradução nossa]
\end{abstract}

Afinal, ambos se complementavam nesta caminhada. E se, como diz Elena Poliakova, Stanislávski era o estrategista enquanto Sulerjítski era o tático, era preciso que trabalhassem em conjunto para que o Estúdio evoluísse. Se havia desavenças? Claro que havia. Olga Sulerjítskaia conta como certa vez Leopold Sulerjítski chegou mais cedo de um ensaio de $O$ pássaro azul visivelmente abalado, sentou-se e disse para si mesmo: “ Que ele mesmo dirija.... Como quiser, que faça o que quiser." Mas pouco tempo se passou e lá veio a babá dizendo que Konstantin Stanislávski havia vindo visita-los. Claro que não demorou muito para os dois estarem novamente conversando como antes.

A este respeito, diz Olga Sulerjítskaia (1970, p.544) "Claro que as relações deles não foram u idílio ininterrupto: houve sérias divergências de opiniões e ofensas, mas com os anos a amizade deles se fortaleceu e o trabalho criador em conjunto uniu-os ainda mais um ao outro."

Tanto, que além da admiração mútua, Milkhail Tchekhov conta como:

Quando Sulerjítski morreu, o caixão com seu corpo ficou em nosso estúdio.

Após o enterro, Stanislávski estava entre os que falariam sobre ele na cerimônia fúnebre.

Ele estava pálido e seus lábios tremiam.

Não terminou o seu discurso e, contendo os soluços, ele correu até os bastidores da nossa pequena cena. (TCHEKHOV, 1970, p.610) 


\section{Capítulo 3 LEOPOLD SULERJÍTSKI - OLHAR PEDAGÓGICO}

\subsection{Uma rápida conversa}

Em Moscou há uma centena de teatros. E praticamente todos eles levam consigo o nome de algum dramaturgo ou encenador russo famoso: Teatro de Arte de MoscouTchekhov; Teatro de Arte de Moscou Górki; Teatro Meyerhold; Teatro Vakthângov;, Eletro-Teatro Stanislávski; Teatro... e assim por diante. O que certamente ocuparia mais de uma página deste trabalho se eu resolvesse citá-los todos.

Mas não demorou muito e eu já começava a me indagar: "E o teatro Sulerjítski? Onde está?"

Em minha última semana de viagem lá estava eu, sentada em uma das várias salas do Instituto Estatal de Arte com meu bloquinho de anotações de sempre, pronta para fazer esta pergunta ao professor Dr. Vladislav Ivánov, com quem eu logo iria conversar.

Ele chegou.

Nós conversamos.

Tomei coragem e perguntei o porquê desta ausência inexplicável.

"Porque o papel de Leopold Sulerjítski" respondeu o professor após ouvir minha pergunta "foi muito mais significativo no que diz respeito à pedagogia, do que à encenação. Aí está o livro Pedagóguika isskustva para comprovar isso. Esse livro é uma forma de reconhecer o seu papel pedagógico”. E nossa rápida conversa acabou.

Fomos embora, eu e o meu bloquinho.

Eu já havia lido isso em Pável Márkov: "Mais professor da vida do que professor da cena”. E já sabia da existência deste livro, o qual eu havia encontrado na Biblioteca Lenin no mês anterior (Um livro inteirinho escrito em memória da pedagogia teatral de Leopold Sulerjítski e publicado em 2013). Eu só ainda não havia ligado a falta de um teatro com seu nome ao seu grande valor pedagógico. E deveria?

A conversa com o professor Dr. Vladislav Ivánov me deu muito em que pensar. E resolvi dedicar este último capítulo à exposição daquelas que me pareceram ser as mais importantes lições deixadas por Leopold Sulerjítski durante o seu trabalho como professor na Escola de Adáchev e no Primeiro Estúdio: a fé, a união, o amor. E sobretudo, a humanidade. 


\subsection{Mestre apenas de teatro?}

Em carta escrita a Leopold Sulerjítski em 6 (18) de setembro de 1910, Konstantin Stanislávski diz "Estou muito feliz que nosso Sistema entre no seio do Teatro de Arte; pelo amor de Deus, ocupe-se com a pedagogia, o senhor tem grande aptidão para ela. O senhor não pode imaginar que vantagem traz ao Teatro de Arte e como isso o liga fortemente a ele.” (STANISLÁVSKI, in: SULERJÍTSKI, 1970, p.463) [Tradução nossa]

Para entendermos este apontamento, é preciso lembrarmos em primeiro lugar que a palavra pedagogia surgiu na Grécia Antiga como a superação de um pensamento anterior. Ou seja, se a educação até então compreendia a noção de imitação dos mais velhos como algo central, com a pedagogia surge a noção do homem questionador, que reflete por si mesmo e se coloca na sociedade ao invés de apenas imitar os demais. (BOHM, 2010, p.13-5)

Corroborando para este pensamento, Maria Lucia de Arruda Aranha (2006, p.67), diz que os povos da Antiguidade não refletiam especificamente sobre a educação, dado estarem vinculados às tradições religiosas recebidas de seus ancestrais. Assim, a educação relacionava-se inteiramente à religião e os depositários dos valores a serem passados eram os sacerdotes, os magos e os escribas. Até que esta situação mudou de figura com o aparecimento da pedagogia:

\footnotetext{
...as explicações predominantemente religiosas foram substituídas pelo uso da razão autônoma, da inteligência crítica e pela atuação da personalidade livre, capaz de estabelecer uma lei humana e não mais divina. Surgia, pois, a necessidade de elaborar teoricamente o ideal de formação, não do herói, submetido ao destino, mas do cidadão, que deixa de ser o depositário do saber da comunidade para se tornar aquele que elabora a cultura da cidade. A ênfase no passado foi deslocada para o futuro: ninguém se acha preso a um destino traçado, mas é capaz de projeto, de utopia. (Ibidem) [grifo nosso]
}

Leopold Sulerjítski era um sujeito livre. E desejava que os demais ao seu redor o fossem também.

Tanto é que expõe isso de várias maneiras ao longo de sua trajetória teatral. Em seu caderno de anotações conservado pelo Museu do Teatro de Arte de Moscou Sulerjítski há uma anotação na qual ele diz que: "Inicialmente a peça [que vai para o Estúdio] é feita até o fim com total independência, sem qualquer participação do diretor 
princ.[ipal]".[Tradução nossa] Ou seja, cada indivíduo se encontra suficientemente livre para criar, jogar e experimentar.

Esta ideia de liberdade de criação foi um dos pilares do Primeiro Estúdio do Teatro de Arte de Moscou. O fato de a formação dos atores não contar com um texto dramático a ser seguido desde o início trouxe um caráter inovador para o desenvolvimento do ofício do ator. Era preciso que houvesse a auto exploração. O improviso, os jogos. O trabalho do ator sobre si mesmo, o exercício, a imaginação, o treinamento. Cada um destes pontos tornava-se gradualmente parte integrante do trabalho do ator e isso constituiu uma grande revolução para o teatro do século $\mathrm{XX}$, auxiliando consideravelmente no desenvolvimento da pedagogia-teatral.

Em "Semiótica de la escena"102 Iuri Lótman já aponta o caráter significativo que há neste tipo de atividade. De acordo com sua definição, o jogo pressupõe a realização de uma conduta prática e sígnica simultaneamente, tendo assim um caráter não monossêmico. Com isso, aquele que joga tem plena consciência de que se encontra em uma esfera lúdico-convencional e, portanto, tudo o que faz encontra-se no plano da imaginação, do "como se": é como se caçasse, como se viajasse, como se navegasse. ${ }^{103}$ Elena Poliakova traz para seu livro um pouco desta mágica experiência vivida no Estúdio quando diz que:

No estúdio Suler ou Vakthângov dão um tema para o improviso, determinam um tempo. Vocês viverão meia hora ou quarenta minutos nas circunstâncias propostas. Vocês são Robinsons, lançados na beira do mar. Piratas, que encontraram um baú de tesouros. Patrões, trabalhadores emporcalhados até o chapéu ou que estão na oficina de alfaiates. Ou de calçados. Ou trabalhadores de uma funerária. Ao se reunirem sejam livres, saudáveis e alegres. De manhã se olhem no espelho, façam exercícios físicos. No Estúdio-contato eu sou: este sou eu. Improvisar livre, leve e pronto: onde? Na alfaiataria. Com quem? - Com o velho alfaiate, sentado a vida inteira com agulha e linha, tesouras, um pedaço de tecido novo ou um sobretudo rasgado. Com um patrão (uma patroa), com uma mestra mais velha, com uma mocinha entregue aos estudos. Ocupar-se com uma ação, com todos os que estão aqui. Aliás, é possível se exercitar com objetos invisíveis. Passar com um ferro imaginário - de forma que o espectador acredite em seu peso, em sua temperatura, no fato de que vocês queimaram um dedo - ou enfiar uma linha invisível numa agulha imaginária ; o número é conhecido a partir do momento em que aparecem a linha e a agulha. Ao mesmo tempo bebe-se de um copo ilusório, come-se uma maçã ou uma laranja invisível, ou toma-se uma sopa

\footnotetext{
${ }^{102}$ In: Semiosfera III pp.57-84

${ }^{103}$ Exemplos retirados do proprio texto de Lótman.
} 
fervente : como se houvesse uma colher, como se houvesse uma tigela. (POLIAKOVA, 2006, p.183) [Grifo do autor, Tradução nossa]

Mas ainda que estivessem sujeitos a esta total liberdade para a criação, os alunos contavam com a participação de Sulerjítski enquanto orientador e guia do Estúdio. De maneira que seu caderno de anotações conta com a seguinte observação:

$\mathrm{O}$ diretor princ. tem o direito de entrar em quaisquer trabalhos no Estúdio, em todos os ensaios. (...) O direito de fazer observações, no sentido pedagógico, aos intérpretes e ao próprio diretor no que se refere à compreensão dos caminhos pelos quais se realizam os ensaios. (SULERJíTSKI, Arquivo do Museu do TAM) [Tradução nossa]

A sua função, ele sabia, era guiar os jovens do Estúdio. Mas isso, de forma tênue. Isto é, sem impedir que os jovens estudantes olhassem para onde desejassem, mas precisamente apontando quais os melhores caminhos, quais as possibilidades existentes, abrindo seus olhos para algo que talvez eles ainda não tivessem percebido ao seu redor, tanto no momento dos jogos, quanto no momento da criação dos personagens de determinada peça teatral.

Não à toa ele escreve em seu diário em 4 (16) de abril de 1914:

O diretor precisa inflamar-se pelos personagens e pela peça, mas ser paciente e compreender que antes de tudo ele é um espelho - nisto está o essencial de sua destinação - , e todo o seu grau de saturação pelos personagens, o entusiasmo pela peça, o seu arrebatamento criador é nada mais do que um amálgama, graças ao qual ele pode ser um espelho, e não um vidro oco que não consegue refletir nada e portanto é inútil. (SULERJíTSKI, 1970, p.349)

[Grifo do autor. Tradução nossa]

Durante a criação, portanto, não caberia ao diretor o papel de frustrar todo "o encanto e frescor do trabalho criador do ator, deixando-se arrebatar por seu papel, explicando-o muito e com fervor, mostrando-o, criando.”(Ibidem) [Tradução nossa] Pois, nas palavras de Sulerjítski, se o diretor "faz isso mal, é simplesmente uma perda de tempo; se faz bem, o ator se vê privado da alegria da primeira união da sua alma com o 
papel e começa a copiar aquilo que o diretor conseguiu; e isto também e ruim, muito ruim."(Ibidem) [Tradução nossa]

Também Vladimir Nemiróvitch-Dántchenko toca neste ponto do diretor como espelho, em seu artigo "As três caras do diretor de cena" (1936). Para ele, a principal habilidade do diretor espelho consistiria em sua percepção da individualidade do ator, a busca pelo entendimento daquilo que está bom ou ruim cenicamente e a observação quanto ao fato de as intensões do autor e do próprio diretor estarem ou não refletidas em cena. Além disso, caberia ao diretor-espelho "observar e dirigir a vontade do ator, sem que ele se conscientize disso; e ser capaz de imitá-lo sem causar-lhe humilhação, senão com amor e amizade (...) de tal modo que o ator possa ver-se cara a cara, como um espelho." 104 [Tradução nossa]

Era o que Leopold Sulerjítski buscava fazer em seu trabalho.

Em suma, desde o momento em que ingressou em Adáchev e passou a se dedicar à pedagogia dentro do teatro, Leopold Sulerjítski lutou para que seus alunos criassem, sendo ele apenas o espelho, ou, para usarmos uma terminologia de Konstantin Stanislávski, o diretor-obstetra ${ }^{105}$.

Exemplo disso são os apontamentos do ator A. Díki (POLIAKOVA, 2006, p.193) sobre os ensaios de "O naufrágio do Esperança", primeira grande encenação realizada pelo Estúdio:

\footnotetext{
${ }^{104}$ NEMIRÓVICH-DÁNCHENKO, Vladimir. "Las tres caras del director de escena” p.106

105 "O diretor. Seu papel na criação do ator pode ser comparado com o trabalho de um obstetra. Tudo é feito nem pelo ator, nem pelo diretor, mas pela natureza. $O$ ator é a mulher em parto, o diretor é o obstetra. Ele dirige o andamento correto do trabalho do parto. No momento crítico ele corrige o feto que está na posição errada ou aplica o fórceps." (STANISLÁVSKI, in: VASSINA, E. E LABAKI, A. 2015, p. 150)
} 
como Vladimir Ivanovitch, ele possuía não menos intuição do que aquele, e a nobreza de sua alma gravava sua marca em cada espetáculo com o qual ele chegava a ter contato. Eu penso que a pureza da atmosfera do "Esperança" era em grande medida um reflexo da personalidade desse homem maravilhoso. [Tradução nossa]

Mas se Leopold Sulerjítski desejava dar liberdade e além disso auxiliar seus alunos na direção que deveriam seguir, era preciso que ele tivesse em primeiro lugar uma palavra que deve acompanhar todo aquele que deseja seguir pelo caminho da pedagogia: experiência.

O texto $O$ narrador. Considerações sobre a obra de Nikolai Leskov, escrito pelo filósofo alemão Walter Benjamin traz uma abordagem fundamental acerca desta pequena palavra, tão importante e ao mesmo tempo tão esquecida em nosso tempo.

Este texto fala do verdadeiro narrador como sendo aquele que possui experiência de vida para passar a seus leitores ou ouvintes. Aponta-se aqui para o fato de que é cada vez mais difícil nos depararmos com um narrador de verdade, já que "as ações da experiência estão em baixa e tudo indica que continuarão caindo até que seu valor desapareça de todo.’(BENJAMIN, 1985, p.198)

A experiência passada de pessoa para pessoa é até hoje utilizada como o manancial de grandes narradores. E de acordo com Benjamin,

...entre as narrativas escritas as melhores são as que menos se
distinguem das histórias orais contadas pelos inúmeros
narradores anônimos. Entre eles existem dois grupos, que se
interpenetram de múltiplas maneiras. A figura do narrador só se
torna plenamente tangível se temos presentes esses dois grupos.
'Quem viaja tem muito o que contar', diz o povo, e com isso
imagina o narrador como alguém que vem de longe. Mas
também escutamos com prazer o homem que ganhou
honestamente sua vida sem sair do seu país e que conhece suas
histórias e tradições. Se quisermos concretizar esses dois grupos
através dos seus representantes arcaicos, podemos dizer que um
é exemplificado pelo camponês sedentário e outro pelo
marinheiro comerciante. (BENJAMIN, 1985, p.198)

Curiosamente, Leopold Sulerjítski havia sido tanto camponês quanto marinheiro antes de entrar para o teatro. O que logicamente não significa que por conta disso ele tivesse a obrigação de ser um bom narrador. No entanto, como revelam relatos de seus contemporâneos, ele era. Os relatos de sua esposa, de Tolstói e de seus familiares, dos 
alunos do Estúdio, e de Konstantin Stanislávski estão aí para comprovar este fato. Stanislávski fala sobre o dom natural que Sulerjítski tinha para falar com todos, desde as pessoas mais simples até as de um nível mais elevado, de quem ele conseguia chamar a atenção de alguma forma. Isso porque

Ele sabia falar com seriedade. E suas palavras eram tanto mais convincentes porque ele falava sobre muitas coisas não por ter ouvido, mas por tido sua própria experiência difícil ou alegre. Sim, ele tinha sobre o que contar, sobre aquilo que não se encontra nos livros. Ele tinha sobre o que falar, já que tinhaideias e pensamentos que construía para falar. Tinha o que propagar, visto possuir objetivos em prol dos quais vivia. Tinha com o que sonhar, já que sempre buscava o melhor e o mais elevado. (STANISLÁVSKI, 1970, p.548) [grifos do autor, tradução nossa]

Se o papel da experiência é fundamental no que diz respeito ao narrador, o que então dizer do professor? Este, que deve passar um saber para seus alunos fazendo com que eles se interessem por conhecer a bagagem que traz consigo; que deve mostrar a utilidade do que ensina e fazer com que o aprendizado se torne sempre mais e mais prazeroso a todos os envolvidos. Pois bem. Não teria ele também, isto é, o professor, uma necessidade premente de trazer consigo a experiência e espalha-la entre seus alunos?

Leopold Sulerjítski foi realmente este professor dotado de uma grande bagagem de vida, uma bagagem artística e cultural. E foi justamente este fator que trouxe um frescor para o universo teatral, conforme relatado por Konstantin Stanislávski ao recordar-se do amigo:

Súler trouxe consigo, diretamente da terra para o teatro, uma imensa bagagem de material fresco da vida espiritual. Ele recolhia bagagem por toda a Rússia, que percorria em todos os sentidos com uma sacola nos ombros; por todos os mares que ele atravessou mais de uma vez, por todos os países que ele visitou na época de suas viagens ao redor do mundo e outras. Ele trouxe para a cena a verdadeira poesia da pradaria, do campo, das florestas e da natureza, observações da arte e da vida, pensamentos e objetivos obtidos por provações e pontos de vista éticos, filosóficos e religiosos originais.

Trouxe uma relação inocente e pura com a arte, devido à completa ignorância das técnicas velhas, sujas e desgastadas do ofício do ator, com seus clichês e estereótipos, com sua beleza aparente no lugar do belo, com sua tensão no lugar do lirismo e com a extravagante recitação no lugar do verdadeiro entusiasmo do sentimento elevado. 
Súler trouxe consigo uma posição livre e ampla para a arte teatral... (STANISLÁVSKI, 1970, p.549) [Tradução nossa]

Neste sentido, quando pôs-se a trabalhar com Stanislávski primeiramente no TAM, depois em Adáchev e por fim no Primeiro Estúdio, este pedagogo, camponês e marinheiro experiente, não poderia senão agregar algo de utilidade ao conjunto do qual agora fazia parte. E isso, em todos os sentidos. Inclusive com as encenações realizadas.

Diante disso, o texto dramático "O naufrágio do Esperança" de Herman Heijermans, sobre o qual se falou mais acima, veio a calhar para Leopold Sulerjítski, sendo prova definitiva de que toda a sua bagagem era consideravelmente útil e necessária para o fazer teatral.

Em estilo naturalista, esta peça segue a linha dos demais textos escritos por Heijermans, trazendo um forte sentimento de humanidade, o retrato da vida das pessoas comuns e a denúncia de problemas sociais (DUKES, p.6). Este drama do mar em 4 atos conta a história de pessoas simples que vivem numa vila de pescadores e em sua grande maioria são vítimas da seguinte situação: para conseguir seu sustento têm de trabalhar para homens que não se importam em mandar barcos deteriorados (os "caixões flutuantes", como dizem as personagens) para o mar em busca de peixes; em vista disso, não é raro que os barcos quebrem durante a viagem e os homens não voltem, sendo engolidos pelo mar como se eles é que fossem os peixes - para usar a ideia do personagem Cobus quando fala acerca do medo da morte: "Eu digo: nós pegamos o peixe e Deus nos pega.”. (Em: The Good Hope, p.68) [Tradução nossa]

O texto de Heijermans trazia em si temas com os quais Leopold Sulerjítski já havia convivido ou sobre os quais refletia em seus escritos: a questão do poder e da falta de humanidade - algo muito evidente no último ato, quando as famílias descobrem que o Esperança afundou e vão atrás de notícias, mas tudo o que conseguem é uma certa frieza por parte dos responsáveis pelo barco ${ }^{106}-$, os personagens revolucionários, os maus momentos vividos por Geert durante o tempo em que esteve preso e, principalmente, a vida no mar.

\footnotetext{
${ }^{106}$ O maior exemplo talvez seja o caso da viúva Kneirtje, uma das personagens centrais da peça. Ela, que já havia perdido marido e filhos há cerca de 12 anos num naufrágio, perde seus últimos dois filhos agora, com o fim do Esperança. Quando vai ao escritório de Clemens Bos, tudo o que ouve é que sentem muito e que ela não ficará desamparada. Terá seu emprego de faxineira novamente. E, a propósito, "If you will return the dish when it's conveniente, and if you'll come again Saturday, to do the cleaning" (p.103)
} 
Por ter sido marinheiro Leopold Sulerjítski evidentemente podia falar sobre determinados aspectos da peça com uma certa autoridade que os outros do Estúdio não tinham. Elena Poliakova (2006, p.194) escreve sobre este fato, contando como durante a preparação desta peça, levada ao Estúdio por Richard Boleslávski,

\footnotetext{
Súler transmitia aos estudantes a sua memória das guardas, da direção da roda do leme, o sussurro das velas e o assobio do vento nos cordames; transmitia tão natural e imperceptivelmente, que os estudantes tinham a impressão de que eles mesmos se lembravam, sabiam de tudo e reviviam na cena.

A compaixão teatral do tipo "Ah, pobres marinheiros" não surgia no trabalho. Cada um encontrava [algo] em sua própria imagem, voltando-se à própria memória afetiva na qual havia despedidas e inquietações pelos próximos e novos encontros. [Tradução nossa]
}

Mas então quer dizer que basta ser experiente em algo para se tornar um bom professor? Que basta ter vivido no mar para poder falar sobre ele?

Óbvio que não.

Se pararmos para pensar, porém, há aí duas questões que podemos apontar. Em primeiro lugar, sobretudo numa época em que as fronteiras eram muito maiores do que aquelas que temos hoje, naturalmente o fato de ele ter tido experiências como marinheiro era um grande diferencial, auxiliando, e muito, na criação de um trabalho onde todos os personagens viviam rodeados pelo mar, tendo seus sonhos e suas vidas por ele diariamente arrebatados.

Em segundo lugar, o que é ainda mais importante, a um bom professor cabe não apenas saber sobre algo, mas também e sobretudo, saber como passar este algo adiante para seus alunos. Portanto, não nos referimos aqui ao fato de Leopold Sulerjítski ter apenas experiência de vida - o que ele tinha, e muito - , mas ao fato de ele saber precisamente como passar esta sua experiência aos alunos, como alcançar o coração de seus ouvintes e, acima de tudo, como extrair de cada um a experiência pessoal que carregava consigo.

A partir do momento em que os alunos não utilizavam aqui as experiências vividas pelo professor, mas apenas partiam delas para revelar as suas próprias, estavam realizando o tão sonhado trabalho do ator sobre si mesmo. Algo de que Konstantin Stanislávski falará mais tarde também ao criar seu método das ações físicas, alegando ser 
preciso ao ator partir de si mesmo, pois é muito mais difícil digerir a experiência de outro, do que criar algo próprio, próximo à mente e ao coração. É precisamente isso que Leopold Sulerjítski vai incorporar em seu trabalho no estúdio, já que ele via o teatro como este lugar onde "é necessário alcançar uma alma alheia, revelá-la com cuidado, apaixonar-se obrigatoriamente por ela e acolhê-la, quer dizer, revelar-se também a si." ${ }^{107}$ (SULERJÍTSKI, 1970) [Tradução nossa]

Era o que ele fazia. Mas sem utilizar terminologias que complicassem a vida de seus alunos - o que evidentemente poderia ocorrer devido à terminologia empregada no Sistema ${ }^{105}$. Essa sua característica de buscar a simplicidade no momento de ensinar, não apenas contribuía para o desenvolvimento geral de todos, como também era em grande medida apreciada por Konstantin Stanislávski, para quem:

Súler foi um bom pedagogo. Ele conseguia explicar melhor do que eu aquilo que minha experiência artística havia me sugerido. Suler amava a juventude e ele mesmo era uma alma jovem. Era capaz de conversar com os alunos, não os assustando com os saberes científicos, perigosos para a arte. Isso fez dele um excelente guia do assim chamado 'Sistema', ele formou um pequeno grupo de alunos nos novos princípios de ensino. Este grupo entrou no núcleo do Primeiro Estúdio, que nós fundamos juntos. A esta tarefa ele entregou suas últimas forças criadoras, administrativas, morais e pedagógicas. Aqui, nestas paredes, ele deixou uma grande parte do seu coração. (STANISLÁVSKI, 1970, p.550-1) [Tradução nossa]

Sobre esta sua característica, fala também Mikhail Tchekhov (1970, p.607), que relembra em suas recordações como:

$\mathrm{Na}$ época do trabalho com "O grilo na lareira", Leopold Antónovitch (ele participava de todas as apresentações como diretor de arte) revelou-nos a essência desta obra de Dickens. Como ele fez isso? Não com discursos, não com explicações, não com a interpretação da peça, mas transformando-se pessoalmente em um tipo dickensiniano na época do trabalho, precisamente em Caleb Plummer, o fazedor de brinquedos.

Não penso que ele tivesse consciência desta transformação em si. Ela surgia nele por si só, natural e verdadeiramente, assim como em tudo o que ele fazia.

\footnotetext{
${ }^{107}$ Anotação deixada em seu diário. Este diário, como já mencionado anteriormente, encontra-se traduzido na íntegra e incluído como anexo neste trabalho.

105 "Ação", "'Se' mágico", "circunstâncias propostas", "Memória emocional", "trechos e tarefas", para citarmos alguns exemplos.
} 
A sua presença nos ensaios criava aquela atmosfera que tão fortemente transmitiu-se depois ao público e que consideravelmente contribuiu para o sucesso do espetáculo. [Tradução nossa]

Fosse encarnando algum dos personagens de Dickens, fosse impregnado o ambiente com uma atmosfera de amor, aconchego e humor, ou, como conta Mikhail Tchekhov, convidando os alunos para tomar um chazinho após o ensaio, Leopold Sulerjítski fazia com que esta peça fizesse realmente parte da vida do Estúdio.

Muito diferente, porém, foi a atmosfera que Sulerjítski levou para a peça "A festa da paz”, de Gerhart Hauptmann. E talvez não pudesse ser de outro jeito, já que o texto de Hauptmann está envolto em um clima completamente diferente do conto de Dickens. A peça em três atos conta o drama vivido pela família Sholz, na qual todos praticamente não se suportam devido a certos acontecimentos de seu passado em comum.

Quando a peça tem início e a família Scholz decora a árvore para o natal, nada leva a crer ainda que todos vivam uma vida tão infeliz. Gradualmente, porém, descobrimos que o dr. Fritz Scholz, pai da família, foi embora da casa há cerca de seis anos sem explicar a razão; que seu filho Wilhelm partiu igualmente na mesma época, sentindo-se culpado pelo fato de ter batido no pai; que ele e os dois irmãos, Auguste e Robert, guardam rancor por terem tido um pai tão ruim, o qual não os amava e além do mais trancava os filhos durante horas em um quartinho onde eles deveriam apenas estudar, quando na verdade eles ainda eram crianças e preferiam brincar; que Robert sente inveja do irmão Wilhelm e tenta colocá-lo contra a noiva Ida; que a senhora Scholz se ocupa apenas consigo e reclama repetidas vezes de seus filhos, acreditando que a filha da senhora Buchner é muito melhor do que os seus; e por fim, que todas as mágoas do passado não foram superadas e estão prestes a explodir a qualquer momento.

Até que a explosão fatalmente acontece. E no final do segundo ato, quando toda a família se encontra reunida pela primeira vez em tanto tempo ${ }^{108}$, acontece a terrível cena que dá origem à interpretação histérica ocorrida dentro do Estúdio e já abordada no primeiro capítulo desta dissertação. Aqui, após ter havido uma cena reconciliação momentânea, onde pai e filho pareciam ter se perdoado, onde Wilhelm sente-se um novo homem e as duas agregadas, Ida e sua mãe Marie Buchner cantam uma canção de natal

\footnotetext{
${ }^{108} \mathrm{O}$ filho Robert costuma ir visitar a família no natal todos os anos. Mas o pai não aparecia há cerca de seis anos e aparece nesta noite sem avisar. Quanto a Wilhelm, vai à casa da família a pedido de sua noiva Ida e de sua mãe Marie Buchner, que em sua ingenuidade, acreditam que ele deva se reconciliar com toda a família nesta noite de natal.
} 
no cômodo ao lado, basta que alguns dos familiares riam de Ida, para que imediatamente tudo volte ao estado de antes e o ato termine entre gritos, choro e com o dr. Scholz passando mal:

Wilhelm (gritando) - Fique quieto, eu lhe digo!

Auguste (virando as costas para ele) Oh, bem, você apenas está apaixonado, só isso.

Wilhelm (agarrando Auguste asperamente pelo ombro) - Olhe aqui, mulher, eu -

Robert (pegando o braço de Wilhelm fala friamente, dizendo cada palavra distintamente) - Wilhelm, você vai fazer a mesma coisa de novo?

Wilhelm - Diabos!

Auguste - Tem algo a dizer? Você? Que levantou a mão contra o seu próprio pai?

Dr. Scholz (com a voz trêmula de raiva, num tom de absoluta autoridade) - Auguste! Saia da sala! Neste minuto!

Auguste - Bem, agora eu gostaria de saber...

Dr. Scholz - Você vai sair da sala neste exato minuto!

Frau Scholz. - Oh, meu Deus, por que não me leva destem undo?

(Em um tom meio choroso.) Auguste! Você está ouvindo?

Obedeça seu pai!

Robert - Por que, mãe? Ela não deveria fazer nada disso. Ela não é mais uma criança. Os tempos mudaram, por Deus, eles mudaram.

Dr. Scholz - Mas eu não mudei I haven't changed. Eu sou o dono desta casa. Eu vou mostrar isso a vocês.

Robert - Ridiculo!

Dr. Scholz (gritando) - La-drão e assas-ino! Eu deserdo você! Vou jogá-lo na sarjeta!

Robert - Isso é simplesmente cômico.

Dr. Scholz (conquistando uma explosão terrível de raiva e falando com calma e firmeza ominosos). -Você ou eu. Um de nós deixará a casa neste momento.

Robert - Eu, é claro, e ficarei muito feliz em faze-lo.

Frau Scholz (meio comandando, meio implorando) - Robert, você deve ficar.

Dr. Scholz: Ele vai.

Frau Scholz - Fritz! Escute-me! Ele é o único que em longos e longos anos nunca nos esqueceu, ele...

Dr. Scholz - Ele ou eu...

Frau Scholz - Desista desta vez, Fritz, por minha causa!

Dr. Scholz - Pare com isso! Ele ou eu.

Frau Scholz - Oh, vocês não tem nada a ver um com o outro. Até onde eu sei, tudo pode ser arranjado, mas...

Dr. Scholz - Muito bem, eu perdi. Perdi para você e seu bando. Você e seu bando me venceram definitivamente.

Wilhelm - Não vá, pai! Ou, se você for, deixe-me ir com você desta vez. 
Dr Scholz (retrocedendo involuntariamente, entre a reiva e o horror). Não me incomodem, vagabundos! (procurando às cegas a impressão causada) Ladrões e patifes, miseráveis vagabundos! Wilhelm (com uma explosão de indignação) Pai! E foi você quem nos fez assim. Não, não, pai, eu não quis dizer isso! Deixeme ir com você e eu ficarei com você. Deixe-me compensar tudo o que tenho... (tendo colocado a mão no braço do pai)

Dr. Scholz (como que paralisado de horror e desgosto) Solte-me! $\mathrm{Eu}$ lhes digo, os planos dos meus perseguidores fracassarão, eu sei. São essas pessoas as pessoas ponderosas? Um homem como eu, que é em parte culpado, mas de qualquer maneira é inteiramente e do começo ao fim curto e simples...

Wilhelm - Pai! Pai! Oh, meu querido pai! Tente se recolher onde está.

Dr. Scholz (balançando suavemente no ritmo das palavras) curto e simples, do começo ao fim...

Wilnelm (abraçando-o com um esforço instintivo para parar o movimento) - Tente, pai. Tente pensar!

Dr. Scholz (empurrando-o como uma criança pequena) - Oh, não me bata, Oh, não me puna!

Wilhelm - Pelo amor de Deus, pai!

Dr. Scholz - Não me bata! Não me bata de novo! (ele faz esforço convulsivos para se libertar dos braços de Wilhelm)

Wilhelm - Que minha mão apodreça, querido pai, que, você não deve acreditar, você não deve pensar...

(Dr. Scholz se solta ele mesmo e se afasta seguido por Wilhelm.)

Wilhelm - Acerte-me! Você me atingiu.

Dr. Scholz - Por favor, por favor. Socorro!

(Ida aparece à porta da sala lateral, pálida como a morte)

Wilhelm (pega seu pai, abraça-o novamente) - Oh, você me atingiu!

Dr. Scholz (nos braços de Wilhelm, desmorona numa cadeira)

$\mathrm{Eu}$, ah, ah! Penso...Está tudo acabado co-mi-go.

Wilhelm - Pai!!!!

(Frau Scholz e Auguste ficam aterrorizados nos braços um do outro, Robert, pálido como a morte, não se move, mas seu rosto tem uma expressão de invencível determinação.

Eis como termina este segundo ato. E não seria nenhum absurdo afirmar que é muito fácil cair em histeria neste momento da peça. Assim como em outros momentos do texto, as próprias rubricas indicam ações como "gritar" ou "chorar", que, se exageradas pelo ator, transformarão a peça num verdadeiro manicômio, distanciando-se da vivência verdadeira.

Ao tratar da atuação no Estúdio no que se refere a esta peça, Sulerjítski escreve em seu diário que: 
Quando o ator realmente vivencia algo, quando sua interpretação é uma "obra de arte", então por mais que o espectador seja intensamente agitado, não haverá histeria. Eu me recordo de Duse e inclusive de Grasso e outros grandes atores, como Shaliápin ou Nikita, ou atores do Teatro de Arte nos melhores papéis e momentos, e não consigo me lembrar e nem mesmo imaginar que a arte deles provocasse a histeria. Pelo contrário, entregando-se à sua arte, até as pessoas com os nervos desconcertados e propensas à histeria vão tranquilizar a alma e alcançar a satisfação espiritual. Pode ser que chorem no espetáculo, mas estas lágrimas serão completamente diferentes: serão lágrimas serenas e discretas - não para o público - , lágrimas nobres, de enternecimento diante do bem e da beleza, lágrimas pelas infelicidades e o pesar dos homens; até mesmo, talvez, pelo próprio pesar, já que eu também sou um homem e assim como os outros, estou sujeito aos sofrimentos; lágrimas deste tipo, pois somos todos infelizes, pois a vida não é perfeita, pois somos fracos no bem, pois amamos pouco uns aos outros e etc, porque o verdadeiro talento, a verdadeira arte, fala apenas sobre isso. (SULERJÍTSKI, 1970, p.343) [Tradução nossa]

Esta anotação de diário demonstra uma grande preocupação com o espectador, que deve ser contagiado pelo ator, mas não de uma maneira negativa, ou seja, não por meio dos nervos, mas da alma.

De forma que ao olharmos uma cena como esta, poderíamos nos indagar o que levou o Estúdio a encenar esta peça. Por que afinal, levar mais brigas, gritos e intrigas para os palcos, quando o que se desejava no Estúdio era justamente o oposto? Quando se tratava sobretudo de aquecer os corações dos espectadores?

Uma leitura completa e atenta de "A festa da paz" responde a esta pergunta. Obviamente que esta peça traz consigo a tristeza e a desilusão por toda parte e que além disso está carregada de questões naturalistas bastante terríveis e aparentemente sem solução. Mas, ainda assim e da mesma forma que ocorre em "O naufrágio do Esperança”, há aqui resquícios de amor e de sonhos por dias melhores. No caso de "O naufrágio do Esperança" - do qual, a propósito, já falamos anteriormente - há uma cena em que esta questão é evidente. Trata-se do momento em que a viúva Kneirtje coloca no filho Barrend os brincos que haviam sido do pai, dizendo a ele que não se preocupe, que não é preciso ter medo (apesar de ela saber que muitos barcos do local são realmente "caixões flutuantes”) e que ela rezará por ele e pelo irmão, pois há esperança. Da mesma maneira, quando em "A festa da paz" vemos gritos, brigas ou lamentos dos personagens, não quer dizer que a vida seja apenas isso. Há também uma abertura para a luz, instantes em que é 
possível enxergar uma saída, como durante a conversa que Ida e Wilhelm tem próximo ao final da peça:

Ida (seu rosto está pálido, o jeito muito sério e ansioso. Ela anda suavemente até Wihelm, abraça-o e pressiona sua bochecha contra a dele) - Oh, Willy! Ouça: dias tristes vem e depois... Não é assim, Willy? Os dias brilhantes vêm outra vez. Você não deve se permitir ficar tão absurda e completamente esmagado. Wilhelm (balbuciando apaixonado) - Ida! Minha mais querida, doce, como eu poderia viver sem você? Sua voz, suas palavras, toda a sua doçura, suas mãos...

Ida - E quanto a mim? Você acha que eu quero viver sem você? Não, querido. Nós vamos colocar nossos braços em torno um do outro e não vamos nos larger. Vamos nos apertar, apertar e enquanto estivermos assim...

Wilhelm -Sim, sim, mas suponha que não possamos ficar assim? Ida - Oh, não diga isso!

Wilhelm - Eu só quero dizer, você nunca pode dizer isso, pois um de nós pode morrer...

Ida - Oh, mas somos jovens.

Wilhelm -Não faz diferença. Isso virá afinal. Tenho certeza de que não vou viver até a velhice.

Ida (calorosa) - Então eu vou abraçar você apaixonadamente, vou abraçar você bem de pertinho e vamos juntos. (HAUPTMANN, p.382)

Sempre há dois lados. E isso não só na encenação, como também e sobretudo em cada um dos personagens retratados. Leopold Sulerjítski sabia disso e durante os ensaios desta peça alertava seus alunos para que não criassem os personagens numa só tonalidade: que não pintassem o quadro sem enxergar seus matizes: "Não é porque eles brigam que são pessoas ruins, e porque se reconciliam que são bons na essência. Isso é o principal.” (SULERJÍTSKI, apud VAKTHANGOV, 1970,p.555) [Tradução nossa]. Isso facilmente recorda o que Stanislávski já dizia em suas anotações de 1908, isto é, que:

A paleta dos artistas iniciantes é pobre de tintas. Eles pintam todo o papel somente de um tom, sem sombras, brilhos, meiostons, modulações e transições. Pintam os trágicos e os vilões somente de cor preta e os jovens e alegres somente de cor clara. O primeiro é sempre sombrio e o segundo está sempre sorrindo. Se um artista plástico seguisse o mesmo exemplo, em vez de um quadro, ele deixaria uma grande mancha preta ou branca em que seria impossível distinguir os detalhes do quadro. (STANISLÁVSKI, in: VÁSSINA, E. e LABAKI, A., 2015, p.166) 
Leopold Sulerjítski dizia ainda sobre "A festa da paz”:

Cedam toda a cordialidade que está em seus corações, busquem os olhos e o apoio uns dos outros, animem-se ternamente entre si para revelar a alma. Com isso, e apenas com isso, vocês conduzirão os espectadores para si. Não é preciso ataques de histeria, joguem-nos fora, não se atraiam pelo efeito dos nervos. Vão ao coração. (SULERJÍTSKI, apud: VAKTHÁNGOV, 1970, p.555) [Tradução nossa]

Eis como novamente Leopold Sulerjítski se utilizava da arte como um meio de ensinar para a vida. De levar aos alunos aquele tipo de conhecimento que não ficaria apenas guardado em suas mentes, mas também em seus corações.

Leopold Sulerjítski amava seus alunos. Essa era uma das razões que fazia com que desejasse o desenvolvimento de todos não só como atores, mas sobretudo como seres humanos. Mikhail Tchekhov fala sobre este seu amor para com cada um dos alunos do Estúdio e aproveita narrar dois episódios marcantes e exemplares ocorridos consigo. $\mathrm{O}$ primeiro episódio, quando Tchekhov, na qualidade de recruta, teve de fazer exames médicos e Leopold Sulerjítski o acompanhou até o local. Saindo de lá, depois de quase um dia inteiro de espera para ser atendido, Tchekhov deparou-se com Leopold Sulerjítski, que, debaixo de chuva, ainda esperava por ele:

- Micha! - escutei uma voz baixinha e carinhosa.

Voltei-me. Diante de mim estava Sulerjítski, inteiramente molhado pela chuva torrencial. Pasmei. Leopold Antonovitch não se afastou do posto de recrutamento o dia inteiro e me esperou na multidão de parentes, que lamentavam seus filhos únicos... Mas quem era eu para ele, L. A. Sulerjítski? Um irmão? Um filho? Eu era nada mais do que um de seus alunos!!! (TCHEKOV, M. in: SULERJÍTSKI, 1970, p.700) [Tradução nossa]

O outro, refere-se ao desenho que ele mesmo fez no livro do Estúdio como resposta àquela que ficou conhecida posteriormente como a "Chanson triste" ${ }^{109} \mathrm{de}$ Sulerjítski:

Como todas as pessoas verdadeiramente boas, L.A. Sulerjítski gostava às vezes de parecer bravo, severo e até ameaçador. Ele

\footnotetext{
${ }^{109}$ Tradução já incluída neste trabalho no tópico 1.5 . Trata-se da longa carta em que Sulerjítski fala sobre a falta de ética dentro do estúdio.
} 
criou para o Estúdio um livro grosso no qual cada um de nós podia inserir seus pensamentos.

Um dia Leopold Antônovitch escreveu ele mesmo neste livro uma série de pensamentos sobre os trabalhadores, sobre sua vida difícil nas condições da época e por esse motivo, sobre a necessidade de relações atenciosas indispensáveis para com os trabalhadores do nosso teatro. Ao ler este artigo me entusiasmei com seu conteúdo mas, infelizmente, não achei nada melhor do que libertar a minha inspiração numa série de caricaturas com as quais ilustrei o artigo de L. A. Sulerjítski. À tarde, chegando ao estúdio, eu ouvi um grito tonitruante. L. A. Sulerjítski buscava o culpado pelas ilustrações e parecia pronto para estraçalhar a pessoa lá mesmo.

- Isto é um ultraje! - gritava ele de longe, aproximando-se de nós - Quem, quem se atreveu a fazer isso?!

$\mathrm{O}$ enfurecido L. A. Sulerjítski surgia nas portas, buscando a sua vítima.

- Quem fez isso? Fale exatamente agora! Quem?

- Fui eu... - respondi apavorado. Pausa.

- Bem, então que mal há nisso? - disse de repente terna e tranquilamente L. A. Sulerjítski. - Bem, desenharam! Bem, e o que há? Não há nada!

Leopold Antonovitch me abraçou, pronto para consolar, como se o culpado fosse ele, e eu o chamei para a responsabilidade. Tal era o espirito rancoroso de L. A. Sulerjítski. (Ibidem)

[Tradução nossa]

O ator Smychlaev (1970, p. 80) se lembra também do amor que Leopold Sulerjítski nutria pelos alunos do Estúdio. De como ele tratava amavelmente todas as pessoas, como as conhecia bem e acreditava que apesar das faltas e fraquezas, todas carregavam a verdadeira essência consigo. Sulerjítski sabia que seu papel era auxiliar os alunos a deixarem para trás suas fraquezas e que este seria um árduo trabalho. Mesmo assim não temia as pedras que surgiriam em meio ao caminho daí por diante e que ele teria de tirar, uma a uma. Apesar das dificuldades, ele auxiliava os alunos a deixarem para trás o seu mundo subterrâneo e irem para a luz.

O amor de Sulerjítski por seus alunos esteve todo o tempo profundamente vinculado com o desejo por educá-los. Esta foi uma das características centrais do seu trabalho no Estúdio e Konstantin Rudnítski não deixa de apontá-la, embora considere-a de certa forma exagerada. Isto porque a preocupação com a educação chegava a ultrapassar fronteiras e às vezes ganhava o primeiro plano, deixando a parte artística em segundo lugar. O aluno do Estúdio A. Popov fala sobre este aspecto: 
Assim como era para Stanislávski, para Sulerjítski a imagem moral e ética do homem ligava-se indissoluvelmente à sua imagem artística. Ele, portanto, educava os estudantes, no verdadeiro e profundo sentido desta palavra. Odiava a grosseria e o quotidiano com todo o horror que lhe era próprio. Ele podia elevar um ato não ético de um estudante a um acontecimento do mais alto grau de significação, do qual, conforme lhe parecia, dependia o destino de todo o Estúdio. Assim foi também certa vez: um dos estudantes deu-se ao luxo de conversar grosseiramente com o nosso único camaroteiro. Sulerjítski cancelou o ensaio, reuniu todo o elenco e o dedicou o dia inteiro à análise deste triste incidente. (POPOV, apud POLIAKOVA, 1970, p.82) [Tradução nossa]

Márkov relembra também o papel que a educação ocupava na vida do diretorpedagogo Leopold Sulerjítski dentro do Estúdio. Mas o aspecto que Markov enfatiza é o da questão ética dentro do estúdio. O teatrólogo russo analisa o fato de Leopold Sulerjítski utilizar-se do Estúdio e do Sistema para educar os alunos para a vida.

Sulerjítski queria desvendar a origem do trabalho criativo, queria encontrar a semente do trabalho criativo puro, porque ele mesmo era profundamente puro. No "Sistema" muito se falava sobre a fé do ator no significado e no realismo daquilo que ele fazia em cena. Sulerjítski ensinava os atores que se juntavam ao Primeiro Estúdio a acreditar, mas propagava esta fé fora dos limites do ensinamento essencialmente cênico: ele ensinava a acreditar na vida. Por isso Sulerjítski preferia o trabalho de direçãopedagógica com a composição espontânea do espetáculo. Ele tratava os atores com carinho e atenção. Este homem foi completamente puro e por isso, sincero na expressão de seus pontos de vista e impressões. (MÁRKOV, 1974,, p.358) [Tradução nossa]

Dada a relevância do papel pedagógico apresentado por Leopold Sulerjítski no decorrer de sua vida artística, realizou-se uma conferência na Rússia entre os dia 26 e 30 de novembro de 2012. Nesta conferência, o papel de Leopold Sulerjítski foi apontado por mais de uma vez, gerando a posterior publicação do livro Pedagoguika Isskustvo, em sua memória.

Um destes artigos deve necessariamente ser citado neste trabalho, pois explicita justamente a questão que serviu de mote para abrir este capítulo: o fato de Leopold Sulerjítski ter seu nome de certa forma escondido no que diz respeito a esfera teatral - se o compararmos a nomes de outros encenadores muito mais famosos do que ele, por exemplo. 
Neste artigo, diz o artista Avangard Nikoláevitch Leóntiev:

Pelo fato de Meyerhold e Vakthángov terem sido preferencialmente diretores, criando teatros, seus nomes são mais conhecidos do que o nome de Sulerjítski. Sulerjítski está nas sombras e isto é injusto. Pois este homem arrebatou muitos com uma paixão ardente e calorosa pelo trabalho coletivo . Foi ele precisamente quem Stanislávski encarregou de dirigir o Primeiro Estúdio do TAM; foi ele o encarregado de colocar em prática o seu Sistema de educação do ator e criação da imagem. Graças a este Sistema ficou conhecido em todo o mundo o nome de Stanislávski e do Teatro de arte. (...) Sulerjítski foi capaz de organizar uma família, criá-la e ser a sua cabeça, o seu centro, o centro espiritual, o pai, o defensor. E é muito bom que pessoas se reúnam e conversem sobre a herança de Sulerjítski. Isto é verdadeiramente uma Homenagem a ele! (LEÓNTIEV, 2013, p.37-9)

Além desta afirmação de sua importância atual, vale a pena olharmos também para o que diz o premiado artista russo Adolf Shapiro neste mesmo livro. Pois de acordo com ele, o papel central de Leopold Sulerjítski na pedagogia residiu precisamente no fato de este homem ter sido um dos primeiros, ao lado de Konstantin Stanislávski, a mudar o vetor que havia no teatro, ou seja, o foco sempre sobre o espectador. Com a criação do Estúdio, o vetor se movia do espectador para o ator, que é justamente quem se encontra por trás do trabalho criador. O teatro passou a ser visto como um espaço onde é possível conhecer-se a si mesmo, desenvolver as várias individualidades e formar novos cidadãos.

Hoje em dia o teatro é este espaço. Onde, embora o espectador seja importante e muito! - , já que "O acontecimento artístico se completa quando o contemplador elabora a sua compreensão da obra. Na relação dos três elementos - autor, contemplador e obra - reside o evento estético" (DESGRANGES, 2006, p.28), agora o ator ocupa papel essencial também. E não são poucos os casos em que o teatro é utilizado como ferramenta transformadora do ser humano em nosso tempo. ${ }^{110}$ Tal característica transformadora, bem como este olhar para a educação do ator e seu aperfeiçoamento, estão revelados resumidamente e com todas as letras em uma página de caderno escrita por Serafima

\footnotetext{
${ }^{110}$ Cite-se aqui como exemplo disso os artigos de Teatro-ensino teoria e prática (2004). Neste livro, professores universitários falam sobre suas experiências com pedagogia teatral. E enquanto o prof. Dr. Narciso Telles, por exemplo, afirma que "A compreensão da importância da arte na formação do indivíduo emancipado, como um instrumento capaz e atuar criticamente em prol da transformação, está presente em todas as ações pedagógicas-teatrais desenvolvidas em comunidades brasileiras"(p.22), o prof. Dr. Renan Tavares, diz que na França "O trabalho conjunto, em parceria, entre educadores e artistas de teatro envolve todos na reflexão e na prática do fazer teatral."
} 
Bírman em 5 de novembro de 1914 e conservada atualmente no RGALI, em Moscou. Neste arquivo, que consta de anotação feita durante uma aula de Leopold Sulerjítski, Serafima Bírman escreve:

5 XI. 1914 Primeiro ano. Com L. A. Sulerjítski

O objetivo da arte é contagiar as outras pessoas com os próprios sentimentos. A qualidade de um talento é ver mais do que os outros. $\mathrm{O}$ ator, premiado com talento, ainda não pode agir sobre o público se não possuir a forma na qual é preciso colocar o conteúdo. O ator deve ser educado ética e esteticamente. A atuação (a nossa) exige grande atenção para com a nossa individualidade!

O Estúdio favorece o estudo daquelas condições junto às quais se manifesta a alma inconscientemente. O estado inconsciente é o ideal desejado em cada trabalho criativo. E para isso, assim como na música é preciso saber a técnica, nós precisamos saber tudo o que ajuda ou atrapalha na manifestação do inconsciente. Estes estudos são para entender em que consiste o trabalho criativo. Começamos a entender com a razão e agora já é indispensável entendermos com o sentimento.

O objetivo do primeiro curso é: do consciente passar para o inconsciente. (BÍRMAN, arquivo do RGALI) [grifo do autor, Tradução nossa]

Se como é dito no prefácio do livro Pedagóguika Isskustvo, "Os grandes professores são aqueles de quem lembramos por toda a vida, que se distinguem pelo fato de ensinar durante toda a vida com talento e prazer e contagiam com esta paixão os seus alunos" (NIKÍTINA, 2013, p.7), está mais do que provado o quanto Leopold Sulerjítski exerceu papel fundamental enquanto pedagogo. Pois ele não apenas ensinou com prazer e talento, como também contagiou todos os que estavam ao seu redor; não só foi lembrado por toda a vida por seus alunos, como inclusive por Konstantin Stanislávski que havia sido seu mestre e que em 1938 disse a Olga Sulerjítskaia após cruzar com ela numa rua: “ Não há um dia, nenhum dia, em que eu não lembre de Súler... Acredite que é assim. Eu digo a verdade.” [Tradução nossa]

\subsection{Navio de partida}

Uma das principais lições que Leopold Sulerjítski deixou a seus alunos foi a ideia de encarar a arte como uma forma de promover o amor e a união entre os homens. Em sua 
concepção, o teatro deveria ser este espaço de fraternidade e aprendizado, uma espécie de casa para a qual cada um deve levar o que há de melhor dentro de si.

A noção de união sempre esteve por trás de seu trabalho realizado no teatro. Para Leopold Sulerjítski, era preciso que os alunos se auxiliassem uns aos outros, que trabalhassem em equipe. Em seu caderno de anotações encontrado entre os arquivos do Teatro de Arte de Moscou está presente esta ideia quando lemos que: "A qualquer momento de seu trabalho o diretor vai pedir ajuda, que sem falta se norteará exclusivamente pelos objetivos ou tarefas de seu diretor, ajudando-o a atingir aquilo que ele deseja no tocante ao resultado e o sentido da peça e sua forma." (SULERJÍTSKI, arquivo do TAM) [Tradução nossa] [grifo nosso]

Mas este desejo de que os alunos formassem um grupo e que se apoiassem para conquistar um bom resultado, trabalhando não apenas para si mesmos, como também para os outros, servindo, auxiliando e orientando-se entre si, não foi apenas uma anotação deixada por Sulerjítski em seu caderno. Aliando-se aos ideais de amor, trabalho e respeito pelo ser humano, tal desejo por união acompanhou Leopold Sulerjítski por toda a vida, servindo de impulso não apenas para cada uma das atividades que ele realizou no Primeiro Estúdio, como também para a aventura que ele e seus alunos viveram nas terras de Evpatória.

As terras de Evpatória, localizadas na costa do Mar Negro, na Crimeia, serviram de pano de fundo para o episódio em que finalmente Leopold Sulerjítski juntou os dois caminhos que dividiam a sua alma desde o início de seu trabalho no TAM: a terra e a arte. Konstantin Stanislávski (1970, p. 549) se lembra de como um dos grandes sonhos de Sulerjítski "era a sua própria terra, que ele queria lavrar com as próprias mãos e irrigar ele mesmo depois. Cada homem deve se alimentar e trabalhar para si com as próprias mãos. Não deve haver nem criado e nem senhor." [Tradução nossa].

E se de repente era possível tomar para si este sonho antigo e uni-lo à sua vida na arte, porque não o fazer?

Leopold Sulerjítski via no campo e no contato com a natureza uma possibilidade inigualável de comunhão entre os alunos e acreditou que esta seria a melhor forma de trazer a união para dentro do Estúdio. De acordo com as recordações de Stanislávski, Sulerjítski já havia falado em uma de suas conversas sobre o desejo de trabalhar com os alunos no campo. Ele via nisso uma necessidade, uma forma de aprender a conviver em comunhão: 
Precisamos viver todos juntos na natureza. Só então nos conheceremos verdadeiramente uns aos outros, nos uniremos em família e amaremos a todos. Compremos juntos uma terra, vamos ará-la, vamos nós mesmos construir casas para o que der e vier. No inverno, a arte; no verão, a natureza e a terra (SULERJÍTSKI apud STANISLÁVSKI, 1970, p. 551)

[Tradução nossa].

Acreditando fortemente neste ideal de Sulerjítski, Stanislávski comprou para o Estúdio algumas terras em Evpatória e juntos, com as próprias mãos, alunos e diretores construíram lá prédios de natureza social, uma cavalariça, estábulos e outros locais que julgaram necessários para a realização de suas atividades artísticas. Durante cerca de três anos os alunos iam para Evpatória durante o verão, onde, encabeçados por Sulerjítski, trabalhavam intensivamente neste seu projeto de unir arte e vida numa espécie de amálgama.

Esta noção da arte e vida como uma coisa só é abordada no artigo "O teatro russo à luz dos problemas de recepção: abordagem semiótica" (2013) escrito por Elena Vássina. $\mathrm{O}$ artigo traz à luz uma questão de personalidade coletiva, fundamental para o estudioso russo de semiótica Iúri Lótman (1922-1993). Para Lótman, o teatro ocupa um espaço central na cultura, sendo capaz de realmente unir as pessoas. Neste sentido, embora os espectadores inicialmente não formem um verdadeiro conjunto e sejam apenas uma reunião casual de indivíduos dentro de um espaço, basta o espetáculo começar para que todos se unam em uma personalidade coletiva.

Este fator da coletividade, o qual lembra imediatamente o "milagre" ocorrido na encenação de $O$ grilo na lareira, quando toda a plateia se uniu para vivenciar o que se passava em cena, foi também uma das características centrais do Teatro de Arte de Moscou. Desde o início o TAM se preocupava em transformar esta "reunião casual de indivíduos" numa personalidade realmente coletiva. Exemplo disso foi a peça Um inimigo do povo, encenada pelo TAM em 19 de fevereiro de 1901 e que por ter estreado justamente no dia de massacre de alguns estudantes pela polícia, criou um vínculo profundo com a plateia, transformando-se numa verdadeira manifestação política, à qual o público reagia coletivamente.

A noção apresentada por Iúri Lótman ganha espaço também em Evpatória. Mas no caso desta experiência artística realizada pelo Estúdio, o "conceito de TEATROCASA, entidade que reúne palco e plateia como um grupo de 'crentes' na mesma ideia estética, 
social e política que possui o código comum da comunicação" (VÁSSINA, 2013, p.42), vai além da união entre público e plateia. Embora a encenação teatral fizesse parte dos planos para o futuro do Primeiro Estúdio em Evpatória, visava-se aqui inicialmente a união dos artistas entre si e com a natureza, isto é, a total fusão da vida com a arte. E com isso, consequentemente, a ideia de arte enquanto comunhão dos homens, já levantada por Lev Tolstói em $O$ que é Arte?

Ao recordar-se dos verões em Evpatória e da datcha comprada por Stanislávski, a qual posteriormente recebeu o nome de "Robinson", a atriz do Estúdio Serafima Bírman (1970, p.619) fala sobre a calma admirável que havia no local, sobre o brilho do lago de lá, sobre o calor e a areia, e por fim, sobre como cada um destes fatores os afastava da vida citadina. Aqui, neste lugar onde a vida era arte e a arte era vida, alunos e professores podiam se libertar das vestes habituais e da imagem que tinham quando estavam na cidade. O próprio Leopold Sulerjítski, por usar seu mocassin e o chapéu dos tempos da transferência dos dukhobors para o Canadá, é comparado por Birman a um herói dos romances de aventura de Julio Verne.

Até que Sulerjítski, já bastante debilitado, adoeceu definitivamente e esta sua aventura, uma das últimas de sua vida, foi ficando cada vez mais distante, sendo levada para longe de seus olhos, como um navio que se perde no horizonte. Em 1909, o diretor já havia sido diagnosticado com nefrite ${ }^{111}$. Mas piorava agora a cada dia e por conta de uma série de outros problemas dentro do Estúdio, desanimava cada vez mais. Ele, que havia passado a vida acreditando na necessidade de dar a todos o que havia de melhor em si, isto é, toda a pureza e honestidade possíveis, agora pensava no quão era difícil para um homem reeducar o mundo apenas com sua própria bondade. E com isso a harmonia se esvaia gradualmente de sua alma.

Elena Poliakova fala sobre este momento conflitante, quando Sulerjítski desanima e só o que o salva é este pequeno mundo à parte criado em Evpatória

Durante o verão, em Evpatória, novamente reunia-se com os velhos amigos e estudantes. Lá outra vez revelava-se tudo o que há de melhor nas pessoas, lá todos eram amigáveis e alegres e o alegre Súler transformava cada trabalho quotidiano em festa. Apesar da doença cruel prolongada, havia a alegria de viver dentro dele. Mas cada vez mais frequentemente esta alegria se apagava, fragilizando a vida, que não ía inteiramente como ele havia sonhado. (POLIAKOVA, 1970, p.91) [Tradução nossa]

\footnotetext{
111 Doença inflamatória dos rins.
} 
Mas, embora os momentos vividos em Evpatória e em contato com a natureza fossem capazes de alegrá-lo outra vez, tanto a doença, quanto os problemas na administração e a falta de união dos estudantes o afetavam profundamente.

É justamente nesta época que ele passa a se sentir mais desnecessário ao Estúdio, decide partir do cargo de administrador e escreve a Konstantin Stanislávski uma carta na qual fala sobre esta sua decisão. Nesta carta, escrita em 27 de dezembro de 1915 (7 de janeiro de 1916) e onde ele diz que o Estúdio já é uma grande instituição, está formado e não precisa mais de seu serviço de organizador, Sulerjítski aproveita para refletir sobre todo o seu sonho, a sua ideia do teatro:

...Eu sonhei com um teatro onde toda a arte, repleta de todas as verdades, aquecesse as pessoas com seu amor pelo humano, para que a fé no homem se mantivesse nesse nosso tempo assustador e cruel, para que esta mesma troupe, constituída de pessoas que vivem cordialmente e amigavelmente no trabalho e em total liberdade - durante o inverno se entregando à arte $\mathrm{e}$ durante o verão vivendo alegremente na beira do mar onde tudo foi criado com o seu trabalho -, suscitasse nas pessoas admiração pela própria vida e pela arte.

No segundo ano, quando todos os membros do estúdio se mordiam até a hediondez, quando tudo era uma completa podridão, eu enfraqueci e quis renunciar. Passei noites em claro no estúdio, temendo sair de lá não apenas de dia, como também à noite. Mas, reunindo todas as forças, eu fui adiante. E estava certo. Era melhor prevalecer e logo chegou o terceiro ano, cheio de alegrias e entusiasmo.

Todos se reconciliaram, acreditavam uns nos outros, e eu via por mim mesmo como as almas cresciam, como "O grilo" brilhava, como a vida amadurecia por si só nesta sonhada direção, como também a sala de espetáculos respirava enternecida pela alegria com que resplandecia a juventude. Começou o verão, e parte dos jovens foi para a terra em Evpatória. Comprou-se o inventário, nós mesmos construímos barracas, tomamos conta de cavalos comuns, carregamos tijolos, almoçávamos todos juntos.... Tudo isso ainda são apenas alusões, pedacinhos da vida e não as devidas tomadas de consciência, mas inclusive nestes rascunhos há muito de felicidade, alegria, pureza e liberdade.

O Teatro-estúdio está crescendo cada vez mais como teatro, já interpreta num grande palco de Petersburgo, a instituição já se desenvolve, cresce de tamanho, abre mais e mais espaço e ocupa cada vez mais lugares no público e na imprensa. Inevitavelmente se desenvolve cada vez mais o lado administrativo-econômico com seus trabalhos. E aí está....

Eis que teve início meu grande erro...

Estes trabalhos sempre são os mais desagradáveis, mas, por outro lado, eles dão sempre uma posição a quem com eles se 
ocupa. Involuntariamente cria-se a impressão de que as pessoas que se ocupam com isso, encabeçam os trabalhos; elas involuntariamente se sentem as donas do trabalho, inevitavelmente se estragam e se afastam do objetivo principal e do núcleo principal do estúdio, dos companheiros, juntandose em um certo órgão de poder, realizam já não uma vontade geral, mas apenas a sua própria, estreitando e rebaixando cada vez mais os objetivos e organizando já não aquilo que tinham em vista quando foram designadas, mas aquilo que é mais prático, a construção que é mais facilmente realizável. Qualquer sonho ou utopia se afasta e faz-se o "trabalho", bem ou mal - e é preciso avaliar atentamente para dizer para onde isso leva - , mas já não há sonhos. Todo o estúdio já não está vivendo uma vida coletiva. Estes três ou quatro homens conduzem o trabalho de forma completamente independente, todos os demais não participam absolutamente disto, não sabem nada daquilo que é feito e nem estão interessados em saber.

Este foi o meu grande erro: eu deveria ter sido mais insistente para que todos - todo o estúdio -, participasse da gestão. Teria havido muito barulho e discussões mas teríamos forjado algo, ou seja, o estúdio.

Quando eu vi meu próprio erro era tarde: já não posso influenciar estas pessoas.

Tendo entendido isso, me decidi pela possibilidade de equilibrar a composição do conselho, dando mais peso ao lado do idealismo, visto que ali o lado "do trabalho" era extraordinariamente forte e, portanto, perigoso, no sentido do enfraquecimento dos objetivos. Para isso eu acrescentei ao conselho: Soloviova, Fiódorova, Bírman e Bondyrev.

Em seguida eu quis me afastar completamente a tempo e me convenci de que a correção era um erro, que eles estão se formando, que os "homens de negócios" - a quem eu dou meu muito obrigado pelo trabalho - sob a influência de colegas tais como Soloviova, Fedorov e Birman, se tornarão menos interesseiros e se transformarão juntamente com aqueles que se sentem os "tais" donos do estúdio, visto que eu coloquei condições sine qua non, para que o conselho resolvesse o assunto em conjunto.

Aliás, esta consciência de si como "donos" influenciou alguns perigosamente; eu sabia que isso influenciava desse jeito, mas deixei escapar novamente e é muito difícil consertar isso.

Pois bem, eu acreditei que desta maneira era possível corrigir meu erro. Exatamente nesta época o senhor sentiu que o estúdio ia de mal a pior, me pediu que eu compreendesse que sou o administrador, que o estúdio confia em mim e em nenhum outro mais, que eu devo permanecer em meu posto firmemente, que devo recorrer à sua ajuda como a um companheiro mais velho, que devo recorrer à sua autoridade. Foi difícil para mim voltar atrás, mas infelizmente eu mesmo vi que temporariamente devo voltar atrás, pois o culpado sou eu mesmo.

Mas quando eu tentei voltar à situação precedente, isso já foi impossível, para isso seria preciso então lutar com este grupo. Esta luta, como todas as outras, é cheia de todos os sentimentos maus e pesados, eu não tenho forças suficientes para isso e o 
principal, é muito difícil moralmente. Mesmo por um objetivo tão belo não consigo encontrar as forças dentro de mim. Eu confessaria meu próprio erro: não soube organizar todo o estúdio. Se não fosse este erro, então...

Mas assim fala aquele que não pode.

Pelo segundo ano eu vejo como tive fé em uma "utopia". Vejo isso com meus próprios olhos.

Mas aí está o erro e o trabalho começou. Eu pude admirar a bela juventude, mas não consegui conduzi-la, e por causa de apenas dois ou três pus a perder muito na vida, deixando-os em situação difícil, largando-os sozinhos em situações tentadoras e perigosas, sem o auxílio de um homem mais experiente. Pudesse dizer que eles não são pequenos. Sim, mas com efeito eu os conduzi por três anos e eles eram.

Fiquei alegre e me entusiasmei com o sucesso cedo demais: meu erro eterno em tudo. Me custou ver os esboços, os rascunhos da realização da utopia no terceiro ano, quando tudo resplandecia, tanto aqui quanto em Evpatoria, e eu então abri a boca e me maravilhei, em vez de redobrar a atenção e o trabalho.

Eu saro apenas quando o material é excepcional e chega por si mesmo, como, por exemplo, os dukhobors.

Me vejo forçado a reconhecer que não consegui realizar meus sonhos. Aí está o fim. Não me interessa absolutamente o sucesso aparente do meu trabalho - o sucesso dos espetáculos e as casas cheias, que Deus os abençoe - não é isso o que me preocupa ou me inspira, mas a troupe-fraternidade, o teatrooração e o atorsacerdote. Tendo me faltado isso, devo partir. É doloroso que eu não tenha conseguido fazê-lo. Eu desanimei, desanimei demais. Não me prenda. Se eu não pude fazer isso, então não tem importância, vai dar na mesma, esta é e será a lei da vida humana. Acredito profunda e inteiramente nisso, que será assim cedo ou tarde, mas será; este sonho vive e viverá em cada homem. Talvez eu veja ainda mais, embora seja pouco provável. Mas isso já é outra coisa; eu preciso servir de outro modo: não dar início às tarefas, que não condizem com as minhas forças, mas servir tal como determinam as minhas forças.

Compreenda agora, Konstantin Sergueevitch, que eu não posso ser administrador do estúdio. Ser diretor de teatro não é inteiramente do meu feitio....

Compreenda, Konstantin Sergueevitch, que agora, quando vejo o que não consigo fazer neste trabalho, que é impossível servir como administrador neste trabalho, onde entreguei toda a minha alma e coração, isso é muito, é demais para mim. Liberteme: quando eu descobrir como poderei servir à minha fé, irei trabalhar. Por mais que eu esteja fraco e doente, ainda não decai tanto a ponto de trabalhar apenas por "um pedaço de pão". Chegará precisamente esta hora, é se obrigado a aceitá-la, tal como a morte, mas apesar de tudo, quanto mais longe estiver, tanto melhor....(SULERJÍTSKI, 1970, p.381-383) [Grifo nosso, Tradução nossa] 
Esta carta reflete não apenas o Leopold Sulerjítski doente, desgastado e triste diante dos problemas que invadiam o Estúdio, mas principalmente o homem sonhador, que apesar de toda a situação vivida e embora estivesse fraco para lutar, ainda via sentido na luta pelo verdadeiro ator-sacerdote, pelo teatro que é vida, pela vida que é união.

A questão de o Estúdio estar passando por uma fase complicada neste momento é também notada por Konstantin Stanislávski na mesma época e está posta em um documento conservado atualmente no Museu do Teatro de Arte de Moscou sob o título de “Apelo de Konstantin Stanislávski ao estúdio". Neste documento, escrito à mão em 11 de novembro de 1915 consta o seguinte:

Quando o Estúdio começou, parecia aos alunos verem um oásis cultural: esta instituição deveria trazer a característica de uma casa particular, caracterizar-se pela simplicidade, pelo asseio, a modéstia e a dignidade. Nós temos poucas instituições assim: a Galeria Tretiakov, as clínicas e o Teatro de Arte. É impossível viver sem tais oásis. Particularmente em tempos de guerra e depois deles, porquanto desperta-se a fera que há no homem. E nestes tempos terríveis não há pessoas mais felizes em todo o mundo do que aquelas que participam de um trabalho cultural tão sincero.

Mas para isso é preciso um idealismo verdadeiro, visto que apenas o idealismo é nossa justificação diante da sociedade. Se não há idealismo, o pior ofício é o ofício do ator. Este foi o sonho. (STANISLÁVSKI, Arquivo do Museu do TAM.)

[Tradução nossa]

Este documento está dividido em duas partes, sendo "A ideia do Estúdio" a primeira das duas, a qual acabamos de ler. Na segunda parte, "A atual situação do Estúdio", Stanislávski fala sobre como as coisas não se deram exatamente conforme o planejado e como precisamente nesta época, “Ao entrar no estúdio você vê algumas situações triviais e escuta e bisbilhotices na antessala. Mas adiante você se depara com a falta de ordem da economia de meia tigela. O ambiente completo não presta para a arte" (STANISLÁVSKI, 1915, arquivo do Museu do TAM) [Tradução nossa]

A partir daí, Stanislávski lança um apelo a seus alunos. Para que mudem o comportamento e não se preocupem apenas em saber a terminologia do Sistema, que eles já sabem. Que eles, ao contrário do que vem fazendo, se preocupem com a verdadeira arte, com o sentido mais profundo do estúdio, pois seu comportamento no momento não levará a lugar algum: “Assim, o cantor que sabe a anatomia da canção pensa que ele é um 
artista; assim, o mau sacerdote pensa mais sobre a cerimônia do que sobre Deus; assim o uniforme substitui o interior e a moda substitui o gosto." (Ibidem)

Toda esta questão do Estúdio estar passando por problemas deste tipo não quer dizer que o projeto de Konstantin Stanislávski e Leopold Sulerjítski tenha falhado. De forma alguma. Estes problemas, muito pelo contrário, foram como uma das várias tempestades por que passa o universo da arte de vez em quando. Destas que é preciso enfrentar para permanecer com vida e em meio às quais deve-se batalhar para manter a calma e não deixar que o navio afunde ou perca o seu rumo.

Foi o que ocorreu no Primeiro Estúdio, que não se deixou afundar diante desta situação. Ele não apenas continuou a viver, como também deu origem posteriormente ao Segundo Estúdio do TAM, do qual Evgueni Vakthangov foi o responsável; ele não apenas seguiu sua rota, como também viu em seus frutos Richard Boleslávski e Mikhail Tchekhov, a continuidade das ideias e do Sistema de Konstantin Stanislávski , e dos princípios de amor, trabalho e união propagados por Leopold Sulerjítski. Sim, porque apesar de Sulerjítski se sentir culpado pelo vento forte que soprava naquele instante, ele havia sido um verdadeiro marinheiro todo este tempo. E continuava a ser, ainda encontrando forças para incutir ideais nobres em seus alunos e auxiliá-los em seu crescimento pessoal e profissional, como mostra esta carta, escrita em 9 de novembro de 1915 para os alunos que estavam em São Petersburgo:

Caros, queridos jovens!

Agradeço por sua atenção, por seu amor, por seu cuidado e o trabalho particular com este álbum que vocês tão cuidadosamente fizeram e me enviaram, e que me alegrou; e um agradecimento maior por aquilo que vocês são, pela gramática da "essência" que há em vocês.

Pelo fato de vocês saberem amar tão leal e ternamente aquilo que lhes parece belo, puro e sublime, por vocês saberem preservar em si a juventude, o que é tão raro hoje em dia.

Se merecemos ou não esse amor e a fé de vocês, isso não importa. Mesmo se não merecermos, não é uma desgraça, não é este um engano terrível pois o amor sempre está correto, pois ele é por si só aquilo que sempre e em todo o lugar é a única necessidade, a única coisa sem a qual não há vida e sem a qual toda a existência de todas as criaturas seria um cruel e total absurdo. E por isso mesmo não temam os enganos que o amor sempre traz mais àquele que ama do que àquele que é amado. $\mathrm{E}$ quem entender isso sempre será feliz.

Lembrem-se de Dom Quixote e Dulcinéia (a propósito, por todos os meios, procurem ver Chaliápin em "Dom Quixote"). Eu escrevi desta forma, como se o nosso estúdio estivesse muito 
mal e já não valesse a pena o que ele significa, mas a questão é que eu mesmo estou demasiado próximo a ele e por isso não o estou julgando completamente. Assim como vocês eu amo nele aquilo que nele é bom.

Por enquanto até logo. Estou com pressa parra o ensaio, meu filho está inquieto e não tenho muito tempo.

Desculpem não chamá-los pelo nome e patronímico Eu lembro muito mal estas coisas; mas da alma e do que existe nelas eu me lembro sempre.

Tenham saúde e juventude e mais adiante acreditem precisamente apenas em si mesmos com tudo o que tem de bom e não mudem isso por nada.

Desculpem as sentenças, isso é pela velhice e pela doença. Perdoem também a letra, eu acabei de me recuperar estou saindo do segundo dia completo e ainda estou fraco.

Seu L. Sulerjítski

(SULERJÍTSKI, 1970, p.507) [Tradução nossa]

Este marinheiro, apesar da doença e da fraqueza, encontrava forças para continuar sua viagem e erguer a bandeira do amor diante de seus alunos. Para falar sobre o trabalho e a felicidade diante das coisas mais simples, como quando escreveu a Stanislávski em meio a uma carta datada de 25 de abril de 1916 : "Ler o Evangelho, os pais santos e os sábios e muito simplesmente trabalhar, trabalhar simplesmente com as mãos, purificar a alma, jejuar e pensar, pensar sempre, encher-se e depois pôr-se a cantar. Que felicidade!"

Até que no outono de 1916 o navio de Leopold Sulerjítski partiu definitivamente deste mar de sonhos e inquietudes que é o nosso mundo. Nesta época Sulerjítski esteve mais vezes no hospital do que em sua própria casa. Seu organismo já não podia mais resistir porque os ataques de uremia atormentavam-no e nem mesmo os doutores eram capazes de ajudá-lo. Assim, ele que estivera se tratando em Evpatória, teve de voltar para Moscou, onde permaneceu até a morte, aos 44 anos.

Nos últimos dias, já não conseguia falar. Mas através de um simples gesto como segurar um livro, ainda era capaz de comunicar seu amor pela arte.

Ele caiu de cama para o vagaroso falecimento. Deitado, ele não soltava das mãos uma barata edição de Dickens, e agarrava-se a ela precisamente como a um fiapinho da arte. (...) Mas o sentimento criador e os pensamentos já não obedeciam Suler e ele impotente, segurava o livro nas mãos, não encontrando palavras para expressar seus devaneios poéticos. Finalmente o livro amarrotado escapou de suas mãos fracas e... para sempre rompeuse a ligação com a arte. (STANISLÁVSKI, 1970, p.552) [Tradução nossa]. 


\subsection{Finalmente a luz!}

Konstantin Stanislavski se apresenta outra vez. Fala sobre suas novas ideias. Repete a palavra "Sistema" e parece incompreendido por todos. Os atores dão as costas a ele. E deixam o palco vazio, um a um.

Apenas um homem vestido com um blusão de marinheiro permanece ao seu lado.

Mas o palco está mal iluminado e eu não consigo ver seu rosto. Quem é este homem? Ele diz algo muito importante. Algo sobre coração e união.

Se adianta mais um pouco.

Finalmente a luz!

STANISLÁVSKI: ${ }^{112}$ Senhor, leve consigo a alma do finado, do nosso querido, inesquecível e bom Súler, pois ele sabia amar, pois na vida em meio à sedução, à vileza, ao autoextermínio brutal ele conservou em si misericórdia, a qual limpidamente ditou-lhe antes da morte estas claras palavras de amor...

VOZ DE SULERJÍTSKI: ${ }^{113}$ (sereno) Meu Deus, quão amargamente, quão ardente e sinceramente chorei hoje a manhã toda. Chorei tanto que o travesseiro e as mãos ficaram húmidos de lágrimas. Por que motivo? Porque há crianças , muitas crianças nas ruas, magrinhas como pauzinhos e com mãos imundas; porque à noite na grande praça, sob frios lampiões elétricos, elas correm para os bondes e vendem jornal por um "Copeque" e desentendem-se e xingam-se detestavelmente; porque a polícia as expulsa e isso me dá pena; porque há uma multidão sem fim de recém nascidos em hospitais, com carinhas magrinhas, enrugadas e decrépitas, com dedinhos pálidos que mal se se mexem, deitados em filas, solitários, em mesas, identificados por números e que avidamente caçam o ar, gritam famintos até não poder mais, acalmam-se e definham, e morrem, fitando o vazio, procurando pelo amor neste vazio com os olhos agonizantes e tristes com isso, morrem solitários em fraldas molhadas e frias.

Porque as criadas de lá já não sentem este mar de sofrimentos no qual enxaguam a roupa, e andam, não como se estivessem em um templo, mas numa fábrica. Porque, porque há tanto sofrimento por toda parte, que eu me sinto culpado por isso, pela maior parte dos

\footnotetext{
${ }^{112} \mathrm{O}$ trecho citado a seguir é retirado das últimas linhas que compõem as recordações de Stanislávski sobre Leopold Sulerjítski.

${ }^{113}$ Cito a seguir as claras e límpidas palavras de amor a que se refere Stanislávski. Trata-se de uma página de diário de Leopold Sulerjítski que Stanislávski cita como forma de concluir suas recordações. Esta página é datada de 12 de setembro de 1913.
} 
sofrimentos, porque eu sei disso e não faço nada para pôr um fim, porque eu amo a todos e sou capaz de chorar por horas, e o principal, choro porque há pouco amor em mim para todos eles, tão pouco amor, que posso viver entre tudo isso e me ocupar com as minhas coisas, tão pouca fé e conhecimento, que não consigo "fazer" nada por eles e não faço.

Senhor, dê-me fé ou dê-me um coração tão grande que me guie para onde for preciso, e me ensine a viver conforme for preciso!

Senhor, me dê isto! Se o senhor existir. [Tradução nossa]

(Entram 3 atores)

BIRMAN: O seu amor pelo estúdio, aliás, por nós foi absorvido por todos... ${ }^{114}$ MIKHAIL TCHEKHOV: (...) Súler se zangava, gritava, ameaçava, mas os gestos que ele revelava diziam: "Vocês são meus queridos, eu os amo, não temam!"115

VAKTHÂNGOV: Você nos deixou, nosso belo e nobre professor. Por quantos dias seguidos escutamos a sua voz, ouvimos as suas simples e sábias palavras, vimos você aqui, nesta sala, nestas cadeiras, aqui, no palco. Cada palavra de nossos papéis, cada tema de nossas peças, cada passo nosso nos bastidores lembram você. Você não está entre nós, mas continua entre nós de forma exigente e insistente. ${ }^{116}$

Cai o pano.

\footnotetext{
114 BIRMAN, 1970, p.616

115 TCHEKHOV, 1970, p.605

${ }^{116}$ VAKTHÂNGOV, 1970, p.553
} 


\section{CONCLUSÃO}

Por mais de uma vez artigos escritos sobre Leopold Sulerjítski relembram a frase de $O$ pássaro azul que é dita quando Titil e Mitil encontram seus avós no país da saudade: “Os mortos dos quais lembramos vivem entre nós". Evguêni Vakthângov diz exatamente a mesma frase ao recordar-se de seu amigo e professor. Eu, por minha vez, repito-a neste trabalho. Mas não para fazer como os outros, senão apenas para reforçar esta ideia de que Leopold Sulerjítski vive entre nós cada vez que ouvimos o que tem a nos dizer.

Este trabalho de caráter inédito se baseou nos originais russos como forma de aprofundar o estudo de algumas das principais facetas deste grande mestre teatral e pedagógico do século XX. Temos agora, pela primeira vez em língua portuguesa, acesso a cartas, diários, ensaios e materiais dos arquivos conservados ainda hoje em Moscou. $\mathrm{O}$ que nos permite enxergarmos um pouco mais sobre quem foi este homem.

Neste sentido, é inegável a importância que teve a bolsa BEPE fornecida pela FAPESP de março a maio de 2016. Somente a partir da pesquisa realizada em Moscou, da pesquisa em arquivos e da conversa com especialistas da área é que foi possível o resultado aqui obtido.

Graças aos materiais traduzidos podemos compreender o papel desempenhado por Leopold Sulerjítski em sua época. Um papel significativo em todos os sentidos: quando acompanhou os dukhobors para o Canadá a pedido de Lev Tolstói, quando auxiliou Stanislávski na criação e no desenvolvimento de seu Sistema, quando ajudou cada um de seus alunos de alguma forma, sendo posteriormente lembrado por eles com muito carinho e afeição. Em suma, quando serviu aos outros de alguma maneira. Pois ele não apenas pedia que todos estivessem a serviço do próximo: ele mesmo estava sempre a serviço de quem quer que precisasse.

"Sede aquilo em que quereis transformar os outros. Que seja uma prédica o vosso ser, não as vossas palavras.", já dizia Henri-Fréderic-Amiel em seu Diário íntimo. É de crer que Sulerjítski, que lia Amiel, tenha ouvido bem esta lição. Pois foi exatamente este princípio, de ser algo primeiro para então conseguir transformar o próximo, que o guiou ao longo de sua vida.

Leopold Sulerjítski incutiu nos atores da época o ideal do serviço artístico e da missão moral do ator. Estabelecendo um compromisso ético tanto com o ofício quanto 
com os companheiros de trabalho, "deu a eles exatamente o que de principal exige um aluno do professor - deu-lhes um 'objetivo' profundo e natural para o trabalho criador: tal era o seu papel e tarefa no Estúdio.” (MÁRKOV, 1974, p.356)

Sim, ele foi este professor, que em cada uma de suas atividades revelou-se um idealista com objetivos morais e estéticos dos mais elevados, sempre em busca do aperfeiçoamento de seus alunos como seres humanos e da verdade e inspiração artísticas na simplicidade, no amor e na comunhão com a natureza. Mas antes de ser professor, foi aluno de mestres como Lev Tolstói e Konstantin Stanislávski, nos quais baseou muitas de suas visões de mundo, sem, no entanto, perder sua individualidade e suas próprias convicções. Pois um verdadeiro mestre não nasce do nada e nem se faz no vazio. Mas precisa de alguém em quem se inspirar. E, a partir daí, sabendo precisamente o que e como ensinar, servirá também ele de inspiração a outros. 


\section{REFERÊNCIAS BIBLIOGRÁFICAS}

SULERJÍTSKI, L. A. Povesti $i$ rasskazy. Staty $i$ zametki o teatre. Perepiska. Vspominania o L. A. Sulerjítskom. M: Isskustvo, 1970. 707 s. ${ }^{117}$

ARANHA, Maria Lúcia de Arruda. “Capítulo 28. Introdução à moral.” In: Filosofando: Introdução à filosofia/ Maria Lúcia de Arruda Aranha, Maria Elena Píres Martins. São Paulo: Moderna, 1986 . História da educação e da pedagogia: geral e Brasil.- 3ed. - Rev e ampl.

- São Paulo: Moderna, 2006

BAKTHIN, M. Questões de literatura e de estética. (A teoria do Romance) Trad. Aurora F. Bernardini et ali. 4 ed. São Paulo, UNESP: 1998

BASSÍNSKI, Pável. Tolstói: a fuga do paraíso. Trad. Klara Guriánova. São Paulo: Leya, 2013

BÁTCHÉLIS, Tatiana. "Stanislávski e Meyerhold”. In: CAVALIERE A., VASSINA, E. (orgs.) Teatro Russo - Literatura e Espetaculo. São Paulo : Ateliê Editorial , 2011.

BERNARDINI, Aurora Fornoni. As cartilhas do conde Liev Nikolaievitch Tolstói. In: Contos da nova cartilha. Primeiro livro de leitura. Cotia, SP: Ateliê Editorial, p. 11-23, 2005

BENJAMIN, Walter. “O narrador. Considerações sobre a obra de Nikolai Leskov”. In: Obras escolhidas. Magia e técnica. Arte e política. São Paulo. Brasiliense.

BERTHOLD, Margot. História Mundial do teatro. São Paulo: Perspectiva, 2004.

BIRMAN, S. Sudboi darovanie vstretchi. Moskva: Isskystvo, 1971 s.39-67 . Vospominanie. In: SULERJÍTSKI, L. A. Povesti i rasskazy. Staty i zametki o teatre. Perepiska. Vspominania o L. A. Sulerjítskom. M: Isskustvo, 1970. 707 s

\footnotetext{
117 Сулержицкий Л. А. Повести и рассказы. Статьи и заметки о театре. Переписка. Воспоминания о Л. А. Сулержицком / Общ. редакц. В. Я. Виленкина, сост., ред., ступит. ст. и коммент. Е. И. Поляковой. М.: Искусство, 1970. 707 с. Aqui encontram-se as cartas, os diários e as memórias de Olga Sulerjítskaia, Mikhail Tchekhov, Konstantin Stanislávski, Serafima Birman e as demais utilizadas no decorrer do trabalho, sinalizadas com o ano da edição, isto é, 1970.
} 
BOLESLÁVSKI, Richard. A arte do ator. As primeiras seis lições. Trad. e notas: J. Guinsburg. São Paulo: Perspectiva, 1992.

BOHM, Winfried. História da Pedagogia de Platão à atualidade. $3^{\mathrm{a}}$ ed. - Florianópolis: Conceito Editorial; CH. BECK WISSEN, 2010. 16 Op.

BULGAKOV, Valentin. L. A. Sulerjítski. In: O tolstom, Druzia i blizkie. Disponível em: http://az.lib.ru/b/bulgakow_w_f/text_0170.shtml

COURTNEY, Richard. "O teatro e a historia do pensamento educacional" In: Jogo, Teatro \&Pensamento. Sao Paulo: Perspectiva, 1980. pp.3-18.

DESGRANGES, Flavio. A pedagogia do teatro: provocação e dialogismo - São Paulo: Editora Hucitec; Edições Mandacaru, 2006

DICKENS, Charles The Cricket on the hearth. A fairy tale of home. http://www.ibiblio.org/ebooks/Dickens/Cricket/Dickens_Cricket.pdf

DIDEROT. Paradoxo sobre um o comediante. Tradução e notas de J. Guinsburg.

EFROS, N. Svertchok na petchi. Izdanie. A. E, 1918. 87s.

ERASSO, N. Os diários de juventude de Liev Tolstói. Tradução e questões sobre o gênero de diário. Dissertação de mestrado, orientador: Noé Silva. São Paulo, 2011.

FIGUEIREDO, Rubens. Tolstói. “Apresentação” In: TOLSTÓI, L. N. Ressurreição. São Paulo: Cosac Naify, 2010. pp. 7-13

FREUD, Sigmund. Textos escolhidos de psicanálise de Sigmund Freud. 1. Histeria. Primeiros artigos I. Rio de Janeiro: Imago editora LTDA.

GÓRKI, Máximo. Leão Tolstói. Trad. Rubens Pereira dos Santos. São Paulo:

Perspectiva, 1983.

GUINSBURG, Jacó. Stanislávski e o Teatro de Arte de Moscou, São Paulo: Perspectiva, 2001. 
. Stanislávski, Meyerhold \& cia. São Paulo: Perspectiva, 2a ed. revista, 2001.

HAUPTMANN, Gerhardt. The reconciliation. PoetLore. Volume XXI. Number v.

HEIJERMANS, H. The Good Hope: a drama of the sea in 4 acts. Dramatic Publishing Co. link: https://archive.org/details/goodhopedramaofs00heiiiala

KANT, I. "El arte bello" in: VASQUEZ, Adolfo Sanchez. Antologia. Textos de Estética y Teoria del Arte. Universidad Nacional Autonoma de Mexico. Ciudad Universitaria. Mexico 20 D.F. 1978 p.67-71

MACHADO, Irley... [et al] (organizadores) Teatro: ensino, teoria e prática - Uberlândia: EDUFU, 2004

MAETERLINK, M. O pássaro azul.

MÁRKOV. Pavel. "Pervaia Stúdia MXT (Sulerjítski, Vakhtângov, Tchekhov)". In: O teatre, $v 4$ tomakh ("O primeiro Estúdio do TAM (Sulerjítski, Vakhtângov, Tchekhov)"). V.1. Moscou: Iskusstvo, 1974

MEYERHOLD, Vsevolod. Vospominanie. In: SULERJÍTSKI, L. A. Povesti i rasskazy. Staty $i$ zametki o teatre. Perepiska. Vspominania o L. A. Sulerjitskom. M: Isskustvo, 1970.

NEMIRÓVITCH-DÂNTCHENKO, Vladímir I. "Las tres caras del diretor de escena” In: Principios de direccion escenica. Trad. Enriqueta Bernal. Pp.105-108.

Obras de Tolstói no Teatro de Arte. In: BYTSENKO, Anastássia. Liev Tolstói e o teatro: texto e contexto de o cadáver vivo. Tese de doutorado, orientadora Elena Vássina - São Paulo, 2013. Pp.187- 205

PARINI, J. "Introdução". In: TOLSTÓI, L.N. Os últimos dias/Liev Tolstói. São Paulo: Penguin Classics Companhia das Letras, 2011.

POLIAKOVA, E. I. Teatr. Sulerjítskovo: Etica, Estetica. Rejissero M: Agraf, 2006. 298p 
.Jizn i tvortchestvo L. A. Sulerjitskogo p.17-95 in: SULERJÍTSKI, L. A. Povesti $i$ rasskazy. Staty i zametki o teatre. Perepiska. Vspominania o L. A. Sulerjítskom. M: Isskustvo, 1970. 707s

RIPELLINO, Angelo Maria. O truque e a alma. Trad. Roberta Barni. São Paulo: Perspectiva, 1996.

RUDNITSKY, Konstantin. Russkoie rejisserskoie iskustvo: 1908-1917. M. : Naúka, $1990,279 \mathrm{~s}$.

SANTOS, Maria Thais. Na Cena do Dr. Dapertutto: poética e pedagogia em V. E. Meyerhold: 1911 a 1916. Sâo Paulo: Perspectiva: Fapesp, 2009.

SANTOS, Mario F. Convite à Estética. 4ed. São Paulo: Livraria e Editora LOGOS, 1966

SCANDOLARA, Camilo. Os estúdios do Teatro de Arte de Moscou e a formação da pedagogia teatral no século XX. Dissertação de Mestrado, Campinas, 2006.

SCHNAIDERMANN, Boris. Tolstói. Antiarte e rebeldia. São Paulo: Editora Brasiliense, 1983.

SCHILLER, F.: "El estado estetico del hombre". in: VASQUEZ, Adolfo Sanchez. Antologia. Textos de Estética y Teoria del Arte. Universidad Nacional Autonoma de Mexico. Ciudad Universitaria. Mexico 20 D.F. 1978 p. 21-27

SHAKSPEARE, William. Hamlet. Trad. Millor Fernandes. Disponível em: http://www.encontrosdedramaturgia.com.br/wpcontent/uploads/2010/10/ShakespeareHAMLET-Tradu\%C3\%A7\%C3\%A3oMill\%C3\%B4r-Fernandes.pdf (acesso em dezembro/2015)

SLONIM, Marc. El Teatro Ruso del império a los Soviets. Buenos Aires: Editorial Universitária, 1965.

SOURIAIU, Etienne. Chaves da Estética. Trad. Sesarina Abdala Belém. Rio de Janeiro: Editora Civilização Brasileira, 1973. 
STANISLÁVSKI, Konstantin S. Minha vida na arte. Trad. Paulo Bezerra. Rio de Janeiro: Civilização Brasileira, 1989. . . Buenos Aires: Editorial Quetzal, 1986 - Vospominanie. In: SULERJÍTSKI, L. A. Povesti i rasskazy. Staty $i$ zametki o teatre. Perepiska. Vspominania o L. A. Sulerjitskom. M: Isskustvo, 1970. 707s

TAKEDA, Cristiane Layher. O cotidiano de uma lenda. Cartas do Teatro de Arte de Moscou. São Paulo: Perspectiva: Fapesp, 2003.

TCHEKHOV, Mikhail. Vospominanie. In: SULERJÍTSKI, L. A. Povesti i rasskazy. Staty i zametki o teatre. Perepiska. Vspominania o L. A. Sulerjítskom. M: Isskustvo, 1970. 707s TOLSTÓI, Liev N. O que é Arte? Trad. Bete Torii. São Paulo: Ediouro, 2002. . Os últimos dias/ Liev Tolstói. São Paulo: Penguin Classics Companhia das Letras, 2011.

VÁSSINA, E., LABAKI, A. Stanislávski: vida, obra e Sistema - Rio de Janeiro: Funarte, 2015

VAKTHANGOV, E. Vospominanie. In: SULERJÍTSKI, L. A. Povesti i rasskazy. Staty $i$ zametki o teatre. Perepiska. Vspominania o L. A. Sulerjítskom. M: Isskustvo, 1970. 707s

В Студии Художественного театра [беседа с Сулержицким] // Евгений Вахтангов:

Сборник / Сост., Комм. Л. Д. Вендровская, Г. П. Каптерева. М.: ВТО, 1984. 


\section{ANEXOS}


FOTOS

- As fotos a seguir foram retiradas da internet e encontram-se também nos livros organizados por Elena Poliakova.

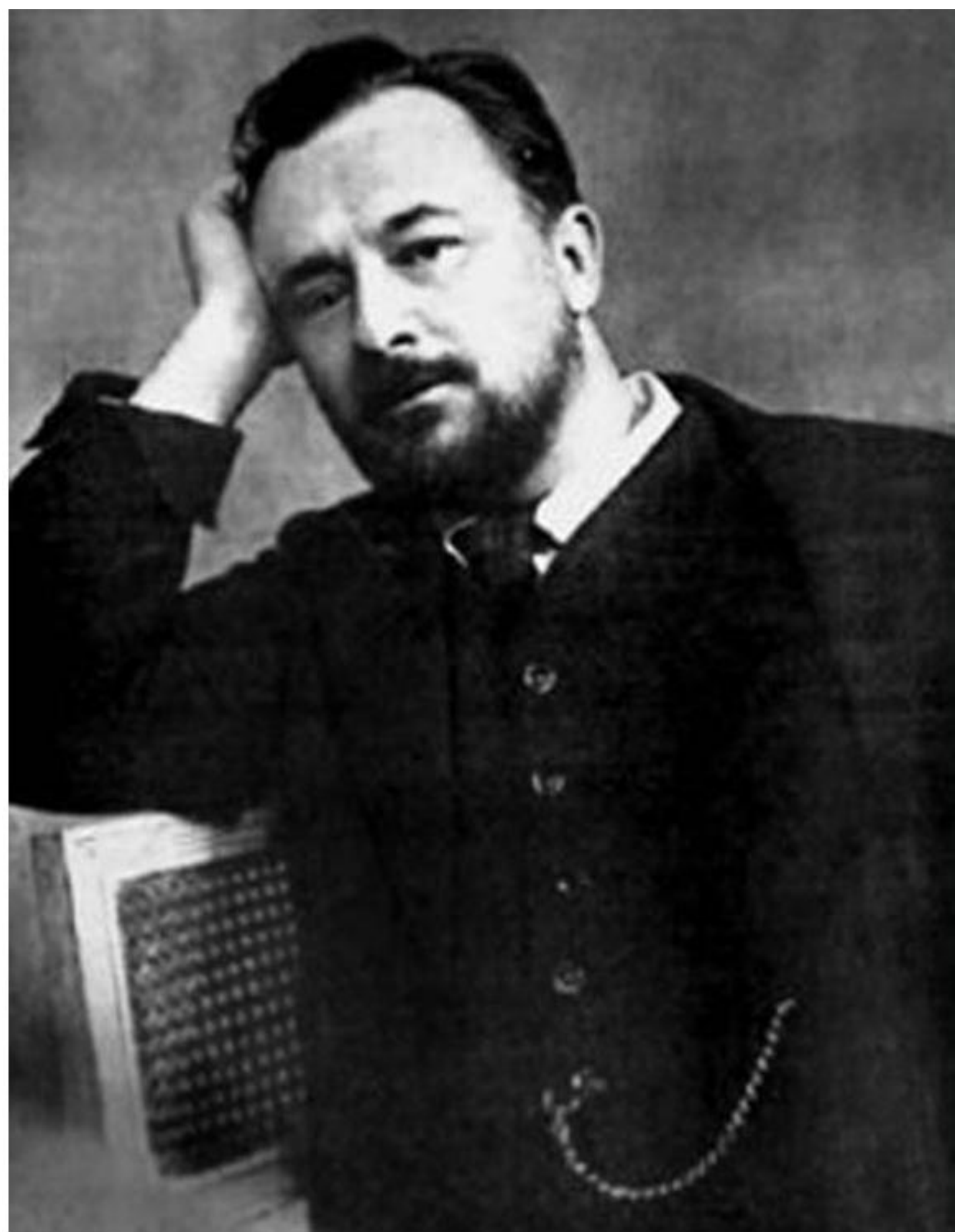

Leopold Sulerjítski 


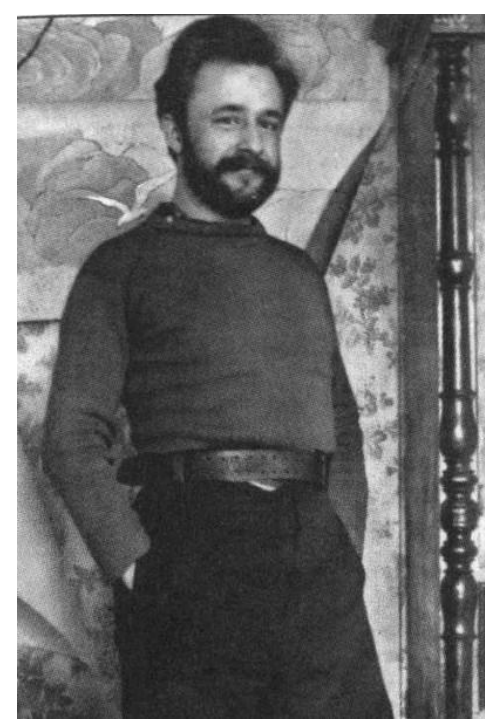

Leopold Sulerjítski

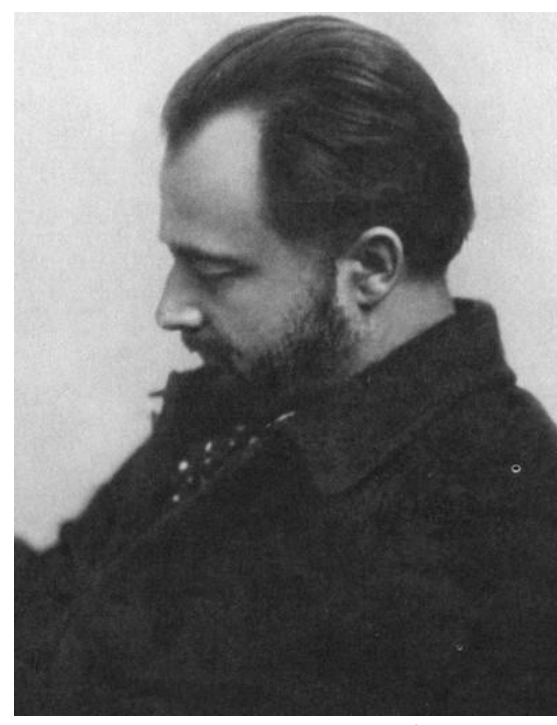

Leopold Sulerjítski

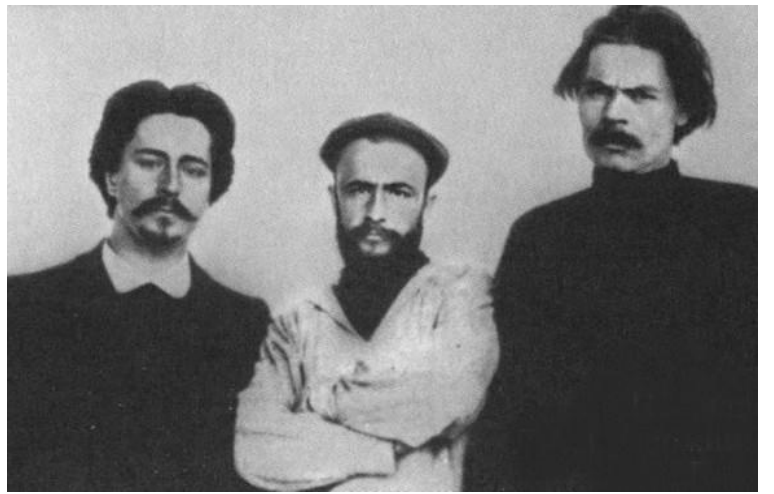

N. Andreev, L. A. Sulerjítski e A. M. Gorki

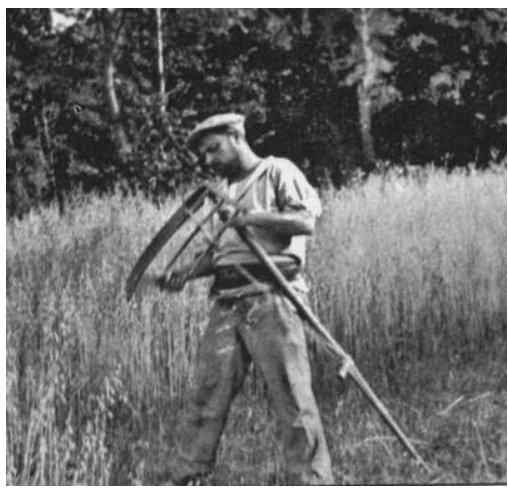

Leopold Sulerjítski no campo , 1900

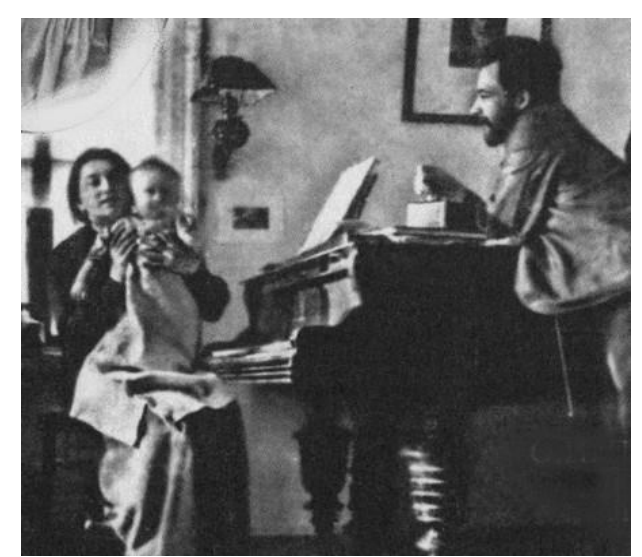

L. A. Sulerjítski com sua esposa e o filho.

Em sua casa. 
- Fotos retiradas da internet:

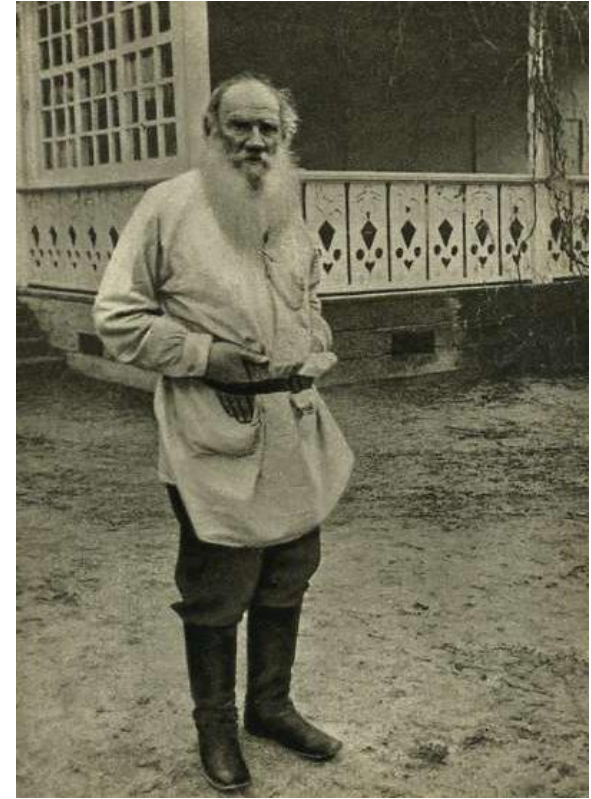

Lev Tolstói

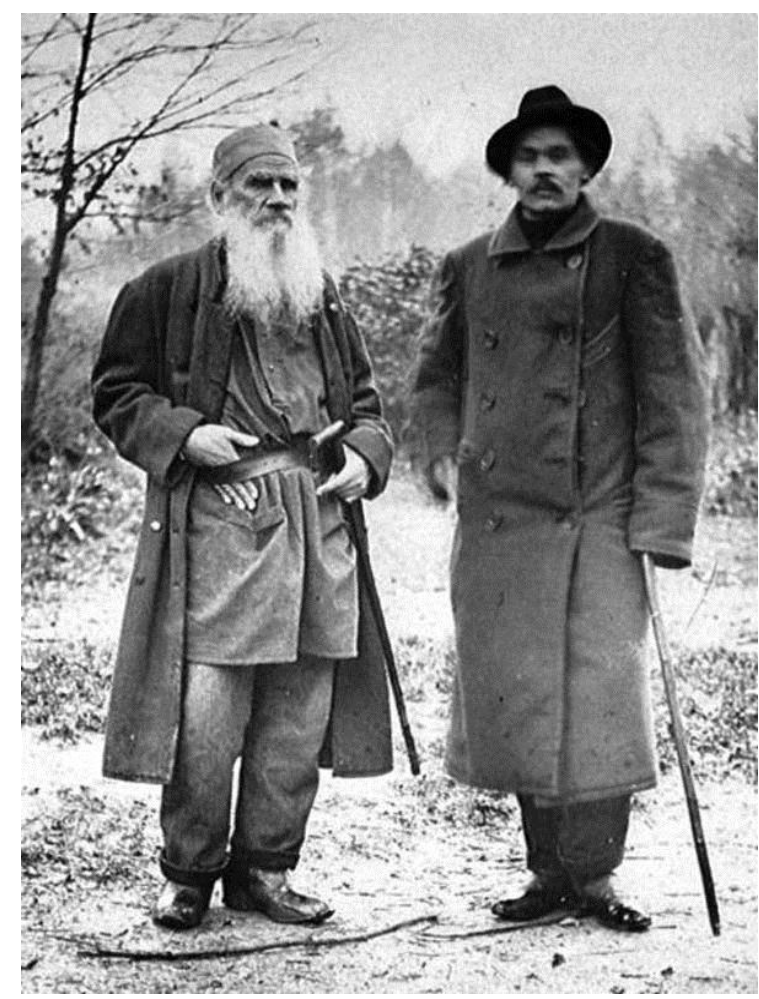

Lev Tolstói e Maximo Gorki

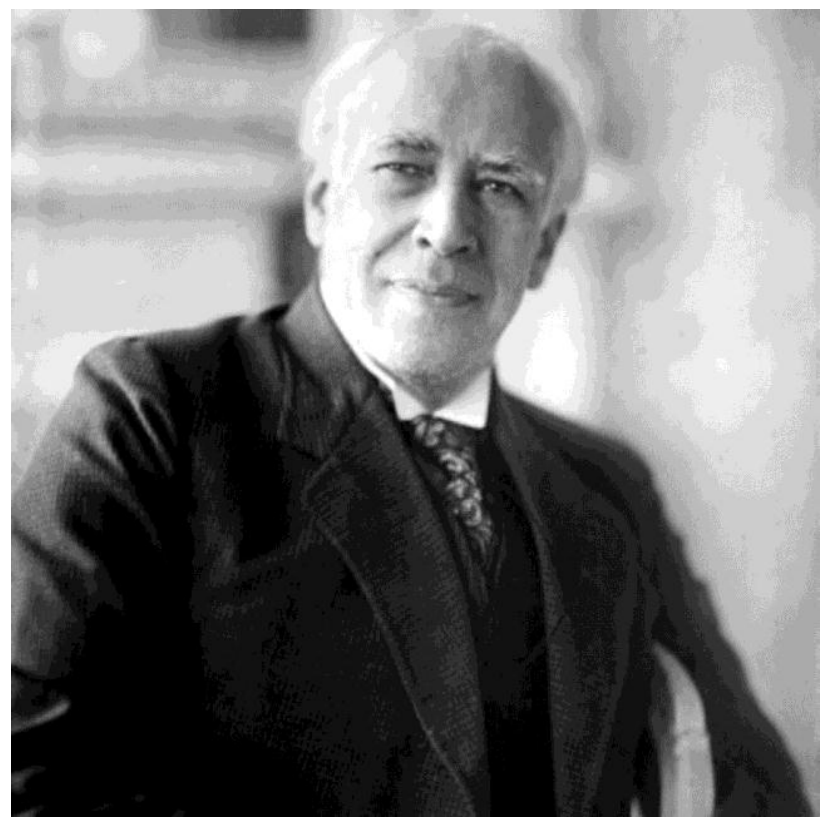

Konstantin Stanislávski

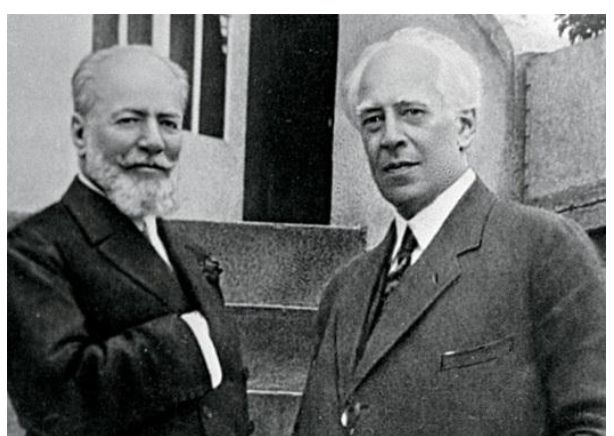

Nemirovitch-Dântchenko

Konstantin Stanislávski

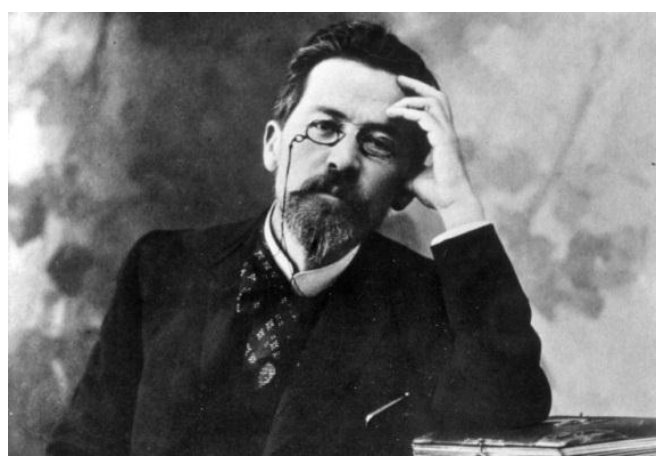

Anton Tchekhov 
Alguns dos alunos do Estúdio mencionados neste trabalho:

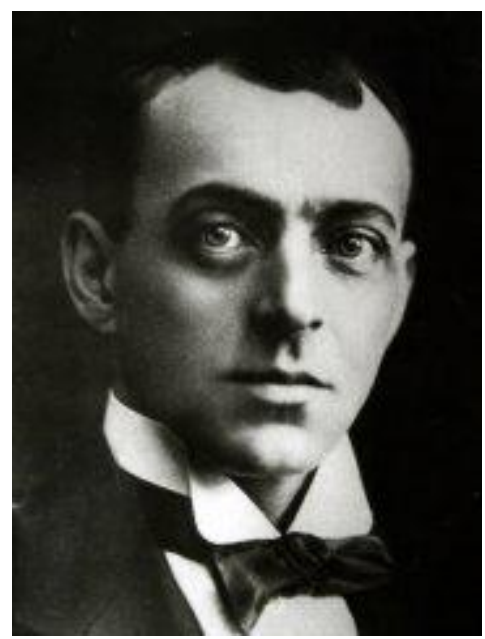

Evguênie Vakthângov

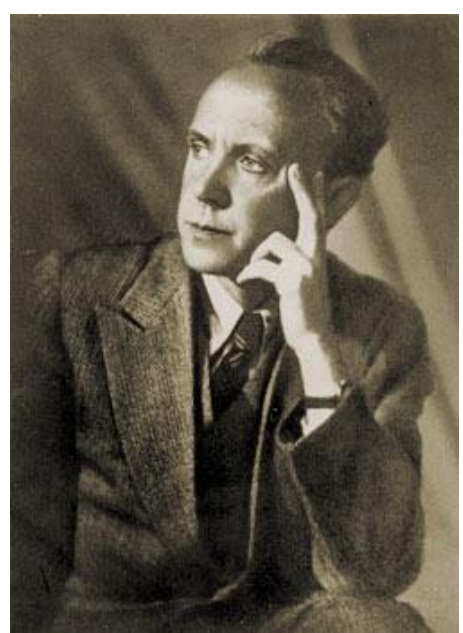

Mikhail Tchekhov

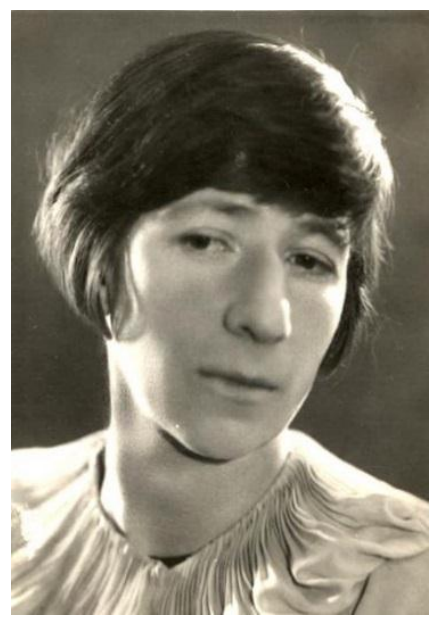

Serafima Birman

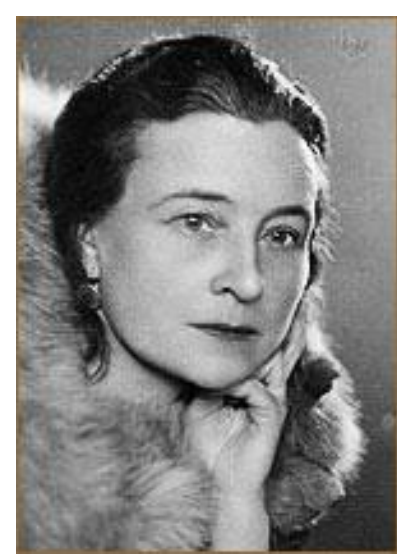

Sofia Vladimirovna Giatsintova

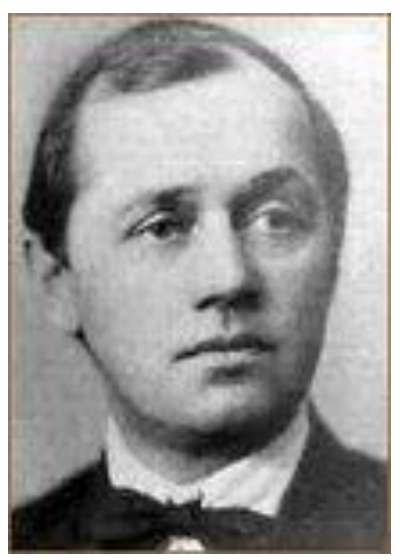

Valentin Sergueevitch Smyshliaev

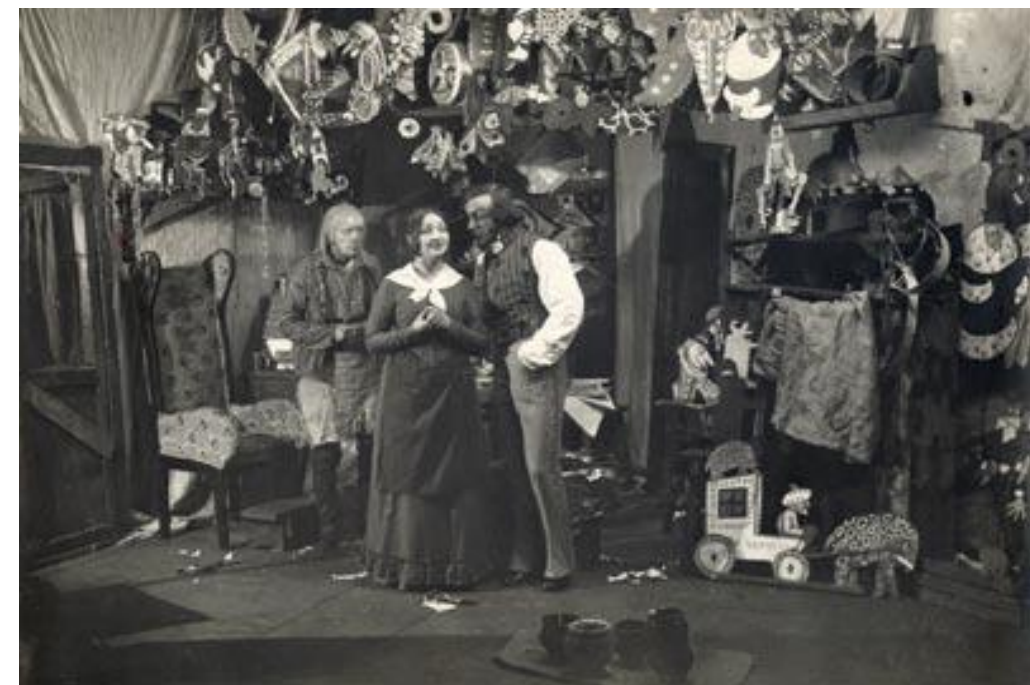

Cena de "O grilo na lareira" apresentada pelo Primeiro Estúdio do TAM (Foto presente também no livro de E. Poliakova) 
- A sequencia de fotos a seguir foi tirada por mim durante a bolsa BEPE financiada pela FAPESP durante três meses em Moscou.

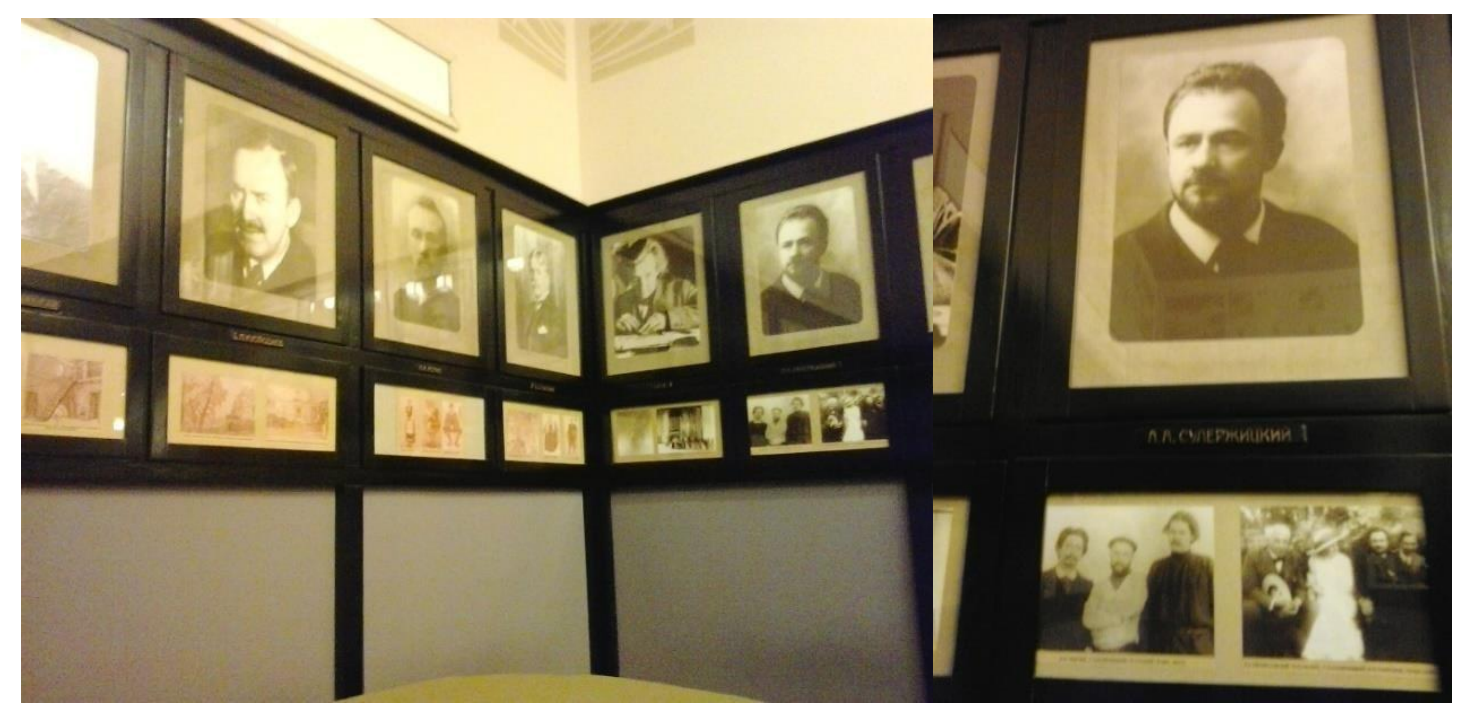

Fotos de L. A. Sulerjítski no Hall do Teatro de Arte de Moscou Tchekhov.
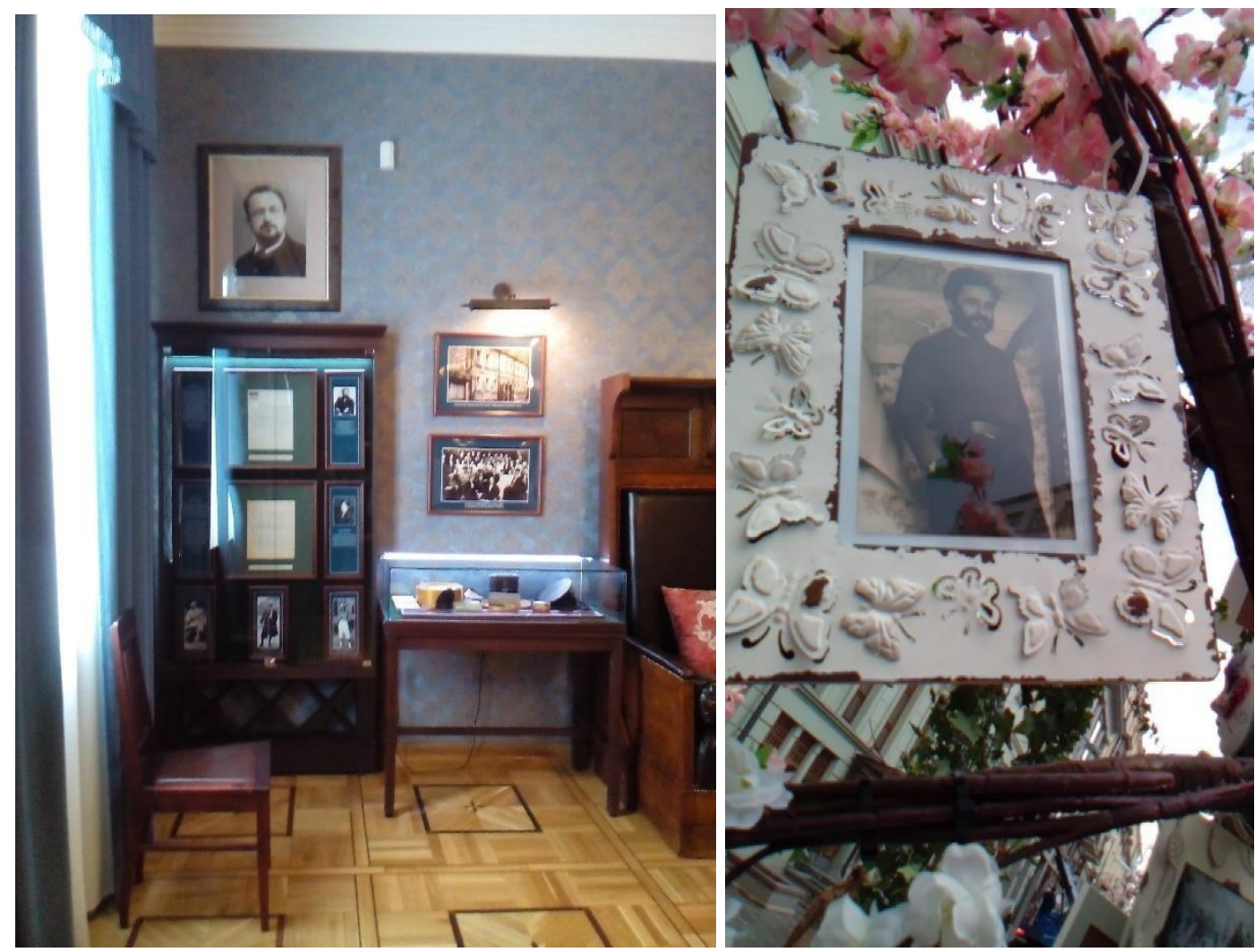

Fotografia de L. A. Sulerjítski no apartamento-museu de E. Vakthângov
Fotografia de L. A. Sulerjítski pendurada emu ma das várias árvores temáticas que decoram a cidade em Abril. 


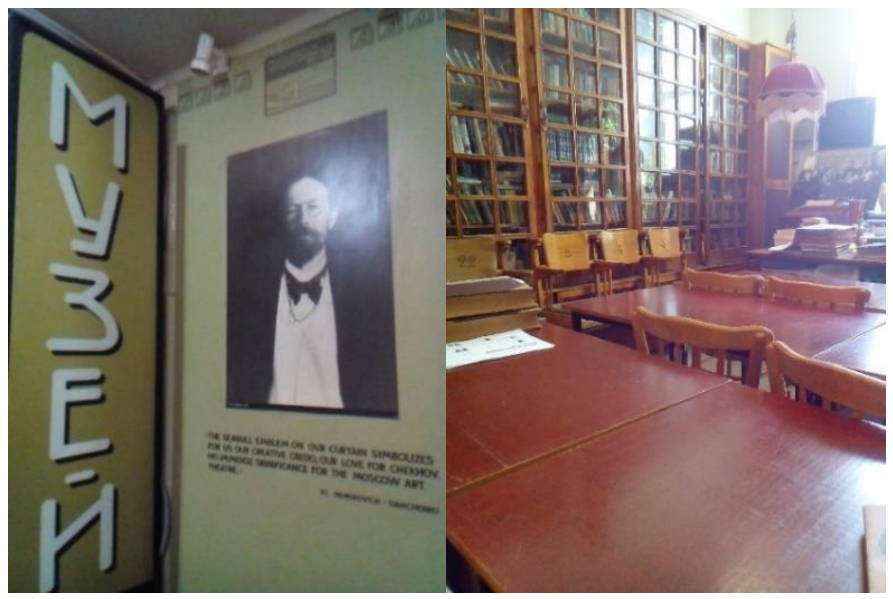

A biblioteca de Arte de Moscou por dentro.

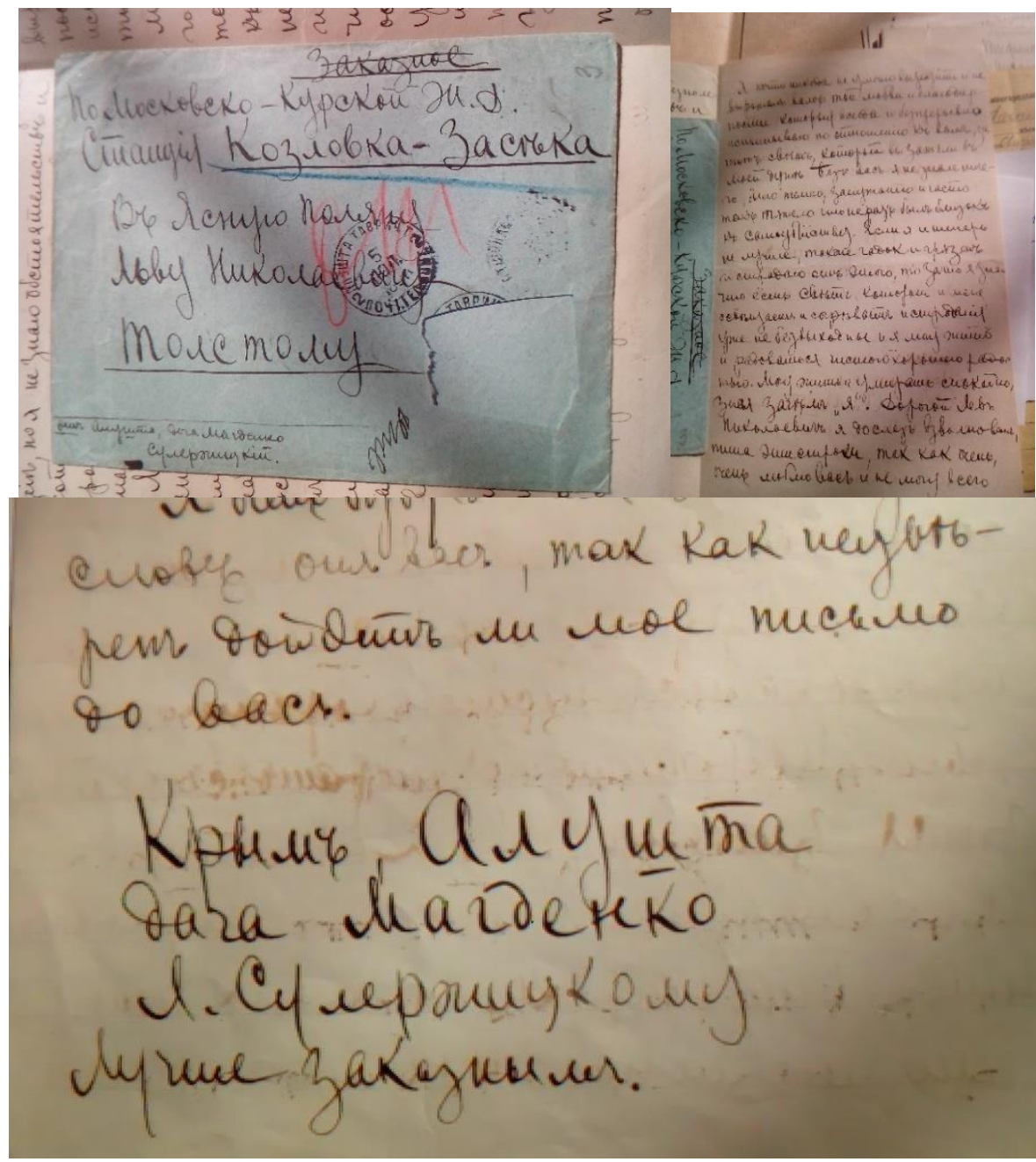

Cartas encontradas no Museu Lev Tolstói 


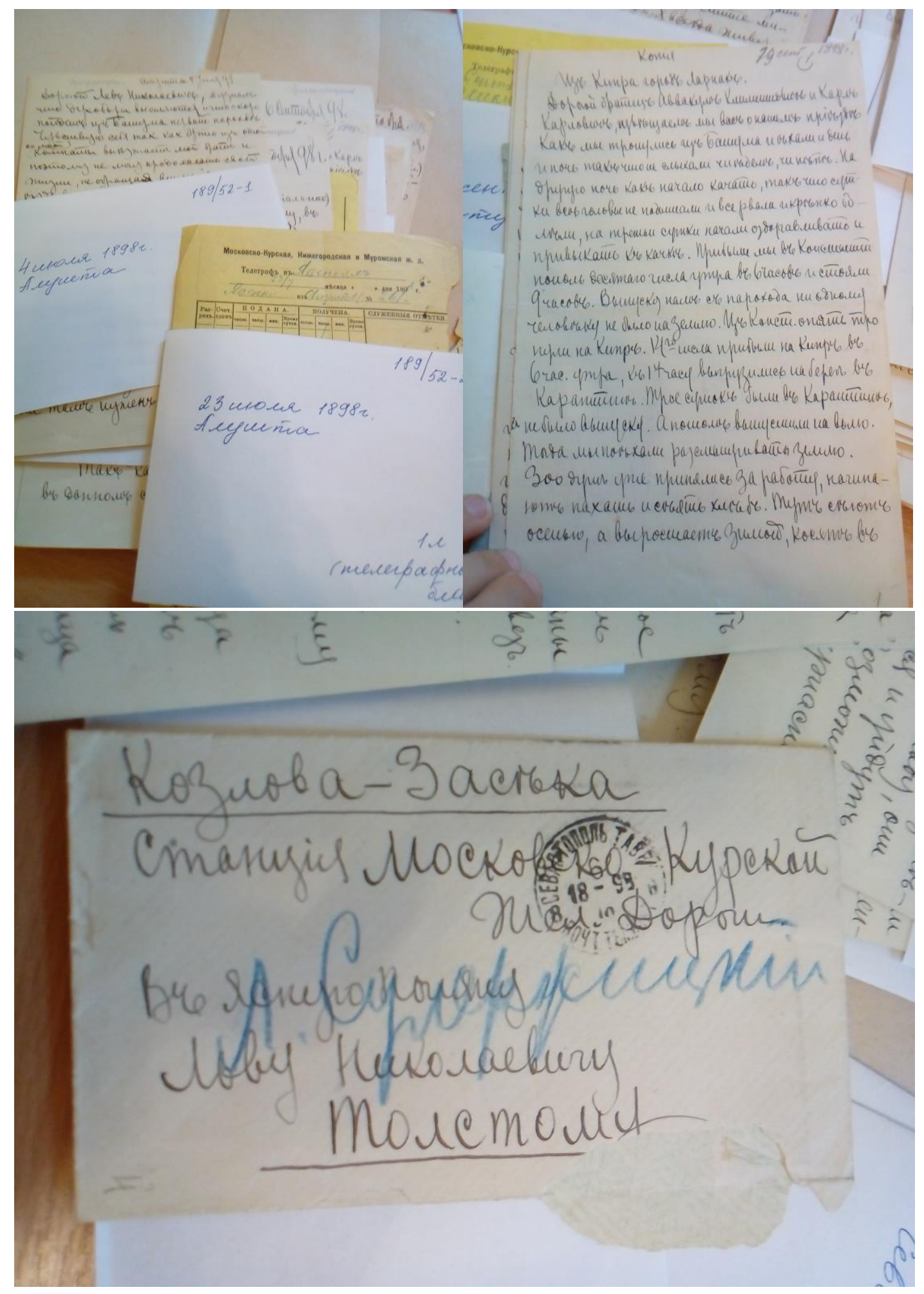

\section{Cartas encontradas no Museu Lev Tolstói}




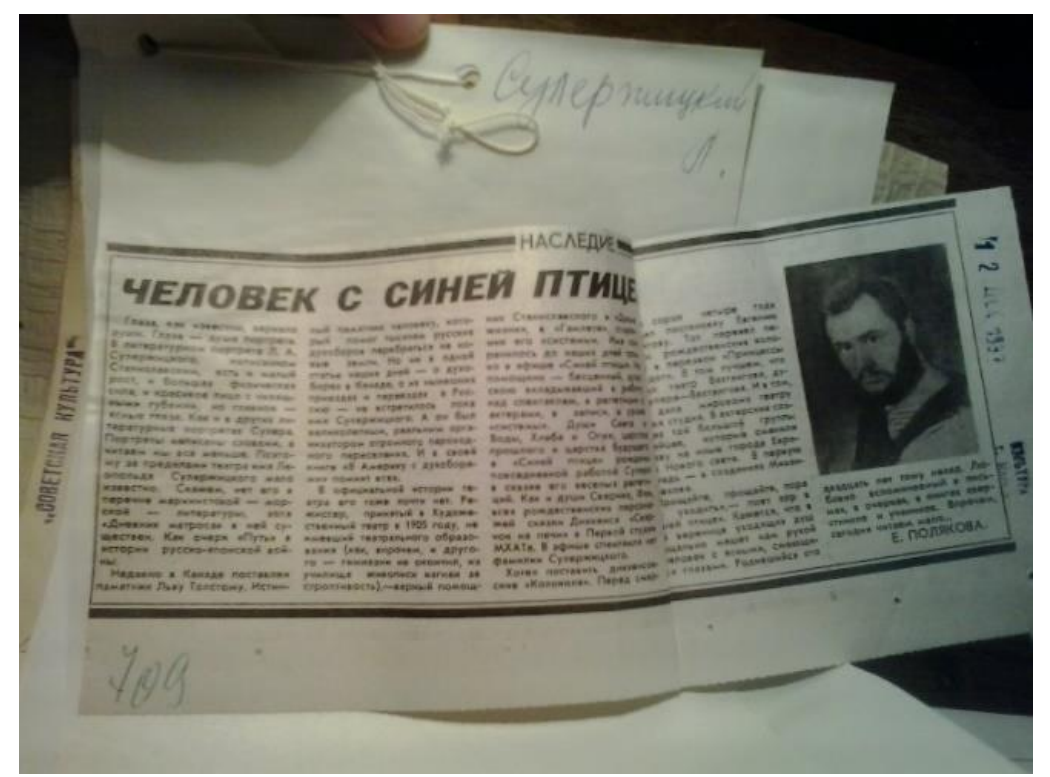

Recorte de jornal encontrado na Biblioteca Teatral da Bolshaia Dmitrovka.

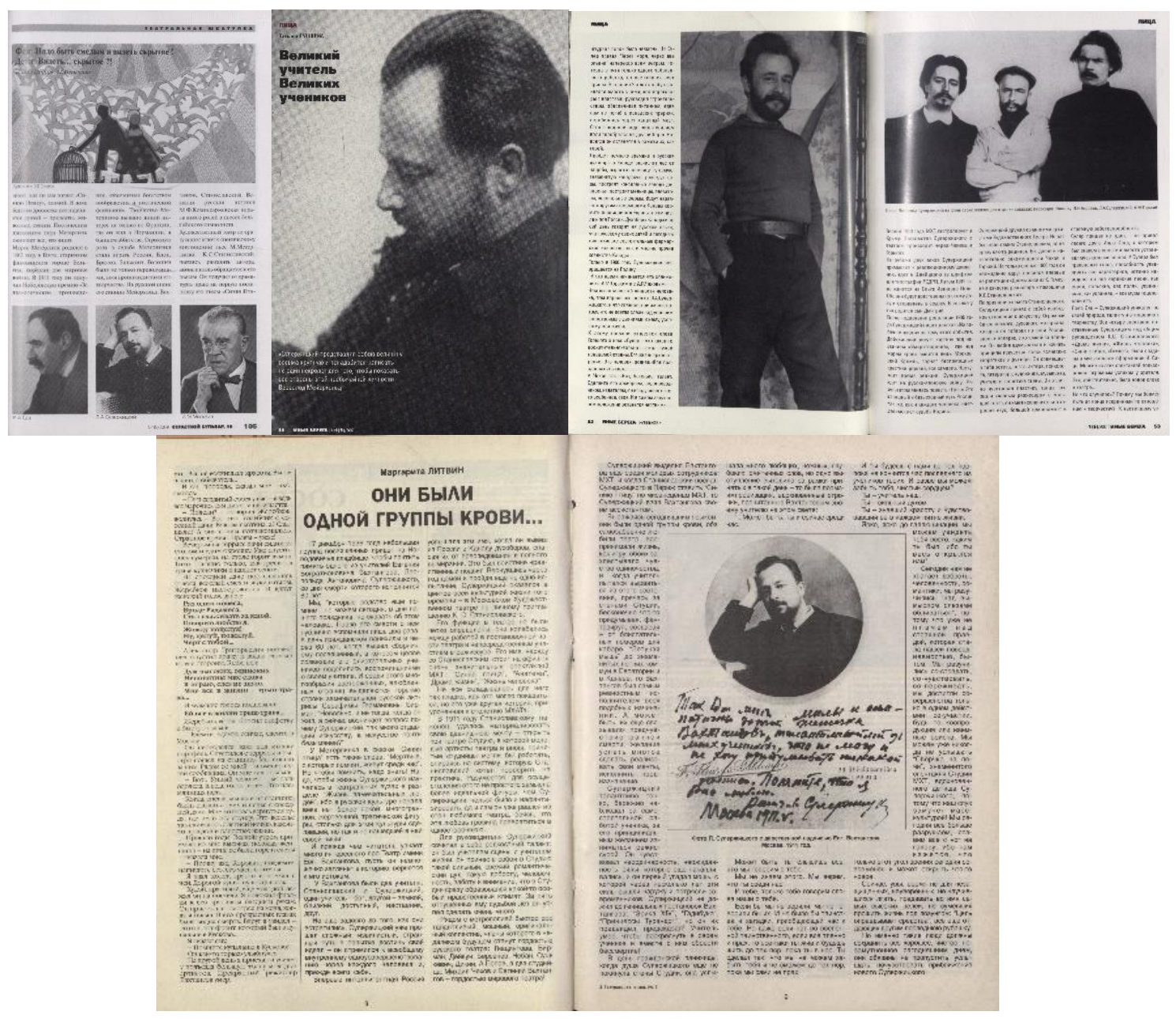

Materiais encontrados na Biblioteca estatal de Arte. 

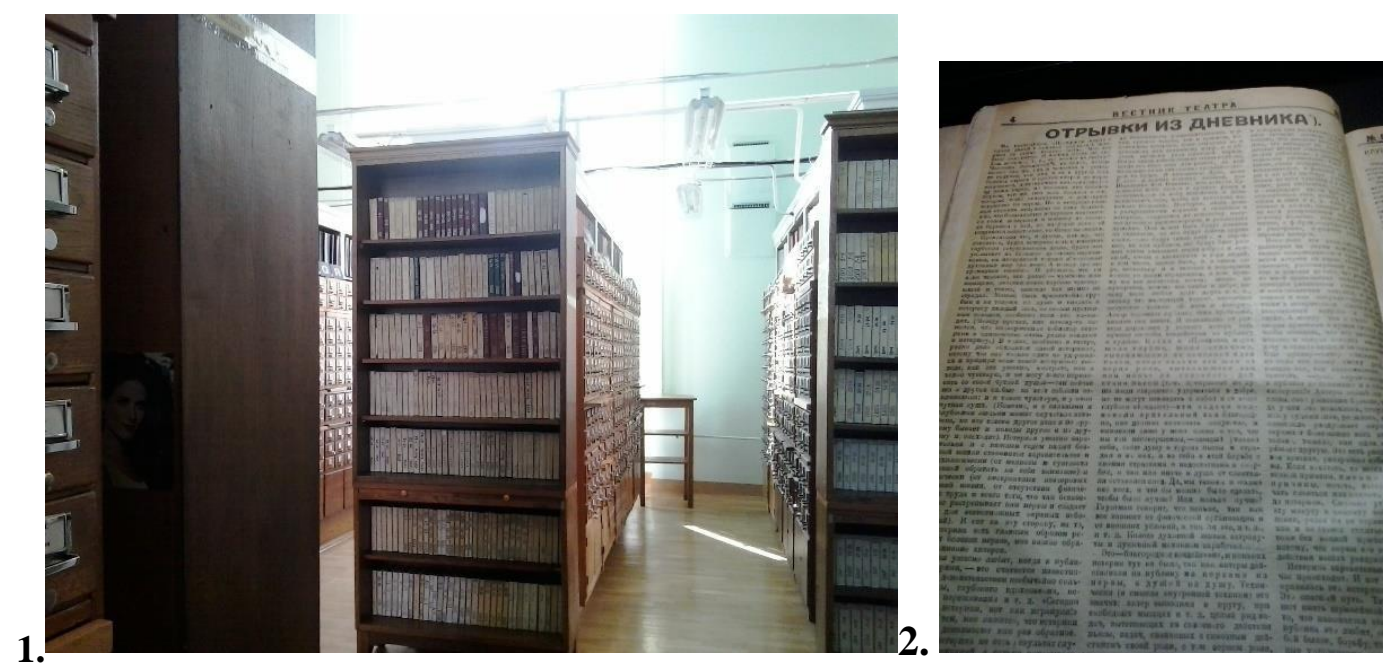

1. Biblioteca Lenin por dentro.

2.Anotações de diário de 1913 sobre a hysteria e publicadas no jornal Vestnik Teatra em fevereiro de 1919. O jornal é conservado atualmente na Biblioteca Lenin

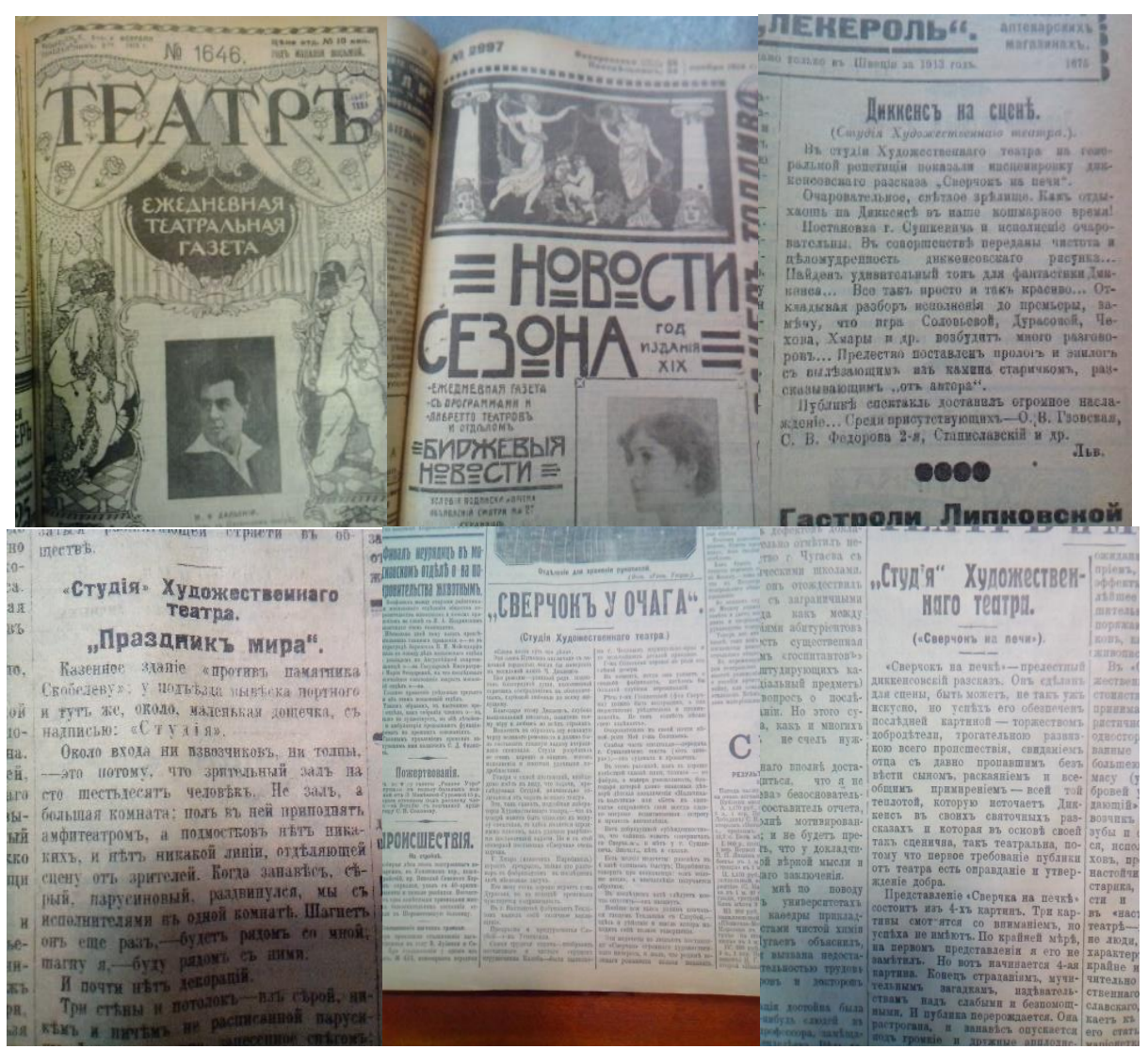

Alguns dos jornais encontrados em Khimki, Biblioteca filial da Biblioteca Lenin em Moscou. 


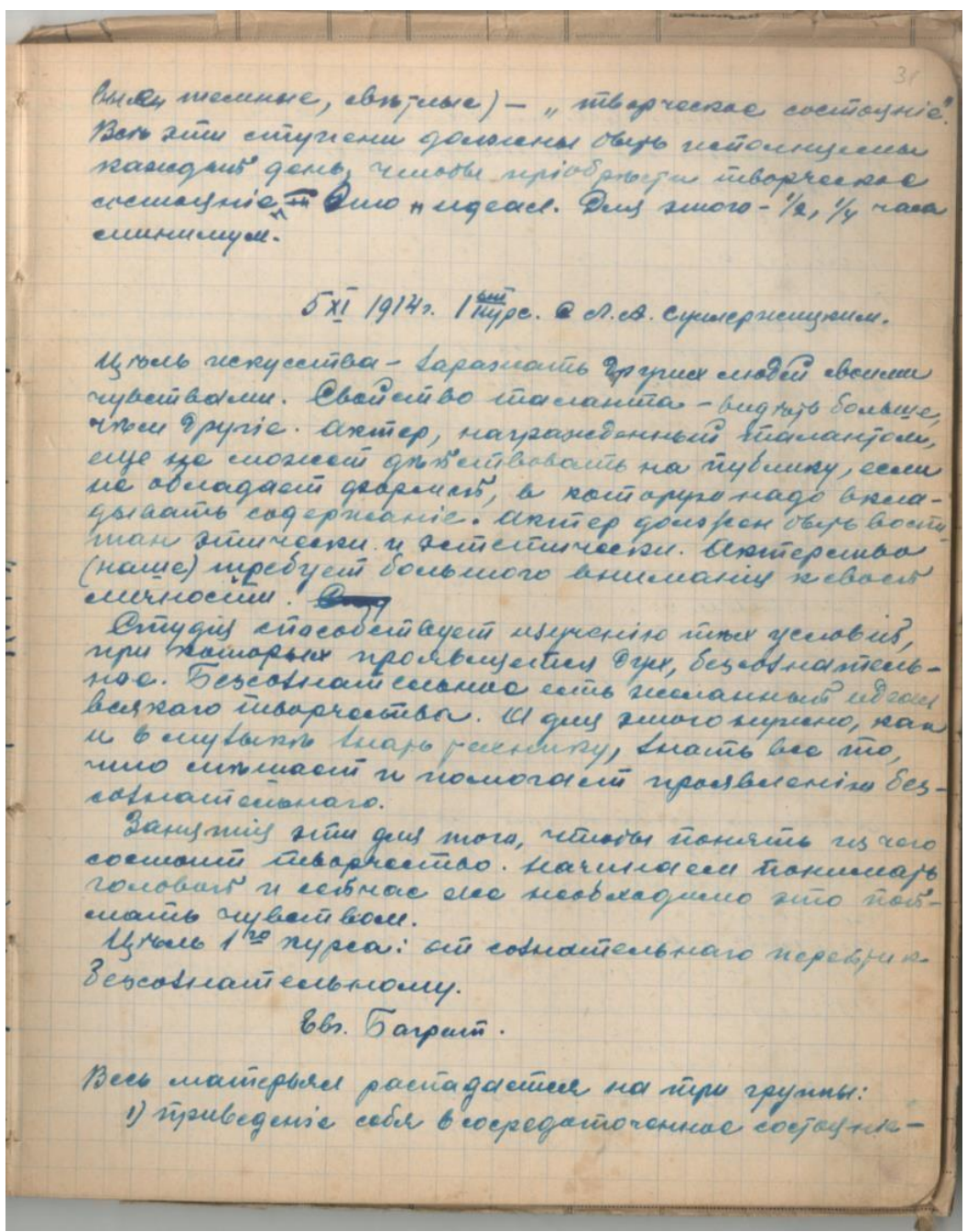

Página do caderno de Serafima Birman (incluida neste trabalho) escrita em 1914. Material encontrado nos arquivos da Biblioteca de Arte e Literatura de Moscou.

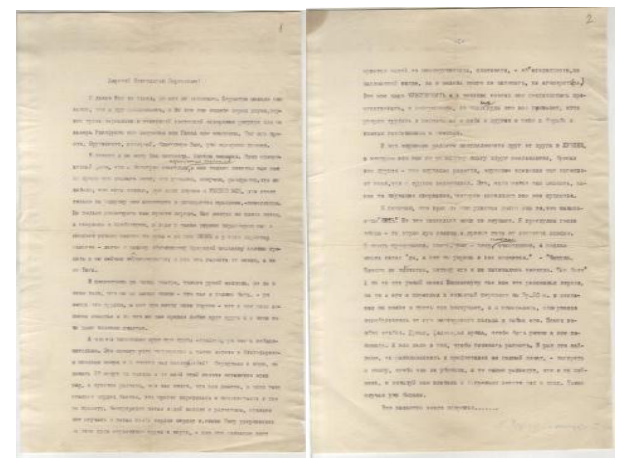

Carta de Sulerjítski para Stanislávski. Biblioteca de Arte e Literatura de Moscou. 
Tradução: Sobre as relações entre ator e diretor ${ }^{118}$ (1909)

O único diretor que tentou sentir a área de ideias decadentes - como a chama o senhor Davídov ${ }^{119}$ - , foi Meyerhold com seu Teatro de Convenção, o jogo na superfície e etc. Mas esta tentativa, sendo erroneamente fundamentada, em muito curto prazo exauriuse. E grandes atores como Komissarjévskaia e Brávitch ${ }^{120}$, que ficaram entusiasmados com as novas formas, tiveram a acertada intuição de um grande talento e rapidamente sentiram que se avançassem por este caminho, arriscariam, por assim dizer, deslocar seus temperamentos e perder a sinceridade, sem a qual não é possível nenhuma arte. Eles abandonaram a tempo um caminho arriscado para si.

Mas quem dos que viam o teatro de Meyerhold e conheciam os demais teatros, dirá que ele contaminou o teatro com sua influência? Se houvesse tido influência, esta seria apenas negativa, pois Meyerhold, não obstante os imensos conhecimentos teóricos, mostrou com clareza e nitidez como "não se deve fazer".

Esta questão sobre as relações entre o ator e o diretor e suas condições no teatro é debatida há tempos em palestras.

Antes, os neorromânticos ou os decadentes insistiam que o realismo no teatro destruía os atores e que para a sua salvação era necessário o Teatro de Convenção. Agora os neorrealistas afirmam que é o Teatro de Convenção, propriamente falando, que arruina o ator. E ambos demonstram que o culpado é o diretor. A situação seria absolutamente sem saída se esta questão de fato existisse.

Mas para a nossa sorte, na prática esta questão não existe. Logo, ela se resolve por si mesma, pela própria natureza das coisas. Em seu aspecto insolúvel ela existe apenas

\footnotetext{
${ }^{118}$ Fragmento de uma apresentação realizada por Sulerjítski em 25 de outubro de 1909 no Museu

Politécnico, após a conferência feita por A. P. Davídov intitulada "Sobre o grande ator". Publica-se aqui os rascunhos das anotações, conservados no Museu do TAM (Número 8308/2). Davídov afirmou que o teatro de convenção humilhava e despersonalizava o ator. Sulerjítski, em contrapartida, defende o "novo drama", o "teatro místico" como ele chamava, demonstrando que estas peças como "A vida de um homem" de L; Andreev ou a dramaturgia de Maeterlink fomentam o progresso da arte do ator. Sulerjítski objetando Davidov, e não aceitando "diretores decadentes" em geral, julga que o único dos diretor decadente contemporâneo é Meyerhold. Á posição de Sulerjítski para com a direção de Meyerhold e as relações entre ator e diretor em geral é também dedicada ao máximo uma interessante parte da apresentação publicada por nós. As teses restantes, são insuficientemente detalhadas e argumentadas nas anotações de sua apresentação. Além de Sulerjítski estiveram no encontro S. Iablonovski e K. Marjanov, etc. Um relatório detalhado sobre o encontro foi publicado em "Russkoe Slove" (26 de outubro de 1909) (N. ed. Russa)

${ }^{119}$ Vladímir Nikoláevitch Davídov ( 1849-1925) - ator dramático.

${ }^{120}$ K.V. Brávitch - Conhecido ator e diretor que esteve trabalhando com Komissarjévskaia de 1909 a 1912 - ator do Teatro Máli (N.ed. Russa)
} 
nas palestras onde, eu acho, ainda não será resolvida por muito tempo. Frequentemente acontece assim, que uma questão há muito resolvida na prática, na teoria não consegue ser resolvida por gerações inteiras. Aí está uma dessas questões.

Como é solucionada esta questão na prática?

Em duas palavras, Stanislávski formulou assim: se o diretor for mais talentoso do que o ator, ele o levará atrás de si; se, pelo contrário, o ator for mais talentoso do que o diretor, então o ator levará consigo o diretor, conforme foi possível ver recentemente num exemplo do Teatro de Arte.

Será que realmente é possível fazer algo contra a vontade de algum ator, ainda que ele tenha pouco talento, que seja só um pouquinho artista, e não um ártifice assalariado, não um paiats $^{121}$ ?

No campo da arte e da criação não se pode de jeito nenhum nem forçar e nem mandar nos sentimentos. Nenhum ator, mesmo o de menor talento, mudará sequer uma característica da personagem que ele mesmo criou durante todos os tormentos da criação, ainda que o próprio Stanislávski tenha lhe ordenado isso. Outra coisa: se o diretor que percebeu a individualidade do ator, souber colocar diante de sua vontade criadora os objetivos mais atraentes e entusiasmar com alusões notáveis a sua fantasia no indispensável para as peças e conjuntos de sentido, abrirá para ele as mais profundas perspectivas, e neste instante o ator sensível irá atrás do diretor. O insensível, para lugar nenhum.

Aqui, quem enxerga com maior clareza, quem sente com maior força e quem mais se entusiasma é quem está na frente.

Mas não é só isso. Por maior que seja o talento do diretor, por mais que ele desenhe espaços belos e sedutores e por mais apaixonante que seja a sua chama, se o diretor fizer tudo isso sem contar com a individualidade de dado ator e com a presença de suas características, seus hábitos e costumes, o ator ficará frio e refratário, o seu coração será fechado e, dessa vez todo, o trabalho do diretor estará perdido.

O mesmo acontecerá também neste caso, se o ator possui um grande dom para penetrar no espírito do papel, se sente mais claramente as cores, orienta-se com maior refinamento nas curvas psicológicas do papel, ama mais, brilha mais e é exatamente por isso que encanta. O diretor inevitavelmente irá atrás dele e, sob a sua influência - não

\footnotetext{
${ }^{121}$ Palhaço, bufão, bobo.
} 
apenas pela atuação em dado papel, mas também pela atuação de toda a peça -, encontrará outras belezas e abrirá outros horizontes poéticos.

Assim acontece na vida. E é difícil aqui dizer, se o diretor tem direito a ser mais talentoso do que o ator, ou se é permitido ao ator ser mais talentoso do que o diretor e com a força de seu talento seduzi-lo até a mais pura e alta beleza.

É assim em traços gerais. Mas não podemos esquecer que raramente o papel se cria de uma vez no ator, com inteireza e unidade. Estas surpresas felizes são igualmente raras no destino de qualquer artista, e quando isso acontece, quem ousa referir-se a tal filho de Deus?

A maior parte dos atores se vê obrigada a trabalhar, sofrendo infinitamente em cima da criação de um papel, procurando nele gradualmente aqueles elementos que podem despertar o interesse e seduzir. Mas acontece também de o ator fracassar em tais papéis amaldiçoados, os quais não consegue abordar de modo algum.

E agora, neste período de trabalho a paciência do diretor deve ser inesgotável. Um número considerável de ensaios passa enquanto o diretor espera, sem mexer no ator e nem o atrapalha, até que ele começa a aquecer-se em seu trabalho e o papel, de um modo ou de outro, se aproxima de seu coração.

E nesse momento, quando neste período um talento tão universal como Stanislávski esboça ao ator paralisado as cores de sua inesgotável paleta ou, como faz outro admirável diretor do nosso tempo, Nemirovitch Dántchenko, abre-lhe as mais finas construções psicológicas da formação de peças e papeis, já é mais fácil para o ator sair do ponto morto. Pode ser que ele não pegue nenhuma daquelas cores que a mão generosa de Stanislávski vai oferecer-lhe, pode ser que não concorde com a interpretação do papel de Nemirovitch, mas quaisquer fios pouco perceptíveis entre o coração do ator e o papel já se estabeleceram: ele desperta interesse pelo papel, sua vontade criadora acorda, ele começa a trabalhar. A princípio, sentirá um ou dois pontos em todo o papel, depois estes pontos vão se estender, aumentar em proporções, nascerão novos, e todos juntos no final das contas se unirão num todo.

Todo o intenso trabalho de um diretor contemporâneo em relação ao ator consiste precisamente nisto: em ajudá-lo a encontrar-se a si mesmo, ajudá-lo, como dizem, a "revelar" sua personalidade até uma grande profundidade possível, ajudá-lo a separar em seu trabalho aquilo que de fato representa sua verdadeira individualidade, do geral, do teatral, do assim chamado "clichê", que apesar de ser próprio de cada um, sendo em cada 
ator diferente do que é nos demais, não tem nada em comum com a sua verdadeira individualidade.

Todo ator sempre tem no estoque alguns "clichês" preferidos (uns têm dois, outros três ou seis). E quando o ator está vazio, quando o papel não se dá, mas é preciso tanto falar quanto atuar de uma forma ou de outra, imediatamente aparece um "clichê" ou uma combinação deles para ajudar. Esta maneira convencional, este clichê que em alguns atores é extraordinariamente agradável, encantador e até nobre, na maioria dos casos é tomado por individualidade na imprensa e no público, visto que cada ator é outro, ainda que sua construção interior seja sempre a mesma.

$\mathrm{Na}$ verdade, esta maneira exagerada da atuação é a pior inimiga da verdadeira vivência individual.

Não me estenderei sobre isso, por que até os grandes talentos não estão livres desta praga maligna - ainda que por vezes também bela - e isto nos desviaria demasiadamente da palestra.

Surpreender, celebrar com amor cada momento realmente individual que o ator tem, perceber por quais caminhos ele conseguiu chegar a essa verdadeira elevação, perceber o que nesse processo, o ajudou e o que atrapalhou e criar para sua individualidade as condições mais oportunas - eis o trabalho do diretor em relação a cada ator. E tal trabalho exige de ambos, que vivam em comunhão durante todo o trabalho. Se começam relações inimigas, a corrente é interrompida e o trabalho pára.

Mas além do ator há ainda o autor, há a peça inteira, inconcebível sem o ensemble. Aqui começa um novo obstáculo que exige por vezes enorme esforço da imaginação, que exige extraordinário tato e intuição do diretor. Para cada individualidade é preciso criar ao máximo a mais proveitosa situação, de modo tal que isso não apenas não perturbe o ensemble ou não contradiga a ideia da peça, mas, pelo contrário, para que isto contribua para seu esclarecimento e esplendor.

Um ator, por exemplo, pelo caráter de seu temperamento não pode desenvolvêlo corretamente se a montagem está criada à base de mise-en-scènes ricas em movimentos. A abundância de transições e dos movimentos rouba sua sinceridade e dirige-o para um temperamento muscular errôneo e apenas nas mise-en-scènes mais tranquilas ele pode vivenciar corretamente, encontrar-se e etc. Não dou exemplos: isso tomaria demasiadamente muito tempo. 
Que em cada arte é imprescindível a harmonia, isto, me parece, nem é preciso provar.

Mas será que a harmonia é possível apenas após o aniquilamento da personalidade?

Eu pessoalmente acho que onde há o aniquilamento da personalidade, não há lugar para uma conversa sobre a harmonia.

Uma vez que não há personalidade, não há nada, e não há nada para ser conduzido à harmonia; tudo torna-se trivial e indiferente.

Se toda uma orquestra se preencher de cornetas que sabem emanar apenas uma nota musical, então é pouco provável que até mesmo um contrapontista como Serguei Ivánovitch Taniéiev comece a escrever uma sinfonia para tal orquestra.

Por outro lado, quanto mais vivas as matizes de cada instrumento isolado, quanto mais vasto e flexível o diapasão deles, tanto mais plena e mais forte harmonia é possível, e maior talento é preciso para este maestro e compositor.

Eu não queria referir-me ao TAM, embora eu fale apenas em meu nome, mas permitam-me todos perguntar: será possível interpretar "As três irmãs" com atores sem personalidade?

Ou, melhor: se nos mostrassem que a trupe é constituída por Salvini, Tina de Lorenzo, Duze ${ }^{122}$ e outros artistas desta grandeza, como sairia grande o ensemble! É verdade, que uma trupe assim precisaria de um diretor com um talento da mesma grandeza, já que quanto maior a individualidade dos atores, mais eles precisarão de um diretor com maior talento e sensibilidade, e não o contrário, como se costuma pensar.

E é por isso que o efeito de um ensemble assim seria impressionante, porque nem um dos interpretes escaparia da harmonia, visto que o seu instinto artístico não lhes permitiria e não haveria meios de dizer que cada um deles em particular foi privado da individualidade.

Sendo assim, o bom ensemble não prova nem um pouco a fraqueza de cada ator que o compõe. Se o ensemble é realmente bom, isso mostra apenas que além dos atores bons e brilhantes, o teatro possui pelo menos um bom diretor também.

Pois bem, eu afirmo que um bom ensemble só é possível para os atores com individualidades fortes se junto houver um diretor desse tipo.

\footnotetext{
${ }^{122}$ Tommazo Salvini (1829-1916), Eleonora Duze (1859-1924) - célebres atores trágicos da Itália. Tina de Lorenzo - Popular no início do século XX; atriz italiana que estava com sucesso em tournée artística na Rússia (N. ed. Russa)
} 
Mas pode ser que algum dia surja uma individualidade assim tão impetuosa, que não queira caber em qualquer ensemble e que deseje toda a atenção do espectador concentrada sobre si. Como será então?

Se por acaso surgisse tal ator, ou ele seria obrigado a abdicar de tudo no repertório existente e passar para o monodrama, ou a colocar-se na deplorável situação de artista em tournée. Deplorável, digo, pois se algo é mais antiartístico e ingrato para o homem de talento do que o sistema do artista em tournée eu não sei.

Não podemos esquecer que o ensemble, impossível sem a existência do diretor, é necessário enquanto atuam Tchekhov, Hauptmann, Andreev, Ibsen, Knut Hamsun. Aproveitar-se das peças destes autores como arenas isoladas para concursos de atores por sucesso do público, dilacerar de forma bárbara os papéis separados, ignorando a ideia da própria peça e sua integridade, já é impossível. O público cresceu tanto, a imprensa cresceu tanto, as exigências artísticas em relação ao teatro cresceram tanto, que voltar à situação da dramaturgia anterior à reforma, agora talvez fosse impossível. E o ator que se permitisse não levar em consideração a peça ou o autor, seria chamado não de individualista, mas simplesmente de homem inculto de mau gosto, semelhante àquele homem que erroneamente aproveitando-se do conceito de liberdade sai para a rua e, para afirmar sua personalidade, dá uma surra em cabeças de transeuntes, não seria chamado por nós de individualidade, mas de bandido e desordeiro.

A mim resta dizer umas poucas palavras sobre o teatro de Convenção e o teatro estilizado como um fator de destruição ou desenvolvimento da personalidade do ator... Se falarmos sobre a convenção e a estilização naquele sentido que exigia do ator Meyerhold, ou seja, introduzir vivências sinceras no plano externo das construções de entonação e postura, fazendo isto a partir do olhar e da audição; então aqui realmente o ator cairá em tais condições, onde ele já não pode simplesmente viver sincera e fisiologicamente, e logo, manifestar de uma ou de outra maneira a sua personalidade. Privado de seu "eu" ele realmente cai nas mãos do diretor na qualidade de material privado de personalidade e pode ser colocado no cenário de duas dimensões, em frente de uma cortina preta - em uma palavra, posicionar como e onde quiser.

Aqui o talentoso e inteligente Vsévolod Emílevitch Meyerhold cometeu um erro. Esquecendo-se do ator, ele foi até o Teatro de Convenção, até a negação dos verdadeiros detalhes. Armado de excelentes conhecimentos no domínio da representação teatral, sabendo penetrar profundamente nas ideias do autor e manobrá-las perfeitamente, já que 
elas são abstratas, Vsévolod Emilevitch, se afunda impotente nas profundas vivências dos homens vivos, perdendo-se entre a forma e o conteúdo. Em sua aspiração à criação de novas formas de teatro ele desprezou o ator e pagou um preço alto por isso.

Stanislávski, que estava criando o Teatro-Estúdio, onde ele trabalhava junto com Meyerhold na criação do teatro de Convenção, quando já estavam prontas algumas peças e era possível dar início à temporada, viu que não havia atores para a atuação no teatro de Convenção com as telas ao fundo, que por enquanto os atores não podiam fazer isso; dissolveu a trupe e fechou o Estúdio. E então transferiu o trabalho sobre o teatro de Convenção, mas já com uma base completamente diferente, para dentro das paredes do Teatro de Arte. Mas Meyerhold separou-se e organizou o próprio teatro, o qual nós vimos.

Eis que apenas aí, apenas nisso, em como Meyerhold colocou o ator no teatro de Convenção, estava precisamente aquilo que o conferencista teme com toda a razão, isto é, que tal convenção poderia de fato despersonalizar o ator... ${ }^{123}$

No que se refere ao teatro de convenção e estilizado em geral, então eu não posso de modo algum concordar nisso com o conferencista. $\mathrm{O}$ espetáculo de convenção (não apenas na minha opinião, mas isto sabem todos, ainda que tenham trabalhado pouco no teatro) não apenas não despersonaliza o ator, mas muito pelo contrário, apresenta demandas tão enormes a ele, quanto à personalidade, vivências tão profundas, que se torna extremamente difícil satisfazer as demandas dentro da escola teatral contemporânea.

$\mathrm{O}$ ator que é colocado tendo ao fundo a tela preta, no meio do imenso e vazio espaço do palco, é o único objeto, o único centro da atenção do público. Ele deve preencher todo este espaço apenas consigo, apenas com suas vivências, seu sangue deve aquecer este frio deserto.

Que concentração, que vivências profundas, que temperamento infinito é preciso para que sua atuação, além de transmitir os principais sentimentos da peça, faça também o público ver a floresta, o mar, escutar o seu barulho. E que incrível concentração e sinceridade é preciso para isto!

\footnotetext{
${ }^{123}$ Em sua conferência anterior, intitulada "Sobre o grande ator", A. P. Davídov teria afirmado que o teatro de convenção humilhava e despersonalizava o ator. (N. T)
} 
O menor enfraquecimento dos nervos aqui ameaça já ao tédio - uma coisa insuportável no teatro, visto que há muito já é sabido que toda arte é boa exceto a enfadonha.

E como o ator deve vivenciar o monólogo lírico neste tipo de encenação, sendo que até hoje, quando tudo na cena ajuda o ator, não existe para ele nada mais assustador do que o monólogo? Quando ao principiá-lo, o ator, inquieto, já começa a ouvir se o público tosse, ou assoa o nariz, ou está entediado?

E o que dizer sobre a destruição das mise-en-scene vivas, um dos principais procedimentos, que estimula e refresca a atenção do público, e que ajuda o ator a passar de um sentimento sincero a outro?

Em uma palavra, estou profundamente convencido de que por enquanto não há atores com esse tipo da individualidade forte, com esta vivência profunda, a qual é necessária tendo um fundo convencional.

É possível passar para um espetáculo mais primitivo encenado com um fundo preto e na superfície apenas através do ator, através do grande ator, através da escola de vivências e da imersão sincera, através do desenvolvimento da individualidade. É preciso passar com cautela, observando cuidadosamente para que o grau da convenção do espetáculo não esteja a frente do desenvolvimento do ator e por isso mesmo não o obrigue a forçar à sua criação o que logo e inevitavelmente será refletido na sua sinceridade da maneira mais lastimável. 
Tradução: Dos diários (1913-1914)

... Vulgaridade e grosseria: aí estão as duas coisas que mais me cansam. Mas somos obrigados a dar de encontro com elas diariamente e aguentar. Às vezes eu aguento; outras, isso passa a irritar de tal modo que não consigo mais suportar.

Entretanto, ainda não sei como é melhor lutar contra isso: se é preciso ter paciência ou chamar a atenção de vez em quando.

O melhor é um comportamento rigoroso e inacessível; só que isso é possível num banco, numa ferroviária ou numa frota, mas não na arte, não na arte teatral, onde é preciso alcançar uma alma alheia, revelá-la com cuidado, necessariamente apaixonar-se por ela e animá-la, quer dizer, revelar-se também a si mesmo.

Mas é exatamente aí que começa.

Se durante os ensaios fosse possível conviver com todos das doze em ponto até as quatro, e a partir das quatro horas e cinco minutos interromper tudo e se afastar, bem que seria fácil.

Mas após os ensaios restam entre as pessoas uns certos fios, pelos quais elas puxam seja lá o que for e como for.

Agarre-se exatamente nisso. E logo será preciso aguentar ou largar.

E tanto um quanto o outro são difíceis...

9 de dezembro de 1913

Da última vez em "A festa da paz", no final do segundo ato, uma dama do público entrou em histeria. Isso me desagradou. Em geral não gosto muito da histeria, ou seja, o que significa dizer que não gosto? Uma pessoa se agitando em histeria sempre dá pena, tal como alguém num ataque epilético, pois em ambas há uma doença nervosa que ademais se manifesta desagradavelmente, agindo diretamente sobre os nossos nervos; 
mas apesar de tudo, isso é uma doença nervosa, assim como há doenças de pele, que são igualmente antiestéticas e agem desagradavelmente sobre os nervos.

Só que na histeria é desagradável, sobretudo, não a doença em si, mas o fato de que a maioria dos histéricos se gaba de sua histeria e por isso não apenas não luta contra ela, como, pelo contrário, cede fácil e conscientemente, sobretudo em público.

Penso que isto acontece porque a histeria é vista como um indicador de abalo profundo da alma, uma demonstração de grandes vivências espirituais e do interessante, tênue e profundo mundo espiritual do ser humano.

Entretanto, isto é um erro gigantesco. Eu estou convencido de que nenhum homem ou mulher que esteja realmente sentindo algo profunda e delicadamente sofre de forma tão escandalosa. É possível ser extremamente rude e desagradável entrar em histeria todos os dias e pelos motivos mais insignificantes, especialmente se isto for em público; a propósito, por uma razão qualquer me parece que as pessoas sujeitas à tentação do ataque de nervos muito raramente entram em histeria quando solitárias.

No meio da massa, especialmente no teatro ou em qualquer outro lugar onde muita gente se reúne por um propósito assim chamado "ideológico", raramente o acontecimento se passa sem que haja histeria, pois basta que alguém não se contenha e grite a todos histericamente "Senhores, como é horrível; vejam como estou sentindo isso sutilmente; não consigo suportá-lo com a minha alma sensível", para que imediatamente os outros, fracos diante desta tentação, ecoem: "eu também estou sentindo sutilmente", "também tenho uma alma sensível".

É claro que a histeria pode ocorrer com pessoas fortes e profundas, mas isso é algo completamente diferente, se origina de outra forma e acontece de outra maneira e por outras razões.

A histeria é terrivelmente contagiosa e a cada ano que passa nessa nossa vida insensata ela se torna mais contagiosa, tanto psicologicamente - dos desejos mesquinhos e fúteis de chamar a atenção para si mesmo -, quanto fisicamente - das inverossímeis e insanas condições de vida, da falta de trabalho físico e de tudo aquilo, que tão irremediavelmente desmancha nossos nervos e abre terreno para todo tipo de doenças nervosas.

E é exatamente para este ponto, para o fato de que a histeria é sobretudo o resultado de uma doença dos nervos, que é importante que eu chame a atenção dos atores. 
Os atores amam imensamente quando há ataques de histeria no público; isto é considerado um certo tipo de evidência de uma interpretação extraordinariamente forte, de um entusiasmo profundo, de uma vivência sincera, etc.

"Hoje houve histeria duas vezes; como atuaram!" E, entretanto, me parece que a histeria do público prova exatamente o contrário.

Uma vez que a própria histeria é não o resultado de vivências profundas, mas uma demonstração da irritabilidade doentia dos nervos, dos órgãos dos sentidos, assim também as causas provocadoras da histeria se referem, não ao mundo espiritual ou moral, mas ao campo dos estímulos nervosos externos.

Quando um ator realmente vivencia algo, quando sua interpretação é uma "obra de arte", então por mais que ele deixe o espectador agitado, não haverá histeria. Eu me recordo de Duse e inclusive de Grasso e outros grandes atores, como Shaliápin ou Nikita, ou atores do Teatro de Arte nos melhores papéis e momentos, e não consigo me lembrar e nem mesmo imaginar que a arte deles provocasse a histeria. Pelo contrário, entregando-se à sua arte, até as pessoas com os nervos desconcertados e propensas à histeria vão tranquilizar a alma e alcançar a satisfação espiritual. Pode ser que chorem no espetáculo, mas estas lágrimas serão completamente diferentes: serão lágrimas não para o público, mas serenas e discretas, lágrimas nobres, de enternecimento diante do bem e da beleza, lágrimas pelas infelicidades e o pesar dos homens; até mesmo, talvez, pelo próprio pesar, já que eu também sou um homem e assim como os outros, estou sujeito aos sofrimentos; lágrimas deste tipo, pois somos todos infelizes, pois a vida é imperfeita, pois somos fracos no bem, pois amamos pouco uns aos outros e etc, porque o verdadeiro talento, a verdadeira arte, fala precisamente apenas sobre isso.

$\mathrm{O}$ ator contagia o público com aqueles sentimentos que ele próprio vivencia. E, independentemente da dimensão de seu talento, cada ator tem formas melhores e piores de agir sobre o público.

Quando em "A festa da Paz" viveram mais profundamente e vivenciaram as tarefas decorrentes da ideia central da peça, quando estas tarefas vieram do núcleo do papel, que nasce de um jeito ou de outro da ação transversal da peça (i.e. pessoas belas de alma se empenham no bem, mas não conseguem se dominar e sofrem profundamente com isto), estas tarefas tocaram notavelmente a plateia, tal como deve fazer a arte, e até em mim provocaram lágrimas, pois somos um tanto imperfeitos; cada um reconhecia a si mesmo e à própria alma nos personagens da peça, sofria tanto por eles quanto por si mesmo nesta luta contra suas paixões e defeitos, e se afligia, pois de uma forma ou de 
outra restava uma marca na essência do espetáculo: "Sim, nós somos assim, é uma pena para nós todos, mas o que poderíamos fazer para que fosse melhor? Ou não é possível melhorar? Hauptmann diz que não é, já que tudo depende da organização física e das condições externas, mas seria isto? etc. etc" As rodas da vida espiritual foram tocadas e o mecanismo da alma pôs-se a trabalhar...

Esta é uma influência nobre e aqui não houve nenhuma histeria, visto que os atores agiram sobre o público não por meio dos nervos, mas da alma.

Tecnicamente, no sentido de técnica interior, isto quer dizer que dentro do círculo, com os músculos relaxados, etc., o ator estava executando uma série inteira de tarefas decorrentes da ação transversal da peça, tarefas ligadas à ação transversal de seu papel, àquela essência do papel nascida da união da individualidade criadora do ator com a individualidade criadora do autor, expressa no cerne da peça.

Em seguida, gradualmente e a cada espetáculo, estas tarefas empalideceram e foram esquecidas pelo ator, restando na memória apenas formas através das quais as tarefas eram expressas, isto é, acumularam-se clichês exteriores, até um pouquinho mais tênues do que os exteriores. Restou na memória aquilo que agia sobre público - não os clichês musculares que se criaram, mas os nervosos -, as tarefas perderam o brilho e a irritabilidade nervosa aumentou.

O riso ficou mais forçado, as lágrimas, mais impetuosas, os gritos, mais intensos, os soluços e sufocos, mais barulhentos: os atores por si mesmos se excitam e irritam seus nervos; com estas sensações e estes nervos abalados e irritados, excitam e irritam os nervos do público, agora independentemente do motivo e finalidade destas lágrimas, riso, etc. Quanto ao autor, permanece apenas nas palavras, que se juntam a estes nervos irritados e apenas por isso é que se conhece o conteúdo - não o conteúdo, mas a fábula - , pois o público já está comovido e abalado, contagiado pelos nervos abalados dos atores.

Eis um exemplo de como estes nervos irritados agem sobre os nervos do espectador independentemente do conteúdo: em certa passagem uma atriz ri em cena e, tendo começado a rir, seu riso fere cada vez mais, chegando a tal ponto que uma espectadora sentada a meu lado entra em histeria coincidindo ritmicamente com os suspiros e as crises da atriz, até que os soluços são simultâneos e ela logo se esvairá num pranto histérico do mesmo modo que a atriz gargalhará histericamente.

Entretanto, na peça este riso é antes de tudo agradável e necessário ao autor, pois mostra que tudo deu certo e teve êxito exatamente enquanto a atriz executava uma tarefa relacionada à tarefa do autor; e foi assim. 
Mais um exemplo: um ator ri de modo feliz, mas também está tão satisfeito com este riso, o exalta tanto, gargalha tanto e com tal sinceridade - reparem que é com nervosismo e sinceridade -, que o público já não compreende e ouço cochichos: "Há histeria?"

Os atores se apaixonaram pelo próprio riso, pelas lágrimas e por seus próprios pavores mais do que por aquilo que originou tudo isso, aquilo que nasceu deles como artistas, e agora este espetáculo irrita os nervos com maior força, contagia lamentavelmente toda a plateia, mas contagia horrivelmente, penosamente, como uma histérica contagia outra. Isto significa irritar os nervos do espectador; isto é irritar os próprios nervos.

Quer dizer que sem qualquer razão, precisamente sem qualquer razão, sempre que alguém quiser será possível dar início ou forçar-se a dar início ao riso ou ao choro e assim conduzir-se à histeria? Como quiser. E se neste instante entrar na sala outra pessoa, será possível que ela não vá se contagiar com o seu riso e não vá começar a rir junto com você, igualmente sem qualquer razão, unicamente porque os nervos dela vibram sob a ação de seus nervos irritados?

A histeria é contagiosa.

Isso é precisamente o que acontece agora.

E aí está o porquê de eu não ter gostado deste ataque de nervos que nós tivemos no Estúdio. Este é um caminho perigoso. Um espetáculo assim pode ter um sucesso estrondoso, já que o público gosta, adora isso que chamamos de "forte impacto", assim como gosta da tourada, da luta, do teatro de horrores, dos terríveis exercícios com fogo e dos saltos perigosos para a vida: tudo aquilo que "abala" e, portanto, entretém sem aprofundar. Mas então o teatro deixa seu pedestal e fica no nível de tudo aquilo que é entretenimento...

A histeria no teatro, em obras dramáticas, é um indicador tão ruim para o ator quanto uma gargalhada animalesca do público em obras cômicas. Tanto uma quanto a outra são superficiais e de mau gosto. A ambas referem-se as palavras de Hamlet: "não permita que os jograis falem mais do que lhes foi indicado. Pois alguns deles costumam dar risadas pra fazer rir também uns tantos espectadores idiotas; ainda que, no mesmo momento, algum ponto básico da peça esteja merecendo a atenção geral. Isso é indigno e revela uma ambição lamentável por parte do imbecil que usa esse recurso." 
Como nós, orientadores, lutamos contra isso? Em primeiro lugar é preciso convencer os atores de que tal atuação é de mau gosto e de que este não pode ser o objetivo da arte. Contudo eu penso que só se eles entenderem isso é que vão desejar evitá-lo por si mesmos, visto que certamente é preciso antes de mais nada que eles próprios queiram fazê-lo. Agora, se isto não for feito por inteiro e o ator se agarrar pela metade naquilo que lhe dá um sucesso tão estrondoso, ainda mais quando ele percebe como age "com força" sobre a massa, será difícil desistir disso e então provavelmente ele não se corrigirá; ele não se corrigirá e isso significa que seguirá adiante por este caminho e no final das contas acontecerá que em seu próprio temperamento restarão apenas duas matizes: a gargalhada e o pranto, além de qualquer outro murmúrio trágico e horror, e então tudo será extremamente desagradável e repugnante.

Mas a tentação é terrivelmente grande e é difícil lutar contra ela. Eu realmente não acredito que nossos atores vivam apenas assim em cena, mas agora eles estão exatamente neste período de crescimento e por enquanto ainda não compreendem o que acontece com eles, embora já estejam indo por este caminho. Mais alguns espetáculos, e eles já ficarão terrivelmente estragados e então será ainda mais difícil trazê-los de volta.

É difícil ajudá-los principalmente por duas razões e eu não estou nem falando sobre sucesso, etc, mas simplesmente do ponto de vista técnico, pressupondo que eles compreendam isso e queiram se corrigir; é difícil, pois ao viverem em cena desta forma, o seu estado geral é ótimo; eles, como se diz, "viveram" sem extraordinário esforço, trocaram inclusive os mecanismos e contudo, não possuindo uma bússola na ação transversal, caíram naqueles mecanismos que de forma alguma podem ter lugar em determinada peça ou ato, mas não perceberam por causa disso, quer dizer, o estado geral estava ótimo, toda a face em lágrimas, o público foi aparentemente conquistado, e até demais - a histeria - , e o que mais querem de mim? Isso já são critiquices. E aqui cada crítica é recebida como uma ofensa injusta. "Pois eu não forcei a lágrima ou o riso: eles vieram facilmente até mim por si mesmos", eis a primeira razão; a segunda é que realmente no tempo de trabalho sobre o papel justamente estes sentimentos, este riso, este medo, etc. foram o objetivo no decorrer do semestre. Trabalhou-se precisamente apenas em cima disso, em chegar até estes sentimentos, e quando finalmente, por um caminho de trabalho obstinado e sofrido, o ator os encontra em si mesmo, não lhe é permitido vivenciá-los como ele gostaria. 
Ele se esquece de como foi sua procura, daquilo que o ajudou no trabalho, do fato de que tudo foi em busca das raízes dos sentimentos do autor e dos seus próprios sentimentos, bem como da união entre eles, se esquece de que estes sentimentos surgiram por si só quando chegou a hora, quando pelo caminho do aprofundamento em direção à sua própria alma criadora e à alma do autor nasceu ali, em algum lugar das profundezas, a união de ambas, e então vieram da alma aquelas tarefas que ao serem realizadas deram origem aos sentimentos; se lembra apenas de alguns de seus próprios sentimentos e de como eles se expressam. Até mesmo encontrando-os sinceramente esquece a sua finalidade e, tendo se apaixonado mais por seus sentimentos do que pela origem que tiveram, não dominando nenhum objetivo, exceto um, ou seja, como viver de forma mais clara com estes sentimentos, revolve-os, treme, provoca seus nervos e levando esta irritação nervosa até os limites físicos mais extremos, arruína os seus nervos e os dos outros além de distorcer o temperamento.

E é preciso dizer sem falta que sim, vocês estão "vivendo" sinceramente, com os nervos, em cenas agitadas, estão chorando e rindo com sinceridade, mas sem nenhum objetivo além de mostrar os próprios sentimentos; isto é, em princípio vocês provocam aquela mesma histeria e não criam.

Se concentrem o máximo possível, revivam em sua memória intelectual, sensorial e espiritual tudo aquilo que vocês viveram quando buscavam a si mesmos neste papel da peça. Isto é, em outras palavras, realizem todo o trabalho criador sobre a peça no início. Mas uma vez que este trabalho já tenha sido feito, então agora em vez de metade do ano neste trabalho, gasta-se um dia ou dois, e em seguida, antes de cada espetáculo, é preciso mais uma vez se incluir neste caminho, isto é, recordar a peça, o seu cerne, a sua ação transversal, o seu papel, o cerne do papel, a ação transversal, e então as tarefas e executar um após o outro: somente assim haverá a criação.

Me parece que existem dois tipos de esforços e clichês: o muscular e o nervoso.

O muscular é quando uma pessoa, sem sentir nada, tenta lembrar de cabeça como forçar a contração dos músculos que participam das manifestações deste ou de outro sentimento, tentando, desta forma, passar um sentimento. Alguns atores fazem isso com muita habilidade, muita semelhança e até mesmo com um interior absolutamente vazio; mas apesar de tudo, nós, isto é, nosso teatro, até mesmo os alunos, o reconhecemos e descobrimos com bastante facilidade.

Já o outro clichê é o nervoso, quando o ator encontra o sentimento vivo através da análise correta da peça, do núcleo, da ação transversal, através das tarefas, etc., isto é, 
encontrando o caminho tanto em si quanto nos sentimentos vivos e depois, gradualmente se esquecendo da razão de existirem estes sentimentos, o ator começa a viver apenas com os sentimentos, irritando os próprios nervos sensoriais através dos quais estes sentimentos passaram ao serem criados. Ele até é sincero nos próprios sentimentos, mas está sem objetivo e, portanto, é desnecessário em cena.

O primeiro clichê é possível sem qualquer trabalho sobre o papel, enquanto que o segundo se formará nos espetáculos. O primeiro me parece semelhante ao homem que arranca com as mãos uma flor da terra, para que ela cresça, arruma os botões com os dedos, etc., completamente esquecido das raízes. O segundo planta uma semente, cuida das raízes, rega e afofa a terra enquanto a flor não cresce. E quando ela cresce, então abandona gradualmente as raízes e dá toda a atenção para a flor; e para que ela fique mais bonita, começa a pintá-la com tintas a óleo; por causa disso as raízes secam ainda mais e as flores, por sua vez, também devido a isso empalidecem; então pintam-na ainda mais, toda a planta murcha completamente e o que resta é uma boneca morta, repugnante e borrada.

Mas onde está aquele que sempre irá tratar apenas das raízes e alcançará a exuberante florescência de toda a planta? Há poucos destes. Este é o destino dos grandes talentos. $\mathrm{Ou}$, em parte, daquelas pessoas que, embora não sejam extremamente talentosas, tem uma visão de mundo ampla e abrangente, para as quais nunca os próprios sentimentos, a força que possuem, a sua exibição para a multidão e, portanto, o seu engrandecimento diante dela, estará em primeiro plano e nem ofuscará a razão pela qual the é agradável e alegre vivenciar estes sentimentos em cena. Se Chátov, na cena de Chátov com Stavrognim, for interpretado não por um ator de talento excepcional, mas por um ator para quem existe a questão sobre Deus, sobre o seu culto e sobre o melhor cumprimento de seu próprio dever na terra, isto é, se estas questões não são alheias a ele e de uma ou outra maneira inquietam sua alma, esta cena será maravilhosamente representada, pois o ator nunca esquecerá a tarefa para a qual entrou em cena e seus sentimentos sempre surgirão desta tarefa, do cerne da peça e do papel, e apenas para a realização desta tarefa; e ele nunca abandonará esta tarefa e nem trocará este estado geral em cena pela demonstração dos seus próprios sentimentos ao público, pela demonstração de si próprio: "Vejam, dizem, como eu sou capaz, quão sensitivo e talentoso eu sou, como consigo emocionar vocês". 
Existem pouquíssimos talentos excepcionais, quase não há, a maioria está na média ou abaixo dela, mas há aptidões atraentes e agradáveis, das quais poderiam se formar bons atores.

Quer dizer, é impossível esperar que atores de talento mediano se relacionem com a arte da mesma forma que os talentos realmente excepcionais.

Também não é possível acrescentar talento. Ou seja, além da escola especializada - o "sistema" - , igualmente necessária tanto ao talento excepcional quanto ao mediano ("O 'sistema' é para os talentosos" - Stanislávski), há uma única maneira, um único meio de ajudar o talento mediano a se tornar um bom ator que trabalhe nas raízes da arte, a se tornar um artista verdadeiro, e não um representador de qualidades e características pessoais. Este meio é encontrar uma maneira de elevar e ampliar a visão de mundo, uma maneira de aprofundar o olhar sobre a vida e a relação com ela, desenvolver uma atitude mais ampla com relação às questões filosóficas, morais e sociais: trabalhar sobre a intuição em todas as esferas da alma e da natureza humana...

Mas como fazer isso e quem poderá fazê-lo?

E ainda pode surgir uma questão: não seria demais que houvesse muita razão na criação? Tanto no próprio "sistema" quanto inclusive nesta expansão e aprofundamento da visão de mundo?

Certamente, tudo o que for possível, tudo deve ser feito intuitivamente, mas nem todos estão dotados de intuição e além do mais, a própria intuição pode em grande parte ser estimulada e despertada através da razão.

"Do consciente ao inconsciente" como falou Konstantin Sergueivitch em seu "sistema".

$\mathrm{Na}$ inauguração do Estúdio Vladímir Ivanovitch falou sobre a intuição e isto alegrou minha alma. Eu sempre, a vida inteira odiei a razão quando ela se torna a dona, mas ela é uma ótima criada e é preciso saber servir-se dela.

É muito bom o que Tchekhov escreveu na quarta coletânea de cartas:

"Grigorovitch pensa que a razão pode superar o talento. Byron era inteligente como cem diabos, contudo foi o talento dele que sobreviveu. Se me disserem que $\mathrm{x}$ falou um disparate destes, que a inteligência dele superou o talento, ou o contrário, então eu direi: isto quer dizer que x não tinha nem inteligência nem talento." 
Hoje li Amiel ${ }^{124}$ : "Estudando nós aprendemos; contando, observamos; afirmando, seguimos; mostrando, enxergamos; e quando escrevemos, pensamos. Agitando a água, nós a atraímos para o próprio poço."

Frequentemente durante o trabalho eu pensava e até experimentava que se o ator não avançava em seu papel, deveria inflamar-se com ele, não a partir do diretor, mas colocando-se ele mesmo no lugar do diretor, isto é, mostrando como gostariaque este papel fosse feito; deveria contar a alguém sobre o seu papel. Frequentemente o diretor frustra todo o encanto e frescor do trabalho criador do ator, deixando-se arrebatar por seu papel, explicando-o muito e com fervor, mostrando-o, criando. Se faz isso mal, é simplesmente uma perda de tempo; se faz bem, o ator se vê privado da alegria da primeira união da sua alma com o papel e começa a copiar aquilo que o diretor conseguiu; e isto também é ruim, muito ruim.

$\mathrm{O}$ diretor precisa arder com as imagens e com a peça, mas ser paciente e compreender que antes de mais nada ele é um espelho - nisto está o essencial de sua destinação - , e todo o seu grau de saturação pelas imagens, o entusiasmo pela peça, o seu arrebatamento criador é nada mais do que um amálgama, graças ao qual ele pode ser um espelho, e não um vidro oco que não consegue refletir nada e portanto é inútil.

Novamente em Amiel: "Até que ponto são prejudiciais, contagiosos e doentios: o constante sorriso da crítica indiferente, esta zombaria insensível, que fere, examina e destrói tudo, que é decepcionante em cada obrigação pessoal, em cada afeição mortal e que valoriza apenas o entendimento e não a ação!

O criticismo, que se tornou um hábito, um modelo e um Sistema torna-se destrutivo para a força moral, a fé, quaisquer forças.

Esta espécie de inteligência é muito perigosa para nós, pois estimula todos os maus instintos, a indisciplina, o desrespeito e o individualismo egoista".

Como isto é verdadeiro! Como é preciso lembrar isto justamente no Estúdio, a todos os atores em geral, a todo aquele que trabalha na cena, a todas as pessoas, que participam numa criação coletiva. E como temos muito disso, mais precisamente entre a juventude. $\mathrm{E}$

\footnotetext{
${ }^{124}$ Henri-Frédéric Amiel (1821-1881). Poeta suíço pouco conhecido em vida. A glória veio para ele após a morte, quando teve seus diários publicados por amigos. Este fato é tido como um marco na mudança do tratamento para com os diários que com isso passaram a ser vistos como um gênero literário. (N. T.)
} 
o pior de tudo é que com esta característica da inteligência alguns ainda se exibem, vendo nisto algo positivo e que os distingue dos outros, uma certa posição privilegiada. Que erro fatal e deturpação de ideias sobre as características da alma do ator!

Assim intitularei um livro sobre a ética e a arte cênica: "Ao ator e ao diretor, a todo aquele que faz parte da massa, o maquiador, o aderecista, a cada um que vive para a cena ou trabalha nela. Ou de quem a vida passa em cena ou atrás dela". Mas pode ser apenas "Sobre a ética e a arte da cena", ou simplesmente o contrário: "Sobre a arte e a ética cênica".

Os pensamentos e observações são de Gógol, Shchepkin, Shakspeare, Tolstói, Stanislávski, Nemiróvitch-Dântchenko etc. Tchekhov e Chopin ${ }^{125}$.

Dividirei por partes - a técnica, as tarefas da arte cênica, os ideais - aqui estará tudo aquilo que eu lembro ter anotado de Vladímir Ivanovitch ${ }^{126}$, Konstantin Sergueievitch e meus pensamentos, e aquilo que anotei em meu trabalho com Vakhtângov e outros.

$\mathrm{Na}$ introdução será preciso dizer que isto é só um material, que não há equilibrio no livro e nem pode haver, pois é impossível trabalhar e anotar simultaneamente. Frequentemente se esquece o mais valioso, mas de qualquer modo com o tempo, todo este material incerto em combinação com outros esboços igualmente incertos e talvez trabalhos mais planejados e inteiros, conservará, apesar de tudo, ao menos algum rastro e a lembrança, senão de como criavam e daquilo que alcançou o Teatro de Arte, então ao menos daquilo que queria e para onde se dirigia, quais os seus ideais e como ele buscava seus caminhos para a conquista destes ideais.

A arte cênica - única da qual não resta qualquer lembrança -, não tem como permanecer já que seu único material é a palpitação (a pulsação) de um coração vivo em dado momento, o sentimento afetivo (afektivnoe chuvstvo) ${ }^{127}$, que nasce bem aqui, para o

\footnotetext{
${ }^{125}$ Sulerjítski refere-se ao escritor russo Nikolai Gogol (1809-1852); a Mikhail Shchepkin, célebre ator russo do século XIX; aos escritores William Shakspeare (1564-1616 ) e Lev Tolstói (1828-1910 ); aos diretores Stanislávski (1863-1938) e Dântchenko (1858-1943); provavelmente ao escritor russo Anton Tchekhov (1860-1904) - e não ao ator Mikhail Tchekhov - , e, por fim, ao pianista polonês Fréderic Chopin (1810-1849). (N.T.)

${ }^{126}$ Novamente Vladimir Ivánovitch Nemiróvitch-Dântchenko.

${ }^{127}$ A palavra russa chuvstvo tem mais de um significado, podendo referir-se tanto à sensação emocional quanto à sensação física. Stanislávski usa o verbo "sentir" (chuvstvovat) e seus derivados conscientemente, invocando tal multiplicidade, já que o Sistema do ator trabalha em todos os níveis (físico, emocional e
} 
espectador, que se inquieta, e que inquieta o coração do espectador, a sua transmissão imediata, de um coração a outro.

Morre o dono deste coração (o ator), morre o dono do outro coração que estava junto ao ator (o espectador), e não há nada além das palavras "O ator foi magnífico!" e de fotografias mortas - não resta nada.

Agora, se for possível conservar ao menos aquilo que entusiasmava o ator e o diretor, se for possível conservar, senão a sua própria criação e seus sonhos sobre criação, ao menos seus ideais e desejos, então só isso já poderá nos dar uma noção sobre quem foi tal artista.

Transmitir em cena imagens histéricas e almas tão esgotadas pelo fato de o ator esgotar os próprios nervos, interpretando a noite inteira em tom geral de esgotamento e contaminando o público com os seus nervos abalados, é uma técnica completamente errônea, de mau gosto, antiartística, que não dá alegria de criação nem ao ator nem ao espectador, ainda que esta técnica aja igualmente com força, mas aqui agem os nervos doentes do ator e não a percepção artística da imagem (é o ator que tem os nervos estragados e não o seu personagem).

A imagem de uma pessoa transtornada e histérica se atinge artisticamente assim como qualquer imagem, não pelo tom geral, mas por uma seleção adequada de tarefas, sua ordenação, o desenho correto do papel e na medida do possível, a partir das realizações sinceras de si neste desenho e de cada tarefa separada, situada na base de cada trecho separado, unidos pela ação transversal.

Então isto será arte, a qual, por mais que encarne imagens terríveis, sempre alegra e vive; do contrário, isto é uma clínica, o esfolamento da própria pele por influência.

$* * *$

22 de setembro de 1914

Ontem K. S [ Stanislávski] esteve a primeira vez no Estúdio, - estiveram reunidos todos os jovens para uma conversa sobre a populosa cena do baile de Fámussov. ${ }^{128}$

intelectual) ao mesmo tempo. Aqui, da mesma forma, a terminologia "sentimento afetivo", refere-se não apenas ao nível emocional, mas também ao físico. (N.T.)

${ }^{128}$ A juventude do Teatro de Arte estava ocupada com a cena do baile no terceiro ato de "A desgraça de ter inteligência" e no quarto ato, com a cena da partida das visitas. Em 1914 o espetáculo foi retomado para a cena do TAM. (N. ed. Russa) 
No final começou uma conversa sobre os exercícios do "Sistema". " Por que até agora não se formou uma classe regular e cotidiana, na qual seriam produzidos estes exercícios tanto por atores jovens, quanto pelos velhos atores?"

Eu sei: K. S. sonha que algum dia se estabelecerá uma classe assim, que toda a trupe do Teatro de Arte vai frequentar diariamente por meia hora, digamos, antes dos ensaios, ou entre eles, e onde exatamente estes exercícios serão praticados com rigor por todos segundo o "Sistema", como cantores executam vocalizos (comparação de K. S.) independentemente da parte que lhes cabe.

Os exercícios devem ser em separado:

- para o relaxamento dos músculos;

- para a introdução de si no círculo;

- para a afirmação de si mesmo na fé e na ingenuidade;

- para a habilidade de conduzir-se a si mesmo à qualquer estado afetivo (afektivnoe sostoianie) que seja, a habilidade de trazer para si aquela sensação que K. S. chama "eu sou"( ia est $)^{129}$ diante de diversas existências ou de alguns conjuntos de acasos, etc.

- para estabelecer o objeto vivo;

- para a estimulação em si do estado de prontidão para o trabalho por meio de todos estes caminhos, etc.

Além disso, todas essas tarefas devem ser atraentes, devem interessar a vontade $(\text { volia })^{130}$, pois conforme a expressão de K. S. que ele sempre verbaliza: "Não se pode mandar na vontade criadora - é possível apenas atraí-la."

Durante a reorganização das personagens em "A desgraça de ser inteligente" sua indicação para M. N. G. ${ }^{131}$ era: "não se ponham a negar uns e outros traços de seu personagem, não os expulsem à força; eles mesmos irão embora se vocês se interessarem

\footnotetext{
${ }^{129}$ Trata-se da sensação do ator de estar totalmente presente no momento dramático. Este termo funciona no "Sistema" como sinônimo para "vivênciar/experienciar e,na prática, todos os elementos do "Sistema" que relaxam o corpo e concentram a mente para a preparação do trabalho podem promover este estado chamado "eu sou". Uma vez que este termo tem como fonte o Yoga (no yoga "eu sou" é utilizado para definir a consciência que alguém tem de seu lugar na criação), seu uso no "Sistema" carrega conotações espirituais implícitas. (N.T.)

${ }^{130}$ No "Sistema", volia corresponde a um dos três iniciadores da vida psíquica e do processo criativo. O fato de "desejar", "ter vontade" de resolver o problema de determinada personagem é o que impulsiona o ator a entrar em ação. (N.T)

${ }^{131}$ EvidentementeM. N. Germanova, que estava interpretando o papel de Sofia em "A desgraça de ter inteligência”. (N.T.)
} 
por outras cores, que por si mesmas também ficarão no lugar das que lhes forem inúteis, pois vocês se apaixonarão mais por elas."

E eu ainda acrescentaria que talvez estas tarefas devessem ser ao mesmo tempo atraentes não apenas para o ator, mas também àquele que acompanha estes exercícios, o diretor ou o professor.

K. S. considera que enquanto estes vocalizos psicológicos ${ }^{132}$ - aliás, ele disse não "psicológicos [...]", mas vocalizos para a vontade, para a vontade criadora - não são realizados em tal ordem rígida e sistemática, até então não será possível considerar que a arte dramática tenha se tornado uma verdadeira arte e não diletante.

K. S. citou o exemplo de Dalcroze ${ }^{133}$, de como até uma pequena idéia é perfeitamente sistematizada e explorada.

Há muito tempo tenho dúvidas contra este ponto de vista, e quando conseguia dividi-las com K. S. num momento tranquilo, ele geralmente de uma forma ou de outra concordava comigo. Tenho algo contra a realização e o modo de empregar o Sistema como imagina K.S.

Possuindo uma experiência de seis anos, eu tentei ontem conversar sobre este assunto com K. S., mas em meio à tanta gente isto não saiu como eu gostaria. Tentarei fazer isto aqui.

Em um dos ensaios K. S. aconselhou: "Eis que agora vocês já acreditam nesta árvore, nestas passagens, já se revelam aqui, nestes cenários, mas ainda é muito necessário ensaiar, pois não estão claras as relações destes personagens. Eu aconselho: abandonem a cena, sentem em duas cadeiras (houve dois participantes) e ensaiem, mas deixem a cena em paz, do contrário irão banalizar seu estado geral cênico. Já não irão entusiasmá-los as atmosferas cênicas, as passagens, as árvores, etc. É preciso guardar isto sempre para que se conserve o frescor da influência da atmosfera cênica.

E ensaiem, agora sem a cena, tudo o que for necessário."

\footnotetext{
${ }^{132}$ Aqui a palavra utilizada foi dushevnie, a qual poderia também ser traduzida por "moral", "espiritual”, “da alma”. Uma vez que a ideia de psique russa compreende a ideia de alma, optou-se pela tradução "psicológicos”. (N.T.)

${ }^{133}$ Emile Jaques-Dalcroze (1865-1950), criador de um Sistema de educação musical inteiramente fundamentado em exercícios corporais e mundialmente difundido a partir da década de 1930. (N.T.)
} 
Stanislávski: Mas para que palavras? Sem palavras é possível transmitir com maior sutileza diferentes sentimentos. Por exemplo, que atriz transmitia em cena sentimentos mais exatos do que Dunkan? Se compararmos Dunkan e Duse ${ }^{134}$, então eu prefiro Dunkan. O teatro deve atingir esta arte até desenvolvê-la a tal ponto de transmitir tudo sem palavras.

Sulerjítski: Isto está completamente errado. O teatro do drama é aquele tipo dearte cênica, um meio no qual há não apenas os sentimentos, mas também os pensamentos, as ideias: e onde entram os pensamentos, onde o ator deve contagiar o público, reproduzir não apenas os sentimento, mas também os pensamentos, aí a palavra é imprescindível, e além disso, as palavras por si só juntamente com outras formas de expressão dos pensamentos e ideias que as auxiliam, possuem ao mesmo tempo a capacidade de serem belas, é possível aproveitá-las como matéria da arte, como se faz na poesia. Elas tem música, ritmo, estilo de língua do autor, etc, sem falar na voz, este delicado material para a arte. Se as palavras são rudes no palco,nisto os culpados são vocês, as pessoas do teatro, e não a palavra em si. Isto quer dizer que vocês ainda não encontraram um modo de pronunciar as palavras, expressar os sentimentos e pensamentos com as palavras.

Os atores semprecompreenderam o teatro dramático como uma arena, onde eles competiam em representações de sentimentos. E nesta esfera havia grandes atores, que sabiam sentir a beleza e a força dos sentimentos e recorriam às palavras, já que elas davam a possibilidade de representar os sentimentos. Vivenciar os sentimentos - bem ou melhor - muitos conseguiam, mas vivenciar os pensamentos juntamente com os sentimentos, sentindo já neste momento toda a beleza da língua da obra e a beleza da palavra, disso ainda ninguem é capaz. Isso, eu afirmo, ainda não foi tocado, não se vive ainda pela beleza do próprio pensamento.

Eis que este deve ser o próximo degrau no desenvolvimento do teatro dramático. E é maravilhoso que ele não tenha sido encontrado, pois os atores ainda não sabem, como pronunciar as palavras de forma bela, para que elas expressem não apenas o sentimento, mas também o pensamento - viver não apenas com os sentimentos, mas também com a ideia, o pensamento das obras (exemplos; "Brand", "Rosmersholm"). ${ }^{135}$ É necessário

\footnotetext{
${ }^{134}$ A bailarina americana Isadora Dunkan (1877-1927) e Eleonora Duse (1858-1924), uma das principais atrizes européias de fins do século XIX e início do XX. (N.T)

135 "Brand" e "Rosmersholm": peças de H. Ibsen. "Brand" foi mostrada pela primeira vez pelo Teatro de Arte em 20 de dezembro de 1906 com V. I. Katchálov no papel principal. «Rosmersholm" foi encenada por Vl. I. NemiróvitchDântchenko em 1908 e por E. B. Vakhtângovem 1918 no Primeiro Estúdio do TAM. (N. ed. Russa)
} 
encontrar o que o ator precisa estudar para que ele possa se entusiasmar com as ideias da obra, tal como encontrou Dunkan o que precisava estudar para a sua própria arte. Talvez o ator precise estudar os pensamentos, as ideias, conhecê-los melhor do que os atores habitualmente os conhecem; além disso, talvez, seja preciso possuir para esta arte alguma qualidade extraordinária, mas dizer que as palavras são grosseiras, é errôneo, é que simplesmente os atores ainda não alcançaram as tarefas. Aqui algo ainda não foi encontrado e o Sistema de K. S. é o Sistema para a vivência correta dos sentimentos. E nesta esfera este é o último ponto do desenvolvimento da arte cênica como a arte da vivência, este é o último ponto encontrado no desenvolvimento do teatro dos sentimentos. Com isso termina um período inteiro da vida do teatro. O máximo desenvolvimento do teatro como o teatro dos sentimentos - Grasso e Stanislávski (intuitivo e dedutivo).

Neste período o pensamento (a ideia), sempre esteve na cena na medida em que ele não podia não revelar-se por si mesmo, e frequentemente o ofuscavam e atrapalhavam completamente, desenvolvendo os sentimentos de sua maneira, independentemente do pensamento. Lembrem as palavra de Stanislávski: desenvolva em si este sentimento, mas as palavras o autor é quem dirá.

Agora o desenvolvimento do teatro deve ir em frente na direção à reprodução por meio de sentimentos, os quais na cena já não serão os mesmos para si, não o único objetivo, mas um meio em direção à reprodução das ideias.

Isto ainda não foi encontrado. E que no teatro haja uma tendência (Craig/ Stanislávski) a privá-lo de suas palavras, mostra-me apenas o vazio de nossa vida. Eu estou convencido de que este desejo de um teatro sem palavras - teatro da beleza externa (como se não houvesse a beleza de uma ideia, a beleza do pensamento, a beleza da palavra, do som) depende do espirito da época.

A beleza do pensamento e das ideias é a maior beleza, o maior tipo de arte, e que ela é possível apenas através das palavras, que as ideias e pensamentos podem ser matéria da mais elevada arte, isto nos provam Byron, Tolstói, Dickens, etc. Na literatura vemos isso - é preciso encontrar isto na cena.

Que as palavras atrapalham ao expressar um sentimento ou ideia, isto é como se Dunkan dissesse: as danças, os movimentos com as pernas no balé me atrapalham ao transmitir minhas sensações, e por isso renunciasse aos gestos e poses. No entanto, ela não fez isso, pois justamente isto também é matéria de sua arte. Ela desistiu de "tais gestos" e 
encontrou novos, próprios, encontrou um novo modo para o gesto e movimento. Ela estudou o gesto e a pose em Botticelli na antiga escultura e etc e encontrou.

Me perguntam: "Para onde então pode este teatro, o teatro das palavras, desenvolver-se adiante? Ele já atingiu o apogeu". Me lembro da bailarina que também podia dizer para à exigência de Dunkan, que o balé já não pode se desenvolver mais, que é impossível movimentar as pernas mais rápido, que não dá para ficar mais tempo nas pontas dos pés. Entretanto Dunkan mostrou que é possível. Ela impulsionou adiante justamente este tipo de arte, conservando todos os seus elementos básicos.

É o mesmo no nosso caso, que o teatro de Arte é apenas o primeiro degrau desta montanha. E também seria necessário alguma Dunkan que movesse adiante justamente esta arte e não outra. É possível também criar outra arte, mas isto seria um erro - não é preciso dizer que o teatro sem palavras éuma ideia de desenvolvimento do teatro. Será possível dizer que sem palavras pode ser mais fácil transmitir pensamentos e ideias? Isso é um erro completo. O monólogo "Ser ou não ser" pode ser dito apenas com palavras.

A beleza dos pensamentos e ideias, quase não se compreende. O pensamento é perigoso e quanto mais talentoso o pensamento, maior o perigo. E quanto mais bonito, tanto pior. Não querem seguir o pensamento, tem medo dele. Em nossa vida cheia de contradições, baseada na mentira e no engano, nas impressionantes cegueira ecrueldade, não podemos nos deleitar com as belezas do pensamento e da ideia, pois a beleza da ideia é a realidade, a verdade. E nossa vida inteira se passa precisamente nisto: em escondermos a verdade de nós mesmos o mais longe possível. Nunca ela foi tão intolerável quanto agora. Não se pode sentar e deleitar-se com as belezas da realidade, da verdade, quando nós sabemos, nós nos esforçamos em não saber, fingimos que não sabemos, mas mentimos uns aos outros, e mentir para si é difícil, nós não somos tão obtusos quanto os antigos gregos.

Quando nós sabemos que nossas vidas custam vidas de centenas de milhares de pessoas, que nós tiramos o leite de crianças, queseparamos famílias, expulsamos as moças para se venderem a nossos filhos, que nós com nossa vida - sim, sim, tudo isso nós sabemos - tiramos da imensa maioria das pessoas a última sanfona, sufocamos a canção com o estrépito dos carros nas fábricas, onde obrigamos as pessoas a trabalharem para nós, as privamos não apenas do pão, da terra, mas também do céu, e nós sabemos disso tudo. E perto, bem aqui, perto de nós, ombro a ombro, nossos obreiros, os cocheiros, os 
mendigos, as crianças, que importunam com pedidos de copeques - será possível não ver tudo isso? Realmente todos mutilados pelas fábricas e a cidade cuidadosamente somem da nossa vista, nós nos protegemos de todos os lados, mas infelizmente, não conseguimos - nós quase não vemos- mas sabemos.

Nós já não somos tão primitivos para, escondida a cabeça como um avestruz, pensar que não há para ele nada de ruim, já que ele não vê e nem somos tão toscos e cruéis como os antigos gregos ou até mesmo nossos avós - escravistas - oh, nós somos delicados, muito delicados!

Quanto mais nos opomos, mais a verdade flui e flui, melhorando-nos, apesar de toda a nossa resistência.

Como então o teatro pode se tornar um templo?

Ele é como em "Brand" - vem para cá escutar, como a voz do orador ora se ergue, ora se silencia com doce tormento etc. De templo, o teatro se transforma em diversão.

O Teatro de Arte está no limite: ele elabora em seu próprio interior uma atitude para consigo mesmo, como em direção a um templo, e por isso começa por si só a chegar perto da verdade e passa a temê-la, recuar, oscilar juntamente com toda a arte e o seu desenvolvimento tal como disse Tolstói: O talento é dotado de uma qualidade especialque leva à verdade.

E agora é terrível: ir ou voltar?

Não desviem: busquem!

De qualquer forma a qualidade especial virá e a questão está apenas nisso: vocês virão com os primeiros ou com os últimos.

Virão por si só ou serão trazidos.

Até agora ninguem teve pena de ir em busca da verdade.

(Sem data)

No caminho do ator dramático a imensa maioria ingressa ou de fato sentindo em si capacidade para esta arte ou imaginando que a tem. Mas qual o objetivoe porque tal multidão se esforça para a cena? Em que consiste esta capacidade?

Esta é a qualidade especial do homem talentoso, que possui talento dramático ou os assim chamados sentimentos afetivos, isto é, a qualidade especial de chorar, rir, invejar, horrorizar-se, etc. Viver com diferentes sentimentos em público não pelas razões existentes, mas apenas pelos motivos imaginados, sugeridos a ele pelo autor da peça, a 
quem ele interpreta, ou pela própria fantasia que estará criando a ele uma ou outra medida para estes sentimentos, em uma ou em outra ordem, a qual ele precisará para seu objetivo. A essência desta arte está naquilo que estes sentimentos necessariamente comunicam segundo o grau do talento do intérprete - ao espectador e o agitam assim como se ele mesmo vivenciasse isso tudo.

Os espectadores juntamente com o interprete, choram, riem, se horrorizam. Dizem: "Como ele prendeu a plateia"; "Ele comoveu os espectadores"; "Toda a sala como uma ergueu-se junto a Moltchálov"136.

"Hoje estão chorando sem cessar"- e não há para o ator alegria maior do que olhar pela fendinha como na sala de espetáculos aparecem lenços brancos e se ouve o assoar de narizes após a sua cena.

E eis que estepoder sobre os espectadores, eis que consciência de que" eu fiz a platéia chorar, rir, tremer de medo", esta demonstração das qualidades especiais da própria alma, como num circo se demonstra a liberdade de seu próprio corpo, somado a este poder sobre as almas dos outros, constituem a principal sedução e encanto da cena...

E eis porque os artistas de circo que representam independentemente de sua sinceridade - quer dizer, do talento - nomeavam os comediantes, perfeitamente com justeza ligando-ossubstancialmente às pessoas que divertem seu próprio corpo ou alma. Além do mais, reparem que em relação aos acrobatas sempre se referiam mais brandamente do que aos atores. Faz pouco tempo que o ator livrou-se do desprezo, e foi algo muito pequeno, mas antes que ele alcance a condição de sacerdote, e o teatro, a condição de templo, ainda será preciso fazer muito, muitíssimo, e disso trataremos adiante...

Quando um ideal for atingido, então será enfadonho... Por que vocês pensam que quando este ideal for atingido, então não haverá outro mais alto do que este?

Este é um ideal, pois nós não podemos imaginar nada mais alto do que isso neste nosso estado.

Uma perfeição sem fim.

Não se pode tão imprudentemente pegar nas mãos uma arma tão poderosa quanto a arte e tratar dela com tamanha imprudência, não conhecendo suas forças, em prol de seus interesses, do êxito ou das vantagens que ela traz.

\footnotetext{
${ }^{136}$ Provavelmente Pavel Stepanovitch Moltchálov (1800 -1848), importante ator russo do Teatro Mali.
} 


\section{Trechos originais:}

\section{1) página10}

За кулисами театра усиленно заговорили о Сулере: «Милый Сулер!», «Веселый Сулер!», «Сулер революционер, толстовец, духобор», «Сулер - беллетрист, певец, художник», «Сулер - капитан, рыбак, бродяга, американец!»

\section{2) página12}

(...) se origina la pertenencia del yo a su mundo, que a su vez, revela la experiencia subjetiva.

\section{3) página12}

Con todas sus ambiguedades, el cosmos personal del escritor/a de diarios intimos, fluctuando entre la experiencia temporal del dia a dia, es anotado en el diario en un acto de escritura - y de conciencia de sí por el que nos comunica y pone en contacto con su mundo. Un mundo en el que tambien están presentes $\operatorname{los}$ otros $(\ldots) "$

\section{4) página 18}

Впрочем, учителем жизни более, чем учителем сцены.

\section{5) página22}

...природа Сулера была сложна и многогранна, и он был художник, литератор, певец, актер, администратор, немного музыкант, и он отлично чувствовал пластику и танцы, интересовался философией, любил психологию и проч. и проч. Добавьте к этому исключительно хороший вкус, большой темперамент, огромную трудоспособность, и станет ясно, почему Сулер так быстро вырос в настоящего режиссера и сценического деятеля.

\section{6) página23}

Осень 1900 года в Москве. Театр наш (тогда еще не МХАТ, а Художественно-общедоступный) репетирует "Снегурочку". (...). И вот, помню, в одно прекрасное утро, именно прекрасное осеннее утро, опаздывая на репетицию, бегу по Бронной. Меня обгоняют три фигуры: все разного роста, все по-разному, все необычно одеты, двое повыше ростом, третий низенький и коренастый. Все трое вбежали в подъезд “Романовки”. Вхожу за ними и вижу растерянные лица, слышу недоумевающие голоса - куда дальше идти, кого спросить?

Самый маленький, одетый в матроску, без шапки, с коротко остриженной головой, с окладистой бородой, казался на вид старше остальных. Он уставился на меня смеющимися, лукавыми, прищуренными глазами и спросил высоким певучим тенорком, с ярким киевским акцентом: “Будьте таким ласковым, скажите, пожалуйста, вы не хосподин артист будете?” - и объяснил, что им всем очень хочется попасть на репетицию. Я, помню, что-то пробормотал, что это от меня не зависит, что я очень спешу, опоздал, впрочем, спрошу или пришлю кого-нибудь из администрации. Оказалось дальше, что еще не все собрались, что я не опоздал, и я сейчас же спустился опять к ним, очевидно потому, что эти три фигуры меня заинтересовали.

Начался разговор. Говорил самый высокий из них, приятным баритоном, с легкой хрипотцой, часто откашливаясь. Говорил очень на "о" - о том, что им хочется бывать на репетициях, что их сам Немирович приглашал, еще весной в Ялте, всегда бывать в театре, когда они будут в Москве. “Это ж Горький, - отрекомендовал его маленький с веселым смехом, - фамилия его такая. Горький, Максим Горький, писатель. И хороший писатель. Молодой еще, но уже хорошие рассказы пишет. А этот, - он указал на второго, - поэт, Скиталец фамилия, имеет большой голос - бас и на гуслях играет. А я - тоже вроде писатель. Еще ничего не написал, но буду писать обязательно. Моя фамилия Сулержицкий, а короче я Сулер. Выходит у меня похоже на "шулер", но это потому, что у меня одного зуба спереди не хватает..."

\section{7) página24}

Своей игрой Вы на несколько часов соединили всех разобщенных холодным эгоизмом жизни людей в одно целое, дали возможность вздохнуть несколько мгновений свободным воздухом добрых, 
любовных, братских отношений людских друг к другу, без которых все так жестоко страдают в жизни, но которых установить между собою люди еще не могут по своей слабости и непониманию.

\section{8) página24}

(...) как великая школа жизни, как зеркало, отображающее жизнь и помогающее преобразовать ее.

\section{9) página 24}

Он - «мудрый ребенок», по определению Толстого, — включил театр в свою жизнь, как ранее включил поездку к духоборам, отказ от воинской повинности, долгую службу матросом, и полюбил его так, как любил жизнь, соленую воду, море, а в особенности - человека.

\section{0) página 25}

(...) при первой возможности я куплю обетованную землю в Каневе, Киевской губернии, брошу все и уйду к природе. Но пока надо жить и работать для этой цели и для семьи. Лучше всего работать для искусства, в театре, у вас. Тут можно общаться с живыми людьми и чувствами сказать им то, чего не скажешь словами»

\section{1) página 25}

Я верил в Сулера, охотно принял его предложение взять его себе в помощники и не ошибся. Его роль и значение в театре и искусстве оказались большими.

\section{2) página26-7}

Итак, во Флоренцию мне ехать нельзя. Где же нам свидеться с Крэгом? В Канн, но там сезон и очень дорого. В Берлине. Это было бы самое лучшее, и вот почему. В Дрездене существует школа пластики и ритмических танцев Далькроза. Я туда поеду, так как говорят, что это удивительно. Это должно быть интересно и Крэгу. Сделаем так. В один и тот же день мы выезжаем из Канн или другого места, а Крэг из Парижа, съезжаемся в Берлине и едем в Дрезден. Тем временем переговорим о том немногом, о чем нам надо переговорить, то есть:

- Разрешает ли он искать расстановки ширм на самой сцене, ища общего настроения, а не придерживаясь пунктуально его макетов.

- Разрешает ли он, сохранив общий замысел короля, двора, Офелии, Лаэрта, то есть их карикатурность, изобразить или подать публике в несколько иной форме, то есть более утонченной и потому менее наивной. Вы понимаете, что поданный «Гамлет» в том виде, в каком хочет Крэг, опасен. Его (то есть не самого Гамлета, который великолепен у Крэга, а трактовку других ролей) не примет Москва в том виде, в каком ее передает Крэг. Надо сделать то же, что Крэг, то есть короля - ирода, варвара, бессмысленный двор с его нелепым этикетом, и Офелию, и Лаэрта — детьми своей среды, но только надо показать это не теми марионеточными приемами, какими делает их Крэг. Собственно говоря, вот и все, о чем пока мне надо говорить с ним, остальное относится к простому желанию видеть его и условиться относительно его приезда в Москву.

\section{3) página 27}

Дорогой Константин Сергеевич,

был у Крэга и вот что выяснил: в Дрезден он ехать не хочет, он говорит, что ритмические танцы его не интересуют, и думает, что и Вам это не покажется интересным. Поэтому не хочет ехать и в Берлин, который он ненавидит. Предлагает, чтобы Вы вызвали его телеграммой в Канн, и он тотчас же приедет туда.

Итак, встретиться с Вами теперь он хочет в Канне или на Капри (смотря по тому, где Вы будете), и куда Вы должны его вызвать телеграммой.

На все Ваши вопросы по отношению к постановке «Гамлета» и трактовке ролей отвечает, что во всем этом он доверяет Вам, что как это сделать, чтобы было хорошо, Вы знаете лучше его. Поэтому делайте, как найдете лучше.

Приехать в Москву ему кажется лучше в мае.

Вот ответы на Ваши вопросы.

По правде сказать, относительно его приезда в мае я тоже высказал свое мнение, — я думаю, что лучше, чтобы он приехал попозже, когда хоть что-нибудь будет найдено. Иначе он будет тормозить работу и выдумывать ширмы из бронзы, из дуба и так далее.

Не ездите к Горькому. То есть, если мимоездом заглянете - это было бы очень хорошо. Но не останавливайтесь у него. Это будет Вам очень утомительно. Он, как почти все эмигранты, страшно много говорит, и заговорит Вас насмерть.

Простите, что вмешиваюсь в Ваши распорядки, но знаю, что это Вас утомит и Вы не 
отдохнете, а устанете. А вот если бы заехали дня на два к нему 一 это было бы хорошо для театра, я думаю. Авось пьеса какая-нибудь особенная родилась бы.

\section{4) página27-8}

Крэга еще не отчитывал. Он в ужасно бедственном положении. Занял у меня вчера 20 франков, так как нет ни гроша. Куда он девал все эти деньги? Если бы я получил столько, я уже жил бы у себя на даче и работал бы в театре, как меценат. Однако денег у него нет, и он просил меня телеграфировать Вам, чтобы ему хоть что-нибудь выслали из театра. (...)

Сейчас пришел Крэг и говорит, что он был бы гораздо более доволен, если бы взяли его на такой-то срок, кончили работу, заплатили, и конец.

А то растянули работу на бесконечный срок, меняют сроки его приезда, и он сам не знает, когда он будет нужен. И, конечно, он был бы гораздо более доволен иметь годовое условие. Теперь его семья уже две недели не имеет ни гроша. Он сам тоже. Нет никакого подписанного контракта, который подписал бы он и театр; он ничего не имеет против этого, пока театр не меняет своих обещаний, но театр постоянно меняет!!

Вот его слова! Черт его, путаника, разберет. Но видно, он в большой нужде и живет только тем, что получает от нас. И тотчас же пропускает, вероятно, на свою «Маску» и на всякие свои изобретения.

Я на месте театра такого художника не бросил бы без помощи, но следил бы за ним, как за Горевым 315 . Посылал бы ему понемногу денег, но почаще. Потому что, сколько ему ни пошли, он спустит все. Его надо поддерживать все время, а не платить.

Сейчас сидит у меня на стуле, в круглой шляпе, трет подбородок, смотрит в потолок, под мышкой пергаментная книжка, в которой зарисована новая система, которую он покажет только Вам, и палка с костяным набалдашником - морщит брови, трет себя по подбородку и не знает, как ему быть, что говорить, куда телеграфировать и вообще что делать.

Несчастная, потерянная фигура, все-таки возбуждающая во мне умиление и улыбку.

Надо его поддержать. Так я знаю сейчас по чувству. Что же делать, если он все-таки ребенок, в конце концов, и художник? Никакие контракты с ним невозможны, и вся деловая сторона всегда будет с ним в беспорядке. А все-таки надо его как-то поддерживать. Вот мое мнение.

\section{5) página 29}

Милый Лев Антонович!

Сегодня Вы не были в театре, вчера не поехали к нам...

Или Вы захворали, и тогда напишите словечко о состоянии здоровья, или Вы демонстративно протестуете и сердитесь, и тогда мне становится грустно, что работа, начатая радостно, кончается так грустно 330 .

Когда я стою перед такими догадками, я чувствую себя глупым и ничего не понимаю. Чувствую, что мне надо что-то сделать, что-то понять, и не знаю и не понимаю, что происходит. Вы рассердились на Крэга за перемену освещения? Не верю и не понимаю. Ведь декорацию и идею создавал Крэг... Казалось бы, ему лучше знать, что ему мерещилось... Как смешон Ганзен, считающий «Бранда» своим произведением 331 , так был бы смешон и я, принимая ширмы и идею постановки «Гамлета» за свое творение. Победителей не судят, а ведь «Мышеловка» имела вчера наибольший успе ${ }^{332}$.

Кроме того. Разве Вы не почувствовали третьего дня, когда Качалов пробовал играть в темноте, только что установленной Крэгом, что в ней-то (то есть в темноте) и спасение всего спектакля. И действительно, вчера темнота закрыла все недоделанное. И боже, как выступили недостатки Болеславского $\underset{333}{\longrightarrow}$ когда свет осветил его всеми рефлекторами! И последняя картина сошла именно потому, что свет скрыл всю оперность костюмов.

Есть предположение, что Вы обиделись за афишу. Но причем же я?

Крэг закапризничал, отверг все предложения. Театр требует, чтобы было имя Крэга, так как сделанный им скандал стал известен в городе. Крэг требует на афишу мою фамилию, так как боится ответственности и запасается мной, как козлом отпущения. Среди всех этих хитросплетений я должен примирить Крэга с Вами или Вас - с Крэгом, так как не могу стоять один на афише. Я ничего не соображаю в такие минуты. Иду за советом к Вам, а Вы мне говорите о «Синей птице». И я уже тогда ничего не понимаю. Неужели этим закончится так хорошо, дружно начатая работа? Если да - тогда надо бросать лучшее, что есть в жизни, - искусство и бежать из его храма, где нельзя больше дышать.

Нельзя же жить, жить - и вдруг обидеться, не объяснив причины. Что Вы обижены на Крэга — понимаю, хоть и жалею. Но... Крэг большой художник, наш гость, и в Европе сейчас следят за тем, как мы примем его творчество. Не хочется конфузиться, а учить Крэга - право, неохота. Не 
лучше ли докончить начатое, тем более что остался всего один день.

Смените гнев на милость и не портите хорошего начала дурным концом.

Завтра в два часа устанавливаем появление призрака в спальне $\stackrel{334}{.}$

Обнимаю Вас.

К. Алексеев.

16) página29- 32

23 декабря 1911 г.

Москва Дорогой Константин Сергеевич!

Крэг - большой художник, и таким для меня и остается и останется навсегда. Что он гость наш, я тоже знаю и, кажется, в течение двух лет работы с ним доказал, что умею терпеть и грубость, и раздражительность, и путаницу этого человека и, несмотря на это, искренно любить его.

Что за ним следит Европа, мне решительно все равно, от этого мое отношение ни к нему, ни к кому бы то ни было измениться не может.

Освещать он может, как ему угодно, - это его право, и я ничего не имею против этого, и помогал ему, и буду сегодня работать над освещением «Спальни», потому что в спектакле, как и во всей пьесе, не одни ширмы, а есть и Ваша, и моя работа, и работа театра, и раз нужно что-то переделать, то буду переделывать, раз этого хочет главный режиссер пьесы - Вы.

Да и пока не окончен «Гамлет», я готов выполнять задания Крэга, даже если они и не сходятся с моими мнениями, раз только Вы находите, что Крэг прав.

В области художественной работы я не могу быть обиженным - Вы это знаете очень хорошо, и знаете почему: потому что уж слишком мало я верю в себя и свои силы, тем более когда имею дело с Вами, - это было бы смешно и глупо.

Не совсем так с Крэгом.

Когда он говорит о линиях, рисунке композиции и даже освещении, я чувствую, что это Крэг, но когда вопрос касается режиссуры, то тут я не уверен, может ли он быть безусловно прав слишком мало он интересуется актером.

И с этой точки зрения нахожу, что «Мышеловка» освещена неудачно, и если она имела успех на генеральной, то не благодаря освещению, а несмотря на это освещение. Все жаловались, что не видят Гамлета, а публика первого представления этого не простит театру.

Но и эта перемена меня нисколько не обижает и не может обидеть. Я могу жалеть, что это освещение повредит спектаклю и Качалову, но отнюдь не обижаться, так как, опять-таки мало веря в себя, легко согласен думать, что ошибаюсь, хотя мне обидно, что Вы так скоро уступили мнению всех, так как сами спорили с Крэгом минут десять о том, что в такой темноте играть нельзя, что ширмам хорошо, а актерам и спектаклю плохо.

Но повторяю — и тут нет никакой обиды.

Крэг не захотел, чтобы я был на афише - после двух лет тяжелого труда, после многих, скажу, жертв Крэгу, сознавая, что без меня вряд ли у нас в театре удалось бы ему довести свое дело хотя бы до такого конца, - это для меня неожиданно.

И только.

Но не обидно.

Крэг-художник для меня остался, Крэг-друг совершенно пропал - навсегда.

Этот тип англичан мне хорошо известен за время моей деятельности в Англии и Америке.

Ничего общего между мной и им быть не может и поэтому не будет. Тут нет никакой обиды, но дела с ним никакого никогда я иметь не буду - просто не интересно иметь дело с таким человеком, вот и все.

А работу его, что бы то ни было, я с наслаждением буду смотреть, как всегда.

Единственно, где за все это время у меня было чувство мгновенной обиды, довольно острой, это когда Вы стали спрашивать меня, как быть со мной, что Крэг, мол, не хочет, чтобы я был на афишах.

Обидно было то, что на днях не я (я иначе думаю), но Вы сами говорили, что меня надо поставить на афише, так как, по Вашему мнению, для меня это важно, ввиду того, что я работаю на стороне.

Но стоило Крэгу, не Крэгу-художнику, а Крэгу-авантюристу, наглому дельцу, который в нем сидит и каким он является в этой истории, этого захотеть, и Вы, считая, что он несправедлив ко мне, и думая, что мне это важно, готовы тотчас же, немедленно отдать меня ему, да еще меня же самого об этом спрашиваете.

Я невольно вспоминал, как всегда, где я имел право, но где надо было меня отстоять, Вы при малейшем натиске со стороны, или даже от одной возможности натиска, немедленно готовы были отдать и меня и мои не только мнимые, как в данном случае, но и настоящие интересы. 
И всегда отдавали.

А между тем я вижу, что с другими своими друзьями Вы умеете сделать так, и крепко сделать, чтобы их интересы не страдали несправедливо.

И когда все это вместе вспомнится, как вспомнилось последний раз, то становится очень обидно, и возникает вопрос - правильно ли стоят наши хорошие отношения?

Очень скоро это забывается, но след от каждого такого случая невольно остается в душе и на моем отношении к Вам проводит легкую царапину.

И только.

Обида была, я чувствовал ее несколько часов, а потом она прошла, и конец.

Вы говорите - надо хорошо кончать то, что хорошо начато. Об этом надо сказать не мне, а Крэгу и Вам.

В заключение: на Крэга я не обижен за его поступок, но люди, способные на это, мне не интересны — это не моя

компания, я просто избегаю встреч с такими людьми и вовсе не собираюсь их ни учить, ни перевоспитывать, - их слишком много, - просто избегаю, они мне скучны и неприятны.

А на Вас, ей-богу, не обижен - это не в первый и не в последний раз.

Так будет всегда.

Нет во мне чего-то такого, что мешало бы так относиться ко мне, тем более что Вы даже не замечаете таких случаев.

Сделать тут ничего нельзя.

А если наберется слишком много таких царапин, так много, что они сольются в одно целое, тогда, вероятно, наши хорошие отношения остынут.

Но жизнь коротка, а такие случаи не часты, так что места для царапин хватит с избытком, и, значит, все идет по-старому.

Обнимаю Вас.

Ваш Сулержицкий

\section{7) página 32}

Мы спросили в Студии, как успела отразиться война на оценке художественных произведений и на очередных задачах искусства.

Война - был ответ - с особой остротой выдвигает очередные задачи искусства. Становится все более настоятельной задачей прилагать все усилия к осуществлению основной цели искусства - будить в человеке человеческое.

Этот принцип и руководит всеми работами Студии.

В искании формы главное внимание режиссеров Студии обращено на выражение идеи. В этом году, как и в прошлом, при выборе пьес, при постановках и репетициях мы старались найти и выдвинуть все то, что объединяет людей, что говорит о той человечности, которая свидетельствует о божественном начале в человеке.

Из этих поисков человечности, теплоты логически вытекает репертуар сезона. Так, первая постановка - возобновленный «Сверчок на печи» - и рисует это положительное начало, воплощенное великим человеком «большого сердца» - Диккенсом.

Вторая новая постановка «Потоп» представляет антитезу первой. Это - сатира на торжество над человеком начал противоположных.

В связи с изложенным, если у нас и происходит напряженная работа над формой, то целью всегда остается выразить посредством формы содержание, общую идею...

\section{8) página 35}

Театр будущего, Театр с большой буквы стал целью Сулержицкого. Новому делу он отдал всего себя без остатка.

\section{9) página 35}

Сулер записал речь Станиславского о принципах будущей студии: «Студия существует при Художественном театре, в помощь ему. Она работает над вопросами актерского творчества (система), педагогически образовывая артиста, доставляя ему практику с помощью ежедневных упражнений и, быть может, в будущем, параллельных спектаклей.... Производит новые опыты совместного творчества авторов, актеров и режиссеров над созданием пьесы (горьковский метод). Опыты над декоративными и световыми эффектами и возможностями сцены. Опыты над пантомимой для больших постановочных спектаклей. Опыты по хозяйственной части. Изыскание способов правильного ведения театрального хозяйства». 
20) página 38

... Пошлость и хамство - вот две самые утомительные для меня вещи. А приходится наталкиваться на них ежедневна и терпеть. Иногда терплю, а иногда так это начинает раздражать, что не могу больше вынести.

\section{1) Página 38}

Мне кажется, в штампах и напряжениях бывает два рода — мышечный и нервный.

Мышечный - это когда человек, ничего не чувствуя, старается по памяти головной заставить мышцы, участвующие в выражении того или другого чувства, сокращаться и таким образом передавать чувства. Некоторые актеры это делают очень ловко, очень похоже, даже при абсолютной внутренней пустоте, - но все-таки мы, то есть наш театр, даже ученики, довольно легко его различаем и угадываем.

Другой же штамп - нервный, когда актер находит чувство живое, через правильный анализ пьесы, зерно, сквозное действие, через задачи и т. д., то есть правильным путем найдя и себя и живые чувства, и потом, постепенно забывая, для чего эти чувства, начинает жить только чувствами, раздражая себе чувствующие нервы, через которые эти чувства проходили, создаваясь. Он даже искренен в своих чувствах, но бесцелен и потому не нужен на сцене.

Первый штамп может быть без всякой работы над ролью, второй же образуется на спектаклях.

Первый, мне кажется, похож на человека, который руками тянет цветок из земли, чтобы он вырос, пальцами расправляет бутоны и т. д., совершенно не думая о корнях. Второй посадил семя, ухаживает за корнями, поливает, окапывает до тех пор, пока цветок не вырос. Когда же вырос, то забрасывает понемногу корни и все внимание обращает на цветок и, чтобы он был красивее, начинает его красить масляными красками; от этого корни сохнут еще больше, и в свою очередь от этого уже бледнеют и цветы; тогда их подкрашивают еще больше, и все растение совсем засыхает, и остается одна мертвая, противная, размалеванная кукла.

А где же тот, который всегда будет ухаживать только за корнями и добьется пышного расцвета всего растения? Таких мало. Это удел больших дарований. Или (отчасти) людей, если и не очень больших дарований, то крупного, значительного миросозерцания, для которых никогда их чувства, сила их, показывание этих чувств толпе, и таким образом превозношение себя перед ней не будет на первом плане и не затмит того, ради чего им приятно и радостно переживать эти чувства на сцене.

\section{2) Página 39}

Несколько излюбленных «тончиков» (у одного - два, у другого - три, шесть) всегда имеются в запасе у каждого актера. И когда актер пуст, когда роль не дается, а говорить и играть как-нибудь надо, тотчас же на помощь появляется «тончик» или комбинации их. Эта условная манера, этот тончик, который у некоторых актеров бывает чрезвычайно приятным, обаятельным и даже благородным, в большинстве случаев в прессе и публике принимается за индивидуальность, так как у всякого актера он другой, хотя внутреннее построение его всегда одинаково.

\section{3) página 40}

Спектакль играется на зрителей. Зал на 120 мест дышит единым дыханием с семьей Шольц. Действию на сцене все чаще сопутствуют истерические вскрики в зале, конечно, женские. Дамы, скромно одетые барышни-курсистки или служащие (их все больше - телефонистки, машинистки, стенографистки, конторщицы, чертежницы) - плачут в зале, плач переходит во вскрики, в удушье. Женщина выходит среди действия, или ее приходится вывести - под руки. Дать понюхать нашатыря. Помочь дойти до дамского туалета, где можно причесаться, припудриться - уехать на извозчике в собственную квартирку с елкой, с дорожкой на полу.

\section{4) página40}

Человека, бьющегося в истерике, всегда жалко, так же, как и человека в припадке падучей,(...) / Истерика заразительна./Истерика в театре, в драматических вещах — такой же дурной показатель для актера, как животное гоготание публики в комических вещах.

\section{5) página 41}

Спектакль принимали хорошо: обвинения одних критиков в истеричности, в «будничной комнатной беседе» и т. п. тонули в восторженных отзывах других рецензентов, утверждавших, что на сцене Студии происходит психологическое чудо - подлинность чувств, открытость переживаний, обнаженность сердец. Зрители напряженно следили за событиями, часто раздавались рыдания. Нам 
это нравилось, а Сулержицкий страдал от такого дикарского понимания успеха, ругался с нами.

- Поймите, - надрывался он, - раз в зале истерика, - значит, играете отвратительно! Нужно трогать фантазию, душу, а вы дергаете нервы. Это чуждо искусству!

Мы верили Леопольду Антоновичу, но, что скрывать, еще больше - всхлипываниям и аплодисментам. И уж конечно, возомнили о себе, когда после спектакля увидели Горького: поднимаясь к нам по скрипучей узкой лестнице, он плакал в огромный носовой платок. За ним, тоже плача, шла Мария Федоровна Андреева. Они захвалили нас, удивлялись, как это при такой молодости мы показываем совершенно «взрослое» искусство. Их восхищение укрепило репутацию спектакля, хотя прав, конечно, был Сулер - потом мы это поняли.

\section{6) página 41}

Истерика заразительна. И вот это сейчас происходит.

И вот почему мне не понравилась эта истерика у нас в студии. Это опасный путь. Такой спектакль может иметь шумный успех, так как это то, что называется «сильно действует», - публика это любит, обожает, как любит бой быков, борьбу, театры ужасов, страшные упражнения с огнем, прыжки, опасные для жизни, - все, что «потрясает» и поэтому развлекает, а не углубляет, но тогда театр перестает быть высшим местом, а становится в ряды всего, что развлекает...

\section{7) página42}

Сулержицкий верно формулировал опасности, которые были заключены в углубленном психологизме, и противоречия, которых он страстно желал избежать. Каждое выступление актера на сцене должно быть новым творчеством;исполнение, которое выветривалось — как он часто наблюдал, - обращалось в опаснейший штамп.

\section{8) página42}

Истерика ужасно заразительна и с каждым годом нашей безумной жизни становится заразительнее и психологически (от мелкоты и суетности желаний обратить на себя внимание) и физически (от невероятных, нездоровых условий жизни, от отсутствия физического труда и всего того, что так безвозвратно растрепывает нам нервы и создает почву для всевозможных нервных заболеваний).

\section{9) página44}

Занятия «системой» и соответственно вся миссия Студии для Станиславского в значительной мере определялись тем, что он, как сказано в его известном письме к Мейерхольду, «совершенно изверился во всем, что служит глазу и слуху на сцене. Верю только чувству, переживанию и, главное, самой природе».

\section{0) página44-5}

Упражнения должны быть отдельно: на ослабление мышц, на введение себя в круг,

на утверждение себя в вере, наивности,

на умение привести себя в какое бы то ни было аффективное состояние, на умение привести себя к ощущению того, что К. С. называет «я есмь», при разных имеющихся налицо тех или иных комплексах случайностей и т. д., на установление живого объекта, на возбуждение в себе всеми этими путями работоспособного состояния и т. д.

Кроме того, все эти задачи должны быть увлекательны, должны заинтересовать волю, так как, повыражению К. С., всегда им высказываемому, «воле творческой приказывать ничего нельзя, - можно только увлекать ее».

При перестройке образов в «Горе от ума» - его указания М. Н. Г. ${ }^{58}$ : «Не начинайте отказываться от тех или иных черт вашего образа, не изгоняйте их насильно, они сами уйдут, если вы заинтересуете себя другимикрасками, которые и станут на место ненужных вам сами собой, потому что вы больше их полюбите».

\section{1) página45}

А я бы еще прибавил, что, пожалуй, надо, чтобы эти задачи были увлекательны также не только для актера, но и для наблюдающего за этими упражнениями, режиссера или преподавателя.

\section{2) página46}

Но чем больше молодежь, сплотившуюся в Первой студии, воодушевляли занятия «системой», тем сильнее ученикам Станиславского хотелось играть, испытать на публике усвоенные методы. В конечном счете всякая театральная Студия таит в себе потенцию возникновения театра. 


\section{3) página 46}

Если бы меня спросили, каковы основные черты студийца, которые можно выразить в 2-х - трех словах, я бы сказал:

Если вы мне скажете, что это трудно достижимо в скором времени, я бы сказал, что ставится как идеал, как направление, в котором мы должны работать, и чем мы дальше от него, тем энергичнее мы должны в этом направлении работать и не падать духом, видя свое несовершенство. Практичность в дух. и в мат., поменьше правил и законов. Уважение к человеку и художнику, внимание, доверие, и снисходительность - к другим, строгость и требовательность к себе - вот главные черты Студийца.

\section{4) página 49}

Сулержицкий хотел проникнуть к истокам творчества, хотел найти зерно наивного творчества, потому что сам он был глубоко наивен.

\section{5) página50}

Режиссер студии считается всякий тот, кто довел свою пьесу до генеральной репетиции хотя бы эта пьеса и не дошла до публики (...) Каждый режиссер имеет право брать какую угодно пьесу, и распределять в ней как угодно роли. Собранию должно быть известно кто и какую пьесу выбрал, и каких исполнителей назначил, но без права изменения или запрещения (- ни ролей) Осведомление Р.С. необходимо для 2-х целей а) обсудить в собрании вместе с товарищами и отстоять перед ними с художественной стороны правоту своего распределения, это необходимо всем в смысле приобретения опыта в умении распределять роли. Но голос представляющего свою пьесу, если он даже и не изменит после совещания ни одного исполнителя, остается в силе и изменен быть никем не может, кроме К.C - a

б) Осведомление это необходимо для организационных целей; Р. Собрание должно проверить: может ли данный исполнитель совместить данную роль с уже заранее им взятыми. Р.С. должно дать данной постановке время и место среди студийных работ как для репетиций, так и для спектакля, когда он будет готов. Когда роли распределены и время и место найдено председатель Р.С. докладывает об этом до сведения К.С. Когда роли К.С. подписаны пьеса поступает в работу.

\section{6) página51}

В России повести, рассказы диалогичны, автор-повествователь часто предоставляет слово персонажу...

\section{7) página51-2}

Tackleton the Toy-merchant, pretty generally known as Gruff and Tackleton -- for that was the firm, though Gruff had been bought out long ago; only leaving his name, and as some said his nature, according to its Dictionary meaning, in the business -- Tackleton the Toy-merchant, was a man whose vocation had been quite misunderstood by his Parents and Guardians. If they had made him a Money Lender, or a sharp Attorney, or a Sheriff's Officer, or a Broker, he might have sown his discontented oats in his youth, and, after having had the full run of himself in ill-natured transactions, might have turned out amiable, at last, for the sake of a little freshness and novelty. But, cramped and chafing in the peace- able pursuit of toymaking, he was a domestic Ogre, who had been living on children all his life, and was their implacable enemy. He despised all toys; wouldn't have bought one for the world; delighted, in his malice, to insinuate grim expressions into the faces of brown-paper farmers who drove pigs to market, bellmen who advertised lost lawyers' con- sciences, moveable old ladies who darned stockings or carved pies; and other like samples of his stock-in- trade. In appalling masks; hideous, hair, red-eyed Jacks in Boxes; Vampire Kites; demoniacal Tum- blers who wouldn't lie down, and were perpetually flying forward, to stare infants out of countenance; his soul perfectly revelled. They were his only relief, and safety-valve. He was great in such inventions. Anything suggestive of a Ponynightmare, was delicious to him.

\section{8) página52}

'Mrs. Peerybingle!' said the Toy-merchant, hat in hand. 'I'm sorry. I'm more sorry than I was this morning. I have had time to think of it. John Peery- bingle! I'm sour by disposition; but I can't help being sweetened, more or less, by coming face to face with such a man as you. Caleb! This uncon- scious little nurse gave me a broken hint last night of which I have found the thread. I blush to think how easily I might have bound you and your daugh- ter to me, and what a miserable idiot I was, when I took her for one! Friends, one and all, my house is very lonely to-night. I have not so much as a Cricket on my Hearth. I have scared them all away. Be gracious to me; let me join this happy party! 


\section{9) página 52-53}

Мы хорошо знаем улыбку твою, нам не нужно ее видеть, чтобы почувствовать.

Вот ты на беседе о «Сверчке».

Суетливо бегает твой карандаш по клочку бумаги, ставит непроизвольно знаки, зачеркивает их.

Вот ты положил карандаш, хлопнул им по сукну стола.

Это значит - ты остановился на чем-то. Сосредоточенно углубляешься в себя, снова берешь карандаш, делаешь им какой-то зовущий жест и говоришь нам: «Я не знаю, может быть, к “Сверчку” нужен особый подход, может быть, нужно начать репетиции не так, как всегда делали, может быть, лучше сейчас пойти в Страстной монастырь, постоять там молча, прийти сюда, затопить камин, сесть вокруг него всем вместе и при свече читать Евангелие».

Ты говорил нам:

«Доберитесь до сердца Диккенса, откройте его - тогда откроется вам сердце зрителя. Только ради этой цели стоит и нужно ставить “Сверчка”. Людям трудно живется, надо принести им чистую радость.

Когда вы берете пьесу для постановки, - спросите себя, ради чего вы ее ставите». Разве этот завет твой можно забыть, пока существует студия?

\section{0) página 54}

Началось чудо с первого же момента, когда в черной темноте заструились какие-то наивно-простые музыкальные звуки, прокраснел в этой темноте огонек в углу направо, и вырвал из нее чей-то смутный, точно дрожащий, не желающий оформиться прочно, облик. Мягким хриплым шепотком кто-то из темноты стал рассказывать о сердито-подбоченившемся и обиженно закипевшем чайнике, о сверчке на печи и его милой песне, об извозчике Джоне Пирибингле, который вот сейчас везет во вьюгу почту и который так любит свою жену — «малютку», и о самой «малютке». Мягко струился шепот. И с этими шепотами, с этими звуками, шумами, напоминаниями, обещаниями стало литься в душу, сквозь броню, что выковали вокруг нее настроения и тревоги военных дней, — великое очарование. Оттаивал какой-то лед у сердца (...)

\section{1) página 56}

К толстовскому учению спектакль не сводился, но оно прорастало в спектакль как прорастает из одного зерна колос, несущий множество зерен. Со временем определение стало отрицанием. «Толстовство» с конца 20х годов до девяностых - словно пункт в анкете, который предпочли бы не заполнять: - Ни в каких партиях не состоял, но был последователем учения Л. Толстого... Анкетная графа с упоминанием имени графа Толстого не менее опасна, нежели признание — «был эсером», в эпоху, когда лозунгом общества стало высказывание Горького: «Если враг не сдается...» В театре слово «толстовство» - укор, недостаток, который следует преодолевать. Как Вахтангов преодолел влияние Сулержицкого. Об этом писали очень одаренные ученики Станиславского Сулера - Вахтангова. Со временем этикетка так приклеилась к спектаклю, что отсутствие ее в студенческом ли ответе на экзамене, в музейной экспозиции, в автореферате диссертации обязательно замечалось.

\section{2) página57}

Бедность обстановки резко контрастировала с тогдашним оформлением спектаклей МХТ; Первая студия не имела дела с именитыми живописцами, ее художники (И. Я. Гремиславский, М. В. Либаков, П. Г. Узунов) историкам изобразительного искусства неведомы. С помощью этих скромных художников создавалась эскизная система немногочисленных опознавательных знаков, достаточных, чтобы возникло «ощущение комнаты», или «ощущение бара», или «ощущение мастерской».

\section{3) página57}

«четвертая стена», обязательная для спектаклей раннего МХТ,тут не обладала священной неприкосновенностью и непроницаемостью. Как уже сказано, актер мог вплотную подойти к зрителям первого ряда. Условная линия четвертой стены в этот миг разрывалась. Возникала возможность непосредственного общения со зрительным залом: не вызывающе смелой игры на краю просцениума, не специального подчеркивания условности, которое так любил Мейерхольд и которое несло с собой чрезвычайную остроту ощущения Театра, но, напротив, самого скромного и самого искреннего излияния своих сокровеннейших переживаний на публике, публично.”

\section{4) Página59}


- Странный Константин...

И после длинной паузы добавил:

- Пишет, чтобы я не работал много... А как я могу не работать много, когда мне так мало осталось жить.

\section{5) página60}

И везде, даже в маленьких строчках, ты взываешь к милосердию, к любви, к чуткости, к добрым отношениям. Каждое твое предложение или замечание имело мотивом сердце.

\section{6) Página 59}

Если все стены, вся студия будет пропитана своим трудом, приложенным для ее улучшения, вы увидите, как тут вырастет студия, как она будет ценима и уважаема и как каждому будет оскорбительно чьелибо легкомысленное и невнимательное поведение.

\section{7) página63}

Почему он так полюбил студию? Потому что она осуществляла одну из главных его жизненных целей: сближать людей между собой, создавать общее дело, общие цели, общий труд и радость, бороться с пошлостью, насилием и несправедливостью, служить любви и природе, красоте и богу.

\section{8) página63}

В каждом занятии по системе он говорил не только о самодовлеющем искусстве актера, но актера он видел в живом человеке. И этот «живой человек» был главной целью его забот. Не расхлябанный обыватель, не фантастически настроенный художник, а смелый, прекрасный, с трезвой, ясной мыслью и обаятельной простотой, словом, гармонически развитый человек - вот каким должен быть актер. И мало того, этот актер должен говорить только о прекрасном. Всегда звать людей к прекрасным делам, не давать им возможности окунуться в тину мещанства и обывательщины. Искусство актера - великое средство воспитания и поднятия людей.

\section{9) página63-4}

La belleza conduce al hombre, que solo por los sentidos vive, al ejercicio de la forma y del pensamento; la belleza devuelve al hombre, sumido en la tarea espiritual, al trato con la matéria y el mundo sensible.

\section{0) página64}

Arte bello, en cambio, es un modo de representación que por si mismo es conforme a fin, y aunque sin fin, fomenta, sin embargo, la cultura de las faculdades del espíritu para la comunicación social.

La universal comunicabilidad de un placer lleva ya consigo en su concepto, la condición de que no debe ser un placer del goce nacido de la mera sensación, sino de la reflexión, y asi el arte estético, como arte bello, es de tal índole, que tiene por medida el juicio reflexionante y no la sensación de los sentidos.

\section{1) página64-5}

Дорогой Константин Сергеевич, что тут делается, если бы Вы только знали! Какая все это сволочь. Измучили меня, истрепали так, как не помню, когда я чувствовал себя так. Ничего не сделано. Вещи, которые я заказал им еще в декабре, заказываются только сегодня (как костюмы звезд), - 26-го спектакль, а звезд еще не репетировали, костюмов еще никаких я не видал, декорации Ночи переделали (написали задник), и потому призраки не выходят, - электрический ток слабый, дисциплины никакой, никто ничего не слушает, заказы не выполняются, все лгут, обманывают, и все из-за экономии. Меняют актеров без конца. Нарочно нанимают дешевых актеров для репетиций, чтобы дешевле платить, а за три дня меняют, нанимают «гранд артистов», которые такая же дрянь, как и дешевые, только громче кричат, топают и машут руками.

А мне приходится репетировать со всеми ними. Переменили двух Котов, теперь, с позавчерашнего дня, - новый; завтра придет вторая Фея, так как этой отказали, третий Насморк и т. д. без конца. Мерзавцы и негодяи! Если бы не ответственность за наш театр, давно бы плюнул и убежал отсюда. Пошлости вносят без 477 конца. И все это делается именем Метерлинка. «Метерлинк сказал», «Метерлинк так хочет» — и я умолкаю. Что же можно сказать против автора?

А он сидит тут же и говорит, что надо, чтобы все было живее, чтобы скорее говорили, что хоровод в первом акте надо сделать веселее, что французская публика любит, чтобы было светло и весело, и т. д., ввел балет часов - дам, выходящих из нортоновских часов, неизвестно как оказавшихся в доме у бедного дровосека.

Орут, галдят, сделали какой-то зверинец и цирк - и все, что так нравилось актерам в нашей 
постановке, все, чем удалось мне их увлечь и создать хоть какое-нибудь благородство на сцене, все это теперь затоптано цирковыми клоунскими выходками, лаем, мяуканьем, вытьем, грубой дракой...

Смотреть невыносимо.

Прибавили еще громадную картину, которую Вы читали: «Бонёр»313, и вчера делали первую репетицию под руководством Леблан, которая сказала, что ей довольно полутора часов в день, в течение пяти оставшихся дней, чтобы поставить этот труднейший акт, на который у нас надо не меньше двух месяцев.

Прибавили «Кладбище», которое я один раз в два часа ночи прошел с дремлющими актерами314.

Безжалостность к детям, которых держат до двух часов ночи, без нужды, потому что в это время Леблан беседует с Режан о костюмах.

Вот ад и подлость!

Не верю я, чтобы публике Парижа понравилась эта грубая безвкусная вещь, которую из нее делают парижские актеры под руководством автора и Режан. Я видел здесь бельгийскую труппу, которая 350 раз уже сыграла небольшую комедийку, и вижу, что французы отлично понимают тонкий вкус и благородство игры, тонкий юмор без жеста, без ломанья и паясничанья, и все то безвкусие, которое вносят в пьесу Леблан и Режан и которое они навязывают парижской театральной публике, есть их личное безвкусие, и только.

Не знаю, как быть с афишей? Писать ли, что постановка скопирована с Московского Художественного театра, или выгоднее не писать?

Конечно, мы под такой постановкой не подписались бы ни за что, - но вместе с тем успех может быть, и даже, как все говорят, он будет непременно. Как быть? Идти на риск или нет?

Ответьте мне телеграммой.

Что касается Метерлинка, то пьесу он уже обещал нам, и на днях я буду иметь ее в руках, а через шесть месяцев после того, как ее поставят у нас, они хотят поставить ее в Париже, но уже без Режан, в своем театре, так как они считают, что Режан виной всему этому беспорядку и мерзости.

Так что если главное дело - хорошее отношение Метерлинка к нам, то оно сделано.

А относительно рекламы театра, - не знаю, как быть? Что выгоднее? Все-таки, пожалуй, пусть напечатают. Ведь не дураки же здесь, и авось догадаются, что если плохо, то не потому, что в МХT плохо, а потому, что не сумели взять. А все-таки лишний раз узнают, что есть такой театр на свете. Нам необходимо сюда приехать. Французы рот разинут, и успех будет колоссальный, умопотрясающий. Почему Немирович не ответил на серьезное предложение одного предпринимателя, который давал какие угодно деньги? То есть ни звука не ответил. Стыдно было принимать справедливые упреки в невежливости и, собственно говоря, глупости.

Крэга еще не отчитывал. Он в ужасно бедственном положении. Занял у меня вчера 20 франков, так как нет ни гроша. Куда он девал все эти деньги? Если бы я получил столько, я уже жил бы у себя на даче и работал бы в театре, как меценат. Однако денег у него нет, и он просил меня телеграфировать Вам, чтобы ему хоть что-нибудь выслали из театра. Он говорит, что ему сказали, что его выпишут два раза в год за такую-то сумму, и он согласился, предполагая, что оба раза он должен быть вызван в течение одного года. Между тем второй его приезд назначен уже за пределами того года, в котором делалось условие, и поэтому он считает, что ему надо платить снова за его приезд в новом году, так как условие уже исчерпано одним годом. Он говорит, что нельзя первый раз выписать его в 1909 году, а второй раз в 1910, что условие простирается только на один год. И если его не вызвали в течение этого года второй раз, то надо снова платить. Поэтому он просит аванса. Очевидно, он хочет теперь переделать свое условие в годовое. Путает, но нуждается в деньгах ужасно. А может быть, он копит и откладывает? Совершенно непонятно, куда он девает деньги при такой жизни. Знаю, что взял у меня 20 франков и просил телеграфировать Вам, так как у него не осталось ни гроша.

Целую Вас крепко и очень скучаю, и очень страдаю здесь от этой лжи, обмана, непорядочности, безвкусия и пошлости, в которой мне приходится находиться.

Физически страшно утомлен - болит голова, сердце, тошнит каждый день, очевидно, почки в полном разгаре. Боюсь делать анализ. Впечатление у меня такое, как будто меня бросили на съедение диким зверям.

Кроме того, каждый день Режан торгуется со мной и хочет, чтобы я нес эту адскую работу за 50 франков в день.

Целую Вас крепко и горячо, верно любящий Вас -

Ваш Сулер.

Хочется плакать от обид и за себя, и за Вас, и за то, что Вы сделали в «Синей птице».

Ужасно, мучительно одиночество при таких условиях. И как не хочется заболеть из-за этой мерзости! А, кажется, придется. 
Еще раз горячо целую Вас, милый, хороший Константин Сергеевич. Ваш Сулер.

\section{2) página66-7}

El artista, al igual que el resto de los ciudadanos está obligado a conocer las leyes de la ética social y subordinarse a las mismas.

La ética artística es la ética profesional de la gente de teatro. Sus bases son las mismas que las de la ética social pero ellas deberán adaptarse a las condiciones de nuestro arte. Estas condiciones son diversas y complejas.

La primera de ellas estriba en lo colectivo del trabajo del poeta, del regisseur, del artista, de los escenógrafos, de los músicos, de los bailarines, de los maquiladores, de los encargados de vestuario, de todo el resto del personal teatral.

Cada uno de ellos por separado es un creador independiente en su campo de acción dentro de nuestro arte. Tomados conjuntamente están ligados entre si por las leyes de la armonía artística y por el objetivo común y final para todos que es la creación. Para regular entre si el trabajo de muchos creadores y cuidar la libertad de cada uno de ellos en particular, son necesarios principios morales promotores del respecto a la creación ajena que mantengan el espíritu de camaradería en el trabajo común, que cuiden la libertad de creación propia y ajena y que morigeren el egoísmo y los instintos nocivos de cada uno de los trabajadores del colectivo tomados individualmente.

La ética artística crea estos principios morales adaptándo-se a las condiciones de nuestro arte.

\section{3) página68}

Todo compromiso es por si mesmo, enganoso ya que consiente las pasiones invariables dominantes en el individuo.

En la atmosfera de la lisonja, la vanidad y la admiración que rodean el artista el poder de la tentación se agudiza. Por otra parte el bienestar material del artista se encuentra en relación directa con el éxito y este último en dependencia de los caprichos del público, amigo de crearse ídolos y de destronarlos.

He aquí porque la vanidad y el cálculo material tan a menudo obligan a los artistas a abandonar sus ideales estéticos.

\section{4) Páginas 68-9}

И студии он оставил завет: репертуар театра должен быть построен так, чтобы в каждой пьесе отражалась природа высокого духа человека, всегда напоминающая, всегда зовущая его к лучшей жизни. И в этом движении к лучшему и есть путь совершенствования личности художника.

Творчество - акт этого совершенствования.

Так сторона «этическая»— как выражался Леопольд Антонович - тесно связана с «эстетической» стороной.

«Без этики нет эстетики» - постоянный лейтмотив его бесед и практической деятельности. В искусстве важно не только что (то есть содержание, в самом широком смысле этого слова), но и как(то есть форма). Форма без содержания - пустоцвет. Содержание без формы не произведение искусства. И то и другое неотделимы, одно без другого не могут существовать в произведении истинного искусства.

\section{5) Р69 -72}

Господа студийцы,

обращаю ваше серьезнейшее внимание на вещи, которые позорят вашу студию или, если это слишком

сильно, то по крайней мере не дают ей возможности стать такой, за какую вы ее хотели бы считать.

Это ваше отношение к прислуге.

Нельзя пользоваться трудом людей, не обращая внимания на то, как эти люди живут, в каких условиях, как спят, как одеты, как отдыхают, есть ли у них место и время пообедать, не в грязи ли они и т. д. Труд очень напряженный; вы берете у них и день и ночь, а даете только жалованье, а дальше совершенно наплевать.

Я понимаю, что спрашивать человеческого внимания к ним, к каждому отдельному человеку как кчеловеку трудно, так как мы и к более близким людям недостаточно внимательны, но быть 373 тем, что в Англии называется «выжимателями пота», все-таки довольно позорно.

Ведь мы пользуемся рабовладельческими приемами. Таких негигиенических, отвратительных условий, такого невнимания к рабочему человеку я давно уже не видал. И это в таком деле, где 
молодые люди собрались заниматься искусством, цель которого заставить людей быть внимательнылми друг к другу, цель которого смягчать сердца, облагораживать нравы. Эта сторона большой пропуск в вашей жизни, опасный не для работы, а для вас.

Разрешить его путем прибавки двух-трех рублей жалованья никак нельзя, - это значит только, что из людей, пользующихся рабами, вы будете такими, которые пользуются ими не ниже той цены, которая установлена на рынке, и только, а человеческое начинается только с того момента, когда хоть маленькое, минимальное внимание затрачивается лично на личную жизнь каждого. Хоть минимальное.

Для этого необходимо хоть раз ясно представить себе, как проходит жизнь каждого из них.

Вот, например, должность истопника. С утра он должен наколоть дров на все печи, которых у нас в квартире двенадцать, на каждую надо полен пятнадцать - это около двухсот полен_; надо их все принести, а расстояние от сарая нашего такое, как если обойти весь квартал, поднять их на третий этаж, разнести по печам, потом мешать эти печи, потом все закрыть, выгребать золу, ставить самовары, бегать на посылки, стоять в передней, потом, пообедав стоя, потому что сесть негде, продолжать ту же службу, ходя целый день на цыпочках, из почтения, что очень утомительно, а вечером, до двенадцати, готовить, и разносить чай, и убирать. Затем без ужина надо ложиться в душной каморке, где поставлена еще кровать, на которой два брата, проведшие в таком же роде, если не хуже, день, лежат вдвоем на одной кровати.

Нехорошо. Помните, что у этих людей нет дома, что эта душная, грязная каморка и есть дом, что ни уюта, ни внимания, ни домашней заботы, ни внимательного слова, а так в этом неодухотворенном, суматошном, рабском - потому что для них лично непонятном - труде проходит сначала отрочество, потом юность, потом взрослая жизнь и потом старость. В пыли, духоте, подневольности и, главное, без малейшего намека на что-нибудь, что хоть как-нибудь коснулось бы духовной стороны человека. Разве подглядят чтонибудь в щелку, как господа поют и играют, как вчера на пробном концерте.

И это в том учреждении, которое только и наполнено рафинированным искусством.

Сами следите, чтобы все это было почеловечнее. Не поддавайтесь ложному стыду и хоть немножко поузнайте, как живут те люди, которые несут за вас черный труд, а если попытаетесь 374 когда-нибудь внести какую-нибудь капельку удовольствия в их жизнь, то поверьте, что эта капелька не пропадет.

Физический труд вовсе не такая вещь, которой надо избегать, она может дать большую радость, но услужение, служба, постоянная зависимость от других и абсолютное отсутствие какого бы то ни было тепла и внимания создают такую безотрадность, так гнетут и унижают человека, что он вконец теряет интерес даже к себе, и черствеет, и глохнет, и создается раб вместо человека, потерявшего себя; участвовать вам в этом не годится; слишком вы богаты духовными радостями и богатствами по сравнению с ними. Пусть и им хоть немножко померещится иногда, что у них есть «дом». Пусть хоть изредка, ложась после трудного дня, он почувствует, что кто-то хоть немножко подумал о нем, и заснет без сознания, что он куплен, его труд, и затем что дальше всем все равно. Чтобы эти стены, если и не очень удобные, были бы ему все-таки теплы и приятны, чтобы за ними было хоть немножко теплее, чем там, на улице, где все борьба, где нужны только его руки и ноги, где хотят как можно больше от него взять и как можно меньше дать.

Я не сентиментален. И так немного нужно: только не поступать, как худшие из рабовладельцев. И следите за этим сами, каждый обращаясь к себе в этой области; к себе, потому что пользуется ими именно каждый; и потому что никто не может сделать это за другого.

Если выбираете кого-нибудь, кто будет ими заведовать, то поговорите с ним потихоньку, спросите, разузнайте то, что вас будет интересовать, но, главное, помните, что помочь в этом может только лично каждый. Хотелось бы, чтобы каждый служащий мог сказать «наша студия» и с любовью и с теплым чувством. Да и вообще надо подумать о том, чтобы в студии было теплее и удобнее каждому ее члену. Надо больше сплотиться. Надо больше давать места работе других. Например, сегодня - Тезавровский_е в один день по собственному желанию сколотил необходимые щиты в зрительный зал на окна. Нужно было напряженно проработать плотницкой работой целый день. Разве это не радостно? Если все стены, вся студия будет пропитана своим трудом, приложенным для ее улучшения, вы увидите, как тут вырастет вся студия, как она будет ценима и уважаема каждым и как каждому будет оскорбительно чье-либо легкомысленное и невнимательное поведение. В организме студии не хватает, например, столовой. Сделать ее очень трудно, совершенно верно, - но совершенно необходимо. Соберемся где-то и на ходу обсудим внимательно. Если не хватит денег для начала, я дам, у меня уже есть для этого, хотя мне хотелось бы обойтись. Но это нужно. Только не махайте рукой, не говорите, что это невозможно. В том-то и сила наша, что невозможное, казалось бы, у нас становится возможным и 375 выполнимым. Если самое невозможное, то есть сама студия с ее организацией, ее спектаклями, труппой, бюджетом, ее 
взаимоотношениями оказалась не только возможным, но и существующим и процветающим - ну, разве это не чудо?

Как же можно не верить в такие уже сравнительно с этим пустяки? Людей не найдется? А почему? Почему такое сомнение? Оглянитесь назад - три года назад, и увидев то, что вы же проделали за это время, устыдитесь своего маловерия, вычеркните его поскорее, скорее осмотритесь, поглядите друг другу в лицо, почувствуйте, что вас уже нешуточная группа и не слюнями уже склеенная, а чем-то покрепче, поскорее почувствуйте свою силу, а для этого чаще ощущайте друг друга, скорее бейте заклепки на скрепах нового корабля «Студия» и двигайтесь, дружно подняв флаг: «Вера, Надежда, Любовь», внимательно глядя вперед, потому что за этот год вы должны сделать так много, как, может быть, не сделали за все эти три года.

Каждый должен помнить, что сделаться студийцем можно только оттого, что скажет себе сам: «Я - студиец!» и будет с этого момента полагать, что от него именно зависит все существование студии, от его внимательности и забот о каждой стороне жизни студии, от его уступчивости, от его готовности работать и жертвовать своим трудом, временем, опытом и многим, многим, многим. Приобретаешь тем больше, чем больше жертвуешь.

Это не из хрестоматии, а из жизни - посмотрите на историю всех членов студии и вы увидите, что это так.

Помните только, что вам надо поскорее почувствовать себя сильными единением между собой и сильными единением с тем, что вас создало - Художественным театром. И поскорее — так чует мое сердце.

\section{6) página77}

Я видел, какою необычайною радостью осветилось лицо Льва Николаевича, когда он увидел Сулержицкого переступающим порог его дома в Ясной Поляне. В комнаты тихого особняка вместе с Сулером ворвались песни степей, и на целый день воцарилась в доме та жизнерадостность, которую всегда так трепетно искал Толстой. И тогда же мне казалось, что в Сулержицком Толстой любил не только носителя своих идей, но главным образом его дух бродяжничества.

\section{7) página77}

Сулержицкий любил море, любил, как и Толстой, цыганскую песню, любил музыку — мог ли он пройти мимо театра? Рожденный бродягой, он дал театру то, чего никогда не дает ему артист с обывательской душой.

\section{8) página77}

(...) студия при Художественном театре, руководимая вечно молодым Станиславским, должна облечься в глубокий траур, потеряв такого энергичного бунтаря, как Сулержицкий, - скованный смертью в ночь с 17-го на 18-е декабря 1916 года.

\section{9) Página 79}

В области искусства, творчества ни заставлять, ни приказывать чувствовать так или иначе нельзя. Никакой, даже самый маленький, актер не изменит в созданном им со всеми муками творчества образе ни единой черты, хотя бы это ему приказывал сам Станиславский.

\section{0) página80}

Раз нет личности - нет ничего, и нечего приводить в гармонию, все становится плоским и безразличным.

\section{1) página80}

Вся напряженная работа современного режиссера по отношению к актеру заключается именно в том, чтобы помочь ему найти самого себя, помочь ему, как говорят, «выявить» свою личность до возможно большей глубины, помочь ему отделить в своей работе то, что действительно представляет из себя его настоящую индивидуальность, от общего, театрального, от так называемого «тончика», который, хотя у каждого актера свой и непохож на других, ничего общего с настоящей его индивидуальностью не имеет.

\section{2) página80}

Вот тут талантливый и умный Всеволод Эмильевич Мейерхольд сделал ошибку. К условному театру, к отрицанию реальных подробностей он пошел, забыв актера. Вооруженный прекрасными 
знаниями в области театрального представления, глубоко проникающий в идеи автора, отлично оперирующий ими, поскольку они отвлеченны, Всеволод Эмильевич беспомощно тонет в глубоких переживаниях живых людей, теряясь между стилем и содержанием. В своем стремлении к созданию новых форм театра он перескочил через актера и поплатился за это жестоко.

\section{3) página 81}

Какая концентрированность, какая глубина переживания, какое бесконечное количество темперамента нужны, чтобы своей игрой, помимо главных чувств, заставить публику видеть лес, море, услышать его шум. И какая безумная сосредоточенность и искренность нужны для этого!

\section{4) página83}

И переходить к более примитивной постановке на сукнах и на плоскости возможно только через актера, через великого актера, через школу искреннего переживания и проникновения, через развитие индивидуальности. Переходить надо осторожно, заботливо следя, чтобы степень условности постановки не шла впереди развития актера и тем самым не заставила бы его форсировать свое творчество, что непременно тотчас же отразится самым плачевным образом на его искренности.

\section{5) página 82-3}

У Сулержицкого был портрет Толстого с надписью: «Льву Сулержицкому от Льва Толстого».

Толстой звал Сулержицкого «Левушка».

Лев и Левушка.

В моей памяти они неразлучны.

\section{6) página84}

у него никогда не было «жертвенности», сознания исключительности своего положения, тягостного ощущения разрыва между собой и крестьянами, которое почти всегда было свойственно тогдашним интеллигентам — от народников до толстовцев.

\section{7) página84}

(...) здоровое человеческое начало, «крестьянская жилка», всегда близкая Толстому, та радость жизни, душевная ясность, которой полон был Сулержицкий и которая очень сильна была в Толстом.

\section{8) página84-5}

Он подходил к людям с драгоценным даром — радостью и смехом.

\section{9) página85}

Жизнь должна быть прекрасна.

Люди должны быть счастливы.

И для осуществления этих двух целей не следует пренебрегать никаким, даже самым мелким и пустым, поступком.

Если можно дать людям веселье забавным рассказом или смешным анекдотом - то да здравствует веселый рассказ и смешной анекдот!

Если можно украсить жизнь людей картиной, представлением, песней, и для этого нужен труд, - то надо дать его с охотой и весельем.

Если для счастья людей понадобится страдание - надо идти на него бодро, уверенно и радостно.

Вот в коротких словах «profession de foi» недавно ушедшего из этой жизни моего товарища по Школе живописи и ваяния - Л. А. Сулержицкого.

Не знаю, как сам он определил бы свое внутреннее миросозерцание. Может быть, и иначе, чем я это делаю. Может быть, в нем бессознательно жила та страстная любовь к жизни и ко всему прекрасному в ней, которая заставляла его весело работать и радостно страдать. Но всякий, знавший Сулержицкого, не только чувствовал это его свойство, но и заражался им.

\section{0) página85}


Он зачитывался религиозно-философскими сочинениями отца, слушал его беседы с многочисленными посетителями и скоро стал очень близким ему человеком по взглядам и убеждениям.

71) página86-7

Сулер - ненадежен. Никогда не знаешь, что он сделает завтра - бросит бомбу или уйдет в хор песенников

\section{2) página87}

- А все-таки вы не уверены в том, что защищаете, - вдруг сказал Сулер, улыбаясь. Лев Николаевич взглянул на него острым взглядом и, засмеявшись, погрозил пальцем, но не сказал ни слова

\section{3) página87}

(...) Сулер, подпавши под влияние Толстого, не потерял своей самобытности. Несмотря на глубокую мысль, постоянно работавшую в голове Сулера, он остался веселым забавником и тонким художником, каким был и прежде.

\section{4) página87}

Сулержицкого называли толстовцем, но если это и было так, то он был толстовец особенного типа. Ни следа фанатизма или сектантства не было в нем.

\section{5) página89}

- Ну, какой он толстовец? Он просто — «Три мушкетера», не один из трех, а все трое!

Это сказано совершенно верно и как нельзя более точно очерчивает яркую индивидуальность

\section{6) página89}

Сулера, с его любовью к делу, к работе, с наклонностью к донкихотским приключениям и романтической страстью ко всему, что красиво.

\section{7) Página 88}

Так, значит, не толстовец? - Конечно! - и в то же время было бы глубоко неверно отрицать громадное влияние Льва Толстого на Сулера, на всю его жизнь и мировоззрение. Сулержицкий всегда любил Толстого - человека и художника. А о влюбленности Толстого в Сулержицкого вспоминают все бывавшие в Ясной Поляне в 90-900-е годы; об этом свидетельствуют

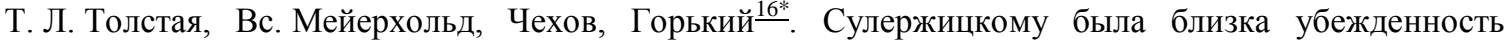
Толстого в необходимости личного усовершенствования, уверенность в том, что каждый человек должен делать все, чтобы самому стать лучше, принести людям помощь и добро. Как Толстой, он отрицал строй современного государства, основанный на насилии и несправедливости. Как Толстой, ненавидел буржуазию, ее самодовольную ограниченность, как Толстой, отрицал церковь, ее обрядность и стремился следовать «чистому» учению Христа, евангельским заветам братской любви к ближнему.

\section{8) Página88-9}

Сулержицкий сидел в тюрьме за отказ от воинской повинности. Его посетил Толстой. Стояли они молча друг перед другом, разделенные решеткой.

Толстой покойно смотрел из себя на Сулержицкого. Сулержицкий, чуть наклонив голову, взглядывая на Толстого, покорно ждал.

- Пьете?

- Нет.

Молчание.

- Курите?

- Нет.

Молчание.

- А женщины?

- Нет. 
Толстой ласково прищурился. Помолчал.

Простились тоже молча.

Вот и весь разговор.

Разве не страшно?

Не убий, не укради, не прелюбы сотвори.

\section{9) Página89}

[Но как только я его увидела - так мое настроение тотчас же изменилось.] Он был такой же веселый и жизнерадостный, как всегда, и мы через две минуты болтали с ним так же свободно, как будто мы находились в нашей старой любимой Школе или в хамовническом доме.

\section{0) (página89-90) Дорогой Леопольд Антонович.}

Всей душой страдал с вами, читая ваше последнее письмо. Не мучайтесь, дорогой друг. Дело не в том, что вы сделали, а в том, что у вас в душе; важна та работа, которая совершается в душе, приближая вас к богу; а я уверен, что все то, что вы пережили, не удалило вас, а приблизило к нему. Поступок и то положение, в которое становится человек вследствие совершенного поступка, не имеет само по себе никакого значения. Всякий поступок и положение, в которое становится вследствие его человек, имеет значение только по той борьбе, которая происходила в душе, по силе искушения, с которой шла борьба, а у вас борьба была страшно трудная, и в борьбе этой вы избрали то, что должно было избрать. Не нарочно, а искренно говорю, что на вашем месте я наверное поступил бы так же, как вы, потому что мне кажется, что так и должно было поступить. Ведь все, что вы делали, отказываясь от военной службы, вы делали для того, чтобы не нарушить закона любви, а какое нарушение любви больше, - стать в ряды солдат или остаться холодным к страданиям старика?

Бывают такие страшные дилеммы, и только совесть наша и бог знают, что для себя, своей личности мы сделали и делаем то, что делаем, - или для бога. Такие положения, если они избраны наверное для бога, бывают даже выгодны: мы падаем во мнении людей (не близких людей, христиан, а толпы) и от этого тверже опираемся на бога ${ }^{79}$.

Не печальтесь, милый друг, а радуйтесь тому испытанию, которое вам послал бог. Он посылает испытание по силам. И потому старайтесь оправдать его надежду на вас. Не отчаивайтесь, не сворачивайте с того пути, по которому идете, потому что это единственно узкий путь; все больше и больше проникайтесь желанием познать его волю и исполняйте ее, не обращая внимания на свое положение, а главное, на то, что думают люди. Будьте только смиренны, правдивы и любовны, и как бы ни казалось запутанным то положение, в котором вы находитесь, оно само распутается. Самое трудное то состояние, когда весы колеблются и не знаешь, которая чаша перетягивает, - уже пережито вами. Продолжайте так же любовно жить, как вы жили с окружающими - смиренно, правдиво — и все будет хорошо.

Лев Толстой. Несравненно больше люблю вас теперь, после перенесенного вами страдания, чем прежде.

\section{1) página91}

Дорогой Лев Николаевич, я узнал, что духоборы выселяются и что скоро пойдет из Батума первый пароход. Чувствую себя так, как будто из одной со мной комнаты выезжает мой брат, и поэтому не могу продолжать своей жизни, не обращая внимания на его отъезд, в особенности в таких трудных обстоятельствах. Я сейчас у Вульфов на 15 -ти рублях в месяц, делаю разные дела, варю, убираю, бью плантаж, кошу, вообще всякие дела, но могу все это бросить когда хочу, так как есть в виду хороший человек, который станет на мое место.

Я был бы счастлив, если бы Вы помогли мне быть там (на Кавказе) между ними и сопровождать их до места назначения на пароходе, если там нужен человек. Мне думается, что я там был бы небесполезен, но я не знаю обстоятельств и хотел бы посоветоваться с Вами. А кроме того, у меня средств очень мало, хотя и нужно-то немного.

Я могу (хотя плохо) говорить по-английски, знаю море и портовую жизнь и цены на продовольствие, а главное, чувствую, что моя совесть и все существо требует от меня быть с ними и помочь, если они нуждаются во мне, так как, зная, что они уезжают, очень взволнован.

\section{2) página92}


Я был бы очень рад, если бы вы пристроились к духоборам. Я думаю, что вы были бы им полезны.

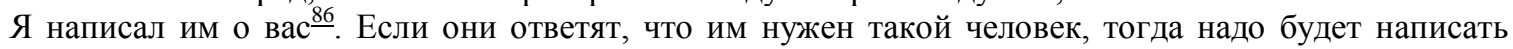
письмо Голицыну, которое вы свезете ему, чтоб он дал позволение вам быть с ними.

\section{3) página92}

- Что касается меня, то я только раз в жизни чувствовал полное удовлетворение своей деятельностью, -- это -- когда я возил переселенцев в Канаду. Вот это было то! Это было настоящее!..

\section{4) página92}

Дорогой Лев Антонович! Мы знаем, что бог создал тебя специально для таких делов, и мы знаем, что ты только единый из наших друзей эти дела можешь делать.

Конечно, ты скажешь что: я не птица, не могу на крыльях перенести и на такое далекое расстояние, как Сибирь, трудно оказать помощь, но все-таки мы надеемся, что примешь на себя труд и сделаешь, что можешь.

\section{5) página93}

Простите, что пишу Вам письмо, я никогда не позволяю себе затруднять Вашего внимания, но раз оно пишется, воспользуюсь им и с другой целью.

Я почти никогда не умею выразить и не выражал Вам той любви и благодарности, которые всегда и беспрерывно испытываю по отношению к Вам за тот свет, который Вы зажгли в моей душе. Без Вас я не знал ничего, было темно, запутанно и часто так тяжело, что не раз был близок к самоубийству. Если я и теперь не лучше, так же гадок и грязен и страдаю от этого, то зато я знаю, что есть свет, который и меня освещает и согревает, и страдания уже не безвыходны, и я могу жить и радоваться чистою хорошею радостью. Могу жить и умирать спокойно, зная, зачем «я». Дорогой Лев Николаевич, я до слез взволнован, пиша эти строки, так как очень, очень люблю Вас и не могу всего этого сказать и не сумею никогда этого сделать. Это и нельзя сказать. Вы мне дали жизнь. Простите, милый, дорогой. Я всегда живу с Вами, где бы я ни был. Всем Вашим мой сердечный, самый сердечный привет. Я всех вас крепко, крепко люблю.

\section{Л. Сулержицикий}

\section{6) página 93}

Десять лет тому назад мы сидели вокруг стола в классе на уроке Сулержицкого.

Школьная сцена слабо освещена.

В самой зале полумрак.

Леопольд Антонович тихо о чем-то рассказывает.

Вдруг заходит Адашев.

— Господа, Толстой исчез из Ясной Поляны.

В груди что-то колыхнулось.

Мы ничего не поняли. Сулержицкий привстал. Мы смотрим на него. Тишина.

Лицо Сулержицкого озаряется - он понял.

- Ах, Лев Николаевич, как это хорошо! Как это великолепно. Наконец-то, - сказал он в тишине восторженно.

Мы все молча встали.

Стояли долго.

И молчание было долгое, насыщенное, торжественное и страшное...

\section{7) página 94-7}

\section{Схоронил Толстого.}

Последний раз по знакомой мне дороге, между березовыми рощами, прошел я с ним от станции до дому.

Вот тут, на перекрестке дороги и Тульского шоссе, я помню, у него заупрямилась лошадь, на которой он ехал верхом, и мы переменились лошадьми. Там, на мостике, помню, вечером, разговаривали о Чехове и Горьком; было тихо, спускалась ночь, и в избах яснополянских крестьян зажигались огни, а в узкой канавке тускло светилась вода, отражая вечернее небо; было тихо, 
безлюдно.

Теперь тут стоял синематограф и трещал, снимал гроб, в котором его несли крестьяне, гудел сотенный хор «вечную память», и над густой черной толпой видна была палка с платком, которой махал дирижер.

Студенты, курсистки, представители, делегаты в черных пальто с барашковыми воротниками, делающими так похожими их всех друг на друга, десятитысячной толпой растянулись по дороге. Те же распорядители, кричащие «шире, шире», как всегда бывает на похоронах видных деятелей, фотографы, кинематографы и скачущие по бокам казаки и стражники, мелькающие между березами серыми шинелями.

Необычна только кучка желтых полушубков среди черной толпы, несущих гроб и идущих частью впереди гроба. Да еще отсутствие попов, кадила и прочих атрибутов.

Толпа мне не мешала, но, по-моему, нигде она не была так чужда тому, кого хоронят толпой, как Толстому. Так мне казалось.

За гробом, сжатые толпой, шли его друзья, тоже в черных пальто с барашковыми воротниками, - все мы, с разных концов земли собрались, уже старые, с проседью, с морщинами, и мне казалось, что эта черная река с колыхающимся над ней желтым гробом есть сама жизнь, текущая как река, захватившая и нас своим течением и заставившая своей могучей силой идти вместе с ней, по ее течению, туда, куда ей надо.

Вспомнилась вся наша молодость, все наши порывы, труды, даже жертвы и как все это было сломано и унесено потоком жизни - все наши попытки идти против ее течения. Как все ослабели, сдали, сломались, и несемся черными обломками, куда нас несет. И только он один до конца жизни все сильнее и сильнее шел вперед и вперед всей силой души своей. И только мертвый возвращается назад, отдав жизни свое тело, которое не могло поспеть за духом, который потому и оставил тело.

Помню, как давно он как-то говорил про свое тело: «Насел на меня этот Лев Николаевич и не пускает никуда; ужасно надоел этот сосед».

Принесли его в дом и поставили в той комнате, где он едва не повесился на перекладине между шкапами во время своего душевного перелома.

Теперь то, что было Л. Н., или то, в чем был Л. Н., лежало тихо, и мимо него шли тысячи людей и земным поклоном прощались с ним, проходя длинной вереницей из одной двери в другую. Я все время стоял у гроба и не мог оторваться от этого дорогого лба, доброго, скрытого при жизни усами рта, от знакомой руки, на которой я знал каждый ноготь.

«Великий» - так все время чувствовалось, еще больше, чем это чувствовалось при жизни. Но когда я вспомнил, как он любил шутки, песни, как он хохотал, заложив руку за пояс, детским смехом, - передо мной выплывал другой, какого знал только я и немногие. И как было больно потерять этого.

Великий остался и останется навсегда, а потому он не утерян, не ушел, но того, доброго, друга, ласкового и нежного, кроткого и терпеливого, уже нет и не будет.

Того, кто страдал, кто плакал навзрыд, закрыв лицо руками, как ребенок, от душевной боли и оскорблений, которые он перенес у себя дома от близких людей на восемьдесят третьем году, того уже нет. Нельзя его ни приласкать, ни пожалеть, ни утешить, ни успокоить.

Он хотел уйти тихо, незаметно, никого не беспокоя, выйти хоть под конец жизни из ненавистных для его совести условий, а пришлось ему бежать ночью, в темноте, с одним верным человеком, бежать неизвестно куда, по тряской дороге, под дождем, куда глаза глядят.

Какое ужасное одиночество! Приехать на станцию и не знать, иуда дальше ехать. Человек, завоевавший весь мир, 83-летний старик, сидит ночью на глухом, вонючем полустанке и думает, куда бежать - на юг, на север, на восток или на запад? И бежит дальше с первым поездом, надеясь по пути обсудить, где ему искать приюта.

Если его не сумели полюбить и уберечь, - что же тогда можно делать?

И все мы прозевали этот момент, потому что не так любили, как надо было его любить. Слишком мы видели в нем «великого» я забыли старика, нуждающегося и в ласке, и в любви, и во внимании.

И когда все это вспоминал, так было больно, стыдно, так было горько за это.

Теперь мы все собрались вокруг него, все приехали и смотрим растерянно, и теперь мы ему уже не нужны. Поздно.

Я нашел книжку, на которой он написал: «Л. Сулержицкому в знак дружбы — Толстой».

А я даже забыл, что была такая книжка, что была такая надпись. Я помнил только «великого» и совсем забыл того, кто был другом!

Между громадными деревьями мужики вырыли глубокую яму, так в полуверсте от дому. Здесь старик, когда еще был мальчиком, играл с братом Николенькой, которого он считал одним из 
замечательных людей. Николай взял зеленую палочку, вырезал на ней знаки какие-то, по которым на земле стало бы все счастливо, люди полюбили бы друг друга и прошло бы все горе человеческое, и они закопали эту палочку тут, с тем, что когда эту палочку откопают, то все так и сбудется на земле.

«Когда умру, надо будет где-нибудь закопать меня, так закопайте меня тут, где эта зеленая палочка, в память моего брата Николеньки». Так говорил Лев Николаевич, гуляя возле этих деревьев.

Сюда и опустили гроб. Скоро засыпали землей, вырос холм, тысячная толпа молча стояла на коленях. Потом положили венки, живые, железные, лавровые. Толпились. В лесу стало темнеть. Толпа ушла из тишины туда, откуда пришла, — в город, с трамваями, фабриками, заводами, и стало тихо. Лес почернел, светились только вверху клочки неба и вечным шумом шептались верхушки деревьев.

В темноте белели ленты на могиле, такие непонятные в этом диком, густом лесу.

Когда последние черные фигуры с барашковыми воротниками ушли, стало видно, что могила окружена цепью верховых казаков и стражников. Все стояли недвижно, вдалеке, плотным, молчаливым кольцом. Послышался короткий говор, и вдруг раздался дружный крик из сотен грудей:

- Рады стараться, ваше высокоблагородие! - и пронесся диким эхом по роще, так что казалось - все деревья разом вздрогнули от этого крика.

«Домо-ой!» - протянул голос. Послышался стук копыт, лязг оружия, и через несколько минут все стало тихо.

Совсем стемнело, наступила ночь со своими шелестами и вздохами. Возле могилы загорелся костер, и стало видно двух мужиков - старика и молодого, оставшихся здесь ночевать.

Теперь уже совсем тихо. Эти не побеспокоят. Они такие же, как эти деревья, как сама ночь, накрывшая весь мир своим черным тихим пологом.

Я пошел к дому, по дороге нагнал несколько дам, ковыляющих на высоких каблуках по мерзлой, кочковатой земле, заблудившихся между деревьями, которые он сам когда-то насадил.

473 В доме горели все окна. В зале длинный стол, как всегда. Его кресло, в котором он любил сидеть, его портреты, знакомые лица за столом, знакомый говор... Но сидят не так, говорят не так, как сидели и говорили, когда он был тут.

Я обошел все комнаты, осмотрел все углы, посидел в его кресле. Так и казалось, что сейчас войдет он.

Все старые, бывшие друзья собрались вместе и тихо вспоминали о нем и решили, что каждый год 7 ноября мы будем собираться в его память у Александры Львовны.

Потом я уехал в двенадцать часов ночи, как обыкновенно уезжал раньше. Но мне казалось, что больше я уже сюда не приеду.

\section{8) página98}

Актер избавился от презрения очень недавно, и то очень небольшая часть, а до того, чтобы он дошел до положения жреца, а театр до положения храма, надо еще очень и очень много сделать, о чем речь впереди...

\section{9) Página 99}

Каким образом поддержать художественность исполнения пьесы, идущей так много раз, как «Синяя птица»?

Надо подумать об этом, надо выработать какие-нибудь способы, которыми можно было бы поддерживать художественность исполнения пьесы - это необходимо - это вопрос первейшей важности и не терпящий отлагательства. Это, по-моему, вопрос не частный, - это вопрос будущности Художественного театра и даже, может быть, его существования.

Слава, имя, значительность МХТ завоеваны страшной борьбой - они дались не сразу — на это надо было время. Когда работали над МХТ - вряд ли ожидали, что маленькая группа лиц, работавших в Пушкине, в сарае, игравших в Охотничьем клубе, - что театр этот впоследствии будет иметь такое значение в истории русского и иностранного искусства, что он вырастет в громадное учреждение в четыреста человек, с полумиллионным оборотом.

Это пришло незаметно. Пришло как результат. То, что происходит теперь, так же незаметно может привести к другим результатам. На это тоже нужно время. 
Для нас двадцатый, тридцатый, пятидесятый спектакль как будто бы не важен - для нас это только «работа», почти отбывание воинской повинности. А между тем именно эти спектакли смотрит Россия. Ведь не московская же публика дает 78 сборов. Кроме того, постом смотрят провинциальные актеры, режиссеры, антрепренеры.

А что мы даем?

За немногими исключениями (почему-то выпадающими на маленькие роли) актеры от спектакля к спектаклю мало-помалу становятся не «творцами», а «докладчиками» роли, как определяет такой род исполнения Константин Сергеевич.

И должен сказать - очень плохими докладчиками. Этого мы не умеем. Слова летят с невероятной скоростью, я слышу только начало фраз и в подавляющем большинстве случаев не слышу конца их. Реплики хватаются раньше окончания предыдущих слов; переходы делаются раньше, чем случилось то, что должно вызвать тот или другой переход (Е. П. Муратова, С. Л. Кузнецов, Н. Ф. Балиев в «Ночи»). Роли теряют рисунок и расплываются в каком-то кисло-

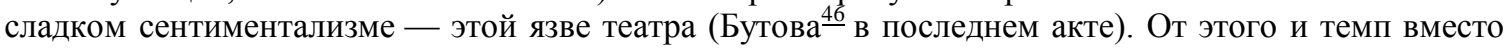
бодрого, живого получается затяжной, нудный.

В ролях появляются пустые места, в содержании которых актер не дает себе отчета, - они звучат бессмысленно, и от пустоты этих мест бледнеют и соседние с ними (Коновалов, Коренева- и многие другие).

Наряду с невероятно дешевым пафосом появляются какие-то необыкновенно мистическитаинственные интонации, совершенно необъяснимые по своему происхождению. Целые роли ведутся уже на голом театральном подъеме, в котором нет возможности доискаться какого бы то ни было смысла.

Вообще, чтобы выразить одним словом, - отличительной чертой исполнения пятидесятых спектаклей, как это ни странно прозвучит, является поразительное отсутствие содержания, «Макаров-Землянский», как говорит Константин Сергеевич. Скучно, нудно, не нужно все это.

Выручает гипноз: «Московский Художественный театр».

Надолго ли его хватит?

Все это убожество исполнения всей своею тяжестью ложится на белую чайку, прикованную к серому занавесу.

Не слишком ли большую тяжесть взваливаем мы на ее прекрасные, но хрупкие крылья? Не улетела бы она от нас — она ведь вольная птица.

Я позволил себе резко говорить об исполнении только потому, что видел и знаю настоящее, художественное исполнение этих же лиц и даже в этих же ролях, и потому мой долг сказать вам об этом - как понимаю. Я говорю сейчас не как режиссер пьесы, а как товарищ по делу, как лицо, уважающее этот театр.

То, что театр может ставить в течение сезона одну и ту же пьесу по 78 раз, - в этом спасение театра, но в этом, возможно, и опасность его погибели, если не разрешить вопроса о сохранении художественности на все 78 спектаклей.

Если сказать (обычное возражение), что нельзя 78 раз жить ролью, то это не будет исчерпывать вопроса. Почему же, например, Халютина, Коонен, Карцев ${ }^{48}$ и некоторые другие сохранили рисунок роли на все 78 спектаклей, а другие, как, например, Коновалов, растеривают понемногу роль?

Почему у Н. Ф. Балиева в том или ином направлении, но развивается роль, становится все крепче и интереснее, а у опытной актрисы разжижается и бледнеет? Почему после первых же спектаклей режиссерские замечания почти не принимаются актерами?

Все эти и многие еще «почему» надо обсудить, обдумать, найти на них ответы. Пока этого не будет сделано - опасность неминуема.

Извиняюсь, я далеко не исчерпал темы, назвал только некоторые имена как в положительной, так и отрицательной стороне дела, но я хотел только иллюстрировать свои положения и не собирался делать оценки отдельным исполнителям. Надеюсь, это мне простят. Я хотел только обратить внимание на серьезность положения.

Я лично далеко не уверен в такой уж несомненной необходимости существования театров вообще - театр не составляет в моей жизни альфы и омеги, - поэтому хочу указать еще на одну сторону дела, хотя, может быть, вы и сами обратили на нее внимание.

Вспомните, чего стоит постановка такой пьесы, скажем, как «Синяя птица»?

Сколько нервов режиссеров и актеров, сколько труда, порой насилия и даже жестокости выпадает на долю людей, создающих пьесу с другого ее конца, со стороны красок, холста, вообе ее материального воплощения?

Люди по ночам строгают в холодной мастерской, что-то паяют, куют в чаду горна, техники портят себе глаза на всю жизнь, работая при фонарях, маляры чахнут в душном воздухе мастерской, 
вдыхая пыль ядовитых красок, портные, бутафоры, лепщики - целая армия людей, которые, хотя и не посвящены в художественный замысел целого, отдают свои жизни для создания пьесы. Пьесы, которая через несколько спектаклей, показанных людям, в сущности мало в них нуждающимся (первые абонементы), становится пустым звуком, «кимвалом бряцающим».

Мы платим всем рабочим. Об этом не стоит говорить, - здесь не место. Одно только очевидно, - никто из нас с ними добровольно местами не поменяется. А потому, если мы уже пользуемся этой несправедливостью, то должны иметь на это хотя бы некоторое нравственное право, которое возникает только для художника, отдающего всего себя искусству.

А иначе - это ремесло, «хорошо оборудованное дело на полном ходу».

Очень хорошо оборудованное.

Все идет чисто. Ходят надсмотрщики - от дирекции: Сулержицкий, Александров, Мчеделов; ходит надсмотрщик от труппы: Леонидов, - все приведено в порядок. И правда - смеха, балаганства на сцене нет, все вовремя на местах, а если какой-нибудь фонарь, освещающий внутренность очага, замигает, то это преступление уже занесено в протокол, - сделано три выговора - интеллигентный, домашний и неинтеллигентный, — виновный наказан.

Но и это теперь бывает редко... Все в порядке, - музыка играет, черный бархат опускается, поднимается, хромотропы мелькают, актеры говорят, кричат, машут руками...

Фабрика в полном ходу.

Разве это не страшно? Для чего все это?

Где жизнь? Как ее вернуть? Как удержать?

\section{0) página101}

Протокол прекрасно выражает мои муки и опасения. Очень будет жаль, если товарищи отнесутся к этому протоколу холодно или недружелюбно. Желательно, чтобы каждый серьезно вник в смысл и повод, заставивший с такой горячностью писать эти страницы. Было бы ошибкой думать, что этот протокол преувеличение... На моих глазах совершилось то, чего боится Лев Антонович. Во времена Шумских и Медведевых ${ }^{49}$ не бывало случаев, чтобы пьеса разлаживалась. После них пьесы были свежи два-три спектакля. А теперь... И все это случилось с седовласым могиканом, создавшим русское искусство - в период десяти-пятнадцати лет. И странно... Лев Антонович ни одним словом не упрекает в нерадении, в отсутствии дисциплины, в нежелании. Напротив. Значит, кроме дисциплины и порядка есть что-то другое, что может подтачивать художественное дело.

\section{1) página102}

С тан и сл а в к и й: А к чему слова? Без слов можно тоньше передавать разные чувства. Например, какая актриса передавала на сцене более точные чувства, чем Дункан? Если сравнить: Дункан и Дузе, то я предпочту Дункан. Театр должен дойти до этого искусства, так развить его, чтобы без слов все передавать.

С улер жицкий : Это совершенно неверно. Театр драмы есть тот род сценического искусства, средства которого есть не только чувства, но и мысли, идеи; а где привходят мысли, где актер должен заряжать публику, воспроизводить не только чувства, но и мысли, там слово необходимо, а кроме того, слова сами по себе, помимо того, что они служат наряду с другими вспомоществующими им способами выразителями мысли, идеи, - они в то же время обладают способностью быть красивыми - можно ими воспользоваться как предметом искусства, как это в поэзии. У них есть своя музыка, ритм, стиль языка автора и т. д., не говоря уже о голосе, этом тончайшем материале для искусства. Слова грубы со сцены - в этом виноваты вы, люди театра, а не самое слово. Это значит, что вы еще не нашли способа произносить слова, выражать чувства и мысли словами.

\section{2) página102}

El actor tiene muy abandonada la palabra. Hay que aprender a hacer llegar la palabra, 'servirla' al publico. Si se traduce al lenguaje teórico, hay que decir que en la base de toda educación del actor falta vaciar en los moldes de la palabra todo aquello que llamamos vivencias.

\section{3) página103}

Слова мешают выражать чувство или идею - это все равно, что Дункан сказала бы: танцыь, жесть 
ногами в балете мешают мне передавать свои ощущения, и потому отказаться от жестов и поз. Однако она этого не сделала, потому что именно это и есть предмет ее искусства. Она отказалась от «таких жестов» и нашла новые, свои, нашла новый способ жеста и движений. Она изучала жест и позу у Боттичелли, в древней скульптуре и т. д., и нашла

\section{4) página104}

Сулержицкий же придавал «системе» более универсальное и более радикальное миротворческое, можно сказать, значение: «система» становилась для него орудием нравственного самоусовершенствования всех, кого объединяет Студия, и не столько даже на сцене, сколько в жизни.

\section{5) página104}

Такой усиленный нажим на этику был для Сулержицкого не только естественен, но и даже неизбежен. Известна его стойкая приверженность к толстовству, к толстовским идеям непротивления злу, к исповедуемой Толстым вере в природную честность и доброту человека, искаженную цивилизацией, в необходимость «опрощения». Правда, этическое миссионерство Сулера было абсолютно лишено фанатизма и сектантской нетерпимости. Напротив, это был светлый, легкий, чистосердечный, неотразимо обаятельный человек (в конце концов даже Немирович проникся к нему доверием). И все-таки восприятие Сулером «системы», в которую он глубоко уверовал и которую горячо пропагандировал, отнюдь не полностью совпадало с основными целями Станиславского.

\section{6) página105}

И в его грезах о высшей театральной форме все чаще и чаще мелькал образ особенно чистой, напряженнейшей организации: коммуны актеров, актеров в том смысле, как это слово понимал Сулержицкий.

\section{7) página105}

Идея была одна-единственная, определенная и ясная: воспитание актера, экспериментальная проверка приемов «системы», ее совершенствование. В частности, занимала его перспектива актерских импровизаций, причем Станиславский специально пояснял, что вовсе не имеет в виду «задачи исторического воскрешения commedia dell'arte», нет, говорил он, «мы хотим разработать процесс “переживания” в импровизации»

\section{8) página105}

Когда Сулержицкий умер, гроб с его телом стоял в нашей студии.

После похорон, на гражданской панихиде, среди говоривших о нем выступил и Станиславский. Он был бледен, и губы его дрожали.

Речи своей он не кончил и, сдерживая рыдания, ушел за кулисы нашей маленькой сцены.

\section{9) página107}

Очень рад, что наша система проникает в недра Художественного театра; ради бога, займитесь педагогикой, у Вас к ней большие способности. Вы не можете себе представить, какую пользу Вы принесете Художественному театру и как это крепко свяжет Вас с ним.

\section{0)}

\section{página108}

В студии Сулер или Вахтангов дают тему импровизации, назначают время. Полчаса или сорок минут живите в предлагаемых вам обстоятельствах. Вы - Робинзоны, выброшенные на морской берег. Пираты, нашедшие сундук с золотом. Хозяева, работники, заказчики по шляпной или портняжной мастерской. Или сапожной. Или похоронного заведения. Будьте свободны, здоровы, веселы, собираясь вместе. С утра посмотритесь в зеркало, сделайте зарядку-упражнения. В комнатестудии я- это я. Свободный, легкий, готовый импровизировать - где? - В портняжной мастерской. - С кем? - Со стариком портным, всю жизнь сидящим, с иглой-нитью, с ножницами, над куском новой материи или над распоротым пальто. Хозяином (хозяйкой), старшей мастерицей, девчонкой, отданной в ученье. Всем, кто здесь, - заняться делом. Кстати, можно упражняться с 
невидимыми вещами. Гладить несуществующим утюгом — так, чтоб зритель поверил в его тяжесть, раскаленность, в то, что вы обожгли палец, или вдевать невидимую нитку в несуществующую иглу - номер, известный с тех пор, как появились нитка с иголкой. Тут же питье из призрачного стакана, поедание несуществующего яблока, или апельсина, или обжигающей похлебки - как бы ложкой из как бы миски.

101)

página109

Режиссеру надо гореть образами, пьесой, но быть терпеливым и помнить, что прежде всего он зеркало - в этом главное его назначение, а вся его насыщенность образами, увлечение пьесой, творческий запал - не более как амальгама, благодаря которой он может быть зеркалом, а не пустым стеклом, которое ничего не может отразить и потому бесполезно.

102)

\section{página110}

(...) observar y dirigir la voluntad del actor, sin que esté consciente de esto; y ser capaz de imitarlo sin causarle huillacion, sino con amor y amistad (...) de tal modo que el actor pueda verse cara a cara, como un espejo.

103)

\section{página110}

Из воспоминаний Алексея Дикого: «Как-то особенно ясно помню на репетициях "Надежды" Леопольда Антоновича Сулержицкого. Он тоже был предельно тактичен с Болеславским, стараясь нигде и ни в чем не ущемлять его молодого самолюбия. Да и метод Сулержицкого был таков, что казался формой невмешательства в область собственно режиссуры. Сулержицкий не был постановщиком в принятом смысле слова, хотя и начал свою “жизнь в искусстве” в эпоху усиленного искания театральных форм. Его влияние на спектакль осуществлялось путем духовного “подсказа", через цепь бесед по ролям и всему спектаклю, бесед не “литературных", но театрально действенных, сочетавших творческий “подсказ” с показом. Он был в первую очередь толкователь драматургического материала, толкователь отличный, тонкий. Не являясь режиссером-философом, как Владимир Иванович, он обладал не меньшей чем тот интуицией, и благородство его души накладывало свой отпечаток на каждый спектакль, с которым ему приходилось соприкасаться. Я думаю, что чистота атмосферы "Надежды” была в большой степени отражением личности этого прекрасного человека.

\section{4)}

\section{página112}

Он умел серьезно говорить. И его слова были тем более убедительны, что он говорил о многом не понаслышке, а по собственному тяжелому или радостному опыту. Да, ему было о чем рассказать, чего не прочтешь в книгах. Ему было о чем говорить, так как у него были мысли и идеи, которые он выстрадал. Ему было что проповедовать, так как у него были цели, ради которых он жил. Ему было о чем мечтать, так как он всегда искал лучшего и более возвышенного.

\section{5)}

\section{página112}

Сулер принес с собой в театр огромный багаж свежего, живого духовного материала, прямо от земли. Он собирал его по всей России, которую он исходил вдоль и поперек, с котомкой за плечами; по всем морям, которые он переплыл не раз, по всем странам, которые он посетил во время своих кругосветных и иных путешествий $\frac{394}{2}$.

Он принес на сцену настоящую поэзию прерий, деревни, лесов и природы, художественные и жизненные наблюдения, выстраданные мысли и цели, оригинальные философские, этические и религиозные взгляды.

Он принес девственно-чистое отношение к искусству, при полном неведении его старых, изношенных и захватанных актерских приемов ремесла, с их штампами и трафаретами, с их красивостью вместо красоты, с их напряжением вместо темперамента, с сентиментальностью вместо лиризма, с вычурной читкой вместо настоящего пафоса возвышенного чувства.

Сулер принес с собой широкое, свободное отношение к искусству (...) 
106)

página113

"I say: we take the fish and God take us."

107)

página114

Сулер передавал студийцам свою память ночных вахт, управления штурвалом, шелеста парусов, свиста ветра в снастях, передавал так естественно-незаметно, что студийцам казалось сами все помнят, знают, воскрешают на сцене.

Театральная жалость: «Ах, бедные матросики» - не проникала в работу. Каждый находил в своем образе себя, обращался к своей аффективной памяти, в которой были расставания, тревоги за близких, новые встречи.

108)

página115

Сулер был хорошим педагогом. Он лучше меня умел объяснить то, что мне подсказывал мой артистический опыт. Сулер любил молодежь, и сам был юн душой. Он умел разговаривать с учениками, не пугая их опасными в искусстве научными мудростями. Это сделало из него отличного проводника так называемой «системы», он вырастил маленькую группу учеников на новых принципах преподавания. Эта группа вошла в ядро Первой студии, которую мы вместе учреждали. Этому делу он отдал свои последние административные, творческие, педагогические, нравственные силы. Здесь, в этих стенах, он оставил большой кусок своего сердца.

109)

página115

Во время работы над «Сверчком на печи» Леопольд Антонович (как художественный руководитель он принимал участие во всех постановках) раскрыл для нас душу этого произведения Диккенса. Как он делал это? Не речами, не объяснениями, не трактовкой пьесы, но тем, что сам на время работы превращался в диккенсовский тип, собственно, в Калеба Племмера, игрушечного мастера.

Не думаю, чтобы он сознавал эту перемену в себе. Она произошла в нем сама собой, правдиво и естественно, как и все хорошее, что он делал.

Его присутствие на репетициях создавало ту атмосферу, которая так сильно передавалась потом публике и в значительной мере содействовала успеху спектакля.

110)

página117- 118

Wilhelm (shrieking) - Be still, I tell you!

Auguste (turning her back to him) - Oh well, you're just in love, that's all.

Wilhelm (seizing Auguste roughly by the shoulder) - See here, woman, I -

Robert (seizing Wilhelm's arm, speaks coldly, bringing each word out distinctly) -

Wilhelm, are you going to do the same thing again?

Wilhelm - The devil!

Auguste - Have you got anything to say? You? Who raised your hand against your own father?

Dr. Scholz (in a voice trembling with anger, in a tone of absolute comand) - Auguste! Leave the room! this minute!

Auguste - Well now, I'd like to know -

Dr. Scholz - You will leave the room this minute!

Frau Scholz. - Oh, my good Lord, why don't you take me to yourself? (In a half-weeping tone.) Auguste! Do you hear! Obey your father!

Robert - Why, mother! She shouldn't do anything of the sort. She's no child any longer. Times have changed by the Lord they have!

Dr. Scholz - But I haven't changed. I'm the master in this house. I'll show you that! Robert - Ridiculous!

Dr. Scholz (shrieking) - Rob - ber and mur - derer! I - disinherit you! I'll throw you out in the street.

Robert - This is simply comical.

Dr. Scholz (conquers a fearful outburst of anger, and speaks with ominous calmness and firmness). - You or I, one of us leaves the house this moment.

Robert - I, of course, and I shall be very glad to do so.

Frau Scholz (half commanding, half entreating) - Robert, you must stay.

Dr. Scholz - He goes. 
Frau Scholz - Fritz! Listen to me! He is the only one - in the long, long years he hasn't forgotten us, he Dr Scholz - He or I -

Frau Scholz - Give up this time, Fritz, for my sake!

Dr. Scholz - Stop that! He or I! Frau Scholz - Oh, you needn't have anything to do with each other, as far as I'm concerned, it can be arranged all right - but -

Dr. Scholz - Very well, I give in. I give in to you and your pack. You and your pack, you've won the victory for good!

Wilhelm - Don't go, father! Or if you do go, let me go with you this time!

Dr Scholz (drawing back involuntarily, between anger and horror) - Don't bother me, vagabonds! (Hunting blindly for his effects) Thieves and loafers, wretched vagabonds! Wilhelm (with an outburst of indignation) - Father! And you darecall us that! And it was you who made us that No, no, father, I didn't mean to say that! Let me go with you, I will stay with you, let me make up for all I have - ( He has laid his hand, on his father's arm)

Dr. Scholz (as if paralyzed with horror and disgust, draws heavily away) - Let me loose! I tell you - the schemes of my persecutors are going to come to - I'm sure - to come to grief. Are these the people, these mighty folks - and are these mighty folks men? A man like me, who is partly to blame, but anyway is entirely - and - through and through, and short and simple -

Wilhelm - Father! Father! Oh, my dear father! Try to collect yourself, try to think where you are!

Dr. Scholz (swaying to the rhytm of the words, softly) - Short and simple - through and through -

Wilnelm (embracing him, in an instinctive effort to stop the motion) - Try, father, try to think!

Dr. Scholz (pushing at him, like a little child) - Oh, don't hit me" Oh, don't punish me! Wilhelm - For God's sake, father!

Dr. Scholz - Don't hit me! Don't hit me again! (He makes convulsive efforts to free himself from Wilhelm's arms)

Wilhelm - May my hand rot off, dear father, you mustn't believe - father, you mustn't think -

(Dr. Scholz frees himself and starts away, followed by Wilhelm)

Wilhelm - Strike me! You strike me!

Dr. Scholz - Please, please, please - help! (Ida appears in the door from the side room, pale as death)

Wilhelm (catches up with his father, embraces him anew) - Oh, you strike me!

Dr. Scholz (in Wilhelm's arms, collapses into a chair) - I - ah - ah! - I - think - it's all over - with - me!

Wilhelm - Father!!! (Frau Scholz and Auguste have fallen in terror into each other's arms. Robert, as pale as death, has not moved: but his face bears na expression. Of invincible determination).

\section{1)}

\section{página119}

Когда актер действительно живет глубоко, когда его игра есть «творение», то как бы сильно он ни

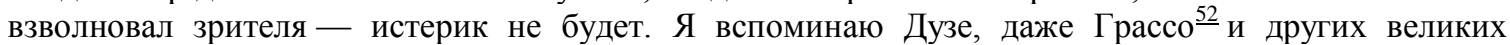
актеров, как Шаляпина, или Никита ${ }^{\frac{53}{}}$, или актеров Художественного театра в лучших ролях и моментах — и не могу вспомнить и даже представить себе, чтобы их искусство вызывало истерики. Наоборот, люди даже с растрепанными нервами и склонные к истерике, поддаваясь их искусству, получат духовное удовлетворение и успокоятся душевно. Они, может быть, будут плакать на спектакле, но это будут совсем другие слезы, - это будут тихие слезы и скромные, не для публики, это будут благородные слезы умиления перед добром и красотой, слезы о несчастиях и горе людей, в том числе, может быть, и о своем горе, поскольку и я человек и подвержен вместе со всеми страданиям, слезы о том, почему мы все несчастны, почему жизнь не прекрасна, почему мы слабы в добре, почему мало любим друг друга и т. д., потому что настоящий талант, настоящее искусство только об этом и говорит.

\section{2)}

\section{Página 120}

Ida (her face is pale, her manner very serious and anxious. She steps softly to Wilhelm, embraces him and presses her cheek against his) - Oh, Willy! Listen: sad days come and then - isn't it so, Willy? Bright days come again. You mustn't let yourself be so - so utterly and completely crushed.

Wilhelm (stammering passionately) - Ida! My only dear! My dearest! Sweet, how can I - how could I even live without you? Your voice, your words, your whole sweet, wonderful self, your hands, your kind, true hands -

Ida - And what about me? Do you think I want to live without you? No, sweetheart! We will put our arms around each other and not let go - tight - tight - and as long as we're like that -

Wilhelm - Yes, yes! But suppose we can't stay so? 
Ida - Oh, don't talk like that!

Wilhelm - I only mean - you can never tell - one of us might die -

Ida - Oh, but we're young.

Wilhelm - That doesn't make any difference. It will have to come at last. I'm sure I'll not live to be very old.

Ida (hotly) - Then I'll put my arms around you, then I'll press up close to you, the I'll go with you.

\section{3)}

\section{página120}

«Не потому они ссорятся, что они дурные люди, а потому мирятся, что они хорошие по существу. Это главное.

\section{4)}

\section{página121}

Давайте всю теплоту, какая есть в вашем сердце, ищите в глазах друг друга поддержки, ласково ободряйте друг друга открывать души.

Только этим, и только этим вы поведете за собой зрительный зал.

Не нужно истерик, гоните их вон, не увлекайтесь эффектом на нервы. Идите к сердцу»

\section{5)}

\section{página121}

— Миша! - услышал я тихий и ласковый голос.

Я обернулся. Около меня стоял Сулержицкий, весь мокрый от проливного дождя. Я остолбенел. Весь день Леопольд Антонович не отходил от призывного пункта и ждал меня в толпе родных, оплакивавших своих единственных... Кто же был я ему, Л. А. Сулержицкому? Брат? Сын? Я был всего только одним из его учеников!!!

\section{6)}

página121-2

Как все истинно добрые люди, Л. А. Сулержицкий любил иногда казаться сердитым, строгим и даже грозным. Он завел в студии толстую книгу, в которую каждый из нас мог заносить свои мысли.

Однажды Леопольд Антонович сам записал в эту книгу ряд удивительных мыслей о рабочих, об их тяжелой жизни в современных условиях и в связи с этим о необходимости внимательного отношения к нашим театральным рабочим. Я, прочитав эту статью, вдохновился ее содержанием, но, увы, не нашел ничего лучшего, как излить свое вдохновение в ряде карикатур, которыми и иллюстрировал статью Л. А. Сулержицкого.

Вечером, придя в студию, я услышал громовой крик. Л. А. Сулержицкий искал виновника иллюстраций и. казалось, готов был растерзать его на месте.

— Это оскорбление! — кричал он издали, приближаясь к нам. — Кто, кто смел сделать это?!

Разгневанный Л. А. Сулержицкий показался в дверях, ища свою жертву.

— Кто сделал это? Говорите сейчас же! Кто?

— Это я... - ответил я в ужасе. Пауза.

- Ну, так что же такого? - ласково и спокойно сказал вдруг Л. А. Сулержицкий. - Ну, нарисовали! Ну и что же? Да ничего!

Леопольд Антонович обнял меня и готов был утешать, как будто виноват был он, а я привлекал ею к ответу. Такова была злопамятность Л. А. Сулержицкого

\section{7)}

\section{página123}

И другой ученик, А. Д. Попов, именно это вспоминает и подчеркивает через много лет в своей книге о театре: «Так же как для Станиславского, для Сулержицкого морально-этический облик человека неразрывно связался с его артистическим обликом. Поэтому он в самом настоящем и глубоком смысле этого слова воспитывал студийцев. Грубость в быту и в повседневной работе он ненавидел со всей присущей ему страстью. Один неэтичный поступок студийца 83 он мог возвести в событие первостепенного значения, от которого, как ему казалось, зависела судьба всей студии. Так и было однажды: один из студийцев позволил себе грубо разговаривать с нашим единственным капельдинером. Сулержицкий отменил репетиции, собрал весь состав студии, и весь день был 
посвящен разбору этого печального инцидента»

118)

página123

Сулержицкий хотел проникнуть к истокам творчества, хотел найти зерно наивного творчества, потому что сам он был глубоко наивен. В том была его первая заповедь актеру при утверждении «установки на творчество». В «системе» много говорилось о вере актера в значение и реальность того, что он делает на сцене. Сулержицкий учил актеров, собравшихся в Первой студии, верить, но распространял эту веру далеко за пределы только сценического учения - учил верить в жизнь.

Поэтому Сулержицкий предпочитал педагогически-режиссерскую работу непосредственной композиции спектакля. Он нежно и внимательно относился к актеру. Этот человек был вполне наивен и потому откровенен в выражении своих взглядов и ощущений.

\section{9)}

página125

Нет дня, нет ни одного дня, чтобы я не вспоминал о Сулере... Верьте, что это так. Я говорю правду

120)

\section{página127}

Надо всем вместе пожить и в природе. Только тогда мы по-настоящему узнаем друг друга, сплотимся в семью и полюбим всех. Купим вместе землю, поедем пахать ее, будем сами строить дома на черный день. Зимой - искусство, летом - природа и земля

\section{1)}

\section{página128}

Летом, в Евпатории, снова собирал около себя старых друзей и студийцев. Там снова раскрывалось все лучшее в людях, там все были дружны и радостны, и веселый Сулер превращал в праздник каждое будничное дело. Радость жизни жила в нем, несмотря на болезнь, затяжную и мучительную. Но все чаще эта радость гасла, ломалась жизнью, которая шла совсем не так, как мечталось.

\section{2)}

página129-31

Я мечтал о таком театре, где все искусство, полное всяких правд, грело бы людей любовью ко всему человеческому, чтобы театр этот поддерживал веру в человека в наше страшное, жестокое время, чтобы самая эта труппа, состоящая из людей, живущих тепло, дружно, в труде и полной свободе, зимой горя в искусстве, летом радостно живя на берегу моря, где все создано своим трудом, возбуждала бы в людях восхищение своей жизнью и искусством.

На втором году, когда все члены студии перегрызлись до безобразия, когда все было полно тлена в студии, я ослабел и хотел отступить. Много бессонных ночей провел я в студии, боясь уходить оттуда не только днем, но и ночью. Но, собрав все силы, я пошел дальше. И был прав. Лучшее взяло верх, и скоро наступил третий год, полный радостей и окрыления.

Все примирились, поверили друг другу, себе и в себя, я видел, как расцветали души, как сиял «Сверчок» зрительный зал дышал умилением от того счастья, которым сияла молодежь. Наступило лето, и часть молодежи поехала на свою землю в Евпаторию. Покупался инвентарь, сами построили себе бараки, ухаживали за общими лошадьми, возили кирпичи, обедали все вместе... Все это еще только намеки, кусочки жизни, не осознанные как следует, но даже в этих черновых набросках столько счастья, веселья, чистоты, свободы.

Студия-театр как театр все больше растет, уже играет в большом театре в Петербурге, учреждение все развивается, все растет в ширину, все шире раздвигает локти, все больше занимает места в публике, в печати. Неизбежно все больше развивается административно-хозяйственная сторона с ее делами. И вот...

И вот началась крупная ошибка моя...

Дела эти всегда самые скверные, но, с другой стороны, дела яти дают всегда тем, кто ими занимается, положение. Невольно создается впечатление, что люди, занимающиеся ими, стоят во главе дела, невольно они себя ощущают хозяевами дела, неизбежно портятся и отходят от главной цели и от главного ядра студии, от товарищей, сплачиваясь в какой-то орган власти, выполняют уже не волю общую, а только свою, все более и более суживая и принижая цели, устраивая уже не то, 
что имелось в виду, когда они назначались, а устраивая то, что практичнее, что осуществимее, что легче устроить. Всякая утопия, мечта отодвигается, и делается «дело», хороню или дурно, — это надо внимательно рассмотреть, чтобы сказать, к чему это приведет; но мечты уже нет. Вся студия уже не живет общей жизнью. Эти три-четыре человека совершенно самостоятельно ведут дело, все остальные совершенно в этом не участвуют, ничего про то, что делается, не знают и не интересуются.

Это большая моя ошибка, — я должен был больше настаивать на том, чтобы все, вся студия принимала участие в ведении дела. Было бы много шуму, споров, но выковывалось бы что-то, что было бы студией.

Когда я увидел свою ошибку, было уже поздно; уже влиять на этих лиц я не мог.

Поняв это, я решил по возможности уравновесить состав совета, дав перевес в сторону идеализма, так как «деловая» сторона была там исключительно сильна и опасна поэтому, в смысле уменьшения целей. Для этого я прибавил в совет: Соловьеву, Федорову, Бирман, Бондырева.

Затем я хотел отойти совсем на время и был убежден, что они выработаются, что ошибка исправится, что «дельцы», которым большое спасибо за работу, непременно - под влиянием таких товарищей, как Соловьева, Федорова, Бирман, - станут не так меркантильны, перестанут вместе с тем чувствовать себя такими «хозяевами» студии, так как я поставил непременным условием, чтобы совет решал дела в своем полном составе.

Кстати сказать, это сознание себя «хозяевами» на некоторых повлияло ужасно - я знал, что это так ужасно влияет, но прозевал опять, и поправить это очень трудно.

Итак, я верил, что таким образом можно исправить мою ошибку. Как раз в это время Вы почувствовали, что в студии неладно, сказали мне, чтобы я помнил, что заведующий я, что студия доверена мне, а не кому-нибудь другому, что я должен стать на своем посту твердо, что я должен прибегнуть к Вашей помощи как к старшему товарищу, должен прибегнуть к Вашему авторитету. Тяжело мне было возвращаться назад, но, к сожалению, я сам видел, что временно я должен вернуться назад, — виноват я сам.

Но когда я попробовал вернуться в прежнее положение, это было уже невозможным - для этого уже нужно было бороться с этой группой. Борьба эта, как всякая борьба, полна всяких дурных, тяжелых чувств, и у меня на это не хватает сил, - главное, очень трудно душевно. Даже для такой прекрасной цели не могу найти в себе сил. Я признался бы в своей ошибке, - я не сумел сорганизовать всю студию. Если бы не эта ошибка, то...

Но так говорят все, кто не может.

По второму году я вижу, как я был и есмь прав, веря в «утопию». Я это видел воочию.

Но вот одна ошибка, и дело стало. Прекрасную молодежь увлечь я смог, но довести не мог, а двум-трем просто испортил в жизни многое, бросив в трудное положение и оставив их одних в опасных, соблазнительных положениях, без помощи более опытного человека. Можно сказать они не маленькие. Да, но фактически три года я их вел, и они шли.

Я слишком рано обрадовался и увлекся успехами, - вечная моя ошибка во всем. Стоило мне увидеть эскиз, набросок осуществления утопии на третьем году, когда все засияло и здесь и в Евпатории, и я уж раскрыл рот и восхищаюсь, вместо того чтобы усилить внимание и работу. духоборы.

У меня выходит только тогда, когда материал исключителен и доходит сам, как, например,

Приходится сознаться - осуществить своей мечты я не смог. Вот предел. Меня совершенно не интересует внешний успех моей работы - успех спектаклей, сборы - бог с ними, — не это меня может волновать и окрылять, а труппа-братия, театр-молитва, актер-священнослужитель. Не хватило меня на это - я должен уйти. Если этого я сделать не мог - это горько. Я пал духом, очень пал. Не держите меня. Если не мог сделать я, то ведь не это важно, все равно это будет, это есть закон жизни человека, и это будет. Я верю глубоко, весь, - рано или поздно, но будет; эта мечта живет у каждого человека, и она будет.

Может быть, даже еще я и увижу, хотя вряд ли. Но это уже другое дело; мне нужно иначе служить - не браться за задачи, которые не по моим силам, а служить своему так, как положено моим силам.

Поймите теперь меня, Константин Сергеевич, что я не могу быть заведующим студией. Быть директором театра мне совсем не свойственно...

Поймите меня, Константин Сергеевич, что теперь, когда мне видно, что сделать этого дела я не могу, служить заведующим в том деле, которому я отдавал всю душу и сердце, мне невозможно - это слишком больно. Отпустите меня; когда я найду, как смогу служить своей вере, - буду работать. Как я ни болен и слаб, но еще я так не опустился, чтобы только зарабатывать «кусок хлеба».

Наступит и этот час, придется его принять, как и смерть, но все-таки чем дальше, тем лучше... 


\section{3)página133}

Милые, милые юноши!

Спасибо вам за ваше внимание, за вашу любовь, за вашу заботу, работу, в частности за альбом, который вы так бережно сработали и прислали мне, который доставил мне радость; а самое большое спасибо за то, что вы есть, по грамматике «суть», такие, какие вы есть.

За то, что вы умеете так нежно и преданно любить то, что кажется вам прекрасным и чистым, возвышенным, за то, что вы сумели сберечь в себе молодость, которой так мало теперь.

Стоим мы или не стоим этой вашей любви и веры, — не важно. Если даже не стоим, — не беда, эта ошибка не страшна, потому что любовь всегда права, потому что она одна есть то, что всегда и везде есть единственная необходимость, единственное, без чего нет жизни и без чего все существование всего живущего - полная и жестокая бессмыслица.

И потому еще не бойтесь ошибок, что любовь всегда приносит больше тому, кто любит, чем тому, кого любят. И кто это поймет, тот всегда будет счастлив.

Вспомните Дон-Кихота и Дульцинею (между прочим, правдами и неправдами, но добейтесь видеть Шаляпина в «Дон-Кихоте»).

Я так написал, как будто наша студия очень плоха и уж наверное не стоит, - но дело в том, что я сам слишком близко к ней стою и потому совсем не судья ей - что она такое. Я так же, как и вы, люблю в ней то, что в ней хорошо.

Пока до свидания. Спешу на репетицию, сын теребит, и очень некогда.

Простите, что не назвал вас по именам-отчествам. Я очень плохо помню эти вещи; но души и чем они живы помню всегда.

Будьте же здоровы и молоды и дальше и верьте только себе во всем хорошем, не меняйте его ни на что.

Простите сентенции, это от старости и болезни.

Извините и почерк, я только что встал от болезни и выхожу всего второй день и еще слаб.

Ваш Л. Сулержищкий.

\section{4)}

\section{página134}

(...) а после он слег в постель для медленного угасания. Лежа он не выпускал из рук дешевого издания Диккенса, точно цепляясь за него, как за последнюю соломинку в искусстве. Мечта о постановке «Колоколов», инсценировку которых решила ставить студия, была последней связью с уходившим от него искусством $\stackrel{395}{\text {. }}$.

Но творческое чувство и мысли уже не повиновались Сулеру, и он беспомощно мял книжку в руках, не находя слов для выражения своих поэтических мечтаний. Наконец, измятая книжка выпала из его слабых рук, и... навсегда порвалась связь с искусством.

\section{5)página 135-6}

Господи, возьми к себе душу усопшего, нашего милого, незабвенного, дорогого Сулера, потому что он умел любить, потому что в жизни среди соблазна, пошлости, животного самоистребления, — он сберег в себе милосердие, продиктовавшее ему перед смертью вот эти кристально чистые слова любви. «Боже мой, как горько, как горячо и тепло я плакал сегодня все утро. Плакал так, что подушка и руки были мокрые от слез. Отчего? Оттого, что есть дети, много детей на улицах с худенькими, как палочки, грязными руками, оттого, что они ночью на большой площади, под холодными электрическими фонарями бегают по трамваям и продают газету - “Копейку”, и бранятся и скверно ругаются; оттого, что городовой их гоняет, и мне его за это жалко; оттого, что такая бесконечная тьма новорожденных в воспитательном доме с худенькими, сморщенными, старческими личиками, с бледными, едва ворочающимися пальчиками, лежат рядами, одинокие, на столах, с пришитыми номерками на них и жадно ловят воздух, голодные кричат до изнеможения, затихают, и сохнут, и умирают, глядя в пустоту, отыскивая в этой пустоте умирающими глазами любви и с тоской по ней умирают одинокими в мокрых, холодных пеленках.

Оттого, что служанки там уже не чувствуют этого моря страданий, в котором они полощут белье, и ходят не как в храме, а как на фабрике.

Оттого, оттого, что столько страдания везде, что во всех этих страданиях виноват я, в большинстве из них, оттого, что я это знаю и ничего не делаю, чтобы прекратить эти страдания, оттого, что я всех люблю и могу плакать часами и, главное, оттого плачу, что мало во мне любви ко всем им, так мало любви, что могу жить среди всего этого и заниматься своими делами, так мало веры и знания, что не могу ничего “делать” для них и не делаю!

Господи, дай мне веры или дай такое большое сердце, которое само бы повело, куда надо, и заставило бы жить, как надо!

Господи, дай! Если ты есть» 
126)

página136

Его любовь к студии, то есть к нам, была всепоглощающа.

127)

página136

Случалось, что Сулер сердился, кричал, угрожал, а жесты выдавали его, говоря: «Все вы мне милы, я люблю вас, не бойтесь!

\section{8)}

página 136

Ты ушел от нас, наш прекрасный и благородный учитель. Столько дней подряд мы слышали твой голос, слушали твои мудрые в простые слова, видели тебя здесь, в этом зале, на этих стульях, здесь, на сцене. Каждое слово из наших ролей, каждый предмет наших пьес, каждый закулисный шаг наш воспоминание о тебе. Тебя нет среди нас, но ты в нас настойчиво и требовательно. 